UNIVERSIDADE DE SÃO PAULO

FACULDADE DE FILOSOFIA, LETRAS E CIÊNCIAS HUMANAS

DEPARTAMENTO DE LETRAS CLÁSSICAS E VERNÁCULAS

PROGRAMA DE PÓS-GRADUAÇÃO EM FILOLOGIA E LÍNGUA PORTUGUESA

PRISCILLA DE ALMEIDA NOGUEIRA

\title{
Gramaticalização da construção quase que: motivações cognitivas para o uso da construção de incerteza
}

Versão corrigida 


\section{Gramaticalização da construção quase que: motivações cognitivas para o uso da construção de incerteza}

\section{PRISCILLA DE ALMEIDA NOGUEIRA}

Dissertação de Mestrado, apresentada ao Programa de Filologia e Língua Portuguesa, do Departamento de Letras Clássicas e Vernáculas, da Faculdade de Filosofia, Letras e Ciências Humanas, da Universidade de São Paulo, como exigência parcial para fins de obtenção do título de Mestre.

Orientadora: Profa. Dra. Maria Célia Lima-Hernandes

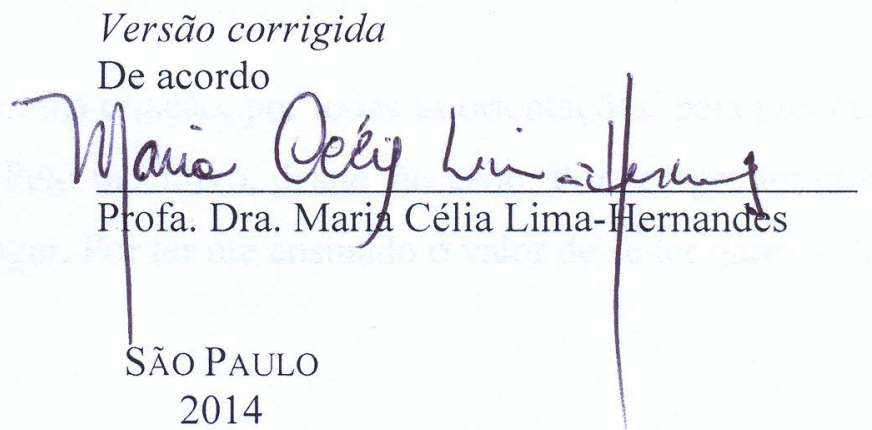


UNIVERSIDADE DE SÃO PAULO

FACULDADE DE FILOSOFIA, LETRAS E CIÊNCIAS HUMANAS

DEPARTAMENTO DE LETRAS CLÁSSICAS E VERNÁCULAS

PROGRAMA DE PÓS-GRADUAÇÃO EM FILOLOGIA E LÍNGUA PORTUGUESA

\section{Gramaticalização da construção quase que: motivações cognitivas para o uso da construção de incerteza}

PRISCILLA DE ALMEIDA NOGUEIRA

Dissertação de Mestrado, apresentada ao Programa de Filologia e Língua Portuguesa, do Departamento de Letras Clássicas e Vernáculas, da Faculdade de Filosofia, Letras e Ciências Humanas, da Universidade de São Paulo, como exigência parcial para fins de obtenção do título de Mestre.

Orientadora: Profa. Dra. Maria Célia Lima-Hernandes

Versão corrigida

De acordo

Profa. Dra. Maria Célia Lima-Hernandes

SÃo PAUlO

2014 


\section{AGRADECIMENTOS}

Agradeço...

À minha orientadora, Profa. Dra. Maria Célia Lima-Hernandes, por toda a dedicação, pelo olhar atento, por ser uma profissional como poucos e uma pessoa maravilhosa. Agradeço imensamente pela oportunidade de ser sua orientanda.

Ao $\mathrm{CNPq}$ e à Fapesp, os quais financiaram durante, respectivamente, dois meses e um ano e dez meses a pesquisa que culminou nesta dissertação de mestrado.

À Profa. Dra. Briseida Dôgo de Resende, cujas orientações relacionadas a uma área ainda tão desconhecida por nós foram essenciais para este trabalho.

Ao Prof. Dr. Paulo Roberto Gonçalves Segundo e à Profa. Dra. Erotilde Goreti Pezatti, pela dedicação à leitura tão atenta de minha dissertação. Ao Prof. Paulo, pelos ricos conselhos, antes e no momento da defesa, que foram de suma importância para o encaminhamento desta pesquisa. À Profa. Erotilde, pelos apontamentos e sugestões, pela valiosa contribuição.

Aos colegas do grupo de pesquisa Linguagem e Cognição, pelas reuniões, pela construção do aprendizado em conjunto, pela companhia nos congressos.

Aos meus amigos e à minha família, pelo apoio, torcida, conselhos. A vida é sempre muito generosa com as pessoas que coloca em meu caminho.

Ao meu pai, Alvaro, por toda minha criação, por todas as orientações, pela preocupação constante com minha carreira. Pelo incentivo, desde tão cedo. Por sempre ter colocado minha educação em primeiro lugar. Por ter me ensinado o valor de se ter garra na vida. 
À minha mãe, Dóris, pelo apoio constante, por toda a preocupação, pelo amor incondicional, por ser a pessoa mais prestativa que conheço, pela simplicidade, que tanto me ensinou.

Aos dois, por todo o amor, por todos os sacrifícios, por nunca pouparem esforços, por colocarem, a mim e a meu irmão, como prioridades em suas vidas.

Ao meu irmão, Gustavo, pelas traduções das citações em língua francesa presentes nesta dissertação, por me ouvir, com tanta paciência, falar sobre meu trabalho, sobre a linguística, sobre toda minha paixão pela pesquisa, por ter contribuído mais do que ele imagina. Que ele saiba que, apesar dos esforços, minha carreira acadêmica jamais será tão brilhante quanto a que ele, tenho certeza, traçará. Ele sabe de todo meu amor por ele.

Ao Leonardo, pelo companheirismo constante, pela preocupação, por sempre acreditar tanto em meu potencial, por não só compreender a importância que dou a minha carreira, como também por me incentivar. Agradeço por sempre torcer por meu sucesso, por ser firme quando estou sem forças, por nunca me deixar desanimar. Pelos abraços, pelo carinho, todos os dias. Pelo incentivo nos dias difíceis e pela alegria compartilhada nos dias de conquistas. Por todo o amor. A vida é sempre mais feliz ao seu lado. 
Com as palavras todo cuidado é pouco, mudam de opinião como as pessoas. Porque as palavras, se não o sabe, movem-se muito, mudam de um dia para o outro, são instáveis como sombras, sombras elas mesmas, que tanto estão como deixaram de estar, bolas de sabão, conchas de que mal se sente a respiração, troncos cortados.

(José Saramago)

O correr da vida embrulha tudo. A vida é assim: esquenta e esfria, aperta e daí afrouxa, sossega e depois desinquieta. O que ela quer da gente é coragem.

(João Guimarães Rosa) 


\section{RESUMO}

Antes que essa dissertação pudesse ser imaginada, já havia um ensaio de dois anos sobre construções de natureza pragmática similar. Referimo-nos às construções meio e meio que. Perguntamo-nos por que indivíduos em situações de alta assertividade lançariam mão de estratégias que soavam tão duvidosas e denunciadoras de incerteza sobre seu estatuto. Esse foi o início do novo percurso com as construções quase e quase que e seu possível processo de gramaticalização. Como professora, o interesse era reconhecer seu estatuto e as formas de abordagem pedagógica de elementos pouco centrais em classes de palavras. Como pesquisadora, o interesse era entender como uma mente fluida deixava escapar essa fluidez de raciocínio por meio de determinadas construções linguísticas. A perspectiva adotada, para esta pesquisa, foi a cognitivofuncional. Realizamos o rastreamento histórico de quase e quase que, recorrendo à composição de uma amostra de obras lexicográficas. Foi assim que identificamos seu traço irrealis, o qual se mostrou essencial para a compreensão das funções assumidas pelas construções em questão e também para entender seu percurso na língua. A hipótese inicial era a de que quase codificaria incerteza, mas as análises conduziram para um novo caminho. Para responder às questões, as quais surgiram ao longo da pesquisa, lidamos com três corpora diversos, além de outras amostras, em momentos oportunos: cartas de leitores e redatores do século XIX; redações dissertativas de candidatos ao vestibular e resumos de teses e dissertações do século XXI. Partimos do pressuposto, neste trabalho, de que cognição, consciência, experiência, cérebro, interação, sociedade e cultura estão intrinsecamente conectados de formas complexas e dinâmicas na linguagem. 


\begin{abstract}
Before this paper could be imagined, there was already a two-year work on constructions with similar pragmatic nature. We refer to the meio and meio que constructions. We wonder why individuals at high assertiveness would launch to strategies that sounded as telltale doubtful and uncertain about their status. That was the beginning of a new journey with the quase and quase que constructions and its possible grammaticalization process. As a teacher, the interest was to recognize their status and forms of pedagogical approach to some central elements of speech. As a researcher, the interest was to understand how a fluid mind let out this fluidity of thought by means of certain linguistic constructions. The perspective adopted for this study was cognitivefunctional. We conducted the historical tracking of quase and quase que constructions, using the composition of a sample of lexicographical works. That was how we identified their irrealis feature, which proved essential for understanding the functions assumed by the constructions and also to understand its course on language. The initial hypothesis was that quase encoded uncertainty, but analyzes have led to a new path. To answer the questions which arose during the research, we deal with three different corpora, and other samples, at appropriate times: letters from readers and writers of the 19th century; dissertative texts of vestibular candidates and abstracts of theses and dissertations of the 21 st century. We assume in this paper that cognition, consciousness, experience, brain, interaction, society and culture are intrinsically connected in complex and dynamic forms in language.
\end{abstract}




\section{Sumário}

$\begin{array}{ll}\text { Apresentação } & 9\end{array}$

$\begin{array}{ll}\text { Introdução } & 20\end{array}$

Capítulo I: Fundamentação Teórica 23

1. O estruturalismo: a língua como estrutura 23

2. O gerativismo: a prevalência do inatismo 24

3. A perspectiva cognitivo-funcional

3.1. Funcionalismo e o ensino da língua 30

4. O conceito de gramaticalização 36

4.1. Gramática de construções 46

4.2. A ritualização 53

5. Cognição 54

5.1. Os princípios de iconicidade e de marcação 55

5.2. A Linguística Cognitiva $\quad 59$

5.2.1. O conhecimento enciclopédico 60

5.2.2. A realidade projetada 61

5.3. Tomasello: o salto qualitativo, a evolução cultural cumulativa e o reconhecimento de intencionalidade 63

5.3.1. O que nos difere? 63

5.3.2. A aquisição de símbolos: o desenvolvimento de habilidades cognitivas e outras consequências 69

5.3.3. A intencionalidade compartilhada 72

6. A Linguística Baseada no Uso 75

7. A categorização e os conceitos de objetividade 78

e (inter)subjetividade

Capítulo II: Encaminhamentos Metodológicos

Capítulo III: Quase e quase que: delimitação do objeto

em sua tradição e inovação

1. A categoria dos advérbios 101

1.1. Ausência de definição que integre 102

todos os membros da classe

1.2. Estrutura de semelhança por familiaridade 103

1.2.1. Graus de representatividade 104

1.2.2. Fronteiras instáveis e pouco nítidas 105

1.3. Ordem e mobilidade 105

2. Rastreando a tradição do uso 108

2.1. A tradição de uso: em busca de sua formação histórica $\quad 115$

2.2. Tradição e seus ecos 118 
1. Panorama de Similaridades e Diferenças 143

2. Recuando no tempo: cartas do século XIX 150

3. Redações vestibulares: um modo abstrato e uma fase de transição 154 3.1. Contexto de emprego das construções nas redações 156 vestibulares

3.2. Amostra de controle: em busca da produção cuidadosa 166 e revisada do uso

3.3. Organização dos padrões do item quase 181

3.3.1. Subprincípio de quantidade $\quad 182$

3.3.2. Subprincípio de distância 184

3.4. Subjetividade Escalar nos usos de Quase e Quase que 186

3.4.1. Usos menos subjetivos 186

3.4.2.Usos subjetivos propriamente ditos $\quad 190$

3.4.3.Usos intersubjetivos 205

4. Dados à parte 207

5. Contabilização linguística 212

Considerações Finais $\quad 216$

Referências Bibliográficas $\quad 228$

TABELA I: Conjunto das redações consideradas piores em cada ano

TABELA II: Conjunto das redações consideradas melhores em cada ano

FIGURA I: Aproximação máxima a uma esfera 184

FIGURA II: Aproximação máxima a um grau de uma escala 184

QUADRO: Abstratização de quase 221

ANEXO I: Exemplário de usos de quase e quase que 239

ANEXO II: Critérios de correção para as dissertações 296 de candidatos ao vestibular da Fuvest 


\section{Apresentação}

Esta dissertação de mestrado toma como ponto de partida os resultados de estudos de iniciação científica desenvolvidos ao longo de dois anos, 2007/2008 e 2008/2009, financiados, inicialmente, pelo CNPq (Conselho Nacional de Pesquisa e Desenvolvimento Tecnológico) e, posteriormente, pela agência de fomento FAPESP (Fundação de Amparo à Pesquisa do Estado de São Paulo) - junto ao Grupo de Pesquisa CNPq/USP então nomeado "Mudança Gramatical do Português (Gramaticalização)". Nesse período, trabalhamos com o processo de gramaticalização do item meio no português culto falado na cidade de São Paulo, a partir da identificação dos deslizamentos funcionais que o tornavam um item cada vez mais abstrato e mais gramatical.

Em estudo-piloto empreendido para identificar as rotas de mudança, tomamos como corpus um conjunto de amostras de língua falada produzidas por informantes contatados na década de 70 do século XX por pesquisadores do Projeto NURC-SP (Norma Urbana Culta de São Paulo) ${ }^{1}$. Os dados extraídos desse corpus foram somados aos da amostra tendência ${ }^{2}$, constituída com amostras de língua falada produzida por informantes de traços sociais similares aos da primeira amostra, porém reunidas em 2012 por pesquisadores do Projeto História do Português Paulista - PHPP ${ }^{3}$. Desses materiais foram identificados treze diferentes padrões funcionais assumidos pelo item meio, que foram, em seguida, elencados, descritos e analisados. Foram aplicados a essa análise o rastreamento histórico do item meio, que havia sido realizado a partir de acepções encontradas em dicionários ${ }^{4}$ dos séculos XVIII, XX e XXI, e o conceito de sequência de categorias cognitivas ${ }^{5}$ proposto por Heine, Claudi e Hünnemeyer (1991), como verificamos com o comportamento dos padrões funcionais a seguir:

\footnotetext{
Amostras da língua falada culta na cidade de São Paulo gravadas no século XX.

2 Segundo orientações labovianas, quando não se consegue o recontato com os informantes entrevistados há muitos anos, com o objetivo de estabelecer um paralelo ou estudo comparativo, é necessário projetar uma nova amostragem com outros informantes que guardem os traços sociais dos informantes da primeira amostra. A esta amostra rotula-se amostra de tendência.

3 Amostras da língua falada culta na cidade de São Paulo colhidas no século XXI.

4 Bluteau (1712 -1728); Dicionário Brasileiro (1975); Novo Aurélio (1999); Houaiss \& Villar (2001).

5 pessoa > objeto > processo > espaço > tempo > qualidade
} 
MEIO 1 - numeral indicativo do que é duas vezes menor que a unidade. Remete às acepções 1 do dicionário Houaiss \& Villar (2001) e 21 do dicionário Novo Aurélio (1999). O dado identificado é associado às categorias cognitivas de pessoa e de espaço.

(1) importou mais de um milhão e MEIO de imigrantes [P.P.]

(2) ele foi direto na estrutura superficial da paisagem e sentiu que existia uma linhazinha de pedra a MEIO metro, um metro e MEIO do solo. [A.A.]

MEIO 2 - substantivo indicativo de posição medial entre dois pontos extremos ocupada no espaço físico por um objeto. Remete às acepções 5 do dicionário Houaiss \& Villar (2001) e 4 do dicionário Novo Aurélio (1999). Preponderantemente associado às categorias cognitivas de objeto e espaço.

(3) Tudo que se referia ao prédio do MEIO foi boicotado pela Diretoria anterior [S.H.]

MEIO 3 - valor indicativo de uma quantidade de tempo duas vezes menor do que aquela expressa pelo substantivo. Remete às acepções 20.1 do dicionário Houaiss \& Villar (2001) e 21 do Novo Aurélio (1999), que não apresenta uma acepção específica para a noção de tempo, como o primeiro dicionário.

(4) acabei fazendo esse projeto e indo para lá para ficar um ano e MEIO [LCML]

(5) nós estamos perdendo tempo há MEIO século praticamente [O.L.C.]

MEIO 4 - substantivo indicativo da segmentação dimensional (geográfica ou quantitativa) de um elemento concreto ou abstrato, também substantivo. Remete às acepções 2 do dicionário Houaiss \& Villar (2001) e 3 do Novo Aurélio (1999). Preponderantemente associado à categoria cognitiva de processo.

(6) No MEIO do caminho, ele parou e me perguntou se eu era vaidoso [A.A.S.]

(7) e não tem sentido ficar, no MEIO de um bate papo, soltando mesóclise. [F.A.]

MEIO 5 - substantivo indicativo da segmentação transversal de um objeto que pode ser empregado como instrumento para uma ação. Remete às acepções 6 e 7 do dicionário Houaiss \& Villar (2001) e 8, 10, 11 e acepção "por meio de" do dicionário Novo Aurélio 
(1999). Preponderantemente associado à categoria cognitiva de instrumento. Alguns usos integram expressões de caráter circunstancial.

(8) a verdade é sempre desvendada por MEIO de uma série coerente de sinais [G.R.M.S.]

(9) Mas com isso nos rouba um MEIO de rejeitar qualquer delas. [M.C.]

MEIO 6 - substantivo indicativo de situação de permeio assumida por um elemento. Preponderantemente associado à categoria cognitiva de espaço. Não se associa às acepções listadas no dicionário Houaiss \& Villar (2001), associando-se à acepção 5 do dicionário Novo Aurélio (1999).

(10) Aqui na Faculdade havia os olheiros do DOPS, infiltrados no MEIO dos alunos [M.C.]

(11) tinha um batalhão do exército impedindo a entrada, então eu não entrei por causa disto daí. Mas se não, estaria lá, e talvez tivesse entrado no MEIO da coisa toda. [M.L.S.]

(12) Esse é um episódio cômico no MEIO de tanta coisa trágica que aconteceu naquele período [A.A.A. $]^{6}$

MEIO 7 - substantivo locativo indicativo da totalidade de um recorte abstrato do espaço físico. Remete às acepções 9 do dicionário Houaiss \& Villar (2001) e 6 e 7 do Novo Aurélio (1999). Preponderantemente associado à categoria cognitiva de espaço.

(13) aquela efervescência política do MEIO universitário [A.V.]

(14) e coincide de eu estar nas universidades americanas, no MEIO acadêmico [E.S.]

MEIO 9 - adjetivo indicativo de uma avaliação imprecisa. Preponderantemente associado, portanto, à categoria cognitiva de qualidade.

(15) a moça que gravou agora parece que ela tem uma mistura, parece que está falando MEIO portunhol [J.M.]

6 Inicialmente, esse exemplo foi considerado ilustrativo de um padrão intermediário, aqui rotulado de MEIO 8 (substantivo indicativo do processo desenvolvido no tempo). Não se associa às acepções listadas no dicionário Houaiss \& Villar (2001) nem no Novo Aurélio (1999). Preponderantemente associado às categorias cognitivas de tempo e de processo. Entretanto, devido ao seu comportamento muito próximo ao exemplo (11), então foram agregados ao padrão 7. 
MEIO 10 - advérbio quantitativo modificador de adjetivos, indicativos de uma avaliação qualitativa. Remete às acepções 24 do dicionário Houaiss \& Villar (2001) e 22 do Novo Aurélio (1999), parafraseável por "um pouco". Preponderantemente associado à categoria cognitiva de qualidade.

(16) Aquilo virou um momento MEIO mágico e MEIO delirante de exercício de liberdade [A.V.]

(17) aqueles versinhos me pareceram mais singelos, mais simples, até MEIO trovadoresco [L.A.M.T.]

MEIO 11 - advérbio modificador de verbos. Não se associa às acepções listadas no dicionário Houaiss \& Villar (2001) ou no Novo Aurélio (1999). Preponderantemente associado à categoria de qualidade, posto que estabelece um valor aproximativo.

(18) era um pianista de primeira, e estava MEIO interrompendo a carreira para se dedicar às letras [L.C.M.L.]

(19) atualmente como todo mundo tem seu disco, até estou MEIO brincando com essa história. [L.A.M.T.]

MEIO 12 - advérbio modificador de advérbios. Funciona sintaticamente como quantificador. Não se associa às acepções listadas no dicionário Houaiss \& Villar (2001) ou no Novo Aurélio (1999). Preponderantemente associado à categoria de qualidade, pois estabelece valores de imprecisão, aproximação ou atenuação.

(20) sabe que a gente quando vai andando um pouquinho, os chips ficam MEIO fora [M.L.S.]

(21) tem a Casa do Japão ali, uma parte vazia aqui em frente, MEIO em frente à História [D.L.P.B.]

(22) eu ouço muita coisa até um pouco, também no mesmo esquema que eu falei pra você, MEIO por obrigação [L.A.M.T.]

(23) porque nós da área de letras, nós tendemos a esquecer isso, nós mesmos achamos, ficamos MEIO numa posição (...) [F.A.]

MEIO 13 - locução de valor discursivo-pragmático composta pelo item sob análise predominantemente seguido da partícula QUE. Não se associa às acepções listadas no 
dicionário Houaiss \& Villar (2001) ou no Novo Aurélio (1999). Sinaliza uma avaliação com certo grau de imprecisão. Funcionaria como um evidencial na situação comunicativa. Preponderantemente associado à categoria cognitiva de qualidade.

(24) A Faculdade estava MEIO QUE dividida entre a união, nas Letras, e a divisão [R.B.]

Após a análise de cada padrão, procedemos à quantificação de ocorrências pertencentes a cada uma das categorias cognitivas, tanto no corpus de contato quanto na amostra tendência. Em seguida, confrontando os resultados obtidos, calculamos as variações percentuais de ocorrência de cada categoria entre esses dois corpora. Verificamos, desse modo, que as categorias [+ concretas], localizadas mais à esquerda da escala (pessoa, objeto, processo), tiveram suas respectivas porcentagens de ocorrência diminuídas, enquanto as categorias [+ abstratas], localizadas mais à direita (espaço, tempo, qualidade), sofreram um aumento de ocorrência. A categoria qualidade foi maioria no corpus constituinte da amostra tendência (55,5\%). Além disso, seu percentual de variação de ocorrência foi o maior $(15,9 \%)$. Tais resultados corroboraram a hipótese do processo de abstratização que teria sido empreendido pelo item meio.

Além de outros métodos funcionalistas de análise de dados, foram checados os estágios $^{7}$ de gramaticalização propostos por Hopper (1991), os quais permitiram identificar a que pressões foi submetido o item meio para que deslizasse funcionalmente. Apesar de ter sido essa análise, na totalidade, a responsável pela explanação e confirmação do hipotetizado processo de gramaticalização do item meio, apresentaremos nesta dissertação apenas parcialmente os resultados os quais atingimos ao aplicarmos o estágio de estratificação, especialmente os que nos motivaram a seguir pesquisando o tema.

Os cinco princípios são empregados como forma de identificar se o item sob análise está, mesmo em estágio incipiente, em processo de gramaticalização. O princípio de estratificação defendido por Hopper (1991) prevê que o analista verifique se cada padrão funcional correspondente a algum uso sinônimo de outra forma no mesmo contexto de emprego. Portanto, para a verificação da ocorrência ou não desse estágio no processo de mudança do item meio, procedemos ao levantamento, utilizando

São eles: estratificação, divergência, especialização, persistência e decategorização. 
mesmo recorte temporal, de termos equivalentes a cada um dos padrões funcionais identificados e descritos. A ocorrência desse estágio foi identificada em quase todos os treze padrões. As exceções foram os dois primeiros, que eram, efetivamente, os menos gramaticalizados. Em todos os outros, havia termos equivalentes sendo empregados pelos falantes pertencentes a um mesmo recorte temporal. Durante a aplicação desse estágio, chamou-nos a atenção a estratificação dos padrões funcionais MEIO 10 (advérbio quantitativo modificador de adjetivo, indicativo de uma avaliação qualitativa), MEIO 11 (advérbio modificador de verbos, que aponta um valor aproximativo), MEIO 12 (advérbio modificador de advérbios, sinalizador de valores de imprecisão, aproximação ou atenuação) e MEIO 13 (locução de valor discursivo-pragmático composta pelo item sob análise predominantemente seguido da partícula QUE e indicadora de uma avaliação com certo grau de imprecisão, funcionando como um modal na situação comunicativa). Neles, o item meio permite estabelecer avaliações de imprecisão, incerteza, atenuação e aproximação. Tais valores, por serem muito próximos, acabam se fundindo, estando frequentemente presentes juntos em uma mesma ocorrência. A seguir, são apresentados exemplos de cada um desses padrões e, em seguida, ocorrências de alguns dos termos que com eles concorrem.

(25) ... era uma perspectiva MEIO dialética... [O.L.C.]

(26) ... atualmente como todo mundo tem seu disco, até estou MEIO brincando com essa história... [L.A.M.T.]

(27) ... tem a Casa do Japão ali, uma parte vazia aqui em frente, MEIO em frente à História... [D.L.P.B.]

(28) ... você fuçava MEIO QUE mergulhado nesse tipo de coisa... [D.L.P.B.]

(29) ... não é como São Paulo, já que é uma cidade UM TANTO QUANTO hostil... [E.P.C.]

(30) ... esse domínio do primeiro mundo, também em termos de ciência, educação e cultura, é QUASE impossível... [O.L.C.]

(31) ... e que talvez tivesse invertido UM POUCO a prioridade... [O. L. C.]

(32) ... era para a gente estar pelo menos igual à Coreia ou UM POUCO para cima... [M.L.S.] 
(33) ... concursos que têm QUASE QUE a incumbência de oferecer um diploma... [O.L.C.]

(34) ... e não se consegue, na verdade, alcançar QUASE QUE matematicamente... [O.L.C.]

(35) ... então eu QUASE QUE ia atrás muito das palestras... [L.A.M.T.]

(36) ... eu foquei ali QUASE QUE involuntariamente... [L.A.M.T.]

Ao longo dessa empreitada de levantamento de termos concorrentes a meio e meio que, foi gritante a alta frequência do item quase e da locução quase que. Surgiu, desse modo, o desejo de dar continuidade ao trabalho desenvolvido no percurso da pesquisa referida. Essa curiosidade motivou-nos a propor um projeto de mestrado sobre o tema, com um recorte na construção de base aproximativa quase que, presente no português do Brasil.

Os contextos linguísticos em que é empregada não parecem diferir dos contextos em que observamos, no estudo anterior, a inserção da construção meio que, entretanto percebíamos uma nuança semântica que necessitava de uma melhor averiguação. Essa diferença de percepção semântica pode ser checada com o seguinte exemplo intuitivo:

(a) Maria anda meio que pensando em se aposentar.

(b) Ando quase que pensando em me aposentar.

(c) Ando quase pensando em me aposentar.

A leitura do exemplo (a) possibilita compreender que Maria não tem a convicção de que seja o momento adequado para sua aposentadoria ou, ainda, que talvez ela não tenha, por enquanto, pensado seriamente em se aposentar, mas que esse tem sido um pensamento que eventualmente passa por sua cabeça.

Com a leitura do exemplo (b), é possível entender que há uma ideia de iminência de que esse momento de pensar em se aposentar se concretize. Parece implicar mais uma decisão ou conclusão, circunstâncias pragmáticas que têm em sua base a iminência. Comparando esses casos com o exemplo (c), notamos uma aproximação com o sentido codificado em (b). No entanto, ainda percebíamos alguma nuança de significação, que precisava ser estudada com dados produzidos em situações reais. 
Em estudo-piloto, empreendido na fase de elaboração do projeto de mestrado, realizamos a análise do conjunto das melhores e piores redações dissertativas de candidatos aos vestibulares da Fuvest (Fundação Universitária para o Vestibular) ${ }^{8}$ referente aos anos de 2004 a 2011. A escolha dessas amostras deu-se em virtude do interesse desta pesquisa pela incorporação de usos inovadores na escrita formal. A própria situação de produção do texto favorece que o padrão culto da língua escrita seja mobilizado para a codificação linguística pelos candidatos. Visando à aprovação no processo vestibular, o escrevente tentará demonstrar sua adesão ao que a banca examinadora - imagina-se - considere "correto" e adequado para a qualidade da dissertação vestibular.

O levantamento de dados realizado nessas amostras, nessa primeira incursão, resultou na identificação de ocorrências da construção quase (que). Abaixo, são apresentados alguns dos exemplos identificados:

(37) No Brasil o que temos é uma QUASE QUE completa negação da auto-estima. (FUVEST, 2003, Redações dissertativas, séc. XXI)

(38) Um país marcado por um processo colonial explorador e cujo domínio político foi reservado QUASE QUE exclusivamente a uma elite econômica preocupada com seus próprios interesses só poderia abrigar uma população com baixo nível educacional, sujeita a manipulações ideológicas que a transformem em uma massa passiva. (FUVEST, 2003, Redações dissertativas, séc. XXI)

Ao optar pelo uso de construções como essas, o indivíduo manifesta seu julgamento sobre o valor de verdade da proposição e também o seu descomprometimento em relação a essa verdade. Essas expressões podem ser classificadas em uma definição proposta por Lima-Hernandes e Casseb-Galvão (2007:195) - “expressões valorativas de subjetividade, do comprometimento, do conhecimento".

Em estudo anterior, empreendido ao longo da pesquisa já mencionada, Nogueira (2010) considerou a trajetória de mudança operada pelo item meio e sustentou a hipótese de que a codificação de atitudes linguísticas se daria via processo de gramaticalização. Ao final da análise, essa hipótese revelou-se ratificada. Em estudos

\footnotetext{
${ }^{8}$ Não nos foi permitido o acesso às redações produzidas nas avaliações do ENEM, o que efetivamente nos levaria ao contato com as produções escritas por candidatos de diversas regiões do país e em situação diversa de avaliação.
} 
posteriormente realizados, com o intuito de se dar continuidade ao trabalho sobre o processo de gramaticalização, percebemos que esse encaminhamento também era respaldado pelos resultados dos estudos de Mendonza \& Baicchi (2007) e de Margerie (2007) com outras construções de valores subjetivos.

A partir dessas constatações, perguntamo-nos se o mesmo estaria ocorrendo com a construção quase que. Também intrigou-nos o fato de, em algumas das melhores redações ${ }^{9}$, estar empregada essa construção inovadora. Isso nos fez refletir sobre a possibilidade de a capacidade de organizar argumentos mais habilidosamente passar justamente pela codificação linguística via construções mais complexas, tais como a de nosso interesse nesta pesquisa. Certamente, isso teria contribuído para que o texto fosse inserido no conjunto das melhores redações.

Lidar com a ideia de codificação linguística das intenções em variados estudos a partir de distintos itens levou os membros do Grupo de Pesquisa CNPq/USP "Mudança Gramatical do Português (Gramaticalização)" à expansão de seus horizontes, adentrando o mundo da cognição. Havia uma forte intuição de que processos cognitivos motivariam mudanças gramaticais empreendidas pelos itens sob análise. Estudar gramaticalização a partir de uma perspectiva puramente linguística mostrou-se absurdo, uma vez que se estaria ignorando o locus em que ela se originaria e se processaria: a mente humana. Estabelecer diálogo com a Psicologia colocou-se, por conseguinte, como objetivo urgente na agenda de estudos do grupo de pesquisa. Desse modo, durante o segundo semestre de 2010, participamos de curso de pós-graduação, na área de Linguística, sobre o tema da cognição; cursamos, no segundo semestre de 2011, disciplina do programa de pós-graduação do Instituto de Psicologia e, ao longo de 2012, contamos com a participação de docentes desse Instituto em seminários organizados por nosso grupo, apresentando-nos conceitos e colocando-nos em contato com teorias e pesquisas que passaram a abrir nosso caminho em direção a uma melhor compreensão a respeito de uma área tão instigante e desconhecida por nós. Dando continuidade a esse processo de aproximação e investigação, cursamos, no primeiro semestre de 2013, duas

\footnotetext{
9 O critério para ser incluída, nesta pesquisa, como parte das "melhores redações" é totalmente derivado das avaliações empreendidas por membros da banca examinadora. Invariavelmente, combinam traços da forma a traços do conteúdo, passando pelo domínio da norma culta depreendido da forma de codificação linguística (ANEXO II). Por isso torna-se mais instigante tomar essas formas inovadoras como objeto de investigação.
} 
disciplinas oferecidas pelo Programa de Pós-graduação da área de Filologia e Língua Portuguesa - Processos de Cognição e de Linguagem I e II: Diálogos Interdisciplinares - as quais contribuíram de modo decisivo para o aprofundamento do conhecimento sobre as relações entre língua e cognição, além de terem possibilitado o contato com questões relevantes de diferentes áreas de estudo, como a Psicologia, a Biologia e a Psiquiatria.

Foram também empreendidas leituras e discussões sobre o tema pelo grupo em encontros realizados ao longo dos últimos anos. Tomasello (1999, 2008), Croft (2009) e Givón (1995) nos guiaram nessa empreitada.

Além do viés da cognição, também nos interessamos, nesta pesquisa, pela incorporação de usos inovadores na escrita formal. Nessa medida, consideramos interessante a realização de uma pesquisa que nos desse uma mostra, ainda que grosso modo, a respeito da situação do ensino da gramática. Como o processo de incorporação de novas construções à língua prevê uma inovação em âmbitos que possam gerar uma mudança no futuro, acreditamos que o espaço escolar seja um locus importante para monitoramento, mas lidar com uma amostragem quantitativamente representativa das aulas e das interações professor-aluno exige maior fôlego e tempo do que aquele disponível para o trabalho de mestrado. A solução para transpor esse problema metodológico está na identificação de um instrumento que, estando presente na sala de aula, deponha sobre a linguagem veiculada e também sobre o conteúdo e a forma de interação mediadora do professor com o aluno e do aluno com o conteúdo a ser estudado. O livro didático pareceu-nos ser o meio que pôde se converter em um objeto de uma observação - ainda bem cautelosa - durante uma das fases de desenvolvimento da pesquisa.

Cremos ser possível afirmar que o tipo de abordagem realizada por esses materiais acerca dos conteúdos linguísticos seja uma pista bastante próxima da forma como esses têm sido trabalhados em sala de aula. Estabelecer, assim, contato com essa área do ensino nos parece importante para compreender o contexto com o qual nos deparamos ao analisar as redações produzidas pelos alunos nas provas vestibulares.

Procedemos, em consequência, à análise de livros didáticos aprovados por comissão do PNLD (Programa Nacional do Livro Didático) e gramáticas cujo amplo uso em salas de aula é referendado por professores e escolas em seus programas de curso. A falta de associação entre o ensino de gramática e o trabalho com produção 
textual, por exemplo, era presente no modelo anterior dominante antes do PCN (Parâmetros Curriculares Nacionais). O mesmo ocorreu com os operadores textuais demandados por intenções discursivo-pragmáticas. Agora, num momento pós-PCN, é pretensão identificar veios sociointeracionistas, cognitivos e funcionalistas no ensino de língua portuguesa, e essa observação se dará exatamente no livro didático, posto que, passando por uma avaliação que considere as prerrogativas dos PCNs como critérios necessários, esperamos poder identificar a mudança da realidade de ensino da língua portuguesa pelo menos nos livros selecionados.

A hipótese inicial era a de que quase codificaria incerteza, mas as análises conduziram para um novo caminho. Como pudemos relatar até aqui, três objetivos altamente imbricados guiam os procedimentos metodológicos adotados nesta pesquisa. São eles: (i) descrição dos padrões construcionais de quase que; (ii) identificação de motivação cognitiva subjacente às mudanças funcionais; e (iii) discussão do ensino dessa gramática fluida e dinâmica num momento pós-PCN, em cujos pressupostos estão orientações sociointeracionistas.

É a partir desses procedimentos que esperamos identificar os padrões construcionais de incerteza, bem como os contextos de uso motivadores para o surgimento desses padrões. 


\section{Introdução}

Tomamos como objetivo a investigação do processo de gramaticalização do item quase e sua nova configuração na construção quase que no português do Brasil. Esse propósito envolve as tarefas ${ }^{10}$ de (i) análise de construções com grau de polaridade negativa em termos de certeza e de convicção do falante e (ii) rastreamento histórico de dados que possam trazer esse uso para, então, (iii) descrevê-los com base em princípios funcionalistas, dentre os quais se inclui o princípio de iconicidade, especialmente em seu subprincípio de quantidade (GIVÓN, 1995). Como resultado ${ }^{11}$ dessa análise, espera-se (iv) identificar o processo de gramaticalização da construção quase que, aparentemente uma forma concorrente de quase, porém, intuitivamente, uma expressão de função inovadora.

Dado o interesse pelo ensino de gramática e pela incorporação de usos inovadores na escrita formal, selecionamos como corpus redações dissertativas de candidatos aos vestibulares da Fuvest (Fundação para o Vestibular da USP). A situação de produção desses textos (concursos vestibulares) somada aos objetivos do escrevente (adesão ao padrão culto e aprovação no vestibular) seria suficiente para que usos inovadores ou vinculados à escrita informal fossem elididos dos textos. Contudo, se considerarmos que, quanto maior a complexidade cognitiva, maior a complexidade da codificação linguística, ou, de outro modo, quanto maior a quantidade de informações, maior a quantidade de forma linguística requerida, então a diferença entre o item aproximativo quase e a construção quase que poderá advir justamente de uma informação mais complexa e mais abstrata que o escrevente pretende codificar. Esta é nossa hipótese: uma nova função orientada pelo princípio de iconicidade deve ter guiado a mudança gramatical do item quase em sua nova configuração quase que. É objetivo deste trabalho identificá-la.

Verificamos, após a análise de 758 redações, que, ao codificar intenções de atenuar um sentido, de demonstrar incerteza sobre o fato ou de se descomprometer da opinião expressa, os candidatos optam pelas seguintes expressões parece, parece que,

\footnotetext{
10 Essas e outras tarefas serão apresentadas e descritas no capítulo II, FUNDAMENTOS METODOLÓGICOS.

11 Os resultados dessa análise, bem como de outras etapas da pesquisa, serão apresentados no capítulo III.
} 
pode ser e pode ser que - expressões que apenas por estarem em $3^{\mathrm{a}}$ pessoa já indiciariam um distanciamento - além de outras expressões de base nominal: possivelmente, provavelmente, talvez, quase e quase que. Com exceção de possivelmente, provavelmente e talvez, todas as demais expressões não constam em livros didáticos e gramáticas normativas, como será demonstrado no capítulo III "Quase e quase que: delimitação do objeto em sua tradição e inovação" - devido, hipotetizamos, ao caráter equivocadamente menos tradicional ${ }^{12}$ dessas expressões, as quais, por não serem incluídas como exemplares nas gramáticas tradicionais, são encarados como não contemplados como corretos nos livros didáticos. Essa hipótese será checada no capítulo III.

Chama-nos a atenção, no entanto, o fato de que essas expressões estão muito presentes nas redações consideradas pela banca examinadora como as melhores de cada ano. Apesar de termos como certo que a utilização dos exemplares ilustrativos dos padrões formais e cultos não estariam necessariamente vinculados à capacidade de produzir textos bem desenvolvidos, encadear argumentos adequadamente e manter a coesão e coerência textuais - habilidades certamente essenciais para se alcançar uma boa pontuação - é evidente que usos não apreciados pela norma ou estigmatizados por professores de português serão motivos de punição, em termos de notas, e não figurariam entre os casos exemplares de boas redações. Isso nos motiva a investigar mais detidamente esses usos também à luz dos usos modelares, fonte de inspiração para a normatização gramatical.

No plano inicial do projeto, intencionava-se trabalhar apenas com redações dissertativas de candidatos ao vestibular. O percurso da pesquisa, entretanto, exigiu um rastreamento histórico que fosse além do cotejo com as acepções registradas em dicionários e que nos possibilitasse a observação, ainda que breve, das funcionalidades assumidas por quase no passado. Como na análise de qualquer fenômeno em mudança, o recuo no tempo é interessante encaminhamento metodológico. Esse distanciamento temporal pode, muitas vezes, explicar muito do que já ocorre sincronicamente, mas que não pode ser percebido com nitidez; além disso, favorece a compreensão da direção assumida pela mudança. Recorremos, assim, a cartas escritas por redatores e leitores no século XIX. Dado que o corpus sincrônico ficou restrito à expressão de futuros

\footnotetext{
${ }^{12}$ Lembremo-nos de que a tradição, nos estudos gramaticais, é demonstrada pelo uso corrente dos itens e expressões em obras literárias.
} 
escreventes cultos, outra amostra sincrônica foi também incorporada à pesquisa. A descrição desses materiais estão, junto à justificativa para tal incorporação, apresentada no capítulo II - "Fundamentos Metodológicos".

Devido ao peso exercido pelos processos intencionais e cognitivos no desenvolvimento dos itens e construções gramaticalizados na língua (GIVÓN, 1995), como foi mencionado na APRESENTAÇÃO, faz-se necessária a realização de uma análise voltada para as motivações cognitivas desses deslizamentos funcionais. Essa grande influência assumida pela cognição e pela intenção no estudo de gramaticalização será abordada no capítulo I, FUNDAMENTAÇÃO TEÓRICA, que apresenta, além de reflexões sobre teorias a respeito da gramaticalização e de princípios funcionalistas, todo o percurso de leituras que realizamos para procurar entender o mundo da cognição e todo o embasamento no qual nos apoiamos para relacioná-lo aos estudos linguísticos que empreendemos. 


\title{
Capítulo I
}

\section{Fundamentação Teórica}

\begin{abstract}
Encontram-se expostas, neste capítulo, as reflexões nascidas da interação entre leituras realizadas sobre o tema associadas às análises pontuais que foram sendo testadas como soluções provisórias ou estudos-pilotos, os quais antecederam a redação desta dissertação. A perspectiva adotada é a cognitivo-funcional, porém num diálogo constante com as postulações teóricas de autores que trataram da língua em momentos diversos do pensamento linguístico. Assim, tanto a semelhança - e o diálogo convergente decorrente - quanto a diferença de tratamento - e o diálogo divergente decorrente favoreceram o alinhamento das ideias neste capítulo expostas.
\end{abstract}

\section{O estruturalismo: a língua como estrutura}

Os estudos linguísticos no século XX são caracterizados pelo predomínio de duas abordagens: a estruturalista e a gerativista. A primeira conceitualiza a língua como uma entidade de dependências internas, ou seja, uma estrutura. Seu fundador, Saussure, tinha como base de sua concepção de língua a distinção entre langue - o sistema de linguagem - e parole - o uso real desse sistema. Langue, para Saussure, é um sistema social, um conjunto de convenções, um código compartilhado por uma comunidade. Parole, por outro lado, é uma atividade psicológica individual que consiste na produção de combinações específicas dos elementos presentes no código. Haveria, entretanto, uma lacuna entre essas definições: qual seria a ponte que liga a distância existente entre o social e o psicológico, o coletivo e o individual, o código e seu uso real?

A noção de estrutura, a qual, como observamos em seu rótulo, é central para a teoria em questão, vincula-se à ideia de que a língua exerce sua função comunicativa graças ao fato de ser formada por elementos que mantêm entre si determinadas relações 
e que são definidos, justamente, com base nessas relações. Assim, em "faca", identificamos um elemento inicial "f" não tanto com base em suas semelhanças, mas, principalmente, com base nas relações que ele mantém, na língua portuguesa, com outros elementos do sistema fônico, dos quais deve ser considerado distinto. Por exemplo, "faca" é diferente de "vaca"; como "bala" é diferente de "mala". Para o estruturalismo, identificamos, com um jogo de oposições, elementos diversos entre os quais ocorrem determinadas relações, no sistema linguístico e na estrutura do discurso.

O estruturalismo passou a ter seus estudos divididos basicamente em dois grandes polos: o formalista - focado na forma linguística - e o funcionalista - dedicado ao estudo da função que a forma linguística desempenha no ato comunicativo. Diferentemente do modo como a língua vinha sendo conceitualizada, o polo funcionalista a percebe como um instrumento de comunicação, não devendo ser, portanto, analisada como uma estrutura fixa, mas, sim, flexível, sujeita a alterações constantes resultantes das diferentes situações comunicativas.

Analisada sob a perspectiva formalista, uma palavra ou uma construção será sempre observada isoladamente, ou seja, fora de seu contexto de uso, o que leva necessariamente, por exemplo, a uma relação arbitrária entre uma sequência sonora e um significado - ou objeto ao qual se refere. Voltando-se para uma perspectiva funcionalista, contudo, o que se tem é a análise da língua em seu contexto de uso, em situações reais de comunicação, observando-se mecanismos que se repetem e que refletem um processo de criação de novas funções para formas já existentes.

A perspectiva formalista propõe o estudo imanente da língua, segundo o qual a língua deve ser estudada em si mesma e por si mesma. Desse modo, ficam excluídas as relações entre língua e sociedade, língua e cultura, língua e distribuição geográfica, ou qualquer outra relação que não seja absolutamente relacionada com a organização interna dos elementos que constituem o sistema linguístico.

\section{O gerativismo: a prevalência do inatismo}

Chomsky, o fundador da gramática gerativa, procurou resolver a questão da necessidade de uma ponte que ligasse o social e o psicológico, o coletivo e o individual, o código e seu uso real, introduzindo os conceitos que foram por ele denominados competência e desempenho. O último é praticamente equivalente ao termo saussureano 
parole, já o conceito de competência refere-se à gramática interna do usuário da língua, ao conhecimento que ele possui do sistema linguístico - o gerativismo concebe a existência de uma estrutura mental inata - e que coloca em desempenho.

O autor introduz nos estudos linguísticos a noção de cognição, acentuando a importância da natureza da mente humana e dos princípios gerais inatos que a caracterizam para a compreensão do fenômeno da linguagem. Chomsky ressalta o componente criativo da língua humana, pontuando o papel primordial desempenhado por determinados processos mentais que, segundo ele, são inerentes à espécie humana. O objetivo da linguística passa a ser o de explicar o funcionamento de um órgão mental particular responsável pelo funcionamento da linguagem humana. O papel do estímulo externo fica restrito à função de ativar o funcionamento desse órgão.

O gerativismo demonstrou que os humanos não decoram por estímulo externo as frases que utilizam e ressaltou a criatividade humana para a linguagem. Dessa forma, a linguística deu um importante passo na direção de uma teoria capaz não apenas de descrever um conjunto de dados observados, mas também de prever dados novos; em outras palavras, uma teoria não apenas descritiva, mas explicativa. Entretanto, uma nova lacuna é introduzida, uma vez que, em seu recorte, o gerativismo preocupa-se em enfatizar a natureza genética da língua, não abordando seus aspectos sociais e o uso concreto da língua nas situações reais de comunicação, ou seja, os aspectos de ordem sociointerativa associados à linguagem. Assim, mantém-se a noção de linguagem como um sistema autônomo, indiferente aos interesses do sujeito que o utiliza. Não leva em conta, dessa forma, a perspectiva de quem produz o discurso ${ }^{13}$ ou sua criatividade ao adaptar sua fala aos diferentes contextos comunicativos, logo, não pretendendo dar conta de aspectos básicos como a variação e a mudança.

Os significados também acabam por ser negligenciados pela gramática gerativa. Através da interação social e da consequente troca de ideias, mudam-se as concepções de mundo, o que é refletido principalmente no significado de expressões linguísticas. No entanto, a evolução da língua não pode ser entendida fora do contexto social, como bem enfatizou Beckner et alii (2009:3):

\footnotetext{
${ }^{13}$ Entende-se discurso, aqui, como a construção e a troca intersubjetiva de sentidos em uma determinada situação intercomunicativa. Refere-se a qualquer instância de uso da linguagem em todas as suas manifestações, qualquer produção e compreensão de enunciados em um contexto de interação verbal.
} 
Primate species are particularly socially interactive mammals, but humans appear to have emphasized this type of social interaction to an even greater extent. This means that language evolved in the context of an already highly interactive social existence. Language plays a fundamental role in human society and culture, providing the central means by which cultural knowledge is transmitted, elaborated, and reformed over time. ${ }^{14}$

\section{A perspectiva cognitivo-funcional}

O funcionalismo destaca o discurso individual, considerando-o como nível gerador do sistema linguístico, que, por sua vez, está em constante transformação, sempre sendo negociado pelos usuários da língua quando em situações comunicativas. Para o funcionalismo, a dicotomia estabelecida entre langue e parole não é possível. Não há como separar os conceitos. Aquilo que é acidental no discurso - o que seria parole - passa a ser a gênese do sistema - o conjunto de convenções, langue - que, por sua vez, alimenta o próprio discurso.

Tendo em vista que a Gramática Funcional objetiva a descrição e a explanação de línguas estabelecendo como foco os aspectos pragmático e psicológico, analisar o entorno comunicativo - em que a motivação e objetivos para a interação verbal são questões centrais - é imprescindível, assim como estabelecer correlações com os processos mentais envolvidos na interpretação e produção das expressões.

A corrente cognitivo-funcional abandona dicotomias tradicionais como racionalismo/empirismo ou inato/aprendido, uma vez que afirma ser problemático distinguir com exatidão o que é inato do que é aprendido e, mais do que isso, ser errôneo fazer tal distinção, já que inato e aprendido devem ser pensados como complementares.

É importante ressaltar que a principal crítica que os cognitivistas fazem à tradição gerativista não se refere à hipótese do inatismo. Os humanos parecem, de fato, possuir estruturas e habilidades inatas que os capacita a aprender e usar uma ou mais línguas. A crítica recai principalmente sobre a postulação de que essas estruturas são

${ }^{14}$ Espécies primatas são mamíferos particularmente interativos socialmente, mas humanos parecem ter conduzido esse tipo de interação social para uma extensão ainda maior. Isso significa que língua evoluiu no contexto de uma existência social já altamente interativa. Língua desempenha um papel fundamental na sociedade e cultura humanas, promovendo os significados centrais, através dos quais o conhecimento cultural é transmitido, elaborado e reformado ao longo do tempo. (tradução sugerida) 
específicas da linguagem. Os cognitivistas não consideram a linguagem como um componente autônomo da mente, ou seja, independente de outras faculdades mentais. Na perspectiva cognitivo-funcional, o uso da linguagem implica restrições provenientes de capacidades humanas, como atenção, percepção, armazenamento de informações na memória, simbolização, as quais estão altamente conectadas ao sistema comunicativo e ao aparato cognitivo. É, em suma, proposta uma não distinção entre conhecimento linguístico e não linguístico.

A tendência do funcionalismo é a de focalizar os mecanismos que geram a mudança linguística como sendo motivados por fatores comunicativos e cognitivos, tais como automatização, habituação, descontextualização e categorização. São processos que se dão no emprego de construções linguísticas na interação comunicativa ao longo do tempo e estão, então, relacionados ao modo como falantes/escreventes "embalam" suas conceitualizações objetivando-se atingir o sucesso na comunicação interpessoal. Nesse sentido, Martelotta \& Areas afirmam que seriam o foco do funcionalismo:

(...) as forças cognitivas que atuam no indivíduo no momento concreto da comunicação e que se manifestam de modo universal, já que refletem os poderes e as limitações da mente humana para armazenar e transmitir informações. (MARTELOTTA; AREAS, 2003:28)

Enquanto Chomsky defende a ideia da gramática universal inata a todos os seres humanos, teóricos do funcionalismo demonstram haver, sim, universais, contudo, não referentes a um sistema linguístico. Universal seria, na realidade, a forma como forças cognitivas se processam na mente de cada ser humano no momento da interação com outro.

Paul (1966:27), muito tempo atrás, já afirmara que “Os processos psicológicos mais simples são iguais em todos os indivíduos, as suas particularidades baseiam-se só em combinações diversas desses processos simples" e que, ainda, é justamente essa regularidade de processos linguísticos nos indivíduos mais diferentes a base mais importante para um conhecimento científico dos mesmos. Esse conceito de universalidade dos processos cognitivos entre os humanos é defendido por etólogos, cujos principais representantes, Lorenz e Tinbergen (1952), provaram que os animais atuam de acordo com programas inatos e que a aprendizagem, como também irá defender, trinta anos depois, Eibl-Eibesfeldt (1976), completa essas estruturas de 
comportamento herdadas. A complementariedade entre o natural e o cultural é, portanto, defendida pela etologia e pelo funcionalismo, guardadas as devidas espeficidades. A comparação entre línguas não aparentadas foi um marco nos estudos funcionalistas, pois o fato de podermos recolher informações sobre os deslizamentos funcionais e sobre o processo de gramaticalização de intenções em quaisquer línguas nos revela que a língua é, realmente, uma forma de cognição. Contudo, as diferenças entre as gramáticas das línguas apontam para a existência do fator sociocultural, o qual impede que a língua possa ser tida como unicamente cognição e que seja, antes, vista como resultado da atuação, em conjunto, do natural (cognição) e do cultural.

O universalismo concebido pela proposta cognitivo-funcional é diferente do universalismo gerativista, na medida em que a procedência deste está na biologia, enquanto a daquele está em uma relação equilibrada entre biologia e cultura.

Sendo motivados por essas forças cognitivas, levanta-se a reflexão a respeito dos caminhos do processo de gramaticalização: seriam também universais? Bybee (2003a:150) é categórica ao afirmar que "The examination of the grammaticalization process across many grammatical domains and many different languages makes it clear that the true language universals are universals of change" ${ }^{\prime 15}$. Ao se referir aos caminhos do processo de gramaticalização, a autora deixa clara mais uma vez sua teoria sobre os universais ${ }^{16}$ : "Such paths (grammaticalization paths) are universal in the sense that development along them occurs independently in unrelated languages. ${ }^{17}$ ", (BYBEE, 2003a:149). A partir dessa premissa, Beckner et alii (2009:8) postulam que é razoável assumir que a fonte original da gramática na linguagem humana conformou-se no seguinte processo:"As soon as humans were able to string two words together, the potential for the development of gramar exists, with no further mechanisms other than the sequential processing, categorization, conventionalization, and inferencemaking. ${ }^{18,}$

${ }^{15} \mathrm{O}$ exame do processo de gramaticalização entre vários domínios gramaticais e várias línguas diferentes deixa claro que os reais universais da língua são universais de mudança. (tradução sugerida)

${ }^{16}$ Para exemplificar, temos os verbos indicadores de deslocamento de um corpo para frente, os quais passaram a indicar futuro em francês, inglês, português, espanhol, entre outras. Para maiores detalhes, consultar Heine \& Kuteva (2002), obra que aborda possíveis universais de mudanças investigados em diversas línguas.

17 Caminhos como esses (caminhos de gramaticalização) são universais no sentido de que o desenvolvimento ao longo deles ocorre independentemente em língua não aparentadas. (tradução sugerida)

18 Assim que os humanos foram capazes de articular duas palavras juntas, o potential para o desenvolvimento da gramática passou a existir, com mecanismos não outros que os de processamento 
A gramaticalização, processo de mudança linguística, assume lugar de destaque no âmbito dos estudos funcionalistas de forma uníssona no início do século XX e, de forma mais abrangente e impactante, no final do século XX. Trazendo como foco das análises o aspecto não estático da língua, os estudiosos da gramaticalização têm demonstrado que as línguas estão constantemente sofrendo alterações e, consequentemente, que novas construções estão a todo momento emergindo. A constatação disso fez com que Hopper (1991) surgisse no cenário ratificando a ideia de língua como processo contínuo. Não há uma gramática ${ }^{19}$ pronta. O que temos é uma gramática em constante processo de evolução. Do ponto de vista sincrônico, ou seja, pensando em um recorte temporal no qual determinados aspectos parecem manter-se constantes ao longo de uma parte da trajetória de uma língua, a gramática pode ser definida como um "conjunto de regularidades decorrentes de pressões cognitivas e, sobretudo, de pressões de uso" (FURTADO DA CUNHA; COSTA; CEZARIO, 2003:50). Assim, quando um fenômeno linguístico muito frequente na língua passa a ser empregado de forma previsível, forma-se uma regularidade, que se torna, então, um dos constituintes da gramática.

Assumir esta atitude frente à língua significa rejeitar uma modelização que ignora zonas de imprecisão ou de oscilação, as quais são as verdadeiras testemunhas do equilíbrio instável que caracteriza a própria vida da língua. Equilíbrio este que, para Givón (2005), estaria entre a ordem e o caos. O chamado paradoxo do Yin e Yang, postulado pelo autor, sustenta a ideia de que fatos diversos e amparentemente contraditórios são, na verdade, um todo complexo e em equilíbrio. Propriedades diversas podem conciliar-se em favor de uma adequação ao objetivo, ao contexto. Saber o que é correto é uma questão insignificante fora de um contexto dinâmico. O que o define como erro é a consciência humana. O indivíduo, desconhecedor desse dinamismo, passa a rejeitar uma construção aparentemente nova, pois há uma pressão normativa para que ela não seja usada. Bechara (1999:507), ao tratar das construções constituídas por que, assim afirma:

\footnotetext{
sequencial, categorização, convencionalização, e inferenciação. (tradução sugerida)

${ }^{19} \mathrm{O}$ conceito de gramática admitido pela linguística congnitivo social foi bem explanado por Furtado da Cunha et alii (2013): "conjunto de esquemas/processos simbólicos utilizado na produção e organização de discurso. (...) configura-se em categorias morfossintáticas rotinizadas, exibindo padrões funcionais mais regulares e formas alternativas em processo de mudança motivada por fatores cognitivo-interacionais".
} 
Muitas vezes emprega-se que depois de advérbio onde a rigor poderia ser dispensado. São comuns as linguagens: talvez que, apenas que, felizmente que, oxalá que, quase que, enquanto que, embora que. Puristas têm condenado tais modos de dizer. (grifo nosso)

O uso, contudo, é regrado e uniforme. É reflexo do processamento cognitivo. Os linguistas, que estão atentos a essa replicação de hábitos, reconhecem uma coerência de desenvolvimento e não admitem que seja considerado erro o emprego de uma nova construção, dado seu conhecimento profundo do movimento linguístico. É este o paradoxo, o qual sustenta o equilíbrio: a língua mantém sua identidade histórica, a despeito de profundas mudanças superficiais se evidenciarem. Algo que é errado, na consciência, pode ser totalmente possível e correto nos usos inconscientes ou habituais, na medida em que as inovações - sendo as gramaticais sempre mais invisíveis do que as inovações lexicais - vão se encaixando no sistema, reestabelecendo o equilíbrio.

\subsection{Funcionalismo e o ensino da língua}

Na LDB (Lei de Diretrizes e Bases da Educação Nacional), de 1971 (LEI No 5.692), o que se verificava era uma ênfase na fixação da nomenclatura gramatical, frequentemente dissociada da análise de conteúdos gramaticais em uso a partir de sua ocorrência no discurso. Privilegiava-se a repetição de conteúdos e não o exercício reflexivo efetivo. Com a LDB de 1996 (LEI No 9.394), sobretudo a partir das prerrogativas presentes nos PCN (Parâmetros Curriculares Nacionais), tem-se o início de uma mudança de rumo da proposta de ensino de língua portuguesa. Passa a ser privilegiada a utilização competente da língua não só como instrumento de acesso e apropriação de bens culturais e participação ativa no mundo letrado, como também, e de forma acentuada, sua utilização na resolução e superação de situações e problemas no cotidiano.

\footnotetext{
Toda educação verdadeiramente comprometida com o exercício da cidadania precisa criar condições para o desenvolvimento da capacidade de uso eficaz da linguagem que satisfaça necessidades pessoais - que podem estar relacionadas às ações efetivas do cotidiano, à transmissão e busca de informação, ao exercício da reflexão. (BRASIL, MINISTÉRIO DA EDUCAÇÃO, 1998).
} 
Sendo assim, trata-se de uma proposta de ensino fundamentada no funcionalismo, a partir da qual o aluno trabalha questões linguísticas para propósitos pragmáticos e comunicativos. O objetivo é aprimorar a capacidade de compreensão e expressão em contextos de comunicação oral e escrita. Entretanto, de um modo geral, o ensino de português nas escolas ainda se encontra condicionado pela orientação normativo-prescritiva, aprofundando o abismo entre a língua escrita formal e a língua oral que utilizamos nas interações comunicativas de nosso cotidiano. Essa situação contribui para desestimular o interesse dos alunos pelo aprendizado da língua portuguesa, vista como difícil, complexa e dotada de um imenso número de regras às quais esses indivíduos não conseguem atribuir sentido. A língua, que é, por natureza, dinâmica, criativa e produtiva, é ensinada como estática. $\mathrm{O}$ aprendizado de um conjunto de regras de uso da escrita padrão não deveria ser, isoladamente, o objetivo final do processo de ensino. Uma nova abordagem à língua em sala de aula é necessária.

Aplicando o funcionalismo ao ensino de língua, as questões relativas à morfologia e à sintaxe deixam de representar um fim em si mesmas para se constituírem em conteúdos cuja análise deva contribuir para a construção do desempenho linguístico competente e eficiente. Propõe-se, ainda, que somente em situação de uso, em funcionamento, é possível a análise linguística de modo a que a linguagem seja compreendida como um sistema dinâmico que se adapta às necessidades de comunicação dos seus usuários . Afirmar que a língua em uso é o reflexo da experiência humana, permeada de crenças, intenções, emoções e necessidades, e que é maleável e emergente, é referir-se ao conceito básico do funcionalismo. De fato, Langacker (1987) assim definiu a língua: "a massive colection of heterogeneous constructions, each with affinities to different contexts and in constant adaptation to usage" ${ }^{20}$, ou seja, emergerindo constantemente. Essa definição conforma-se à que Bybee \& Hopper (2001:13) propuseram para gramaticalização: "the mechanism by which structure emerges from language use 21 ",

Preocupados em lidar com as diferentes funções assumidas pelas construções linguísticas, os funcionalistas desenvolvem estudos de grande valia para o ensino de

\footnotetext{
${ }^{20}$ Uma maciça coleção de construções heterogêneas, cada uma com afinidades a diferentes contextos e em constante adaptação ao uso. (tradução sugerida)

${ }^{21} \mathrm{O}$ mecanismo a partir do qual a estrutura emerge do uso linguístico. (tradução sugerida) Apesar de concordarmos com Bybee \& Hopper nesse conceito, preferimos o termo "construção" ao termo "estrutura".
} 
língua, uma vez que concentram a atenção dos alunos no funcionamento dos elementos a serem aprendidos e não na descrição exaustiva de suas propriedades. Estas seriam deduzidas do funcionamento e não apenas memorizadas pelos alunos, levando-os, assim, ao aprendizado efetivo. O ensino de conteúdos gramaticais, num plano voltado para a competência linguística, deveria, desse modo, ser contextualizado, baseado no reconhecimento das diferentes funções assumidas pelas construções linguísticas em diversos contextos de uso. Tratar de tais conteúdos de modo descontextualizado, puramente atribuindo rótulos e propriedades aos itens gramaticais, dificilmente resultará em um aprendizado efetivo, pois estes não irão adquirir sentido para os alunos, que recorrerão à pura memorização de regras gramaticais.

Dessa forma, ao ensinar o conceito de advérbio, por exemplo, seria interessante, ao invés de simplesmente afirmar que este "modifica um verbo, um adjetivo ou outro advérbio", apresentá-lo aos alunos em diferentes contextos, levando-os a refletir a respeito das funções por ele assumidas em cada situação. Ao analisar uma sentença como "A garota trabalhou muito.", os alunos não precisam da aprendizagem explícita para reconhecer que a palavra "muito" está modificando a palavra "trabalhou" e não a palavra "garota". Seria um conhecimento implícito. Ao passo que saber que a palavra "trabalhou" é classificada como um verbo e que, por conseguinte, "muito" será classificada como um advérbio, exige uma aprendizagem explícita. Por conseguinte, reconhecer o funcionamento de uma construção, fazendo uso da aprendizagem implícita, deveria sempre preceder a aprendizagem explícita, que consistiria em, por exemplo, denominar categorias gramaticais. Essas deveriam ser trabalhadas em uma perspectiva funcional, com base na noção de prototipicidade, que distribui os diversos membros das categorias limítrofes em um continuum. Em outras palavras, a divisão das palavras em classes gramaticais deveria ser um exercício de reflexão sobre gradação e prototipicidade e não uma distribuição em categorias estanques. A relação existente entre as diversas classes condiz com os usos, que são dinâmicos, assim como com a estratificação social, que é gradual. O modo mais eficiente para se demonstrar um sistema dinâmico e gradual em movimentos de variação e mudança é aquele baseado em termos de propriedades. Assim, por exemplo, duas palavras de classes distintas podem, provavelmente por estarem em processo de mudança, aproximarem-se em propriedades. A construção quase, como verificaremos, é classificada como advérbio pelas gramáticas, no entanto, nem sempre assume essa função nos dados de uso real da 
língua. Analisar a língua em uso, levantar hipóteses e partilhar ideias é o caminho a ser seguido para que os alunos tornem-se capazes de compreender o funcionamento da gramática. É o caminho adotado nesta dissertação.

A visão que se tem a respeito do conceito de gramática também precisa ser revista. Além das palavras ou construções tradicionalmente consideradas como pertinentes ao âmbito gramatical, construções como expressões idiomáticas, construções reformuladoras (quer dizer, digamos que, etc.), de apoio discursivo (entende?, sabe?, né?), dentre outras, também devem ser pensadas como gramaticais. São elementos de alta frequência e que, por isso, devem ser integrados como parte da gramática da língua. Nesse sentido, observamos uma forte vinculação entre discurso e gramática. A morfologia e a $\operatorname{sintaxe}^{22}$ são resultado das estratégias de organização da informação empregada pelos falantes no momento da interação discursiva. A gramática constitui-se, dessa forma, como o resultado da regularização ou rotinização de estratégias discursivas recorrentes, ou seja, tem sua origem no discurso ${ }^{23}$. E é dessa forma que ela deve ser estudada, percorrendo-se o caminho desde o discurso e a partir das funções por ela desempenhadas na comunicação.

Expor o aluno às mais diversas situações comunicativas contribuirá para o desenvolvimento de sua capacidade de adequar-se a essa variedade. As situações de interação linguística não acontecem independentemente do que está na mente de cada um dos interlocutores, assim como o que está na mente é influenciado pelo que acontece na interação. Essa interação bidirecional é ambiente proliferador de padrões gramaticais emergentes que se vão, com o uso, fixando. Daí a importância da observação sistemática do uso da língua em situações cotidianas de comunicação.

Assim como o funcionalismo, também seria de grande importância relacionar o ensino da língua ao conceito de gramaticalização. A associação entre esses campos foi proposta por Lima-Hernandes e Casseb-Galvão (2007):

Diferentemente do que fez a escola do século XX com o ensino de língua portuguesa em qualquer série, em que muito se lê, muito se exercita e pouco se identifica na atuação do indivíduo nessa mesma gramática (o ensino estático), com os desenvolvimentos mais recentes da ciência, especialmente em

\footnotetext{
${ }^{22}$ Numa perspectiva funcional, os componentes semântico e sintático não são autônomos em relação ao componente pragmático.

23 Entendemos "discurso" como um conjunto de estratégias criativas empregadas pelo falante para organizar funcionalmente seu texto, falado ou escrito, em uma determinada situação comunicativa.
} 
gramaticalização, torna-se necessária uma revisão de postura por parte de todos aqueles que lidam com língua e ensino. É importante que a consciência sobre os movimentos linguísticos - que não são caóticos, desordenados nem tampouco inapreensíveis - seja ampliada para que sejam respondidas perguntas simples, como: "De onde vêm as conjunções do português?", "como fazer o aluno compreender as motivações de um predicado verbo-nominal?", "por que a gramática não trata de objetos direto e indireto ocultos?" (LIMAHERNANDES; CASSEB-GALVÃO, 2007: 158)

As autoras propõem, assim, que as mudanças linguísticas sejam trabalhadas em sala de aula, objetivando à reflexão dos alunos a respeito da gramática e, consequentemente, a um ensino mais consciente. Certas formas inovadoras estão muito presentes nas produções textuais e por isso não devem ser colocadas à margem do momento didáticopedagógico. Lidar com o tipo de emprego inovador é o caminho ideal para aumentar o grau de consciência linguística dos falantes e escreventes do português. Segundo as mesmas autoras, "esse conhecimento poderá desenvolver no aluno habilidades para reconhecer a funcionalidade de diversos elementos e para usá-los nos mais diversos gêneros textuais" (id. ib.).

O trabalho com a gramaticalização em sala de aula coloca-se como elemento essencial, uma vez que os estudos desse processo revelam que a língua é funcional e também dinâmica. Além disso, trabalhar com esse processo pode tornar possível aos alunos compreender como as intenções são codificadas sintaticamente. Os aprendizes precisam desenvolver a percepção de que a língua não é uma estrutura estática e que deve ser concebida como uma atividade social, que não existe por si mesma, mas, sim, devido ao uso para fim de interação entre os seres humanos e para a comunicação de intenções. O aprendizado da língua para fins comunicativos deve ser, assim, priorizado. Daí ser também necessário propor a revisão da desassociação, em sala de aula, entre o ensino da gramática e o trabalho com a produção de texto. Ao ensinar a gramática de forma descontextualizada, desvinculada de uma situação comunicativa, ela se torna ainda mais complexa para os alunos, não levando a um aprendizado efetivo, como argumentado anteriormente.

Antes dessas autoras, Travaglia (2003) já chamara a atenção para a necessidade de se questionar a dicotomia estabelecida quando se dizem "aspectos gramaticais e textuais da fala/escrita”. Segundo o autor, dizer assim faz pensar que o que é textual não 
é gramatical e o que é gramatical não é textual, posição com a qual não seria plausível concordar. Travaglia explica que:

(...) uma sequência linguística só se transforma em texto quando produz um efeito de sentido entre seu produtor e seu receptor, ou seja, quando faz/tem sentido para alguém. (...) o sentido que uma sequência linguística faz (e que transforma em texto) depende de uma série de recursos, mecanismos, fatores e princípios internos e externos à língua. Todos esses elementos estão de alguma forma inscritos e regularizados na língua, constituindo a sua gramática. Por isto é que se pode afirmar que a gramática de uma língua é o conjunto de condições linguísticas para a significação. (TRAVAGLIA, 2003: 44)

O autor continua o desenvolvimento desses argumetntos afirmando que todos os recursos da língua - sejam eles provenientes dos planos fonológico, morfológico, sintático, semântico, pragmático e dos níveis lexical, frasal, textual-discursivo funcionam como pistas e instruções de sentidos que são postos em conjunto nesta função por mecanismos, fatores e princípios. É dessa ação em conjunto que surgem os efeitos de sentido possíveis para uma determinada sequência linguística usada como texto em uma determinada situação de comunicação.

Dessa forma, quando se estudam aspectos gramaticais de uma língua, estão sendo também estudados os recursos de que essa língua dispõe para que o falante/escritor constitua seus textos de modo a produzir os efeitos de sentido que pretende que sejam percebidos pelo ouvinte/leitor. Do mesmo modo, quando se estudam aspectos textuais da língua, também são estudadas as maneiras como esses recursos funcionam na interação comunicativa, seja através da modalidade escrita, seja através da modalidade falada.

É possível, então, concluir que o texto é apenas um resultado da aplicação da gramática da língua em seus múltiplos planos e níveis. O texto é a gramática da língua em funcionamento. Logo, não há sentido em promover a separação, em sala de aula e nos livros didáticos, entre o ensino de gramática e o trabalho com a produção textual.

O funcionalismo, retomamos, caracteriza-se pela tendência de focalizar os mecanismos que geram a mudança linguística como sendo motivados por fatores comunicativos e cognitivos. 


\section{O conceito de gramaticalização: a necessária renovação linguística}

Um autor que tem investido na relação entre ontogênese e filogênese, porém de uma perspectiva da linguagem, tem sido Tomasello (2003:58). Ele postulou que

\footnotetext{
(...) os símbolos e as construções linguísticas evoluem, mudam e acumulam modificações ao longo do tempo histórico à medida que os homens os utilizam entre si, ou seja, através dos processos de sociogênese. A dimensão mais importante do processo histórico no presente contexto é a gramaticalização.
}

Gramaticalização deve ser compreendida aqui, consequentemente, como um processo importante de renovação linguística. Essa renovação pode ser derivada, no caso das redações e dos resumos de dissertações e teses sob análise, da intenção de revelar um bom domínio da norma culta e, ao mesmo tempo, alta criatividade por parte dos escreventes, o que poderá contribuir para a atribuição de uma nota mais alta pela banca examinadora, no caso dos vestibulandos, e para uma boa impressão aos leitores, no caso dos resumos.

Subjazem a esta dissertação as concepções de língua como atividade no tempo real e de gramática como dotada de um estatuto que é constantemente negociado nas situações comunicativas. Fundamentamo-nos na postulação de que, a rigor, não há gramática como produto acabado, mas sim uma constante gramaticalização.

O contínuo desenvolvimento de novas construções gramaticais é motivado, entre outros motivos, por necessidades comunicativas não satisfeitas, que passariam a requerer novas formas de expressão; pela ausência de designações linguísticas para determinados conteúdos cognitivos. Essa dinâmica promove um contínua (re)organização da mente através da qual um uso novo é incorporado por caminhos produtivos disponíveis na bagagem de conhecimento prévio de todo falante/escritor no exercício de considerar e compreender a perspectiva do outro. Um desses processos é o de gramaticalização.

O processo de gramaticalização é traduzido como uma transformação gradual de um elemento lexical em elemento gramatical ou de um item ou construção gramatical a mais gramatical ainda. Seriam deslizamentos que funcionam como uma válvula de escoamento de itens lexicais para uma nova categoria, mais gramatical. E, mais do que isso, seria a transformação de uma estratégia discursiva em uma construção sintática. É 
por esse motivo que observaremos, em nossa análise a respeito do funcionamento da construção quase (que), que a intenção de codificar informações mais complexas irá refletir-se na sintaxe através do emprego de construções também mais complexas e que a intenção de sinalizar o distanciamento entre expressões será codificada através de distanciamento sintático. Construções mais arraigadas à língua mobilizam-se para o entendimento, explanação e descrição de outras construções menos usuais, que acabam reanalisadas e agregadas às primeiras. A sintaxe seria o instrumento por meio do qual se desenvolvem as várias novas funções, especialmente porque, na interação, o material linguístico converte-se numa codificação sintática típica, com uma organização de itens que represente informações e intentos. O léxico, assim, constitui o início do processo de mudança, deslizando de modo muitas vezes imperceptível de um domínio mais concreto para um mais abstrato.

Reflete-se nesse processo o princípio da exploração de velhos meios para novas funções, postulado por Werner e Kaplan (1963), segundo o qual conceitos concretos são empregados para descrever fenômenos menos concretos e mais difíceis de serem conceptualizados. Assim, entidades concretas, perceptíveis pelos nossos sentidos corporais e, por isso, mais claramente delineadas, servem de base para nossa compreensão de ideias abstratas, sensações, de um modo geral, experiências não físicas, que por natureza mental ou sensorial são de mais difícil conceptualização. Esse processo foi por nós observado, como evidenciaremos posteriormente, quando a construção quase passou a assumir novas funções: a partir de sua função vinculada à codificação de quantificação, mais concreta, a construção passou a ter sua atuação também vinculada à qualificação, mais abstrata, relacionada à avaliação, mas não física, e sim epistêmica.

A partir dessa perspectiva, a gramaticalização representa um processo dinâmico que seguiria uma única direção de mudança, sendo, por isso, regida pelo princípio da unidirecionalidade ${ }^{24}$, de acordo com o qual as mudanças ocorreriam sempre na mesma direção, ainda que não linearmente: de categorias mais próximas às experiências mais concretas do indivíduo para as categorias mais distantes do indivíduo, menos concretas. Esse princípio, entretanto, tem sido alvo de questionamentos por parte de autores dedicados ao estudo de mudanças linguísticas num viés cognitivo, mas as razões são

\footnotetext{
${ }^{24}$ Assim como a mente do indivíduo, a menos que sofra de processos patológicos, não involui, o processo de gramaticalização e construcionalização também.
} 
claras: quando se lidam com movimentos não apreensíveis em formas, mas em processos, como é o caso de movimentos sinápticos, torna-se fugidia qualquer tentativa de organização linear.

Os estudos diacrônicos, ao mesmo tempo em que apresentam evidências da unidirecionalidade da mudança, nos provam que diversos usos atuais de determinados elementos linguísticos são encontrados em estágios anteriores da língua, ou seja, não seguiram uma única direção ao longo de seu processo de mudança. A constatação de uma regularidade nos usos de alguns elementos linguísticos em diferentes sincronias ${ }^{25}$ nos impõe a tarefa de repensar o princípio de unidirecionalidade. É importante ressaltar, no entanto, que a unidirecionalidade não nega a irreversibilidade do processo, mas, se esta ocorrer, não mais se configurará como gramaticalização. Muito provavelmente seja um caso de lexicalização, por isso torna-se mais prudente relacionarmos esse princípio aos rumos dos processos cognitivos responsáveis pela produção e transferência de informação entre os diferentes domínios conceptuais - transferência esta que opera a partir de domínios mais concretos em direção a domínios mais abstratos, como observaremos - que os falantes praticam ao utilizarem a língua. Por fim, o fato de elementos linguísticos não seguirem uma única direção ao longo de seu processo de mudança não nega a unidireção. O que temos talvez seja uma forma cíclica; e mesmo a ciclicidade tem uma direção para se desenhar.

Para Martelotta (2003), a mudança de um elemento linguístico é o reflexo de, pelo menos, três aspectos diferentes: tempo e, sobretudo, cognição e uso.

Se tempo é fator necessário para que os processos de mudança se façam sentir, cognição e uso são de fundamental importância para uma teoria que interpreta as línguas humanas como o reflexo do comportamento, no ato concreto da comunicação, das restrições cognitivas associadas à captação de dados da experiência, à sua compreensão e ao seu armazenamento na memória, assim como à capacidade de organização, acesso, utilização e transmissão adequada desses dados. (MARTELOTTA, 2003:69-70)

Desse modo, o autor demonstra que a mudança linguística ocorre pela atuação de fatores cognitivos sob pressão do contexto de comunicação verbal entre usuários da língua. Refutando a perspectiva tradicional de que a mudança está relacionada

\footnotetext{
${ }^{25}$ Enquanto o estudo sincrônico da língua tem como finalidade a descrição de um determinado estado dessa língua em um determinado momento no tempo, o estudo diacrônico (através do tempo) busca estabelecer uma comparação entre dois momentos da evolução histórica de uma determinada língua.
} 
primordialmente à sucessão temporal, o autor nos mostra que há evidências de que o mesmo tipo de transformação linguística pode processar-se repetidamente ao longo do tempo, podendo ser detectada em sincronias bastante distantes entre si. Haveria uma estabilidade dos mecanismos inferenciais que propiciam as extensões de sentido. Ferreira (2003), a título de ilustração, ao apresentar estudo sobre o emprego do verbo poder em diferentes épocas, conclui que basicamente as mesmas estratégias comunicativas e as mesmas inferências relacionadas ao uso desse verbo vêm sendo usadas pelos falantes em diferentes línguas. A autora, ao analisar os dados coletados, mostra que o fato de relacionarmos, por exemplo, a noção de capacidade à de possibilidade e esta à de permissão não tem caráter temporal ou linear, mas sim, tem a ver com leis gerais, de caráter pancrônico ${ }^{26}$, atemporais. Tem a ver com processos cognitivos realizados pelo cérebro humano, que podem, muitas vezes, serem os mesmos em diferentes épocas, diferentes sincronias.

Nesse sentido, todos os itens inovadores são, em outros contextos de usos, itens já em uso na língua. Meillet (1912:131), por exemplo, trata do processo de gramaticalização em termos de mudança categorial, abordando a recategorização (le passage d'un mot autonome au rôle d'élément grammtical ${ }^{27}$ ). Em consonância com essa ideia, Votre (2000) defende que nada na língua desaparece ou é inteiramente novo. Tudo está em processo de adaptação às novas situações comunicativas, sendo constantemente reformatado. O fato é que, devido ao caráter imaginativo de nosso pensamento e às pressões cognitivas e comunicativas às quais somos submetidos a cada interação social, estamos continuamente renovando nossa capacidade imagética e aplicando-a a situações que percebemos como sendo análogas a outras já vivenciadas por nós. A recategorização e outros conceitos relacionados à renovação linguística são, desse modo, guiados pela analogia, processo intrínseco ao pensamento humano.

Um autor que trata mais profundamente do tema da analogia, porém voltado para a perspectiva psicológica do indivíduo é Del Nero (1997). Segundo ele, o ser humano é basicamente um ser analógico ${ }^{28}$. Anttila (2003) explica que o diálogo entre bilhões de células cerebrais - os neurônios - se dá através de inúmeras faixas de contato

\footnotetext{
26 Daí a importância de se aplicar uma perspectiva pancrônica ao estudo de fatos linguísticos, obtendo uma comparação entre várias sincronias da língua.

${ }_{27}$ A passagem de uma palavra independente para o papel de um elemento gramatical. (tradução sugerida)

28 Para Fodor (1985:4), a característica mais intrigante da cognição é "seu não encapsulamento, sua criatividade, seu holismo e sua paixão pelo analógico". Ideia similar pode ser lida em Anttila (2003: 438): "Humans are simply analogical animals".
} 
e não apenas de duas como ocorre nas máquinas digitais. Esse processamento analógico do cérebro humano possibilita, ao lado da capacidade de comunicação, que se façam coisas ainda não realizáveis pelos computadores, tais como entender metáforas ${ }^{29}$ essenciais para o processamento da gramaticalização.

Segundo os estudiosos, a metáfora ocorre através do processo de analogia. A transferência de um domínio conceptual para outro manifesta-se por intermédio de um raciocínio analógico estabelecido entre os domínios. Já a metonímia é promovida através do mecanismo de reanálise. $O$ processo que resulta na metonímia é o de aproximação de significações, gerado, por sua vez, pela proximidade de formas linguísticas sintaticamente. Em muitos dos fenômenos de mudança, via gramaticalização, ambos os processos atuam de forma combinada.

Martelotta et alii (1996: 54) apresentam definições dos processos de metáfora e de metonímia que deixam claras suas relações com a gramaticalização:

(...) a metáfora constitui um processo unidirecional de abstratização crescente, pelo qual conceitos que estão próximos da experiência humana são utilizados para expressar aquilo que é mais abstrato e, consequentemente, mais difícil de ser definido. A metonímia diz respeito aos processos de mudança ou mudança por contigüidade, no sentido de que são gerados no contexto sintático. (grifo nosso)

Para o autor, a metáfora seria, ainda, uma forma de processamento de informação, possibilitada graças ao que de mais produtivo temos enquanto ser humano: nossa capacidade de aproximar mentalmente funções e transportar um elemento de uma função mais recorrente, que não exige grande energia e esforço mental para ser reproduzida, para outra função mais complexa, mais abstrata e que exige maior esforço, mas é necessária. Lima-Hernandes \& Casseb-Galvão (2012) também evidenciaram toda a abrangência e importância fundamental desse processo: "Para além de se configurar como um mecanismo de solução de problemas ${ }^{30}$, a metáfora solda-se como uma questão de sobrevivência diária, representada pela forma produtiva de conseguir intentos”. Sem a metáfora, a comunicação humana, pelo menos do modo como a conhecemos, não existiria.

\footnotetext{
${ }^{29} \mathrm{Na}$ linguística, diferentemente do que ocorre na literatura, a metáfora e a metonímia não são figuras de linguagem ou formas de tornar o texto esteticamente mais elaborado. São mecanismos de renovação da língua.

30 Como postularam Heine, Claudi \& Hünnemeyer (1991:150).
} 
Ainda, tratando do conceito de metáfora e sua atuação no emprego de elementos linguísticos, Votre (1999) propõe o princípio de extensão imagética instantânea. Segundo esse princípio, a faculdade da metáfora opera de modo instantâneo, disponibilizando, no momento da interação verbal, todas as possibilidades e potencialidades na mente das pessoas que interagem na comunidade discursiva, fundamentadas no contexto situacional de cada interação.

Durante a projeção metafórica, do ponto de vista do interlocutor, é inevitável a ocorrência de usos ambíguos. A ambiguidade, que é caracterizada como algo negativo nos manuais sobre a boa redação, é, na linguística, o resultado de uma etapa ainda confusa (ou não claramente percebida) da mudança linguística que está sendo processada, constituindo-se em um efeito de sentido causado pelos deslizamentos.

Já o processo metonímico atuará quando algum segmento codificado sintaticamente, de tão recorrente, passar a não vir expresso na fala do indivíduo. $\mathrm{O}$ elemento elidido tem seu sentido incorporado por outro na cadeia sintática. Caso esse implicitamento também passe a ser recorrente na fala de outras pessoas, há grande chance de ocorrer o processo de reanálise. Lima-Hernandes e Casseb-Galvão (2013:5) argumentam nesse sentido, apresentando-nos um interessante exemplo: o cumprimento "bom dia", tão recorrente em nossa língua. Essa ação é repetida por inúmeros usuários e codifica o que sintaticamente foi no passado equivalente à construção "Eu lhe desejo um bom-dia". O costume de se repetir todos os dias essa informação faz com que esta deixe de ser requerida, porque facilmente inferível, e, gradativamente, a cadeia sintática sofrerá erosão. O que se constituía uma expressão de caráter volitivo passa a sinalizar simplesmente um cumprimento. Em suma, uma informação só é elidida, porque se torna bastante previsível - e é esperado que todos sejam capazes inferencialmente de preencher a lacuna. Com o passar do tempo, gerações futuras podem não mais sentir falta dessa informação nem inferir o que foi elidido no passado porque a reanálise terá se manifestado.

Outro importante assunto relacionado à gramaticalização é o da correlação frequência de uso e derivação categorial, que instaurou polêmica discussão entre os linguistas. Esta correlação é vinculada à discussão das variáveis que podem interferir no estudo de rotas de gramaticalização. Categoricamente, não se percebe uma correspondência satisfatória entre alta frequência de uso e construções que estão sendo 
gramaticalizadas, já que itens inovadores assumem baixa frequência no discurso. Talvez valesse a pena discutir frequência num quadro mais restrito de estratificação diastrática.

Algumas conclusões podem ser tiradas a partir dos fatos de que os itens gramaticais são mais frequentes do que os lexicais e são também mais abstratos, mais generalizados do que esses últimos ${ }^{31}$. Uma das conclusões é a de que a repetição é um elemento motivador do processo de abstratização. Outra conclusão é a de que a repetição é um dos efeitos da gramaticalização, já que quanto mais gramatical for um item mais funcional ele se torna e, em consequência, mais repetido. Portanto, a relação entre frequência de uso e gramaticalização seria a seguinte: "o aumento da frequência é resultado e facilitador do processo de gramaticalização.” (LIMA-HERNADES, 2006). O Grupo de Pesquisa "Linguagem e Cognição ", ao qual este trabalho se vincula, acompanhou de perto processos relacionados à questão da repetição. Verificamos, com base em Haiman (1994), que quatro estágios associam-se à gramaticalização:

1. habituation or adaptation: a decline in the tendency to respond to stimuli that have become familiar due to repeated or persistent exposure. ${ }^{32}$ (HAIMAN, 1994:7);

2. automatization (automatização) (HAIMAN, 1994:8): processo que tem como efeito o uso de palavras em bloco em determinado contexto. A repetição gera autonomia do item, cujo efeito é o enfraquecimento dos componentes da construção ou a perda ${ }^{33}$, por parte desses, de associação com outros usos desse mesmo item. Se um mesmo padrão de inferência ocorre frequentemente com uma construção em um contexto particular, essa inferência pode se tornar parte do sentido dessa construção.

3. phonological reduction ${ }^{34}$ : the standard model of erosion whereby morphemes are reduced, first to bound affixes, then to phonemes, and finally to silence (...). Sounds now meaningless may have evolved originally from meaningful morphemes ${ }^{35}$. (HAIMAN, 1994:9).

\footnotetext{
${ }^{31}$ Conjunções e preposições, por exemplo, são bem mais frequentes na língua do que elementos lexicais, além de mais abstratas e generalizadas, uma vez que estabelecem ligação, respectivamente, entre inúmeras sentenças e palavras.

${ }^{32}$ Habituação ou adaptação: um declive na tendência a responder a estímulos que se tornaram familiares devido à exposição repetida ou persistente. (tradução sugerida)

${ }^{33}$ Haiman fala em "perda", entretanto, é importante ressaltar que o presente trabalho considera necessário cuidado com o emprego desse termo, uma vez que acredita que, na língua, não se perde nada que seja útil ou funcional.

${ }^{34}$ Temos como exemplo o caso de be going to, que através do processo de redução, transformou-se em be gonna.

35 Redução fonológica: o modelo padrão de erosão, segundo o qual morfemas são reduzidos, primeiramente, para juntar-se a afixos, depois a fonemas, e, finalmente, ao silêncio. Sons hoje sem significado podem ter evoluído originalmente de morfemas significativos. (tradução sugerida)
} 
4. emancipation (emancipação) (HAIMAN:1994:14): repetidas em determinado contexto, algumas palavras podem se tornar independentes de suas associações instrumentais e contextuais.

Mas essa percepção não é nova na linguística. Já em Meillet (1958 [1912]:135) havia a compreensão de que " $A$ chaque fois qu'um élément linguistique est employé, sa

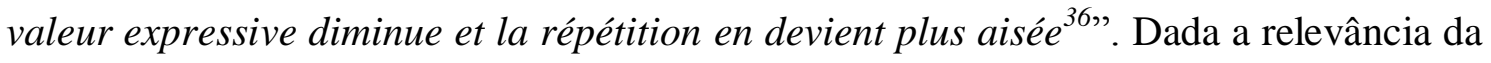
questão da frequência, ela será adotada como forma de controle também nesta dissertação.

Ao longo do processo de mudança linguística, a passagem de um estado para o outro não faz com que todos os traços do estado anterior sejam perdidos ou substituídos por traços do estado atual. Quando formas que estavam em um estado X passam para um estado Y, é possível observar que algo do estágio X é mantido no estágio Y. E é justamente esse traço ou "rastro" que permite estabelecer uma associação entre esses dois estágios. Essa sensação de gradualidade na mudança proporciona o equilíbrio necessário ao sistema.

Quando Sweetser (1988) empregou o termo “bleaching” (desbotamento) para se referir às perdas sofridas por uma construção durante o processo de mudança de um domínio para outro estava demonstrando a consciência de haver um processo gradual de mudança em curso. Traugott (1982), focalizando o rótulo em si, colocou-se contra, argumentando que a ideia de perda seria questionável, já que ganhos e manutenção de traços também poderiam ocorrer. Sweetser, no entanto, esclareceu a decisão pelo rótulo em falta de outro melhor, mas seus argumentos, na verdade, já pressupunham a ideia de necessidade de novos significados em decorrência do "abandono", e não perda, de alguns significados. Em alguns casos, essa necessidade representa, inclusive, uma identificação de grupo, ou seja, a expressão é usada entre falantes vinculados a uma determinada faixa etária ou determinado nível de escolarização, enfim, determinado grupo social, mas é rejeitada por falantes associados a outros grupos. O processo de gramaticalização estaria, então, sempre ligado à ideia de equilíbrio, já que, de acordo com a proposta de Sweetser, "perdas" seriam sempre compensadas por ganhos.

É uma questão de sobrevivência. Mesmo nas situações aparentemente mais drásticas de mudança linguística, remanesce o equilíbrio, que se apresenta mais intenso

\footnotetext{
${ }^{36}$ A cada vez que um elemento linguístico é empregado, seu valor expressivo diminui e sua repetição o torna cada vez mais comum. (tradução sugerida)
} 
no momento da interação entre os indivíduos que integram uma comunidade linguística, ainda que com histórias ou traços sociais distintos. É esse o momento no qual as diferenças são colocadas em confronto. O emissor precisa fazer-se entender e a sua intenção precisa ser compreendida adequadamente pelo receptor. Nessa busca contínua por identificar a intenção do outro, vale destacar, são acionados processos inferenciais com base em cenários ilocucionários com os quais o indivíduo já teve contato e que fazem parte de sua memória de longo-termo ${ }^{37}$ (Mendonza \& Baicchi, 2007:97). A interação social reveste-se, desse modo, e a cada momento, de seu caráter de troca, um espaço de gradualidades e mediação por excelência. $\mathrm{O}$ reconhecimento dessa gradualidade pode ser ilustrado com a presença, no sistema linguístico, de formas idênticas com funções diversas. É a persistência de traços a garantia da gradualidade e da sobrevivência num momento de renovação. Como afirma Paul (1966:27), ao tratar da mudança linguística:

\begin{abstract}
Em cada modificação só se pode dar um pequeno passo. Como seria possível doutra maneira, se ela surge sem se contar e, como acontece na maioria dos casos, sem que aquele que fala se aperceba de que produz qualquer coisa que não existia antes?
\end{abstract}

Pelo fato de as línguas, ao mesmo tempo, exibirem regularidade e variação, Bybee (2010) postula que uma teoria da linguagem poderia focar os processos dinâmicos que criam as línguas e fazem delas sistemas adaptativos complexos, que exibem variação e gradiência. Essa última refere-se à transição, à mudança gradual que dificulta a distinção das categorias linguísticas.

Concebendo a língua exatamente dessa forma dinâmica, Hopper (1991:22) postulou cinco princípios através dos quais se observaria a gradualidade típica do processo de gramaticalização:

(1) Layering: "Within a broad functional domain, new layers are continually emerging. As this happens, the older layers are not necessarily discarded, but may remain to coexist with and interact with the newer layers."

(2) Divergence: "When a lexical form undergoes grammaticization to a clitic or affix, the original lexical form may remain as an autonomous element and undergo the same changes as ordinary lexical items".

\footnotetext{
${ }^{37}$ Lima-Hernandes \& Casseb-Galvão (2012) afirmam, ainda, que "a bagagem pragmática é a que garante a melhor interpretação". Ou seja, quanto mais uso o sujeito fizer da língua, melhor lidará com ela, mais capaz será de compreendê-la e usá-la eficazmente.
} 
(3) Specialization: "Within a functional domain, at one stage a variety of forms with different semantic nuances may be possible; as grammaticization takes place, this variety of formal choices narrows and the smaller number of forms selected assume more general grammatical meanings."

(4) Persistence: "When a form undergoes grammaticization from a lexical to a grammatical function, so long as it is grammaticaly viable some traces of its original lexical meaning tend to adhere to it, and details of its lexical history may be reflected in constraints on its grammatical distribution".

(5) De-categorialization: "Forms undergoing grammaticization tend to lose or neutralize the morphological markers and syntactic privileges characteristic of the full categories Noun and Verb, and to assume attributes characteristic of secondary categories such as Adjective, Participle, Preposition, etc. ${ }^{, 38}$

Alguns desses princípios serão considerados, no presente trabalho, como passo metodológico para a recolha de indícios do possível processo de gramaticalização ao qual a construção quase (que) estaria submetida.

Pensando em um dos contextos específicos de uso da língua ao qual esta pesquisa se dedicou - produção de redações dissertativas de candidatos ao vestibular -, é importante ressaltar tratar-se de um locus no qual tradição e renovação se fazem presentes. Como consideramos gramaticalização como processo de renovação linguística, há a necessidade de se definirem como constituinte do corpus produções linguísticas mais suscetíveis - dizemos "mais", pois, afinal, todas o são - a se comportarem como "berços" de renovações. Ao escrever uma redação em um exame de vestibular ou o resumo de sua tese ou dissertação, o escrevente está atuando como emissor em uma interação pouco espontânea que exerce grande pressão sobre ele. A necessidade de transmitir sua intenção do modo mais claro possível, de fazer-se

${ }^{38}$ Estratificação: em domínio funcional amplo, novas camadas estão continuamente emergindo. Quando isso acontece, as camadas velhas não são necessariamente descartadas, mas podem permanecer a coexistir e interagir com as novas camadas.

Divergência: quando um elemento lexical submete-se à gramaticização para um clítico ou afixo, a forma lexical original pode permanecer como um elemento autônomo e submeter-se às mesmas mudanças que os itens lexicais comuns.

Especialização: dentro de um domínio funcional, em um estágio, a variedade de formas com nuances semânticas diferentes é possível; quando a gramaticização ocorre, essa variedade de escolhas formais se restringe e um menor número de formas selecionadas assumem significados gramaticais mais gerais.

Persistência: quando uma forma submete-se à gramaticização de uma função lexical para uma gramatical, assim que se torna gramaticalmente viável, alguns traços de seu significado lexical original tendem a aderir a ela, e detalhes de sua história lexical podem ser refletidos em restrições em sua distribuição gramatical.

Decategorização: formas submetidas à gramaticização tendem a perder as marcas morfológicas e a independência sintática características das categorias plenas de substantivo e verbo, e a assumir atributos de categorias secundárias, como adjetivo, particípio, preposição, etc. (tradução sugerida) 
entender, são fatores que exigem que ele se manifeste segundo um padrão que garanta a sobrevivência da tradição. No entanto, o candidato/autor (pelo menos os mais bem avaliados) sente-se impelido a ser criativo, a fugir do lugar comum, mas não a ponto de ignorar a necessidade do exato equilíbrio entre a tradição e a renovação. Esse equilíbrio deve estar presente, na realidade, em toda e qualquer interação verbal em que o resultado é a intercompreensão.

Enquanto forças impelem o usuário da língua a ser expressivo e inovador, forças contrárias impõem regras de intercompreensão. Tudo o que é comunicado passa por um processo de seleção baseado no conhecimento que o locutor imagina que seu interlocutor possua. Clareza e objetividade são limitadas pela necessidade de certa dose de "cumprimento" da tradição. Assim, o equilíbrio deve sempre ser mantido sob pena de provocar incompreensões comunicativas.

O produto desse processo de elaboração pode ser fonte interessante para identificar deslizamentos funcionais e também para reflexões sobre motivações pragmáticas. Justifica essa concepção o fato de que, no deslizamento de um estado para outro, ocorre um rearranjo de todas as capacidades cognitivas. Desse modo, a gramaticalização não pode mais ser interpretada como um processo de mudança puramente linguístico ou gramatical. Ela é um processo motivado por forças pragmáticas e também pela resposta cognitiva a essas mesmas forças.

A pressão exercida por impulsos pragmáticos, os quais exigem soluções criativas por parte dos locutores para problemas comunicativos, conduz à mobilização de macroconstruções produtivas. Para resolver um impasse na situação comunicativa, recorre-se a macroconstruções já existentes na língua e que são mobilizadas a fim de preencher determinadas "lacunas" presentes na bagagem pragmática do locutor, o qual procura uma solução para sua necessidade de expressar algo que, para ele, precisa ser dito de maneira diferente à habitual. Daí ser necessário tratar também da gramática de construções.

\subsection{Gramática de construções}

Teóricos da gramaticalização, mais recentemente, passaram a se dar conta de que o conceito de construções oferece respostas mais adequadas para alguns fenômenos estudados. É fácil compreender que a mudança não é simplesmente movida pela 
criatividade, mas também pela tradição, pelo que de mais produtivo está em curso na língua. Apesar de gramaticalização pressupor "construcionalização", os dois processos precisam ser mantidos separadamente, já que nem todas as construções se gramaticalizam. O conceito de "construção" aqui admitido define-a como um esquema que une forma e função, constituindo-se parte do nosso conhecimento sobre a língua. Quando produzimos um enunciado, selecionamos, assim, itens lexicais e construções as quais são mais gramaticais - armazenadas no léxico.

Inicialmente $^{39}$, linguistas que não aceitavam - ou não eram aceitos - pelos grupos formalistas declaravam-se ou funcionalistas ou cognitivistas. No início do século XXI, surgiu uma abordagem alternativa, que favoreceu a convergência dos argumentos desses estudiosos, até então separados por suas teorias: a gramática de construção. Seu ponto principal de distinção em relação à gramática gerativa é a definição de que a sintaxe e a semântica não são separadas em componentes autônomos, mas unidas como um conjunto estruturado formado por unidades simbólicas convencionais.

Passou-se a questionar de que modo essa nova perspectiva, que funcionava como uma abordagem geral à língua, poderia ser útil à teoria da gramaticalização e vice-versa. Estava claro que não seria possível apenas fundir as duas disciplinas. Bybee (2003a:145), então, caracteriza gramaticalização como a criação de novas construções e propõe que o principal questionamento da teoria da gramaticalização seria: como as línguas adquirem gramática? Ou, melhor, como as línguas adquirem construções? Esse vem justamente a ser o leitmotiv da gramática de construção.

Hopper e Traugott (2003:18) referem-se ao termo "construções" ao definir gramaticalização como: "the change whereby lexical items and constructions come in certain linguistic contexts to serve grammatical functions and, once grammaticalized,

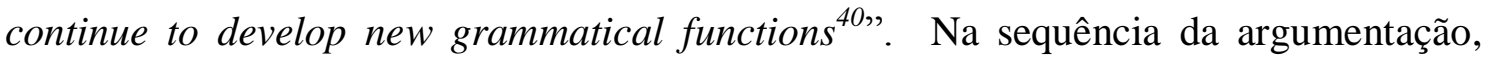
Traugott (2003:645) detalha esses contextos linguísticos, que seriam: "highly constrained pragmatic and morphosyntactic contexts ${ }^{41,}$, retomando o estágio de

\footnotetext{
${ }^{39}$ É importante ressaltar que a Linguística Funcional Centrada no Uso, admitida pela presente dissertação, não faz uma distinção rígida entre léxico e gramática, os quais são entendidos como parte de um continuum que coloca em movimento palavras e sequências maiores. A diferença entre construções lexicais e construções gramaticais reside, desse modo, no grau de complexidade interna de cada uma delas, sendo que a fronteira entre ambas é difusa e pode ser apreendida mais nitidamente via sintaxe.

${ }^{40}$ A mudança, em que itens lexicais e contruções vêm a servir, em certos contextos linguísticos, a funções gramaticais e, uma vez gramaticalizados, continuam a desenvolver novas funções gramaticais. (tradução sugerida)

${ }^{41}$ Contextos morfosintáticos e pragmáticos altamente restritos. (tradução sugerida)
} 
especialização proposto por Hopper (1991:22), já exposto na presente dissertação. Entretanto, uma nova abordagem é dada a esses contextos, que passam a ser, eles mesmos, relacionados à noção de construção. Bybee (2003b:153) define um dos aspectos da gramaticalização como "process of automatization of frequently occuring sequence of linguistic elements ${ }^{42}$ " e, por fim, afirma ser a gramaticalização um processo que ocorre no contexto de uma construção específica, ou melhor ainda, o processo no qual uma construção, composta por itens lexicais específicos, torna-se gramaticalizada. Claramente, a abordagem é mais voltada a processos cognitivos do que, no caso de Traugott, ao método de apreensão da mudança. Chegamos, desse modo, ao que nos inspirou a uma nova maneira de encarar a gramaticalização: a ideia de habituação conformada em termos de construção. E essa construção manifesta , por sua vez, "an automated, routinized chunk ${ }^{43}$ of language that is stored and activated by the language

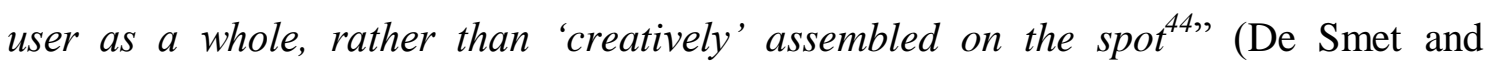
Cuyckens, 2007:188) ${ }^{45}$. E passamos a defender, com base em Traugott (2008) e Bybee (2003b), que a construção é o locus da inovação e que, quando determinada inovação é convencionalizada por um conjunto de usuários da língua, tem-se a mudança linguística.

O percurso da gramaticalização poderia ser, então, resumido nos seguintes passos:

1. uma construção tem seu emprego expandido a uma nova função, codificada, anteriormente, por outra construção - ambas começam, então, a concorrer entre si no desempenho dessa função;

2. a "antiga" construção deixa de codificar essa função ou é marginalizada a ponto de não mais concorrer de forma significativa com a construção que teve seu uso expandido - neste estágio, essa última já se tornou convencionalizada nessa função, que passa a ser uma de suas funções "normais";

\footnotetext{
${ }^{42}$ Processo de automatização de sequência de elementos linguísticos de ocorrência frequente. (tradução sugerida)

${ }^{43}$ Segundo Bybee (2010:7), "chunking is the process by which sequences of units that are used together cohere to form more complex units. (...) Repeated sequences of words (or morphemes) are packaged together in cognition so that the sequence can be accessed as a single unit."

${ }^{44}$ Um chunk de linguagem automatizado e rotinizado, que é armazenado e ativado como um todo pelo usuário da língua, em vez de montado "criativamente" no local (da interação verbal). (tradução sugerida)

45 Assim, durante a interação, o usuário da língua aciona o chunk, que está armazenado como um todo, um "bloco inteiro". Ele não "junta" os pedaços da construção para poder montá-la e empregá-la no momento do discurso. Essa já está montada e armazenada, pronta para ser acionada se o contexto a requerer.
} 
3. a "nova" construção sofre mudanças em sua forma gramatical e em seu comportamento de acordo com a nova função que assumiu - essas mudanças se manifestam na sintaxe, na morfologia e na fonologia e só ocorrem na construção nos contextos em que ela é empregada desempenhando essa função.

O problema é saber qual a abrangência desse processo. Essa foi, aliás, outra questão que se colocou como polêmica entre os estudiosos da gramaticalização também no início deste século. Uma vez que seu nome passou a ser utilizado, em um número cada vez maior de trabalhos, como um termo que abrangesse todo e qualquer tipo de mudança gramatical, instaurou-se a necessidade de realização de um recorte. Noël, nesse sentido, afirmou que:

Some of those who do apply the term grammaticalization consider every emergence of a construction to be grammaticalization, thereby subscribing to the most inclusive conception of the phenomenon, broader even than what grammaticalization theorists consider to be a broad stance ${ }^{46}$. (NOËL, 2007:191)

A principal origem do problema teria sido a elevação do conceito de gramaticalização ao status de "criadora da gramática" per si. Essa ampliação do conceito conduz à errônea classificação de uma série de diferentes processos de mudança gramatical sob o rótulo da gramaticalização. Para abordá-los brevemente, vamos tratar de dois dos mecanismos motivadores da mudança linguística: a analogia e a reanálise.

A analogia, como vimos anteriormente, é inerente ao ser humano. Trata-se de um processo constantemente mobilizado pela mente humana para resolver problemas diversos e aprender. Esse processo seria especializado em replicar padrões, por isso não criaria gramática, mas extensões de padrões operantes na língua. Assim, corresponderia a uma "equação" do tipo: A:B::C:D, em que D seria a forma resultante do processo de analogia. Um exemplo prático seriam as analogias realizadas por crianças em processo de aquisição da língua materna, que as levariam a empregar formas como fazi na tentativa de expressar a terceira pessoa do verbo fazer no tempo pretérito perfeito do modo indicativo. Por analogia aos verbos regulares - o padrão operante na língua - que,

\footnotetext{
${ }^{46}$ Alguns daqueles que empregam o termo gramaticalização consideram toda emergência de uma construção como gramaticalização, concordando, assim, com a concepção mais inclusiva do fenômeno, ainda mais ampla do que a que os teóricos de gramaticalização consideram que seja uma postura ampla. (tradução sugerida)
} 
nesse tempo verbal, nesse modo e na primeira pessoa do singular, apresentam as terminações "ei", caso sejam da primeira conjugação, e "i", sendo da segunda ou terceira conjugações, aquele que está em processo de aquisição da língua acaba por chegar à forma fazi. Apesar de não termos um resultado coerente com o padrão normativo, o processo de analogia agiu de modo perfeito apresentando uma solução lógica para o problema comunicativo. A criança realizou sozinha, a partir de um padrão operante na língua, um processo completo de analogia ${ }^{47}$.

Diferentemente da analogia, a reanálise, outro mecanismo motivador da mudança linguística, permite a criação de novas formas gramaticais, à medida que, gradualmente, são "alargadas" as fronteiras de constituintes em uma expressão, resultando na classificação de uma forma como pertencente a uma categoria diferente da original. Normalmente, a reanálise incorpora o contexto de uso, tal como demonstrou Lima-Hernandes (2008) com a expressão risco de vida.

Hopper \& Traugott (1993:61) nos apresentam o interessante exemplo da atuação da analogia e da reanálise na gramaticalização do verbo auxiliar be going to do inglês, que se gramaticalizou na forma gonna. Em estágio inicial, os verbos be e going, utilizados em expressões como be going (verbo direcional) to visit Bill, sofrem reanálise, passando a constituir, juntos, o verbo auxiliar be going to (indicativo de tempo futuro) seguidos de um verbo de ação. No estágio seguinte da mudança, o verbo auxiliar passa a ser empregado, por analogia, junto a outros verbos, não só aqueles indicadores de ação, como em [be going to] like Bill. Por fim, no último estágio do processo de gramaticalização, o verbo auxiliar é reanalisado na forma gonna: [gonna] like/visit Bill.

A analogia e a reanálise agem, portanto, de forma direta no processo de gramaticalização, mas são - é preciso destacar - fenômenos independentes, pois nem sempre, ao sofrer um desses processos, uma categoria lexical torna-se gramatical ou ainda mais gramatical. Logo, analogia e reanálise não definem a gramaticalização, são apenas processos que podem vir a atuar, como no exemplo citado, em que elementos mais independentes - be e going - se tornam menos independentes - [be going to], constituindo-se em um caso clássico de gramaticalização. Essa informação é também referendada por Meillet (1958 [1912]:133):

\footnotetext{
${ }^{47} \mathrm{O}$ funcionamento da analogia como precursora de uma mudança linguística segue trajeto semelhante.
} 
Tandis que l'analogie peut renouveler le détail des formes, mais lasse le plus souvent intact le plan d'ensemble du système existant, la 'grammaticalisation' de certains mots crée des formes neuves, introduit des catégories qui n'avaient pas d'expression linguistique, transforme l'ensemble du système. Ce type d'innovations résulte d'ailleurs, comme les innovations analogiques, de l'usage qui est fait de la langue, il en est une conséquence immédiate et naturelle. $^{48}$

Qual seria, então, a abrangência desse processo de gramaticalização? O que definiria a fronteira entre o que podemos classificar como um caso de gramaticalização e o que consiste em outro tipo de mudança linguística ou ainda apenas na atuação de determinados mecanismos linguísticos? Hopper \& Traugott (2003:24) afirmam que "how far we shall be prepared to extend the notion of 'grammaticalization' will be determined by the limits of our understanding of what it means for a construction to be 'grammatical' or have a grammatical function. ${ }^{49 "}$ A gramaticalização é o nome que se dá ao processo através do qual uma construção se torna gramatical, ou mais gramatical. A extensão do conceito dependerá do entendimento que tivermos do que seja "gramatical" ou "assumir uma função gramatical". Essa classificação, naturalmente, pode ser discutível.

Consideramos importante, neste sentido, destacar que não há efetivamente uma dicotomia entre léxico e gramática. Ao categorizar uma forma como lexical ou gramatical, deve-se pensar em um continuum, não em uma divisão em componentes separados. Bybee (2010:6) a esse respeito declarou que "If language were a fixed mental structure, it would perhaps have discrete categories; but since it is a mental structure that is in constant use and filtered through processing activities that change it, there is variation and gradation ${ }^{50,}$. O fato de toda forma ser [+ lexical] ou [+gramatical] dentro de um continuum permitiria falar em variação e gradação. Essa ideia nos conduz ao que Langacker tratou como transição e dinamicidade:

\footnotetext{
48 Enquanto a analogia pode reconfigurar o detalhe das formas - ainda que, mais frequentemente, deixando intacto o plano do conjunto do sistema existente - a "gramaticalização" de certas palavras cria formas novas, introduz categorias para as quais não havia qualquer expressão linguística e transforma o conjunto do sistema. As inovações desse tipo, aliás, assim como as analógicas, resultam do uso que se faz da língua - da qual elas são consequência natural e imediata. (tradução sugerida)

49 O quão preparados nós devemos estar para estender a noção de "gramaticalização" será determinado pelos limites de nosso entendimento do que significa para uma construção ser "gramatical" ou ter uma função gramatical. (tradução sugerida)

${ }^{50}$ Se a língua fosse uma estrutura mental fixa, ela teria, talvez, categorias discretas, mas já que é uma estrutura mental que está em constante uso e é filtrada através das atividades de processo que a mudam, há variação e gradação. (tradução sugerida)
} 
As an element becomes grammaticized, it therefore moves along this continuum rather than jumping from one discrete component to another, and it undergoes a change of meaning rather than becoming meaningless ${ }^{51}$. (LANGACKER, 1990:16)

A despeito, no entanto, de tantos encaminhamentos superficialmente divergentes, a maioria dos funcionalistas que lidam com o processo de gramaticalização admite, com Noël e Heine, que alguns mecanismos envolvidos no processo auxiliam também na delimitação da abrangência. Ambos retomam ideias de vários das postulações dos autores aqui explanados, mas permitem, de forma sumária, identificar os limites da análise. Em Heine, lemos quatro processos::

i. desemanticization (or "bleaching", semantic reduction): loss in meaning content;

ii. extension (or context generalization): use in new context;

iii.decategorialization: loss in morphosyntactic properties characteristic of the source forms, including the loss of independent word status (cliticization, affixation);

$i v$. erosion (or "phonetic reduction"), that is, loss in phonetic substance ${ }^{52}$. (HEINE, 2003:579)

E em Noël, o termo schematization orienta o foco de atenção do analista:

On the one hand, there is the development through which certain structural patterns acquire their own meanings, so that they add meaning to the lexical elements occurring in them. This kind of construction formation (or constructionalization) leads to partially or fully schematic constructions, and I will henceforth call it schematization. On the other hand, patterns that have acquired meaning can be subject to semantic change, and one possible change is move towards the grammatical end of the meaning continuum. This is grammaticalization. Both process result in new constructions (new pairings of form and meaning), but only the products of the latter can be guaranteed to have a "truly" grammatical meaning". (NOËL, 2007:192)

\footnotetext{
${ }^{51}$ Quando um elemento se torna gramaticizado, ele se move ao longo de um continuum, ao invés de pular de um elemento discreto para outro, e ele se submete à mudança de significado ao invés de tornar-se não significativo. (tradução sugerida)

52 i. dessemanticização (ou desbotamento; redução semântica): perda de significado do conteúdo;

ii. extensão (ou generalização de contexto): uso em novo contexto;

iii. perda em propriedades morfossintáticas características das formas de origem, incluindo a perda do status de palavra independente (cliticização, afixação);

iv. erosão (ou redução fonética), isto é, perda em substância fonética. (tradução sugerida)

53 Por um lado, há o desenvolvimento através do qual certos padrões estruturais adquirem seus próprios significados, de modo que eles adicionam significado aos elementos lexicais que ocorrem no item. Esse tipo de formação de construção (ou construcionalização) conduz a construções parcialmente ou totalmente esquemáticas, e eu irei, portanto, chamá-lo de esquematização. Por outro lado, padrões que
} 
Para o autor, o rótulo "gramaticalização" não pode ser empregado a um processo em que não tenha ocorrido um deslizamento em direção ao polo [+gramatical] do continuиm que citamos anteriormente.

A incorporação da Gramática de Construções ao modelo de abordagem congnitivo-funcional de deve, em parte, à ideia de que a língua é organizada em uma complexa rede de construções, sendo estas, de acordo com Goldberg (2003), entendidas como pareamentos entre forma e significado, desde que ocorram com certa frequência. Assumir que palavras são construções pressupõe rever o conceito de gramaticalização, ampliando o conceito de item para dar conta de construções. Esses pareamentos também são guiados pela ritualização ou habituação.

\subsection{A ritualização}

A ritualização, um dos mecanismos propostos por Haiman (1994), estaria relacionada ao papel assumido pela repetição no processo de mudança linguística. $O$ termo, entretanto, já havia sido empregado por etologistas, como Tinbergen (1952) e Blest (1963), ao se referirem às ritualizações não linguísticas presentes na criação de sinais entre os animais. Assim, por exemplo, o uivo de um lobo como uma preparação para agressão desenvolve-se em ou é substituído por um mesmo uivo como sinal de raiva. Em seu estudo sobre a comunicação entre as abelhas, Frisch (1967) demonstrou como o comportamento por elas desenvolvido quando estão à procura por locais de alimentos torna-se estilizado e evolui para a conhecida linguagem das abelhas, em que diferentes tipos de dança indicam a distância e a direção a serem percorridas até o alimento. Um sinal estilizado é necessário, pois é mais facilmente reconhecido e também reproduzido do que um gesto espontâneo. Como afirma Blest (1963:102), “in the course of evolution, both locomotory movements and acts (concerned with comfort, with heat regulation, and with the capture of prey) have been selected and modified to

adquiriram significado podem ser sujeitados à mudança semântica, e uma possível mudança é mover-se através do polo gramatical do continuum de significado. Isso é gramaticalização. Ambos os processos resultam em novas construções (novos pareamentos de forma e significado), mas apenas os produtos do último podem ser assegurados a terem "realmente" um significado gramatical. (tradução sugerida) 
produce signals ${ }^{54 "}$. Tanto etologistas quanto antropólogos têm utilizado o termo "ritualização" para descrever o processo através do qual ações filogeneticamente instrumentais são emancipadas de sua motivação primária e tornam-se livres para desempenhar uma função comunicativa. A ritualização é, nesse sentido, a aquisição de significado. Um ritual é assim identificado quando deixa de ser um ato puramente instrumental e se transforma em um sinal.

O processo de gramaticalização, segundo Haiman (1994), envolveria a ritualização das construções linguísticas, as quais, apenas através da repetição, podem transformar-se e assumir novas funções. A repetição, de acordo com o autor, é o motor que aciona a mudança ${ }^{55}$. Dado que a repetição de movimentos e ações permite ao indivíduo a economia de energia que seria gasta na busca de novas soluções específicas, motivações cognitivas estão também na base dessas decisões aparentemente individuais.

\section{Cognição}

Como postulam Furtado da Cunha, Bispo \& Silva (2013), “o termo cognição refere-se ao processo neurorracional de construção do conhecimento humano a partir da interação do organismo com o meio", ou seja, refere-se ao conjunto de operações mentais constituídas no contato do indivíduo com o ambiente físico e social em que vive. A cognição não é, pois, como defende Marcuschi (2005), um fenômeno meramente empírico nem meramente racional e mentalista, mas, sim, um fenômeno essencialmente social elaborado intersubjetivamente no plano discursivo.

A cognição, quando relacionada à gramática de construções, manifesta-se em operações dependentes das chamadas terras-raras (LIMA-HERNANDES, 2013), ou seja, da memória, da atenção e da interpretação de contextos específicos, os quais se revelam materialmente na frequência e produtividade de construções e funções neles envolvidas. $\mathrm{O}$ que permite ao linguista funcionalista e cognitivista, no processo de análise, ter acesso ao campo da cognição é a sua forma de "olhar" para o dado, forma

\footnotetext{
${ }^{54}$ No curso da evolução, tanto os movimentos locomotores quanto as ações (relacionados ao conforto, à regulação de calor e à captura de presas) têm sido selecionados e modificados para produzir sinais. (tradução sugerida)

${ }^{55}$ Essa ideia não é nova. Já em Vossler (1942), era um argumento forte para apoiar as ideias de seu contemporâneo Meillet.
} 
essa que não considera a sintaxe como o centro da atenção. Nessa abordagem, os domínios da sintaxe, da semântica e da pragmática são relacionados e interdependentes.

É por isso que assumimos, neste trabalho, que língua e também linguagem são formas de cognição e de processamento social, porque servem para realizações no plano individual e para realizar ações conjuntas. Perceber, portanto, como o indivíduo codifica uma intenção pressupõe recolher pistas de processamentos cognitivos na codificação linguística. É o que fazemos na análise dos padrões funcionais de quase (que) por nós identificados. Ocorre que as intenções de codificação não são imotivadas. Alguns princípios permitem identificar as motivações.

\subsection{Os princípios de iconicidade e de marcação}

Assentado na relação entre gramática e cognição, encontra-se o princípio da iconicidade. De acordo com esse princípio funcionalista, há uma relação motivada entre forma e significado, isto é, entre expressão e conteúdo. A discussão a respeito dessa motivação é bastante antiga, tendo dividido os filósofos gregos, na Antiguidade clássica, entre convencionalistas - para os quais, tudo na língua era convencional, resultante do costume e da tradição - e naturalistas - segundo os quais, a relação entre as coisas e as palavras que as designavam era natural, havia ocorrido por natureza ${ }^{56}$.

Essa questão é retomada ciclicamente nas teorias que emergem no campo da Linguística. No início do século XX, ela foi retomada por Saussure, que defendeu o convencionalismo, afirmando ser a língua dotada de um caráter arbitrário, não existindo uma relação natural entre significante (sequência de sons que formam o signo linguístico) e o significado (o que é evocado conceptualmente por essa sequência). E todos, em algum momento de seus estudos, propagaram a ideia de arbitrariedade do signo.

Logo depois, discutindo a mesma questão, assume a ribalta Peirce (1940). Esse filósofo, que fundiu, até certo ponto, as posições adotadas por convencionalistas e naturalistas defendia haver uma correlação transparente entre forma e função, mas esta não seria absoluta, e sim, moderada. O que ocorreria durante a codificação linguística

\footnotetext{
${ }^{56}$ Trata-se de mais um caso do debate tão recorrente - em filosofia, linguística, psicologia e outras áreas entre nature e nurture: debate acerca da importância relativa das faculdades inatas e das experiências pessoais, ou seja, o inato versus o aprendido.
} 
seria uma interação entre os chamados princípios icônicos, segundo os quais, a relação entre forma e conteúdo seria motivada, e os chamados princípios mais simbólicos, cognitivamente arbitrários, que se referem às regras convencionais.

Os funcionalistas, contudo, têm demonstrado que princípios simbólicos cognitivamente arbitrários são derivados da incapacidade (às vezes impostas pelo conhecimento científico de época) de identificar uma explicação mais plausível. Para esses estudiosos, todo traço da língua é reflexo de razões humanas. A estrutura da língua reflete, de alguma forma, a experiência do falante. Uma vez que a linguagem é inerente também à espécie humana, "a estrutura linguística revela as propriedades da conceitualização humana do mundo ou as propriedades da mente humana" (FURTADO DA CUNHA; COSTA; CEZARIO, 2003:30). Funcionalistas defendem, por essas razões, que na língua nada é arbitrário e que há uma relação motivada entre forma e significado, apreensível pelo princípio da iconicidade.

Essa relação, entretanto, nem sempre está “visível”. Principalmente na língua escrita, em muitos contextos, não há uma relação clara, transparente, entre expressão e conteúdo. Por esse motivo, a relação entre forma e significado soa, num primeiro momento, arbitrária. No entanto, o que de fato ocorreu foi que o significado original do elemento linguístico se perdeu total ou parcialmente da consciência do usuário e se torna opaca para o analista. Um exemplo é a construção "entretanto", que, hoje em dia, tem um significado adversativo, totalmente distinto de seu significado etimológico, referente ao interior de algum espaço físico ou de algum espaço no tempo (MACHADO, 1967). Essa sinalização não comprometida perdeu-se na trajetória de mudança da construção e deu lugar a uma codificação de envolvimento do emissor. Por conseguinte, há contextos em que a codificação morfossintática é opaca em termos da função que desempenha. Se não é observável a iconicidade em uma forma, é porque a relação forma-conteúdo se desfez devido às pressões diacrônicas, que atuam tanto na forma - a qual sofre erosão pelo atrito fonológico - quanto na função - que é constantemente alterada pela surgimento de novas necessidades comunicativas e pela consequente elaboração criativa. Ambas as pressões geram ambiguidades, uma vez que os resultados consistem em uma forma desempenhando várias funções e várias formas desempenhando uma mesma função. Apesar da opacidade, a iconicidade é um princípio que permite exercitar a busca de explicações históricas e etimológicas da construção, como faremos posteriormente com a construção quase. 
Os estudos linguísticos que envolveram o princípio de iconicidade permitiram em suas análises e encaminhamentos verificar que alguns subprincípios fortalecem-se enquanto métodos de identificação de motivações contextuais. O subprincípio da quantidade, segundo o qual, quanto maior, mais relevante - o que, muitas vezes, está relacionado à previsibilidade - for a quantidade de informação a ser transmitida ao interlocutor, maior será a quantidade de forma a ser utilizada em sua codificação morfossintática favorece lidar com forças de orientação da atenção de interlocutores. Desse modo, tudo aquilo que for mais simples e esperado, já previsto pelos usuários da língua, será expresso com o mecanismo morfológico e gramatical menos complexo, receberá menor codificação; ocorrendo o oposto com informações imprevisíveis, que receberão, por sua vez, codificações maiores (com maior quantidade de forma) ou mais complexas, embora de mesmo tamanho. Então, o que está em jogo não é somente tamanho formal, mas a complexidade do pensamento, que tende a refletir-se na complexidade de expressão, como postulou Givón (1983:18): "the more disruptive, surprising, discontinuous or hard to process a topic is, the more coding material must be assigned to $i^{57}$."

A opção pelo uso de uma construção em detrimento de outra jamais seria, portanto, arbitrária ou não carregada de significado. A escolha pelo uso da construção quase que em detrimento de sua possível concorrente - quase - manifestaria, hipotetizamos, a atitude do candidato de preocupar-se em transmitir conceitos e informações que sejam relevantes e imprevisíveis, visando ao desenvolvimento de uma dissertação criativa e, por consequência, com chances de ser bem pontuada pela banca examinadora.

Torna-se importante ressaltar que o reflexo mais geral da iconicidade na gramática é a correlação que se estabelece entre a baixa frequência de ocorrência de uma construção e suas marcações estrutural e cognitiva. Definindo o conceito de marcação, Givón (1995:28) apresenta os três critérios para se distinguirem categorias marcadas das não-marcadas:

a) Structural complexity: The marked structure tends to be more complex (or larger) than the corresponding unmarked one.

\footnotetext{
${ }^{57}$ Quanto mais perturbador, surpreendente, descontínuo ou difícil de processar é um tópico, mais material codificado deve ser atribuído a ele. (tradução sugerida)
} 
b) Frequency distribution: The marked category (figure) tends to be less frequent, thus cognitively more salient, than the corresponding unmarked category (ground).

c) Cognitive complexity: The marked category tends to be cognitively more complex - in terms of mental effort, attention demands or processing time than the unmarked one ${ }^{58}$.

O próprio autor atenta, entretanto, à necessidade de não se considerarem as categorias em termos binários, mas, sim, de adotar parâmetros de gradualidade, classificando construções como mais marcadas ou menos marcadas a depender do contexto de uso. Assim, uma construção pode ser macada, e chamar a atenção para si, se empregada num contexto atípico. Por isso Givón destaca o essencial papel desempenhado pelo contexto nesta classificação: "Markedness is a context-dependent phenomenon par excellence. The very same strucuture may be marked in one context and unmarked in another ${ }^{59}$." (GIVÓN, 1995:27).

O fato de uma construção ser mais marcada cognitivamente, ou seja, exigir maior esforço mental para ser processada, levará inevitavelmente a uma menor frequência de uso em contextos de uso mais geral. Assim, um adulto pode empregar como forma não-marcada uma construção que pode ser opaca à compreensão da criança, que a teria, então, como uma construção marcada. Adicionalmente, pelo subprincípio da quantidade, sabemos que uma informação mais complexa tende a ser codificada em uma construção também de maior complexidade. Bybee preferiria falar em usos problemáticos:

In general, lexical morphemes are less problematic than grammatical morphemes, exhibiting more regularity of form and meaning. However, there are still problematic lexical morphemes which change their meaning and nature depending upon the company they keep ${ }^{60}$.

(BYBEE, 2010:2)

58 a) Complexidade estrutural: a estrutura marcada tende a ser mais complexa (ou maior) do que a não marcada correspondente.

b) Distribuição da frequência: a categoria marcada (figura) tende a ser menos frequente, portanto, mais saliente cognitivamente, do que a categoria não marcada correspondente (fundo).

c) Complexidade cognitiva: a categoria marcada tende a ser mais complexa cognitivamente - em termos de esforço mental, demanda de atenção ou tempo de processamento - do que a não marcada. (tradução sugerida)

${ }^{59}$ Marcação é um fenômeno dependente do contexto por excelência. A exata mesma estrutura pode ser marcada em um contexto e não marcada em outro. (tradução sugerida)

${ }^{60}$ Em geral, morfemas lexicais são menos problemáticos do que morfemas gramaticais, exibindo maior regularidade de forma e significado. Entretanto, há morfemas lexicais problemáticos, os quais mudam seus significados e natureza dependendo da companhia que mantém. (tradução sugerida) 
O modo como estes três âmbitos - estrutural, pragmático e cognitivo - interrelacionamse é uma demonstração da motivação existente entre expressão e conteúdo defendida pelo funcionalismo, daí a necessidade de diálogo com a Ciência da Cognição.

\subsection{A Linguística Cognitiva}

A escolha do rótulo "Linguística Cognitiva" para nomear uma nova abordagem que surgia nos estudos linguísticos poderia gerar um grave engano: associá-la à gramática gerativa proposta por Chomsky, justamente pelo fato de este ter promovido uma guinada cognitivista em relação ao estruturalismo que o precedeu. Entretanto, no caso da Linguística Cognitiva, o termo "cognitiva" não apenas sinaliza que a língua é um fenômeno psicologicamente real e que a linguística é parte das ciências cognitivas, como também que o processamento e armazenamento de informação são conceitos fundamentais para a língua.

É relevante atentar para o fato de que os estudiosos ligados à Linguística Cognitiva defendem que princípios cognitivos gerais, e não apenas especificamente linguísticos, atuam na organização da linguagem e que esta não é, portanto, uma faculdade cognitiva autônoma. Martelotta (2008:62), dentre outros, assume essa posição:

(...) a linguagem reflete um conjunto complexo de atividades comunicativas, sociais e cognitivas, integradas com o resto da psicologia humana, isto é, sua estrutura é consequente de processos gerais do pensamento que os indivíduos elaboram ao criarem significados em situações de interação com outros indivíduos.

A linguística não se restringe somente ao conhecimento da língua - sendo este o foco da gramática gerativa. A língua é ela própria uma forma de conhecimento e deve ser assim analisada. Além disso, a gramática da língua é simbólica e nela o significado assume uma parte essencial.

O significado não deve ser entendido como um reflexo direto do mundo, mas sim, uma forma de configurá-lo. Pode-se dizer que o significado constrói o mundo, é uma construção cognitiva através da qual o mundo é apreendido e experienciado. Ele encarna uma perspectiva sobre o mundo. Desse modo, as palavras não contêm 
propriamente significado, mas orientam a construção do sentido ${ }^{61}$. Como afirma Paul (1966:25), “a organização corporal, a natureza ambiente, toda a cultura, todas as experiências e vivências, tudo deixou efeitos na língua, e que esta, portanto, observada deste ponto de vista, depende de todos os fatores imagináveis, dos mais variados".

Temos de lembrar, porém, que lidamos com um mundo em constante mudança. Os significados mudam a todo momento, uma vez que novas experiências e mudanças em nosso ambiente exigem que adaptemos nossa semântica às transformações das circunstâncias presentes. Impõe-se, assim, a necessidade de pensar-se na língua não como uma estrutura mais ou menos rígida, mas, sim, como uma estrutura flexível, como vínhamos sustentando no início deste capítulo. A Linguística Cognitiva concebe, então, o significado como construção mental em movimento contínuo de categorização e recategorização do mundo e o conhecimento que adquirimos, enciclopédico, uma vez que este também se acumula ao longo do tempo.

\subsubsection{O conhecimento enciclopédico}

A distinção entre as concepções de "conhecimento enciclopédico" e "conhecimento de dicionário" constitui-se sempre como questão para lexicólogos linguistas que trabalham com o significado das palavras - e lexicógrafos - profissionais que elaboram dicionários. Essa dicotomia, entretanto, tem sido questionada, e a Linguística Cognitiva tem admitido o conhecimento de dicionário como uma subparte do conhecimento enciclopédico.

Segundo a visão enciclopédica, os significados convencionalmente associados às palavras são abstrações criadas a partir de uma grande quantia de contextos de uso associados a um determinado item lexical, os quais se foram acumulando ao longo do tempo. A voz de Croft (2009:404), quando defende que o significado é enciclopédico, ganha eco quando assevera que " $a$ speaker's representation of the meaning of a word or construction is the totality of knowledge and experience of the situations for which that word/construction has been used ${ }^{62,}$.

\footnotetext{
${ }^{61}$ Ilustra muito bem essa ideia, a afirmação de Fauconnier (1997:1): “a linguagem é a ponta visível do iceberg da construção invisível do significado".

${ }^{62}$ Uma representação do significado de uma palavra ou construção para o falante é a totalidade do conhecimento e experiência das situações nas quais essa palavra/construção tem sido usada. (tradução
} 
Não há, desse modo, um significado fixo para cada item lexical. Diferentes sentidos irão derivar do significado dos elementos linguísticos circundantes a ele nos diversos contextos de uso. Considerando que as palavras ocorrem sempre em um contexto, o chamado significado convencional - aquele que é normalmente associado àquela determinada palavra - está intrinsicamente relacionado, na realidade, ao significado prototípico que surge a partir desses usos contextualizados. O significado convencional é visto, dessa forma, como abstração, enquanto o significado pragmático aquele associado a cada um dos diferentes contextos de uso e que, assim, sempre sofre variação - é considerado o significado real. Logo, o contexto orienta a construção do significado.

Não podemos perder de vista que a constituição do conhecimento enciclopédico é colocado em contato com os mais diferentes contextos de usos das construções linguísticas da língua ao longo do tempo. Assim, quando determinado enunciado é proferido, determinados sistemas de conhecimento são acessados pelo interlocutor, dependendo do contexto em que o enunciado ocorreu. As construções linguísticas não funcionam, portanto, como blocos que armazenam o significado, mas atuam como pontos de acesso a esses sistemas de conhecimento, construídos a partir de habilidades cognitivas e do contato com o mundo. Sendo assim, a realidade deveria ser entendida como resultado de capacidades cognitivas e, nesse sentido, ratificamos Geeraerts (2006:5): "Linguistic meaning (...) is encyclopedic and non-autonomous: it involves knowledge of the world that is integrated with our other cognitive capacities ${ }^{63 "}$.

\subsubsection{A realidade projetada}

Adotando um caminho diferente daquele percorrido pela Gramática Gerativa e por outras teorias que ignoraram a base corporal da experiência humana, a Linguística Cognitiva considera que é a partir das limitações do corpo que são definidas a experiência, a cognição e a realidade, conceito também defendido pela neuropsicologia.

Gallese (2004:5) a esse respeito postula que "our brain/body system models its interactions with the world ${ }^{64,}$. Em consonância com esse raciocínio, está o conceito de

\footnotetext{
sugerida)

${ }^{63}$ Significado linguístico (...) é enciclopédico e não autônomo: ele envolve conhecimento de mundo, o qual está integrado com nossas outras capacidades cognitivas. (tradução sugerida)

${ }^{64}$ Nosso sistema cerebral/corporal modela sua interação com o mundo. (tradução sugerida)
} 
neurônios espelhos (mirror neurons), trabalhados, dentre outros, por Gallese em boa parte de sua carreira. Trata-se de um neurônio que é ativado em dois contextos: quando um animal realiza um determinado ato e quando observa outro animal (normalmente da mesma espécie) a fazer o mesmo ato. Desta forma, o neurônio "imita" o comportamento de outro animal como se estivesse ele próprio realizando a ação. Estes neurônios já foram observados de forma direta em primatas, acreditando-se que também existam em humanos e em alguns pássaros. As células correspondentes são consideradas como uma das descobertas mais importantes da neurociência da última década, já que permitem alimentar um argumento de importância crucial no desenvolvimento humano: a imitação no momento de aquisição da linguagem.

$\mathrm{O}$ acesso à realidade total do mundo externo é limitado pela natureza da estrutura corporal. Humanos não possuem capacidade para, por exemplo, enxergar com facilidade à noite, ao passo que cascavéis e alguns outros animais realizam atividades noturnas. Diferentemente deles, humanos não conseguem detectar, através da visão, o calor emitido pelos corpos de outros seres. Ou seja, o aparato visual dos seres humanos - uma das características de sua estrutura corporal - limita sua experiência nesse sentido. Daí Geeraerts (2006:5) asseverar que "our organic nature influences our experience of the world, and this experience is reflected on the language we use ${ }^{65 \%} . \mathrm{O}$ pensamento é, assim, corporificado, no sentido de que a sua estrutura e sua organização estão diretamente associadas à estrutura do corpo, bem como às restrições de percepção e de movimento no espaço. Como postulou Lightfoot (1989:321), “an organism experiences the surrounding environment and selects relevant stimuli according to criteria that are already present internally ${ }^{66 "}$. Perspectiva esta fortemente defendida por etólogos como Lorenz e Tinbergen, cujos trabalhos demonstraram a concepção do ser humano como um ser biologicamente cultural e social, cuja natureza orgânica irá determinar o modo como a cultura será adquirida ${ }^{67}$.

Desse modo, a Linguística Cognitiva assume os pressupostos de que não há uma realidade objetiva a ser descrita pela linguagem. O que temos, segundo Jackendoff

\footnotetext{
${ }^{65}$ Nossa natureza orgânica influencia nossa experiência do mundo, e essa experiência é refletida na língua que usamos. (tradução sugerida)

${ }^{66}$ Um organismo experiencia o ambiente a sua volta e seleciona estímulos relevantes de acordo com critérios que já estão presentes internamente. (tradução sugerida)

${ }^{67}$ Alguns projetos do Grupo de Pesquisa Linguagem e Cognição têm investigado essa vertente, dentre os quais citamos Guerra $(2011 ; 2013 ; 2014)$.
} 
(1983), é uma realidade projetada, que se trata de uma construção da mente humana e que foi moldada através do que nossa estrutura corporal nos permitiu perceber no mundo e de como conceitualizamos a realidade à qual tivemos acesso. A perspectiva que temos do mundo é, pois, uma perspectiva particular dentre várias possíveis. Não é sem razão que Lakoff (1987) argumenta que o pensamento é "enraizado" no corpo, de modo que as bases do sistema conceptual humano são percepção, movimento corporal e experiências de caráter físico e social. A construção da realidade realizada pela mente humana não pode, por conseguinte, ser vista como autônoma. Ela é dependente da estrutura corporal e do modo como a esta é permitido interagir com o mundo externo físico e social. Similarmente, Croft (2009:397) defende esse raciocínio, afirmando que "Cognitive linguistics must reach out and embed itself in a more general socialinteractional model of language ${ }^{68}$ ". É necessário, pois, associar as dimensões cognitivas e as sociais da linguagem, principalmente porque muito do que temos são ferramentas derivadas de herança cultural.

\subsection{Tomasello: o salto qualitativo, a evolução cultural cumulativa e o reconhecimento de intencionalidade}

É pelo grande peso - já tão demonstrado nesta dissertação - exercido pelas motivações cognitivas nos processos linguísticos que tomamos como uma das leituras primordiais durante a fase inicial da pesquisa os textos produzidos por Michael Tomasello. Entender as especificidades apresentadas pelo processo de aquisição de linguagem humana colocou-se como tarefa essencial para que pudéssemos compreender os fundamentos das teorias propostas pelo autor a respeito da cognição humana. Discutiremos essa abordagem orientados por três aspectos relevantes para o encaminhamento desta dissertação: conhecimentos cumulativos, habilidades cognitivas e intencionalidade.

\subsubsection{O que nos difere?}

\footnotetext{
${ }^{68}$ Linguística Cognitiva deve estender-se e inserir-se em um modelo de linguagem social interacional mais geral. (tradução sugerida)
} 
Quando se pretende analisar a aquisição do conhecimento humano, um questionamento torna-se essencial: o que difere esta aquisição daquelas relativas às outras espécies? Ou seja, no que o tipo de aquisição por que passamos nos torna diferentes das demais espécies?

Para dar início à formulação de uma resposta aceitável para essas questões, torna-se necessário, primeiramente, que um enigma seja solucionado. Este consiste no seguinte: humanos e chimpanzés possuem em comum algo em torno de $99 \%$ de seu material genético ${ }^{69}$, sendo este o mesmo grau de parentesco de outros espécies irmãs, tais como leões e tigres, cavalos e zebras, ratazanas e camundongos. Entretanto, do ponto de vista da evolução, o tempo que nos separa de outros grandes macacos (seis milhões de anos) seria muito pouco para que os processos normais de evolução biológica que envolvem variação genética e seleção natural criassem, uma por uma, todas as habilidades cognitivas que nos diferem de outros primatas, ou seja, todas aquelas habilidades necessárias para que os humanos modernos inventassem e conservassem por gerações e gerações complexas aptidões e tecnologias no uso de ferramentas, complexas formas de comunicação e representação simbólica, e complexas organizações e instituições sociais. O enigma se reforça ainda mais se considerarmos algumas pesquisas atuais em paleontologia, segundo as quais os primeiros sinais de habilidades cognitivas únicas da espécie humana teriam surgido apenas no último quarto de milhão de anos com o moderno Homo sapiens.

Tomasello (1999) apresenta uma interessante solução para esse enigma: a transmissão sociocultural - um mecanismo biológico que, segundo o autor, funcionaria em escalas de tempo bem mais rápidas do que aquelas com as quais a evolução orgânica ocorre. Esse mecanismo consistiria basicamente na exploração por parte dos seres do conhecimento e das habilidades já desenvolvidas e estabelecidas por seus coespecíficos. Ora, essa habilidade estaria presente em diversas espécies, como as formigas, capazes de localizar alimento seguindo rastros de coespecíficos; os filhotes de rato, que só comem alimentos comidos por suas mães; os jovens chimpanzés, que aprendem dos adultos com quem convivem o manuseio das ferramentas. No que consistiria, então, o ponto diferencial entre outras espécies e a humana?

Tomasello (2003:5) define-o do seguinte modo: "as tradições e os artefatos culturais dos seres humanos acumulam modificações ao longo do tempo de uma

\footnotetext{
${ }^{69} \mathrm{E}$, ainda, compartilham algo em torno de $90 \%$ de seu material genético com os ratos.
} 
maneira que não ocorre nas outras espécies animais". Tal conceito é denominado "evolução cultural cumulativa" pelo autor. Desse modo, cada nova geração não teria de "começar do zero", pois várias habilidades e artefatos já teriam sido inventados, desenvolvidos e até mesmo aperfeiçoados ao longo do tempo pelos coespecíficos de gerações anteriores. Sendo assim, haveria sempre um conhecimento - na realidade, uma série deles - acumulado e pronto para ser transmitido e utilizado pelos coespecíficos mais jovens. Neste ponto, percebe-se ainda outra habilidade atinente à espécie humana: a de ser capaz de um tipo de aprendizagem social que possibilita a transmissão sociocultural efetiva. Sabe-se que muitos primatas não humanos produzem inovações, criações e novidades comportamentais inteligentes, que, entretanto, caso sejam assimiladas pelos coespecíficos, o serão de forma "frouxa", passível de extinção.

Essa seria garantida por uma forma de cognição social que, segundo Tomasello (2003:7), seria a grande responsável pelo salto qualitativo de nossa espécie ${ }^{70}$ : "a capacidade de cada organismo compreender os coespecíficos como seres iguais a ele, com vidas mentais e intencionais iguais às dele". Esse conceito torna-se claro quando pensamos na ideia de que, para ser capaz de aprender o uso convencional de uma ferramenta, um artefato ou um símbolo linguístico, a criança necessita, anteriormente, compreender o objetivo para o qual aquela pessoa está usando aquela ferramenta ou símbolo. Em outras palavras, ela tem de compreender o significado intencional ${ }^{71}$ do uso da ferramenta ou prática simbólica, o que pressupõe perceber o agente daquele uso como um ser intencional, igual a ela mesma, dotado de objetivos.

Atribuir a essa habilidade da espécie humana a responsabilidade pelo salto qualitativo por ela operado resolve o problema questionado anteriormente a respeito do tempo que seria insuficiente para o desenvolvimento de tantas habilidades cognitivas. Seria apenas uma a adaptação biológica que teria tornado possível esse desenvolvimento: a aprendizagem cultural - possibilitada pela capacidade do ser de identificar-se com o coespecífico, reconhecendo-o como um agente intencional, igual a

\footnotetext{
${ }^{70}$ Distinguindo-se das abordagens tradicionais da cognição humana, Tomasello não enfatiza a linguagem como o aspecto crítico para a evolução da cognição humana, mas, pelo contrário, sugere que ela é um produto desse tipo de cognição.

${ }^{71}$ Compreender a intenção por trás do uso será fundamental também para o aprendizado da língua. Uma construção linguística só é efetivamente aprendida por um indivíduo, quando este compreende seu significado intencional, a intenção do falante/escritor, os objetivos que pretende atingir, ao empregar aquela construção. Reconhecer as intenções por trás dos elementos linguísticos é também um ótimo caminho para o trabalho com as classes de palavras em sala de aula. Segundo Tomasello (2003), a compreensão da intenção comunicativa é uma condição necessária para a aquisição da linguagem.
} 
ele mesmo - que poderia ter acontecido em qualquer momento da evolução humana, até mesmo bastante recentemente.

O que ocorre com primatas não humanos, por sua vez, é que, apesar de serem seres intencionais, não entendem o mundo em termos intencionais. Desse modo, segundo Tomasello (1999), esses indivíduos, em seus habitats, não realizam ações como apontar ou gesticular indicando objetos externos para outros; levar os outros para algum lugar com o objetivo de mostrar a eles algo ali; ensinar intencionalmente novos comportamentos a outros. Além disso, não são capazes de perceber a distinção entre fins (estados intencionais) e meios (métodos comportamentais). A motivação para compartilhar intencionalidade seria exclusivamente humana.

É possível argumentar, baseando-nos em estudos realizados - e citados por Tomasello (2003:50) - com chimpanzés e bonobos criados desde pequenos e por muitos anos em ambiente cultural humano, que esses desenvolvem certos aspectos da cognição e aprendizagem humanas. Entretanto, é necessário ressaltar que há uma grande distinção entre responder a uma cultura ${ }^{72}$ e criar uma - sendo esta última condição impossível para os primatas não humanos.

Assim, para Tomasello, biologia e cultura são complementares, na medida em que tanto aspectos biológicos quanto culturais são determinantes da cognição humana.

\footnotetext{
Os processos sociais e culturais durante a ontogênese não criam as habilidades cognitivas básicas. O que fazem é transformar habilidades cognitivas básicas em habilidades cognitivas extremamente complexas e sofisticadas. (TOMASELLO, 2003:264)
}

Para o autor, a cognição humana é um produto evolutivo derivado de uma base biológica comum a outras espécies, principalmente, a cognição primata, e de um processo de evolução cultural.

Também tratando da questão do salto qualitativo da espécie humana, Paula \& Leme (2010) afirmam ser a vida em comunidade a responsável por fornecer o contexto e as condições necessárias para esse salto. As autoras destacam o conceito de ambiente social e a maior variação e também maior estabilidade que este proveria, favorecendo a previsão de eventos rotineiros, comportamentos, etc. O ambiente social terá sido, de

\footnotetext{
72 Devido à polêmica acerca do conceito de "cultura", é essencial mencionarmos que, na presente dissertação, concebemos este termo como aquele que envolve criação de símbolos e que está mais próximo à noção de "tradição".
} 
fato, de suma importância para a evolução humana, uma vez que apenas através dele torna-se possível a identificação entre os seres e, posteriormente, o reconhecimento como agentes intencionais iguais entre si.

A questão da aquisição de conhecimento pela espécie humana é também tratada pelas autoras, que defendem o conceito de "coevolução entre mente e cultura". Dialeticamente, novas formas de cultura transformariam a mente e transformações cognitivas, por sua vez, dariam origem a novas formas de representação mental e de cultura, assim sucessivamente.

As formas de representação mental, segundo Tomasello, seriam: mente episódica (mais implícita e restrita ao momento e espaço imediatos, o que permitiria aos chimpanzés se orientarem através de uma física intuitiva ou terem senso de numerosidade); mente mimética (referente a um sistema de representação corporal, podendo ser considerada a precursora da capacidade de simular estados mentais alheios); e mente simbólica (surge com a invenção do léxico, da linguagem, permitindo o aumento significativo da variedade de representações do mundo e a percepção de outras perspectivas como forma de dar sentido à realidade, organizar e conservar o conhecimento).

E será justamente essa conservação do conhecimento - possibilitada pela linguagem - que influenciará de modo tão determinante a evolução cultural cumulativa mencionada anteriormente.

A linguagem e outras representações simbólicas são intersubjetivas, por serem socialmente compartilhadas, e perspectivas, uma vez que cada símbolo apreende uma maneira bastante particular de ver alguma entidade ou fenômeno. Desse modo, um objeto pode ser, por exemplo, simultaneamente uma rosa, uma flor e um presente. Ou seja, a espécie humana possui a habilidade de adotar diferentes perspectivas sobre a mesma coisa para propósitos comunicativos diversos e, de modo contrário, de tratar diferentes objetos ou entidades como se fossem os mesmos, também para algum propósito comunicativo. Assim como, na língua, uma mesma forma pode desempenhar diferentes funções, diferentes formas podem desempenhar a mesma função. E a apreensão de determinada função por determinada forma denuncia uma perspectiva assumida pelos usuários da língua. A gramaticalização - processo através do qual uma forma passa a desempenhar outra função - denuncia, assim, o modo como o pensamento humano se processa. 
Os símbolos linguísticos são, então, convenções sociais criadas para induzir os sujeitos a interpretar uma situação experiencial de um determinado modo e não de outro ou assumir uma perspectiva em relação a ela. Segundo Tomasello, esses símbolos:

\begin{abstract}
(...) incorporam uma miríade de maneiras de interpretar intersubjetivamente o mundo que se acumularam numa cultura ao longo do tempo histórico, e o processo de aquisição do uso convencional desses artefatos simbólicos e, portanto sua internalização, transformam fundamentalmente a natureza das representações cognitivas da criança. (TOMASELLO, 2003: 133)
\end{abstract}

Algumas das transformações provocadas em um indivíduo após a aquisição de símbolos linguísticos serão tratadas posteriormente nesta dissertação. Por ora, será abordada a aquisição desses símbolos. Para que ela ocorra, é necessário ao sujeito viver em um mundo que tenha interações sociais e atividades sociais estruturadas as quais ele possa entender. Para as crianças, isso muitas vezes implica a recorrência da mesma atividade de forma regular ou rotineira, para que seja possível a ela discernir como esta funciona ${ }^{73}$. Em um mundo onde um mesmo evento ou fenômeno nunca ocorre de forma repetida, ou um mesmo objeto nunca aparece mais de uma vez, ou ainda os adultos nunca usam a mesma linguagem em um mesmo contexto, seria difícil imaginar de que maneira uma criança seria capaz de adquirir uma língua natural. Tomasello (2003:4) afirma que crianças pré-linguísticas (abaixo de um ano de idade) buscam padrões repetidos no que ouvem para construir unidades linguísticas ${ }^{74}$. Para o autor, habilidades como (i) identificar e reconhecer combinações recorrentes de elementos em uma sequência - de modo a identificar e reconhecer sequências; (ii) criar analogias entre duas ou mais totalidades, incluindo expressões linguísticas, o que pressupõe reconhecer similaridades entre elementos presentes nessas totalidades; entre outras, são exercícios necessários para que as crianças identifiquem padrões no modo como os adultos empregam os símbolos linguísticos em contextos diversos. É a partir daí que será possível a elas construir as dimensões gramaticais - que são abstratas - da competência linguística humana.

Realizando estudos com crianças pré-linguísticas, Marcus et alii (1999:77) descobriram que crianças de sete meses de idade, quando expostas, por três minutos, a

\footnotetext{
${ }^{73}$ Essa repetição de formas, gerando habituação, é essencial também para que seja possível aos adultos empregá-las em outras funções, promovendo os chamados deslizamentos funcionais.

${ }^{74}$ Ideia essa que dialoga com os conceitos de construções, uma vez que são essas as adquiridas pelas crianças, e não palavras isoladas, e de gramaticalização, já que a repetição de construções leva à formação de padrões, os quais, uma vez identificados, possibilitarão o processo de aquisição descrito.
} 
sequências de palavras trissilábicas sem sentido seguindo o padrão $\mathrm{ABB}$ (ex. venini, bulala), acabavam, em testes posteriores, dirigindo seu olhar para cadeias sonoras que continham outras palavras sem sentido que apresentavam o mesmo padrão $A B B$, embora as sílabas envolvidas fossem outras (ex. bароро). Esses e outros experimentos forneceram evidências de que crianças pré-linguísticas são capazes de reconhecer padrões silábicos de palavras em uma cadeia sonora. Ou seja, temos a comprovação de que crianças, nesse estágio bastante inicial de contato com a língua, antes de adquirirem as primeiras palavras, já possuem a habilidade de identificar padrões. Essas foram também as conclusões de Spelke et alii (1992) em seus experimentos com bebês de dois meses e meio, os quais revelaram as diversas capacidades já possuídas, dentre elas a de reconhecer e mostrar claro apreço por pessoas que usam padrões de discurso a que eles já foram expostos, por exemplo: um bebê norte-americano olha durante mais tempo para alguém que fala inglês do que para alguém que fale francês. Também Saffran et alii $(1996,1999,2003)$ verificaram em seus experimentos que tanto adultos quanto crianças identificam a co-ocorrência de padrões e regularidades em gramáticas artificialmente criadas, o que indica que padrões são aprendidos mesmo quando as asserções em questão não correspondem a nenhum significado. Fica claro, portanto, o impacto da co-ocorrência de palavras, ou seja, de construções linguísticas, na representação cognitiva e, para nos mantermos no campo dos sistemas linguísticos, enfim, na codificação sintática.

\subsubsection{A aquisição de símbolos: o desenvolvimento de habilidades cognitivas e outras consequências}

Além do desenvolvimento de habilidades cognitivas, a aquisição de símbolos acarreta outros fatores. Sabe-se, por exemplo, que ao longo do percurso histórico, os artefatos simbólicos constituintes de qualquer língua acumulam modificações, conforme novas formas linguísticas são criadas ou modificadas através de processos de gramaticalização e outras mudanças linguísticas. Desse modo, ao adquirir um símbolo linguístico, o sujeito está aprendendo a maneira como aqueles que o precederam na cultura consideraram útil manipular e concentrar a atenção dos outros em seu tempo, além do modo como conceituavam o mundo, e passa, então, a conceituá-lo da mesma maneira. Todo artefato linguístico tem em si incorporadas diferentes perspectivas 
humanas e estas são adquiridas pelo sujeito aprendiz. É justamente esse aspecto dos símbolos linguísticos que o separam do mundo sensório-motor dos objetos no espaço e os situa no âmbito da capacidade humana de ver o mundo da maneira que for mais apropriada para o propósito comunicativo em questão.

Neste ponto, coloca-se como conceito interessante o de "construção linguística", já abordado sob outro enfoque na presente dissertação. Ao mesmo tempo em que adquire palavras, a criança adquire construções linguísticas mais amplas. De fato, crianças dificilmente entram em contato com palavras isoladas, fora de algum contexto, e muitas das palavras foram na verdade, num momento de gerações anteriores, construções sintáticas maiores. Mesmo que a aprendizagem de palavras possa, em outra perspectiva, ser conceituada como isolamento e extração de construções linguísticas mais simples da língua, também aí estariam incorporadas a construções mais amplas e complexas $^{75}$. Assim, quando uma criança fala, por exemplo, a palavra "boneca", há todo um contexto envolvido neste ato de fala. Ela pode estar pedindo para que alguém pegue aquele objeto para ela, ou simplesmente tem a intenção de direcionar a atenção do outro para o objeto em questão.

Além disso, uma construção pode transformar-se, em algum momento do desenvolvimento, em um símbolo por si só, carregando um sentido de certo modo independente das palavras envolvidas em sua constituição. Logo, uma criança pode adquirir o sentido de uma construção inteira como se esta fosse um bloco, sem necessariamente compreender totalmente o sentido de cada palavra constituinte desta construção. Inversamente, pode empregar uma holófrase codificada em um só item.

O caráter bastante abstrato de algumas construções linguísticas faz com que estas sejam adquiridas com mais dificuldade e mais tardiamente pelas crianças. $\mathrm{O}$ contato com construções como "perder a paciência", "tirar isso da cabeça", "entrar (ou sair) na (da) linha" levam o sujeito a desenvolver seus domínios mais abstratos. Tomasello afirma que:

As crianças deparam com esse aspecto do inventário linguístico de sua cultura, têm de lidar com ele e finalmente usá-lo. A flexibilidade de pensamento que

${ }^{75} \mathrm{O}$ fato de adquirirmos palavras a partir de seus usos e não a partir de seus isolamentos (fora de contexto, fora de construções) referenda a ideia de que a aprendizagem contextualizada da língua, a partir do uso, ou seja, aquela guiada pelo funcionalismo, seria muito mais natural para nós do que aquela que prevê a descrição de regras anteriormente à análise das funções desempenhadas pelos elementos linguísticos. 
disso resulta é, em suma, impensável numa espécie animal cujos membros não se comunicam simbolicamente entre si e portanto não armazenam um repertório de interpretações simbólicas abstratas. (TOMASELLO, 2003: 236)

O contato com abstratizações irá, então, também proporcionar o surgimento de novas habilidades cognitivas. As crianças terão disponíveis para si novas aptidões. Porém, vale ressaltar que a linguagem não cria, por ela mesma, a capacidade de fazer analogias, metáforas e outras abstratizações. Isso não seria possível, já que a própria linguagem depende dessa capacidade, ainda que em um formato básico, para se instituir da existência. O que ocorre é que, conforme as crianças se desenvolvem, utilizam suas aptidões básicas de categorização, perspectivação e sua capacidade de perceber e compreender as intenções comunicativas dos outros para adquirir o aprendizado do uso de formas simbólicas. A aquisição de símbolos ocorre, desse modo, via reconhecimento de intenções que estão presentes no emprego desses símbolos ${ }^{76}$. A criança torna-se capaz de interagir com outros membros de sua cultura através de construções tanto concretas quanto abstratas, uma vez que já teria assimilado seus usos através de repetidas interações sociais que vivenciou.

No entanto, apesar de já possuírem as aptidões básicas citadas, será apenas através da aquisição da linguagem que a criança será capaz de conceituar, categorizar e esquematizar eventos de maneiras bem mais complexas do que o faria se não aprendesse nenhuma língua e se mantivesse, desse modo, apenas com as habilidades cognitivas básicas. Sabe-se que outros animais podem também ser capazes de exibir determinada flexibilidade comportamental, entretanto não compreendem o fato de haver infinitas possibilidades pelas quais um evento possa ser interpretado. A explicação para este fenômeno consistiria no fato de esses animais não terem a seu dispor as diversas perspectivas dos outros indivíduos incorporadas na linguagem, além de não serem capazes de reconhecê-los como agentes dotados de intencionalidade.

Já para os humanos, haveria uma progressão desenvolvimental contínua, durante a primeira infância, na compreensão que possuem dos outros. De modo bastante resumido, estes seriam os estágios apresentados por Tomasello (2003:250): reconhecimento do outro como agente animado (capacidade possuída em comum com todos os primatas); como agente intencional (habilidade específica da espécie humana,

\footnotetext{
${ }^{76} \mathrm{O}$ reconhecimento de intenções por trás do emprego de construções será primordial, como veremos, para o processamento da gramaticalização.
} 
que inclui dois elementos: a compreensão de comportamentos como sendo dotados de objetivos e o entendimento da atenção do outro); e como agente mental (habilidade de compreender o outro como um ser que não possui apenas intenções e atenção, manifestas em seu comportamento, mas também pensamentos e crenças, que podem ou não estar expressos em seu comportamento). Resta, contudo, ainda um dado relevante: é que a intenção não é somente subjetiva; ela é também intersubjetiva. Ela age na mente de quem diz, porém seus efeitos transcendem a outro espaço mental: o da alteridade.

\subsubsection{A intencionalidade compartilhada}

Tomasello (1999) define a cognição humana como constituída a partir do compartilhamento de experiências com os outros e com os mundos sensório-motor e social. Esses possibilitam a formulação de estratégias para agir no mundo físico e social.

Estudando o papel desempenhado pela língua na comunicação humana, Tomasello refuta a ideia apresentada por estudiosos a respeito do exemplo da criança selvagem na ilha deserta. A questão seria a seguinte: em quanto tempo as crianças criariam algo diferente, mas equivalente às práticas sociais e institucionais, tais como língua, matemática, escrita, governo e outros? Para muitos estudiosos, a resposta para a questão seria: imediatamente. Tomasello discorda. Para ele, a linguagem só pode ser criada em determinados tipos de interação social, e alguns tipos de construção só podem ser criados após outros já o terem sido ${ }^{77}$. O que isso quer dizer? Que a interação social é a mola propulsora da evolução da língua. É ela que leva a língua a evoluir num contínuo, a reconstruir-se ao longo do tempo. A razão não é outra se não o fato de que, quando interagimos, contamos com a colaboração do outro e também com as informações compartilhadas para a intercompreensão. Mesmo na modalidade escrita, um jogo contínuo de trocas permanece em curso. Segundo Paul (1966:18), "só a sociedade possibilita a cultura, só a sociedade torna o homem um ser histórico". De acordo com ele, é apenas através da transmissão a outros indivíduos daquilo que um indivíduo aprendeu e da colaboração de vários indivíduos para um mesmo fim que se torna possível o desenvolvimento cultural. Para se entender melhor o peso assumido

\footnotetext{
${ }^{77}$ Ilustra essa posição casos como o de Genie, uma menina que ficou apartada da sociedade por dez anos. O documentário "Wild Child" exibe, num registro feito por uma equipe multidisciplinar de pesquisadores, a adaptação social da menina. (Fonte de divulgação: http://www. youtube.com/watch?v=hmdycJQi4QA).
} 
pela interação social, torna-se interessante a apresentação de alguns conceitos desenvolvidos por Tomasello (2008) a respeito da comunicação humana.

Na evolução filogenética, a motivação humana para ajuda e compartilhamento menos importante, ainda que presente, nos primatas não-humanos - pode ter surgido como uma forma de adaptação para melhorar suas atividades colaborativas. Ao conceder pedidos, podia estar colaborando para um bem mútuo; ao oferecer ajuda, podia estar melhorando sua reputação perante seu grupo e garantindo que, quando precisasse, também obteria ajuda; e ao compartilhar emoções, estaria se reafirmando como membro de um grupo.

Nessas atividades colaborativas, os indivíduos envolvidos possuiriam um objetivo comum, compartilhado por todos os outros, havendo, assim, uma coordenação entre eles. Nesse sentido, cada um desenvolveria um papel que estaria inter-relacionado com os dos outros participantes. Isso possibilitaria o que Tomasello (2008) denomina de "intencionalidade compartilhada". E uma habilidade sociocognitiva primordial para isso seria o recursive mind reading, em outras palavras, uma memória recursiva, o que favoreceria um common ground ${ }^{78}$ entre os participantes. A tensão entre o que se sabe ou se imagina saber que o outro saiba é que seria a base desse conhecimento compartilhado $^{79}$. E é só deste modo que se torna possível coordenar uma ação conjunta: cada indivíduo possuindo um objetivo comum com os outros e podendo fazer suposições acerca do que esses estão esperando.

O interessante é que isso não é só típico do ser humano. Os grandes primatas não humanos demonstraram entender ações intencionais de outros seres e trabalhar em grupo. Ainda segundo Tomasello, algo parece diferente: eles não possuem competências ou motivações para compartilhar intencionalidade, ou seja, buscam atingir um objetivo de maneira egoísta, inclusive nas atividades em grupo, como a caça nos chimpanzés, por exemplo, em que a intenção de cada envolvido é conseguir para si mesmo a presa buscada. Os humanos, por sua vez, conseguem compartilhar intencionalidade, reconhecendo o outro como um ser com intenção, atenção, opinião e desejos próprios, tais como ele mesmo.

\footnotetext{
${ }^{78}$ Na definição de Tomasello, common ground é constituído por conhecimentos, crenças e suposições compartilhados pelos participantes da comunicação.

${ }^{79} \mathrm{O}$ common ground é essencial para que inovações na língua sejam compreendidas pelos usuários, ou seja, obtenham sucesso comunicativo ao serem empregadas, e possam tornar-se convencionalizadas.
} 
É essa diferença que faz com que o ser humano tenha de "vencer" alguns obstáculos para conseguir comunicar-se eficientemente, em qualquer contexto de interação social. Terá de codificar suas intenções de tal modo que possam ser decodificadas adequadamente pelo seu interlocutor, sempre se lembrando de que este é um indivíduo também dotado de intenções e opiniões próprias, as quais constituirão o viés a partir do qual as intenções do emissor serão decodificadas. Mas Tomasello não está sozinho nessa posição teórica. De acordo com Givón (2005), o falante, além de construir mentalmente a realidade física externa - como já foi tratado nesta dissertação - constrói também, para si, o que ele assume que sejam os estados mentais de conhecimento, crença e intenção de seus interlocutores.

Em suma, o evento de uso da língua é, então, uma instância de interação real, em que o falante/escritor deve selecionar as construções linguísticas que evoquem um entendimento desejável do contexto, e o ouvinte/leitor deve interpretar o evento como intencionado pelo falante. A cada situação nova com a qual o usuário da língua se depare, pode ser que uma reanálise tenha de ser efetuada e que uma construção seja recontextualizada, assumindo novas funções - para que a comunicação se efetue de modo eficiente. Novas situações surgem constantemente, uma vez que o mundo muda, a mente muda, as perspectivas mudam. A necessidade de expressar novos conceitos, novas perspectivas, surge a todo momento. A inovação linguística é, portanto, uma necessidade. É a solução para problemas comunicativos. A mudança linguística é, nesse sentido, associada ao processo evolutivo das espécies, o qual, como postulou Dalgalarrondo (2011), “é, em certo sentido, conservador, ele não 'joga fora' as estruturas antigas para recomeçar do zero, mas descobre formas de reciclá-las e remendá-las para novos usos que os desafios ambientais passam a exigir." No caso das construções linguísticas, os “desafios ambientais" seriam aqueles oferecidos pelas situações comunicativas, as quais levariam à exploração de velhas formas para novas funções.

A questão da intencionalidade é também tratada por Searle (2007), sob outro viés. O autor propõe a necessidade de se distinguir entre significado linguístico, significado de sentenças e atos discursivos como uma extensão da maioria das formas biologicamente fundamentais de intencionalidade, percepção e ação intencional.

De acordo com Searle, percepções, crenças, desejos, entre outros, são formas de intencionalidade, e estariam presentes até mesmo em animais irracionais. Todas teriam 
origem em um contexto pré-linguístico. O cachorro de Searle, como ele menciona, por exemplo, é capaz de perceber quando um desejo seu não foi atendido, assumindo, assim, uma postura de insatisfação.

Esse é o mote para que o autor coloque em pauta a seguinte questão: o que falta na consciência pré-linguística? O que torna a consciência linguística diferenciada? Segundo Searle, formas pré-linguísticas de intencionalidade possuem estrutura, mas não tipos de estruturas indefinidamente manipuladas com conteúdo semântico que a sintaxe da língua fornece. A estrutura de memória de um animal qualquer seria formada pelo puro evento físico e pelos aparatos fisiológicos, mas sem elementos sintáticos. A sentença, por sua vez, é designada para codificar o conteúdo proposicional de um estado intencional. Chega-se, portanto, a um interessante conceito: a codificação sintática de intenções, tal como postulado na construção do objeto desta pesquisa: a análise das intenções que estariam sintaticamente codificadas por meio da construção quase que.

A partir dos conceitos desenvolvidos, é possível notar que, além da cognição, a intenção assume um grande peso para o estudo de gramaticalização. Ampara essa ideia o fato de que os processos cognitivos e os estados intencionais de quem usa a língua em suas virtualidades definem os rumos que cada palavra ou construção, assim como a funcionalidade destas, vai tomar, na tentativa exercida por cada falante de se comunicar de forma eficiente. Então, se o candidato ao vestibular redige o seguinte: No Brasil, o que temos é uma QUASE QUE completa negação da autoestima (...), não é difícil compreender que há uma intenção no uso da construção quase que precedendo essa escrita. A forma sintática dá corpo linguístico ao que, antes, era ideia, era intenção (um momento pré-verbal).

\section{A Linguística Baseada no Uso}

Uma vez que os seres humanos não nascem com um conjunto específico de comportamentos relacionados à comunicação, as crianças têm de aprender, ao longo de suas ontogêneses, o conjunto de convenções linguísticas usadas por aqueles que estão a sua volta. Em qualquer língua, esse conjunto corresponde a talvez centenas de milhares de palavras, expressões e construções. Segundo Gombert (2003), a linguagem, ainda que seja apenas em sua modalidade oral, "encontra-se em parte sob a dependência de 
pré-programações inatas, de processos biologicamente determinados, que são automaticamente ativados quando o bebê entra em contato com a linguagem de seu ambiente." Apesar de estarem, dessa forma, biologicamente preparados para a árdua tarefa de adquirir tantas construções, essa "preparação" inata não pode ser específica demais. As mentes das crianças precisam ser flexíveis o suficiente para que lhes seja possível adquirir não somente as diferentes palavras e expressões convencionais de qualquer língua, mas, principalmente, os chamados padrões abstratos de construção que cada língua gramaticalizou ao longo de sua história. Como seria possível tal aquisição?

Skinner (1957), representante dos analistas do comportamento, propôs que crianças aprendem "pedaços" de linguagem por meio de condicionamento instrumental - baseado em princípios de associação - e que generalizam o que aprendem a novas instâncias, guiadas por princípios de indução. Chomsky, criticando esse modelo, argumentou que há certos princípios da gramática que são tão abstratos e, de certo modo, arbitrários, que seria impossível para a criança aprendê-los por meio de processos de associação e indução. O autor propõe, então, seu conceito de Gramática Universal e defende a hipótese do inatismo, de acordo com o qual teríamos todos já nascido com uma gramática universal (GU), contendo um número de princípios abstratos que guiariam o processo de aquisição. Isso favoreceria que a GU fosse desenvolvida em concordância com o ambiente em que vivamos.

Negando esses modelos, estudiosos da Linguística, da Psicologia do Desenvolvimento e das Ciências Cognitivas propõem, na década de 1980, uma nova abordagem: a aquisição da linguagem não seria autônoma, mas, sim, integrada com outras habilidades cognitivas e sociais. O novo aparato teórico defende que (i) as crianças detêm mecanismos de aprendizagem muito complexos e poderosos e (ii) possuem uma competência bastante próxima a do adulto, diferentemente do que era postulado pelo modelo gerativista, estando a meta da aquisição não tão distante de seus estágios iniciais, como se acreditava anteriormente.

Chamados de Modelos Baseados no Uso, ou usage-based linguistics, os novos modelos teóricos postulam que a dimensão gramatical da linguagem é produto de um conjunto de processos históricos e ontogenéticos, denominados, em sua coletividade, sob o rótulo de "gramaticalização". Quando seres humanos se comunicam, empregam símbolos, arranjando-os juntos, em sequências. Surgem, desse modo, padrões de uso que, com o tempo, se consolidam em construções gramaticais. A nova abordagem 
concebe construções linguísticas como elas próprias símbolos linguísticos significativos, já que não passam, na verdade, de padrões de acordo com os quais símbolos linguísticos significativos são empregados na comunicação. E refletir a respeito dessa definição nos leva a concluir que, como afirmou Wittgenstein (2003[1953]:6), “children can use function or meaning to assist in their acquisition, just as they do in their acquisition of smaller linguistic constructions such as individual

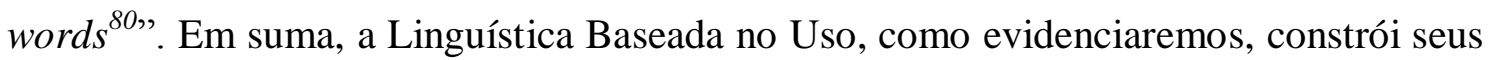
pilares teóricos na ideia de que a organização cognitiva da língua é baseada diretamente na experiência com a mesma.

Essa experiência envolve momentos de interpretação contínua. Por isso, o ato interpretativo é sempre peça fundamental para o propósito da comunicação em cada ocasião de uso da língua. É por este motivo que Croft é categórico ao afirmar que

in order to understand the nature of construal, we must consider construal in the light of the use of language for communication in joint actions, the nature of the communities to which the interlocutors belong, and the nature of common ground and the evidence each of us has for it ${ }^{81}$. (CROFT, 2009:413)

Para a análise linguística, coloca-se como mais importante o estudo do ato interpretativo "em ação", ou seja, atuando no momento em que a língua é usada para a comunicação do que a abordagem a respeito de sua natureza, suas definições. A Linguística Centrada no Uso ${ }^{82}$ prevê o trabalho essencialmente com dados reais de fala e/ou escrita, extraídos de contextos efetivos de interação verbal (e preservando-os como apoio de análise). Assim, o contexto, como argumentado por Lima- Hernandes (2013), é fundamental para se reconhecer a intencionalidade do falante/escritor e as condições de receptor do ouvinte/leitor. Observar a língua em uso é a melhor maneira de, enquanto estudiosos, desenvolvermos nossa capacidade de compreender o trabalho silencioso dos falantes/escritores durante o processo comunicativo: adequar os usos às intenções comunicativas. Lidar com o contexto de produção, em última análise, é reconhecer que os falantes/escritores estão continuamente, em meio às situações comunicativas,

\footnotetext{
${ }^{80}$ Crianças conseguem usar função ou significado para dar apoio em sua aquisição, assim como elas fazem em sua aquisição de construções linguísticas menores, como palavras individuais. (tradução sugerida)

${ }^{81}$ Para entender a natureza da interpretação, nós devemos considerar a interpretação à luz do uso da língua para comunicação em ações conjuntas, da natureza das comunidades às quais os interlocutores pertencem, e da natureza do common ground e da evidência que cada um de nós tem dele. (tradução sugerida)

${ }^{82}$ Outra nomenclatura dedicada à Linguística Cognitivo-Funcional.
} 
categorizando fatos, coisas, seres e, acima de tudo, as próprias construções linguísticas em uso.

\section{A categorização e os conceitos de objetividade e (inter)subjetividade}

Essencial para a linguagem, a categorização é o processo através do qual agrupamos entidades semelhantes (objetos, pessoas, lugares, etc.) em classes específicas. Para ilustrá-lo, podemos pensar em um guarda-roupa e nos seus diferentes compartimentos, os quais utilizamos como forma de separar os tipos de peças do vestuário de acordo com os critérios que desejarmos. E, assim, teremos categorizado os diferentes tipos de roupa. Do mesmo modo, para falarmos do mundo, agrupamos os objetos, as pessoas, as atividades, as qualidades em classes específicas, de acordo com características por nós julgadas como similares. Similarmente, as categorias são classificadas para organizar a língua e a forma de categorizar deixa ver em que medida objetos da natureza e da cultura são experienciados no mundo, ou seja, as categorias linguísticas são baseadas na experiência que temos com as construções em que elas ocorrem. A categorização conceptual e a categorização linguística são, portanto, análogas, seguem, em sua essência, os mesmos padrões.

Não é a forma dos objetos e construções linguísticas que causa a percepção de uma unidade: nossa mente e nosso corpo atribuem-lhes esse status, da mesma forma que o sentido de um quadro não está no quadro em si, mas na interpretação que a partir dele fazemos. Se, de um lado, dividimos o mundo, criando categorias para que possamos manipulá-las em nossas vidas humanas, de outro, ao categorizar estamos oferecendo pistas da evolução de nossa espécie. Em outras palavras, esse modo de agir é resultado do que ocorreu na filogenia - bilhões de anos de evolução - e na ontogenia alguns meses de treinamento na infância.

A categorização é uma estratégia intrinsecamente relacionada à capacidade humana de memória ${ }^{83}$. A necessidade de agruparmos tudo em categorias vem da incapacidade de lidarmos com um número infinito de entidades, o que acarretaria sobrecarga em termos de processamento e armazenamento de informações. A relação

\footnotetext{
${ }^{83}$ É por esse motivo que, na língua, um conjunto de unidades e construções atende a um conjunto bem maior de funções, e não vice-versa.
} 
entre linguagem e mundo é, pois, mediada pelas habilidades e restrições da cognição dos falantes.

Vários são os modelos de categorização, os quais visam determinar como serão eleitos os atributos relevantes para a inclusão de um elemento em determinada categoria. O modelo de categorização proposto por Aristóteles estabelece que, para pertencer a determinada categoria, o elemento deva apresentar todos os atributos definidores da mesma. Já Katz e Fodor (1963) propõem um sistema de traços para definir a estrutura semântica dos itens lexicais. Assim, a entidade "cavalo", por exemplo, seria assim categorizada: [equino], [+macho], [+adulto], enquanto "égua" seria [equino], [- macho], [+adulto] e "potro", [equino], [+macho], [- adulto]. Esse modelo sustenta um limite rígido entre as categorias, as quais são tratadas de modo objetivista, como reflexos diretos do mundo. Surge a necessidade de se pensarem categorias em outros termos, como classes formadas por elementos que mantêm alguns traços em comum e não necessariamente todos os traços. A reflexão de Labov (1973) nos conduzirá a concluir que, além de as categorias não representarem divisões arbitrárias de entidades do mundo, mas, sim, terem surgido baseadas em capacidades cognitivas da mente humana - sendo denominadas, então, categorias cognitivas - há, entre elas, fronteiras imprecisas, de modo que categorias vizinhas não são separadas por limites rígidos, mas por zonas de intersecção. Há, em consequência, membros intermediários entre protótipos e fronteiras categoriais. A organização categorial envolve desde representantes mais centrais, com uma suficiente similaridade ao protótipo, até representantes mais periféricos, os quais apresentam poucos traços em comum com o núcleo categorial. É o que observamos, por exemplo, ao compararmos os elementos "sabiá", "avestruz" e "pinguim". Pensando-se em traços definidores da categoria "ave", notamos que, dentre os animais selecionados, o "sabiá" é o que corresponde ao núcleo prototípico dessa categoria, por possuir todos os seus traços definidores: tem bico, dois pés, duas asas, penas, põe ovos e pode voar. O "avestruz" apresenta quase todos os traços - apenas não sabe voar. Enquanto o "pinguim", apenas três traços - tem bico, dois pés e põe ovos - o que o coloca mais próximo da fronteira categorial.

As categorias cognitivas armazenadas na memória permanente têm, portanto, papel decisivo na construção do significado. Juntamente aos espaços mentais, conceito 
que abordaremos a seguir, elas nos permitem concluir que a interpretação envolve sempre mais informação do que aquela diretamente codificada na forma linguística ${ }^{84}$.

Os espaços mentais (mental spaces) são "quadros" de lembranças acessíveis, criados a partir da experiência que os seres sociais envolvidos na enunciação têm do mundo e de suas próprias experiências, e que permitem o sucesso da comunicação, uma vez que intenções só são efetivamente transmitidas nos contextos em que os envolvidos: (i) dedicam-se a colaborar com seus coespecíficos, estabelecendo com eles uma atenção conjunta a respeito do contexto do ato de fala; (ii) compartilham conhecimentos prévios que permitem ao falante antecipar a interpretação do discurso pelo ouvinte, o que o guiará em suas escolhas para construir seu enunciado e transmitir suas intenções da maneira mais clara possível; (iii) são capazes de associar, dentro do discurso, através dos espaços mentais, elementos previamente ditos ou já conhecidos com informações novas. Salomão (2005:155) será a favor dessa posição, definindo os espaços mentais como:

\begin{abstract}
internamente especificados por herança, seja de bases de conhecimento estabilizado (modelos culturais, scripts, esquemas conceituais), seja de outros espaços mentais previamente originados. Sendo assim, sua especificação é sempre parcial, atendendo exclusivamente às necessidades comunicativas de enquadramento ou de especificação. Tais condições fazem da teoria dos espaços mentais um instrumento poderoso para explicar a dinâmica da interpretação em tempo real.
\end{abstract}

A parcialidade da especificação dos espaços mentais está intimamente relacionada à questão da objetividade e da subjetividade, uma vez que esses conceitos intermedeiam as descrições e as representações dos pontos de vista dos falantes. Em linhas gerais, a subjetividade diz respeito à representação, no discurso, da visão pessoal e subjetiva desenvolvida por um sujeito da consciência, enquanto a objetividade, como defende Maturana (2001), deveria ser apresentada de suas formas: objetividade sem parênteses e objetividade entre parênteses. A primeira faria referência a algo independente de nós, algo que é da maneira que é, e sob o qual não temos responsabilidade, ou seja, algo ao qual, ao nos referirmos, estaríamos aludindo ao seu conceito universal para o mundo e não ao seu significado específico para nós. Já ao considerar a objetividade entre parênteses, estaríamos assumindo que não é possível

\footnotetext{
${ }^{84}$ É o que observaremos no emprego da construção quase, cuja análise revela diferentes funcionalidades, apontando para a existência de sentidos que vão além dos diretamente codificados.
} 
fazer referência a algo independentemente de nós, pois somos responsáveis pelos conceitos que construímos. Essa é a realidade objetiva de cada um. A pressuposição da neutralidade é, por conseguinte, uma idealização. Ao nos comunicarmos, não podemos nos desfazer de nosso "eu" observador e crítico, nem podemos tomar como referência algo independente de nós, pois tudo já está “maculado" por nosso ponto de vista. A não objetividade da linguagem fica bastante evidente quando analisamos os empregos da construção quase em termos de "objetividade", subjetividade e intersubjetividade, como observaremos posteriormente.

A subjetividade tem diversos usos e interpretações, alguns, inclusive, de conotação negativa. Ao ser empregado como termo não técnico na linguagem cotidiana, refere-se à situação de deixar-se influenciar por um opinião pessoal, muitas vezes, injustamente, como em: "seus julgamentos são muito subjetivos". Em investigações científicas, o termo é usado para sugerir algo não baseado em fato empírico, algo não verificável. Em Linguística, o termo refere-se, grosso modo, à centralidade do falante na língua.

Por boa parte do século XX, a subjetividade não era um tópico de pesquisa de grande preocupação. Foi apenas nas últimas duas ou três décadas que se notou um interesse pelo tema, principalmente, no âmbito da tradição cognitiva-funcional. De particular importância foi a introdução do termo "sujet d'énonciation" (sujeito da enunciação) por Benveniste (1966) (em contraste ao termo “sujet d'énoncé”, sujeito do enunciado, ou seja, sujeito sintático). Segundo o autor $(1966: 261)^{85}$, a língua é tão fortemente marcada pela subjetividade que se pode até questionar se ela ainda funcionaria do mesmo modo ou se poderia ainda ser chamada de língua se fosse organizada de modo diferente. Posteriormente, maior atenção passou a ser direcionada ao conceito de subjetividade, como observaremos, mais adiante, pela apresentação de diversos autores que dele trataram. Derivada da subjetividade, a intersubjetividade é, também segundo Benveniste (1974), inerente à língua, uma vez que reflete o impacto da situação comunicativa, a qual envolve não só um falante, mas também uma relação comunicativa entre falante e ouvinte. $\mathrm{O}$ autor ressaltou essa díade falante-ouvinte, e, particularmente, a consciência e o reconhecimento, por parte do sujeito falante, do outro participante também como sujeito falante, como condição fundamental para a

\footnotetext{
${ }^{85}$ No original: "Le langage est marqué si profondément par l'expression de la subjectivité qu'on se demande si, autrement construit, il pourrait fonctionner et s'appeler langage".
} 
comunicação linguística. Mais recentemente, Traugott (2003:128), enfatizou que a intersubjetividade é uma característica geral de todo uso linguístico: "Of course, in a general sense the very fact of communicating with another person entails general intersubjectivity ${ }^{86}$."

Como já afirmamos, as escolhas denunciam intenções. Partimos daí para focarmos na identificação de possíveis elementos linguísticos, atrelados à construção quase, nos quais haveria a codificação de significados intersubjetivos. Então, entender em que esfera eles podem ser apreendidos é missão deste capítulo.

Por Lyons (1982), a subjetividade é descrita como o modo como a linguagem natural, em sua estrutura e em sua forma normal de operação, fornece para o agente locucionário expressões de si mesmo e de suas próprias atitudes e crenças, e, por Traugott (2003), como referente à tendência para o aumento da pragmatização de significados enfatizando a externalização do ponto de vista do falante.

Inicialmente descrito pela filosofia, o termo intersubjetividade passou a ser utilizado por outras áreas de conhecimento, como a Psicologia, a Comunicação e a Linguística. Buscando uma melhor compreensão a respeito de seu significado, recorremos à seguinte definição de Houaiss \& Villar:

Comunicação de consciências individuais, umas com as outras, realizada com base na reciprocidade. Nota: em diversas linhas do pensamento contemporâneo, a intersubjetividade indica o campo de interação comunicativa ou relação interpessoal que, em oposição aos subjetivismos individualistas, constitui o sentido pleno da experiência humana. (HOUAISS \& VILLAR, 2009:1637)

Baseada na reciprocidade entre indivíduos, a intersubjetividade é o que torna possível a interação comunicativa. Intersubjetividade relaciona-se à inferência, por parte do falante/escritor, da percepção ou compreensão que o ouvinte/leitor fará de sua mensagem, a partir de "pistas" socialmente estabelecidas e que, como evidenciaremosos, poderão estar sintaticamente codificadas.

Desenvolver a intersubjetividade requer habilidades linguísticas descritas como essencialmente humanas, já que se acredita que apenas os seres humanos sejam adaptados biologicamente para participar de atividades compartilhadas socialmente

\footnotetext{
${ }^{86}$ Naturalmente, em um sentido geral, o simples fato de se comunicar com outra pessoa implica intersubjetividade geral. (tradução sugerida)
} 
(TOMASELLO, 2003). Além de se compreenderem as intenções e percepções do outro, conceito já explanado no presente capítulo, é necessário haver motivação para compartilhá-las.

Ao entender as intenções e percepções do outro, o indivíduo desenvolve a cognição cultural, a partir da aprendizagem cultural. $\mathrm{O}$ aprendizado das expressões linguísticas por crianças será reflexo da intersubjetividade e se dará com a ajuda do contexto linguístico no qual estão inseridas.

Isso nos motiva a rever esses conceitos comparativamente ao que linguistas que dialogam mais de perto com o que temos realizado em gramaticalização têm se dedicado. Assim, repassaremos, a partir deste ponto, as propostas a respeito de objetividade, subjetividade e intersubjetividade defendidas por Traugott e Dasher (2005), Langacker (1987, 1990, 2008), Verhagen (2005) e Nuyts (2001). Após a apresentação dos conceitos, definiremos como as propostas serão aplicadas à análise.

\section{Traugott e Dasher}

O conceito de objetividade, para esses autores, baseia-se na ausência de elementos discursivos, como os dêiticos, as inferências, a modalidade. Em contextos de objetividade, os enunciados são predominantemente declarativos, quase não demandam inferência e não sinalizam a perspectiva dos interlocutores.

Traugott e Dasher (2005) defendem a ideia de que a experiência é determinada pela linguagem e por outros mecanismos de percepção, o que conduziria a que os conceitos de objetividade e de subjetividade no uso da língua estejam relacionados ao conceito de perspectiva linguística. A codificação de subjetividade, segundo os autores, dá-se através do uso da dêixis, da modalidade e de marcadores discursivos. Assim, sinalizam atitudes ou pontos de vista do falante, enquanto a intersubjetividade sinaliza a atenção (ou o monitoramento) do falante em relação a seu interlocutor. O falante/escritor sinaliza, em sua expressão linguística, a inclusão do ouvinte/leitor como participante do evento comunicativo, aliás muito do que diz é já a manifestação de suas intuições guiadas pelos sinais emitidos pelo interlocutor. Para esses autores, sem subjetividade, não há intersubjetividade: “a subjetividade é um pré-requisito para a intersubjetividade na medida em que a atitude do falante/escritor com relação ao ouvinte/leitor é uma função da perspectiva do falante/escritor” (2005:22). A 
intersubjetividade, por sua vez, tem suma importância, segundo Traugott (2003), uma vez que é através dela que o falante/escritor se constitui como sujeito: "Speakers constitute themselves as 'subject' in saying 'I' and in contrasting themselves with 'you ${ }^{87, "}$ (TRAUGOTT, 2003:128). É, por conseguinte, apenas em contraste ao interlocutor que se torna possível a constituição de si mesmo como sujeito.

Em desenvolvimentos posteriores, Traugott (2010) defende que subjetividade envolve a expressão do self $f^{88}$ e da percepção ou ponto de vista do falante no discurso. Enquanto subjetificação, segundo a autora, é o processo através do qual expressões linguísticas adquirem significado subjetivo. Não podemos, contudo, nos esquecer de que Traugott (1989) já propusera que (inter)subjetificação é um processo semântico através do qual um elemento linguístico (morfema, palavra, sentença, construção) desenvolve novos sentidos a partir da perspectiva do falante. Particularmente, refere-se à tendência do material lexical de se tornar cada vez mais baseado no estado de crença subjetiva ou na atitude do falante/escritor frente ao que está sendo falado ou a como está sendo falado. É por isso que, em Traugott e Dasher (2005), encontramos a informação de que a subjetificação é o principal tipo de mudança semântica e atua no nível do discurso, através das escolhas linguísticas realizadas pelo falante/escritor.

Em seus desenvolvimentos mais recentes, Traugott (2010) nos inspira a verificar a hipótese de que elementos linguísticos subjetificados tendem a ocupar posições cada vez mais periféricas e a se deslocar. Essa hipótese é guiada pelo comportamento observado em línguas como o inglês que seguem a ordenação verbo - objeto. Imaginamos que, sendo o português uma língua SVC e, ainda, que a ordem sintática é mecanismo funcional para a construção de subjetividade e intersubjetividade, avaliar a posição preferencialmente assumida pela construção quase e os valores contextuais nas variadas posições seja uma tarefa inadiável neste trabalho.

Considerando que a intersubjetificação constitui-se como processo através do qual significados vêm, com o passar do tempo, a codificar explicitamente ${ }^{89}$ a atenção do falante/escritor ao self do ouvinte/leitor, então expressões dessa natureza nos auxiliam a identificar sentidos epistêmicos que expressam a atitude daquele em relação a este e

\footnotetext{
${ }^{87}$ Falantes constituem-se como 'sujeitos' ao dizerem 'eu' e ao se contrastarem com 'você'. (tradução sugerida)

${ }^{88}$ Seu próprio 'eu'. (tradução sugerida)

${ }^{89} \mathrm{O}$ que ocorre quando os novos significados (inter)subjetivos são codificados convencionalmente por formas, com novos pares forma-significado como resultado.
} 
também no sentido social, ou seja, quando aquele reconhece este como elemento participante da cena comunicativa. A relevância que aqui se apresenta é a ideia de que a intersubjetificação surge da subjetificação. De acordo com Traugott (1989), a mudança começa quando o significado original codificado é enriquecido com valores pragmáticos. Esse estágio é rotulado de “fortalecimento pragmático". Entretanto, é apenas quando esse significado passa a ser associado convencionalmente àquela determinada forma que a subjetificação pode - ainda segundo Traugott - ser admitida como mudança linguística. O novo par forma-significado pressupõe reanálise da forma lexical/gramatical original. Complementarmente, o processo de intersubjetificação começa com a mudança de valores pragmáticos em contextos específicos e só pode ser plenamente considerado como uma mudança a partir do estabelecimento de um novo par forma-significado. Como afirma Traugott (2010), diferentemente do processo de subjetificação, intersubjetificação é encontrado apenas em línguas como o japonês que codificam significados honoríficos em pronomes.

Os processos de (inter)subjetificação frequentemente envolvem gramaticalização, mas são tipos diferentes de mudanças e podem ocorrer independentemente uns dos outros. Em casos de subjetificação lexical, por exemplo, não temos a ocorrência de gramaticalização, assim como em alguns processos de gramaticalização, não há subjetificação, mas, sim, outros mecanismos subjacentes. A coocorrência costuma verificar-se devido às semelhanças entre os processos: ambos envolvem (a) a mudança de um domínio mais concreto para um mais abstrato; (b) a perda inicial de especificidade para a aplicação em uma gama mais ampla de contextos; (c) a mudança, em muitos casos, de uma descrição de uma situação externa para aspectos avaliativos, perceptuais ou cognitivos de uma situação interna.

Portanto, segundo a proposta de Traugott e Dasher (2005), as noções de (inter)subjetividade permeiam as línguas sincronicamente, enquanto a (inter)subjetificação é o processo através do qual significados os quais codificam as perspectivas e atitudes do falante/escritor se desenvolvem, diacronicamente. Para ilustrar, os autores apresentam o desenvolvimento de advérbios em marcadores discursivos os quais carregam certa carga de intersubjetividade, uma vez que sinalizam conectividade entre os interlocutores, além de funcionarem como hedges ${ }^{90}$, empregados como forma de atenuar o efeito do conteúdo expresso. A palavra actually, por exemplo,

\footnotetext{
${ }^{90}$ Limitadores. (tradução sugerida)
} 
antes um advérbio de modo, passa a atuar como marcador discursivo, utilizada com o sentido adversativo/concessivo de "diferentemente do que você diz", desempenhando pragmaticamente a função de sinalizar a atenção dirigida ao interlocutor.

\section{Langacker}

Ao articular sua teoria sobre a maneira como a significação é construída, Langacker $(1987,1990,2008)$ defende uma visão subjetiva sobre o significado e enfatiza a forma como o conceptualizador constrói o evento descrito, a perspectiva por ele adotada, os elementos que coloca em evidência e aqueles colocados em segundo plano. Os conceptualizadores, ou sujeitos da conceptualização, segundo o autor, seriam o falante e o ouvinte, ainda que nem sempre eles atuem explicitamente nas expressões linguísticas produzidas na situação comunicativa, presentes, em alguns casos, implicitamente. Langacker trabalha com os conceitos de objetividade e subjetividade relacionados ao conceito de ground - termo que diz respeito ao evento de fala, aos seus participantes, à situação espacial e temporal do evento, entre outros. De acordo com o autor, se a expressão linguística fizer alguma alusão ao conceptualizador, através de categorias gramaticais, como, por exemplo, advérbios de lugar (aqui, ali, etc) e advérbios de tempo (hoje, ontem, etc), a representação, embora não chegue a ser objetiva, também não será totalmente subjetiva, já que o conceptualizador se mantém como referência implícita.

Para Langacker, as noções de subjetivo e objetivo são caracterizadas "relative to to the asymmetry between the observer in a perceptual situation and the entity that is observed $^{91 ”}$ (1985:120). Uma representação será construída com a máxima objetividade, para o autor, quando o ground for proeminente na cena comunicativa, tanto para o falante quanto para o interlocutor, ou seja, quando ele se tornar explícito no evento, como evidenciam o emprego de pronomes de $1^{\mathrm{a}}$ e $2^{\mathrm{a}}$ pessoas e como podemos observar no exemplo (2) a seguir. Assim como, para o autor, teremos máxima subjetividade quando o conceptualizador estiver totalmente implícito na cena comunicativa, como no exemplo (1), em que ele é também o ponto de referência e relata a cena a partir de sua perspectiva, apesar de sua presença ser implícita.

\footnotetext{
${ }^{91}$ relativamente à assimetria entre o observador em uma situação perceptual e a entidade que é observada. (tradução sugerida)
} 
(1) Vanessa is sitting across the table ${ }^{92}$.

(2) Vanessa is sitting across the table from $\mathrm{me}^{93}$.

Quanto ao fenômeno da subjetificação, Langacker postula que esta reflete uma mudança de uma orientação mais objetiva sobre um determinado evento para uma mais subjetiva. $\mathrm{O}$ autor apresenta os seguintes exemplos de emprego da preposição across para ilustrar sua proposta:

(3) Vanessa jumped across the table ${ }^{94}$.

(4) Vanessa is sitting across the table from Verônica ${ }^{95}$.

No primeiro exemplo, teríamos, segundo Langacker, uma representação construída objetivamente pelo conceptualizador que observa a cena e não é parte dela, já em (2), a preposição across sinaliza o movimento subjetivo do conceptualizador na localização de "Vanessa" com relação a "table" a partir de um ponto de referência. Teria ocorrido, então, uma subjetificação do sentido da preposição across: a partir de seu sentido de percurso espacial, ela passa a assumir o sentido de percurso mental. Nessa perspectiva, então, verificamos um jogo complexo e sincrônico de intenções subjetivas e intersubjetivas.

\section{Verhagen}

Alinhando-se aos trabalhos de Tomasello (1999, 2003), Verhagen (2005) defende que a espécie humana é a única capaz de assumir a perspectiva de seus coespecíficos, diferentemente dos demais animais, inclusive primatas. Verhagen enfatiza, ainda, que essa capacidade dos seres humanos de se identificarem com os outros deve refletir-se na codificação e interpretação de símbolos linguísticos e que, portanto, aspectos semânticos e sintáticos podem ser compreendidos a partir da compreensão de mecanismos e operações cognitivas realizadas pelo falante/escritor.

\footnotetext{
${ }^{92}$ Vanessa está sentada do outro lado da mesa.

${ }^{93}$ Vanessa está sentada no lado oposto ao meu na mesa.

${ }^{94}$ Vanessa saltou sobre a mesa.

${ }^{95}$ Vanessa está sentada no lado oposto ao de Verônica na mesa. (traduções sugeridas)
} 
Ainda inspirado por Tomasello, Verhagen define o conceito de subjetividade como caracterizado pela habilidade de perceber a si próprio e os outros como agentes intencionais. Aparentemente simples, esse é um processo complexo, na realidade, pois implica a conceptualização de um objeto sob a perspectiva de um sujeito, o qual apresenta pensamentos e crenças que se podem diferir dos demais, no sentido de ser pessoal e não compartilhado, o que se refere ao conceito de intersubjetividade postulado por Verhagen: a comunicação entre sistemas cognitivos, a interação entre falante/escritor e ouvinte/leitor com base em seus respetivos sistemas cognitivos, ou seja, as respectivas subjetividades. O conceito de objetividade, por sua vez, refere-se, para Verhagen, aos objetos na vida real.

Ênfase deve ser dada à ideia de Vergahen de que o uso da língua não se presta apenas a propósitos informativos, mas também argumentativos, já que a língua é usada para influenciar o outro, seus pensamentos, seu comportamento e, por outro lado, para responder a essas influências. $\mathrm{O}$ autor trata, ainda, da questão da negação, de suma importância para a presente pesquisa devido à polaridade negativa da construção quase. Verhagen postula que o recurso da negação deva ser compreendido como a coordenação entre sujeitos cognitivos, ou seja, entre conceptualizadores, e que, dessa forma, trata-se de um mecanismo intersubjetivo. O autor refuta, assim, o caráter objetivista que a negação tem recebido em análises semânticas tradicionais e expõe evidências para o caráter intersubjetivo por ele defendido ao analisar, por exemplo, os operadores argumentativos barely e almost.

\section{Nuyts}

Nuyts (2001) concebe a subjetividade como relacionada à evidencialidade de expressões epistêmicas, como, por exemplo, advérbios modalizadores. Para esse autor, a subjetividade diz respeito à maior ou menor evidência de que o falante dispõe para realizar seu julgamento epistêmico. Tratando, inicialmente, da díade subjetividade/nãosubjetividade, Nuyts acaba por propor a díade subjetividade/intersubjetividade. Quando a evidência de um determinado evento está disponível apenas para o falante, segundo o autor, temos um julgamento epistêmico baseado em aspectos de subjetividade, ao passo que, se a evidência estiver disponível para um grupo maior de pessoas, estará em processo um julgamento epistêmico baseado em aspectos da intersubjetividade. Assim, 
o autor afirma que a subjetividade "envolve a indicação por parte do falante de que só ele sabe (ou tem acesso) à evidência e tira conclusões a partir dela" (2001:393), enquanto a intersubjetividade "envolve a indicação por parte do falante de que a evidência é conhecida (ou pode ser acessada) por um grupo maior de pessoas que compartilham a mesma conclusão baseada nesta evidência" (id.ib.).

Segundo Nuyts, a (inter)subjetividade está presente tanto em contextos interacionais, nos quais o falante formula uma hipótese em resposta imediata ou em uma situação de contraste entre falante e ouvinte, os quais não compartilham a mesma informação, quanto em contextos discursivos e preferencialmente escritos, nos quais o autor apresenta pontos de vista que foram formulados anteriormente por si próprio ou por outros.

\section{A integração entre as propostas}

Como verificamos, Traugott e Dasher (2005) enfatizam que ambos os fenômenos de subjetividade e intersubjetividade estão codificados de forma explícita na expressão linguística. Entretanto, há aspectos discursivos que só podem ser compreendidos de forma parcialmente implícita, no sentido defendido por Langacker (1990), para o que ele denomina de ground. Portanto, pelo menos parte do significado do enunciado é construído a partir do que não está explícito na expressão linguística, mas que é concebido cognitivamente e contextualmente. Essa ideia será evidenciada no emprego da construção quase, como observaremos.

A principal diferença, entretanto, entre as propostas de Traugott e Dasher (2005) e Langacker (1990) relaciona-se aos elementos aos quais os termos (inter)subjetividade e subjetificação se referem. Enquanto Traugott e Dasher empregam esses termos para se referirem à forma linguística, propondo avaliar o grau de (inter)subjetividade e subjetificação das expressões linguísticas em si, Langacker os utiliza para tratar da atitude do falante que, para o autor, pode ser mais ou menos subjetiva.

Além disso, apesar de, ao tratarem do fenômeno da subjetificação, Traugott e Dasher considerarem-na como um processo de mudança semântica que leva em conta aspectos diacrônicos e Langacker analisar a questão sob uma perspectiva sincrônica, ambos apresentam um ponto em comum: consideram que esse processo se verifica por 
um ancoramento cada vez maior nos participantes da situação comunicativa, falante e ouvinte ou escritor e leitor, que se encontram implícitos ao evento de enunciação.

Verhagen (2005), na terceira proposta, também apresenta pontos comuns às abordagens de Traugott e Dasher e Langacker na medida em que postula que expressões como cumprimentos (Hi!), desculpas (Sorry!), vocativos (Hey!) são puramente subjetivas, uma vez que invocam implicitamente o ground, conforme defende Langacker, assim como marcadores de perspectiva epistêmica (probably) e expressões avaliativas (unfortunately) têm sua carga de (inter)subjetividade codificada explicitamente, como defendem Traugott e Dasher em relação aos marcadores discursivos. Estes, segundo os autores, atuam como sinalizadores de uma perspectiva que dirige a atenção a uma perspectiva já ativada no discurso.

Apesar de Nuyts não definir seus conceitos de (inter)subjetividade em termos de aspectos explícitos ou implícitos ao evento, seus exemplos parecem ir ao encontro do conceito de ground proposto por Langacker, visto que Nuyts relaciona a (inter)subjetividade à maior ou à menor evidência disponível para o julgamento epistêmico por parte do falante. A leitura mais subjetiva ou intersubjetiva de um determinado evento motiva-se por aspectos de ordem discursivo-pragmática, que se situam implicitamente na forma linguística.

Como pudemos notar, o sujeito lança, em forma de língua, suas intenções comunicativas como parte da codificação. Essa codificação atinge a sintaxe e reverbera no interlocutor, dentre outros, por meio do empenho da palavra (certeza, incerteza, dúvida, convicção sobre o que diz) e da valoração subjetiva (avaliação do que diz e da fonte da informação). Como estamos no plano do conteúdo e não propriamente centralizando a forma, talvez fosse mais apropriado tratar de modalidade.

Ao tratar da modalidade epistêmica, Givón (1995:114) chamou a atenção para a necessidade de se rever o contraste entre eventos realis e irrealis. Segundo ele, esses conceitos não podem ser definidos através do contraste, respectivamente, entre "real" e “irreal”. A oposição em questão deve ser entendida, segundo o autor, em termos de uma certeza subjetiva, propondo uma redefinição para a modalidade epistêmica, conforme segue:

a) Pressuposição: a proposição é assumida como verdade, seja por definição, por argumento anterior, por convenção, por ser óbvia a todos os presentes 
na situação comunicativa ou por já ter sido proferida pelo falante e não ter sido contestada pelo ouvinte.

b) Asserção realis: a proposição é fortemente declarada como verdadeira, mas a objeção por parte do ouvinte é considerada apropriada, apesar de o falante ter evidências para defender sua forte crença.

c) Asserção irrealis: a proposição é fracamente declarada ou como possível, provável ou incerta. $\mathrm{O}$ falante não está pronto para sustentar a asserção com evidências e objeção por parte do ouvinte é facilmente cogitada, esperada ou mesmo solicitada.

d) Asserção negativa: a proposição é fortemente declarada como falsa, mais comumente em contradição às crenças do ouvinte, explícitas ou assumidas pelo falante. Objeção do ouvinte é antecipada e o falante tem evidência para sustentar sua forte crença.

Os usos da construção quase e de sua parente distante quase que deixam ver que mais do que codificar a informação, o usuário lança mão de uma estratégia para falar sobre si e sobre a forma de acesso à informação, ainda que indiretamente. Sendo assim, examinar os padrões funcionais e deles depreender traços de modalidade nos ajudará a compreender um pouco mais sobre semelhanças e dissemelhanças entre os itens sob análise.

Explicitar os encaminhamentos adequados para lidar com os fundamentos, aqui discutidos, os quais nos permitirão compreender os usos de quase e quase que, também em suas nuanças intencionais, é o propósito do próximo capítulo. 


\title{
CAPÍTULO II
}

\section{Encaminhamentos metodológicos}

\begin{abstract}
Associar as ideias discutidas no campo da teoria a encaminhamentos metodológicos que satisfaçam as questões elementares de um trabalho científico é uma tarefa que exige grande reflexão e maturação. Este é o propósito deste capítulo: aliar o processo de maturação teórica ao exercício de busca de encaminhamentos analíticos suficientes e capazes de minimizar os esforços de modo científico. Trataremos das amostras que compõem o corpus, de como projetamos analisar os dados e das hipóteses que foram nos criando portas para a caminhada.
\end{abstract}

Trabalhar com o tema da cognição num campo linguístico pressupõe lidar com uma óbvia limitação: não temos acesso direto a ela, não possuímos equipamentos capazes de dividir os processos mentais em unidades menores para que nos fosse possível verificar como se processam os mecanismos que nos interessam. Temos, no entanto, acesso aos efeitos desses mecanismos, como, por exemplo, a construção contextual de itens e, numa instância mais alta de reflexão, a mudança linguística. Estudar o modo como esta se processa é uma maneira eficaz de entendermos como os indivíduos percebem, pensam e agem, uma vez que as decisões comunicativas baseiamse em analogias, associações, processos metafóricos e metonímicos, generalizações e outros mecanismos denunciantes do processamento mental.

O recuo no tempo é imprescindível para a melhor compreensão das funcionalidades assumidas pelas construções atualmente. Foi essa a motivação para o trabalho com cartas do século XIX, que compõem o corpus do Projeto História do 
Português do Brasil (PHPB), as quais tiveram as ocorrências das construções em questão extraídas para análise. São cartas escritas por redatores, provenientes de Críticas, queixumes e bajulações na Imprensa Brasileira do séc. XIX: cartas de leitores e cartas de redatores, de Barbosa \& Lopes (2004). De um total de 174 cartas, identificamos 4 ocorrências de quasi, como era grafado o item à época. Nas cartas escritas por leitores, também oriundas de Críticas, queixumes e bajulações na Imprensa Brasileira do séc. XIX: cartas de leitores. (idem, 2006), identificamos 13 ocorrências do item em um total de 62 cartas. Juntando esses documentos, resulta uma amostra de 236 cartas, das quais 17 ocorrências foram identificadas.

Por outro lado, dissertações vestibulares, em seu padrão prototípico, são redigidas por indivíduos que estão a meio caminho da norma escrita formal culta. Estão em formação e dependem de uma boa avaliação de seu texto para ingressar numa nova etapa, uma etapa mais abstratizada de raciocínio. Escolher, portanto, esse tipo de texto como amostra de dados garante-nos encontrar os casos inovadores (em sintonia com as inovações históricas das formas), os casos normativos (em sintonia com as regras do bom uso orientadas por cursinhos e professores durante toda a formação básica) e os casos fora do padrão (normalmente avaliados como erros pelos professores de português). Um erro, no entanto, se for representante da oralidade e de nichos sociais com potencial midiático podem ser também deflagradores de mudanças sociolinguísticas.

Realizamos, inicialmente, a análise de um conjunto formado pelas redações da Comvest (Comissão para o Vestibular da Unicamp) e da Fuvest (Fundação para o Vestibular da USP). Não tendo conseguido acesso a um número maior de redações de candidatos da Comvest - além daquelas presentes no site da instituição - decidimos não dar continuidade a seu uso em nossa pesquisa. Constituímos, então, um novo corpus sincrônico através das dissertações mais bem pontuadas $^{96}$ e pelas de pior pontuação redigidas por candidatos ao vestibular da Fuvest, referente aos anos de 2003 a 2011, no caso das primeiras, e aos anos de 2004 a 2011, no caso das segundas. Por não termos conseguido um maior acesso às redações de pior pontuação, que incluísse o ano de 2003, trabalhamos com as redações melhor pontuadas de um ano a mais. Entretanto, mantivemos um número aproximado entre os dois conjuntos: 381 bem pontuadas e 377

\footnotetext{
${ }^{96}$ As notas são derivadas de critérios atribuídos pela banca examinadora da Fuvest, todos professores de língua portuguesa. É necessário ressaltar que, muitas vezes, uma nota pior pode significar fuga ao tema e não necessariamente mau uso gramatical ou da norma culta. (ANEXO II)
} 
mal pontuadas. O trabalho com esse corpus nos permitiu ter acesso a uma amostra significativa de usos e representativa de indivíduos que visam a um objetivo comum de empregar o que consideram adequado e exemplar em termos de gramática ao longo de alguns anos, tal como seria o ideal para uma amostragem de tendências.

Ao consultar esse tipo de material já avaliado por uma banca, o objetivo era também o de verificar se haveria alguma possível correlação entre usos inovadores e avaliações negativas, já que é comum que bancas corretoras de redações pautem suas avaliações pela normatividade. Um uso inovador poderia ser interpretado como um erro e, obviamente, a avaliação seria negativa em função disso. Procedemos, assim, à verificação dessa possível correlação, considerando como alvo de verificação uma amostragem de 32 usos do item quase.

Para verificar em que medida o observado nas cartas, ao recuarmos no tempo, e nas redações dissertativas é regra geral e não estratégia pontual ligada ao contexto de produção, constituímos uma terceira amostragem de dados, uma amostragem de controle, por meio da qual estabelecemos um contraponto de resultados: resumos de dissertações de mestrado e de teses de doutorado e de livre-docência, defendidas na Universidade de São Paulo. Eles são identificados nos exemplos apresentados como "Resumos de teses".

Nessa incursão, detectamos 2040 ocorrências de quase, o que demandou que visualizássemos os resumos correspondentes, porém por restrições das ferramentas de visualização do site $^{97}$, foi-nos franqueado o acesso a somente 1000 resumos. Nesses, identificamos 1104 ocorrências de quase. Essa alta recorrência já é um indício da funcionalidade desse item mesmo em produções de escrita formal.

Ter acesso a esses três padrões (cartas de leitor e redator; redações dissertativas de vestibulares; resumos de teses e dissertações) favorece uma análise mais justa do fenômeno no sentido de reunir um amplo leque de exemplares para uma reflexão teórico-descritiva.

Recorremos, ainda, em momentos oportunos da pesquisa, quando se mostrou necessário o contato com ocorrências de determinados itens para melhor compreensão de suas funcionalidades, ao corpus do CETENFolha (Corpus de Extratos de Textos Electrónicos NILC/Folha de São Paulo), formado por cerca de 24 milhões de palavras em português brasileiro, criado pelo projeto Processamento Computacional do 
Português com base nos textos do jornal Folha de S. Paulo que fazem parte do corpus NILC/São Carlos, compilado pelo Núcleo Interinstitucional de Linguística Computacional (NILC).

No Capítulo III - “Quase e quase que: delimitação do objeto em sua tradição e inovação" - tratamos da categoria (de difícil definição) dos advérbios, especificamente, da ausência de definição que integre todos os membros dessa classe, das fronteiras instáveis e pouco nítidas entre seus componentes e aqueles de outras categorias, de sua característica mobilidade e flexibilidade, bem como de que modo quase a ela se encaixa (ou não). Na sequência das ações investigativas, realizamos um rastreamento histórico a partir de dicionários dos séculos XVIII, XIX, XX e XXI, objetivando a identificação de dados que pudessem referendar usos das construções quase e quase que para, no capítulo seguinte, descrever-lhes as propriedades funcionais.

O critério para a seleção dos dicionários foi o temporal, ou seja, precisávamos compor uma amostra que contivesse dicionários que mantivessem espaçamento temporal tal que garantisse a cobertura do maior período histórico possível. O primeiro e mais distante no tempo foi o dicionário de Bluteau $\left(1720^{98}\right)$, que, por sua vez, distancia-se no tempo da publicação do segundo, o de Caldas Aulete (1881). O tempo que os separa são 161 anos. O terceiro dicionário escolhido foi o de Lima (1946), distante 65 anos do anterior. Machado (1967), por sua vez, guarda 21 anos de diferença para o de Lima. Com dezenove anos de diferença temporal, o de Ferreira (1986) demonstrou-se bem representativo de sua época, por isso foi selecionado como quarto dicionário a compor a amostra. Com a nova edição dessa obra e ampliação de verbetes, selecionamos Ferreira (1999), que guarda treze anos de diferença temporal para sua edição anterior. Dez anos depois, outra grande obra fartamente consultada pela comunidade científica participa do cenário social brasileiro, que foi Houaiss \& Villar (2009), última obra a compor a amostragem. A motivação para guardar temporalmente a distância entre as obras assenta-se no fato de que os usos podem ter sido renovados, normatizados ou mesmo incorporados pela mídia. Essa estratégia favorecerá, assim, a constatação de expansão ou retração dos sentidos dicionarizados na língua portuguesa.

Cabe esclarecer que a técnica inicial de consultar obras lexicográficas vem sendo abonada pelos estudos sobre gramaticalização desde a década de 90, com resultados

\footnotetext{
${ }^{98}$ Este foi o primeiro dicionário de língua portuguesa a se valer de um corpus como base, constituído por 406 obras dos séculos XV a XVIII, inclusive alguns textos de autores contemporâneos de Bluteau.
} 
importantes. O argumento-chave para esse uso assenta-se no fato de que essas obras representam em seus verbetes e acepções usos correntes e frequentes na época de sua compilação. Sendo assim, pressupõe-se um trabalho prévio que nos abrevia o tempo de uma primeira checagem em documentos nem sempre acessíveis.

Ainda no Capítulo III, trabalhamos a etimologia dos componentes de quase (quam e si); o tratamento destinado à construção em questão em outras obras de estudo da língua; as funcionalidades assumidas por conjunções desde o latim clássico, passando pelo vulgar e chegando à língua portuguesa; os ecos do tratamento destinado à quase no ensino formal e, por fim, apresentamos um breve levantamento de dados realizado a partir do site Domínio Público ${ }^{99}$, como uma forma de referendação de cunho literário, de modo a deixar claro que o preconceito linguístico não tem fundo no uso, mas em mitos.

No Capítulo IV - "Em busca de laços vinculantes e dissociativos de quase e quase que" - traçamos um panorama de similaridades e diferenças entre a construção trabalhada e outras com as quais se aproxima e procedemos à análise dos diferentes corpora. Inicialmente, recuamos no tempo, trabalhamos com as cartas, para, depois, analisarmos as redações dissertativas, elencando as ocorrências em cada parte do texto (introdução, desenvolvimento e conclusão), com o objetivo de identificar a intenção por trás do emprego de quase nessas redações. Na sequência, foi realizada a análise da amostra de controle ${ }^{100}$ - resumos de teses e dissertações - e, a partir dela e dos outros corpora, a organização de padrões do item quase, mais especificamente, através da atuação do princípio de iconicidade ${ }^{101}$ e da verificação de uma subjetividade escalar entre os usos. As diferentes funcionalidades assumidas e os diversos escopos tomados foram analisados e, por fim, foi realizada a contabilização linguística.

Todo o corpus trabalhado na pesquisa é constituído de material escrito e o controle de dados será feito tanto quantitativa quanto qualitativamente. Algumas questões, como o reconhecimento de sua incorporação à escrita escolar, dependerão de uma abordagem quantitativa, com amostras de 2003 a 2011, o mesmo ocorrendo com o corpus de controle, o qual forneceu 1104 ocorrências de quase à pesquisa,

\footnotetext{
${ }^{99}$ Disponível em: http://www.dominiopublico.gov.br. (Data de acesso: 15/04/2014).

${ }^{100}$ Devido ao grande número de ocorrências distribuídos em cada padrão na amostra de resumos de dissertações e de teses, apresentamos somente algumas na seção reservada à análise. Os dados, em sua totalidade, contudo, serão apresentados no ANEXO I.

${ }^{101}$ Iconicidade remete à busca de identidade entre forma e motivações de uso.
} 
possibilitando uma contabilização linguística mais proveitosa. Ao mesmo tempo, quando estiver lidando com a descrição de padrões já identificados, adotarei a abordagem qualitativa. Por conseguinte, a abordagem adotada a cada passo será a que melhor responder ao tipo de questão formulada no exato momento das reflexões sobre dados e resultados. Se a quantidade oferece pistas de atração pelo mais proeminente na decisão sobre o que usar, o qualitativo permite recolher contextos típicos e atípicos que possam promover a mudança de uso.

E como a correlação qualidade e quantidade são relevantes para compreender como a mente seleciona usos, lidar com a questão da frequência nos parece proveitoso. Segundo Bybee (2007), o papel da repetição de uma construção é fundamental no processo de gramaticalização, pois é isso que a vai tornar automática como uma unidade, ou seja, o hábito gera automatização, que pode gerar emancipação - conceitos já apresentados nesta dissertação. Como postula Paul (1966:36), "toda a ação de falar, de ouvir e de pensar traz alguma coisa de novo. Mesmo a repetição exata duma ação anterior fortalece pelo menos certos elementos do organismo já existente".

Verificamos, assim, os padrões funcionais das construções quase e quase que encontrados em uso na língua e realizamos a contabilização linguística, averiguando o número de vezes que essas construções ocorrem nas amostras selecionadas. Para o analista, esses índices frequenciais tornam visível o processo de gramaticalização de uma construção, pois sabemos que o processo de evolução da gramática passa pelas pressões de frequência de construções quando os falantes tentam expressar e deixar mais claras suas intenções.

Entender o processo de deslizamento funcional da construção quase que pressupõe também lidar com a materialização linguística de processos intencionais e cognitivos, tal como postulado por Givón (2011). Esse é o motivo por que se torna imprescindível analisar a posição e mesmo seu escopo ${ }^{102}$ dentro da construção sentencial, testes tradicionais na descrição linguística de fenômenos sintáticos.

Empregar tais métodos de análise aos dados da língua neutraliza os aspectos problemáticos vinculados pela proposta da gramática universal inata, abordada anteriormente, que não apresenta explicações para questionamentos como: de que modo

\footnotetext{
${ }^{102}$ Refere-se ao nível de "cobertura” que uma determinada expressão linguística atinge nos domínios cognitivos acessados e quais porções desses domínios servem de base para o significado, ou seja, o escopo é a cobertura ou alcance que uma expressão tem naquele domínio.
} 
a criança aplica sua gramática universal abstrata às particularidades da língua específica que ela está adquirindo? Como seria possível à linguagem da criança passar por tantas e constantes mudanças ao longo de seu desenvolvimento, tendo em vista o caráter estático de sua gramática universal? Esses e outros problemas perdem sentido quando adotamos a linguística baseada no uso como forma de compreender a aquisição da linguagem. A atuação de habilidades cognitivas gerais explicam as constantes mudanças da linguagem adquirida pela criança e possibilitam a aquisição das especificidades de cada língua, a identificação de padrões de uso e a segmentação e decodificação de intenções comunicativas expressas em todos os tipos de itens e construções linguísticas. É essencial, portanto, que toda e qualquer análise linguística associe-se às motivações cognitivas.

O mais intangível numa análise que se pretende vincada pelo uso é a descrição das motivações e fatores potenciais às mesmas. Estabelecer recortes precisos no contexto de uso será a chave para essa tarefa, mas sempre corremos o risco de criar uma cisão indesejável, assim lidamos com a inconstância dos usos e com a fugidia codificação intencional, pois entendemos que nem sempre é viável lidar com a ideia de fatores absolutos quando se trata de estudo da língua. Nesse sentido, concordamos com Hopper \& Traugott (2003:63), quando postularam que:

\begin{abstract}
The phenomena that give rise to language chage are so complex that they will perhaps never be understood in enough detail for us to state precisely why a specific change occurred in the past or to predict when one will occur and if it does what it will be. Rather than referring to "causes" or "explanations", we speak more cautiously of motivations or enabling factors, understanding always that we are referring to potential not absolute factors ${ }^{103}$.
\end{abstract}

Assim, muitas vezes, recorreremos a tendências de uso, ainda que os resultados possam parecer categóricos quando destacados dos contextos analisados. Talvez seja prudente lembrar que, na perspectiva em que pesquisamos, língua é herança sociocultural e tratar de herança é deslocar-se para o campo da tradição e da ruptura na

103 Os fenômenos que dão origem à mudança linguística são tão complexos que talvez eles jamais sejam compreendidos o suficiente para nós afirmarmos precisamente porquê uma mudança específica ocorreu no passado ou para predizer quando uma ocorrerá e, se ocorrer, o que ela será. Ao invés de referir-se a "causas" ou "explicações", nós falamos mais cuidadosamente em motivações ou fatores favoráveis, compreendendo sempre que estamos nos referindo a fatores potenciais e não absolutos. (tradução sugerida) 
constante dinâmica do movimento gradual e abrupto para discutir as mudanças linguísticas, que seguem, paradoxalmente, um movimento gradual e lento. Esses movimentos dialéticos geram a impressão de caos e confusão, mas o uso é o que permite deles fazer a fotografia. 


\section{CAPÍTULO III}

\section{Quase e quase que: delimitação do objeto em sua tradição e inovação}

Segundo Pinker (2008[2007]), recorrer ao léxico analiticamente equivale a adentrar situações de usos e não apenas a ter acesso a uma lista de palavras. Ao nos decidirmos por analisar entradas e acepções em dicionários, visamos ao entendimento do contexto de uso e das significações incorporadas às formas por pessoas em situações específicas. É esse encaminhamento o ponto de partida para o conhecimento da trajetória de desenvolvimento de usos sobre quase e quase que no português brasileiro. Sendo esse o bilhete de ingresso à diacronia, não podíamos nos furtar a tratar da tradição cultural, da transmissão de usos de um modo mais formal. Por isso, também apresentaremos como esses itens são categorizados e, depois, como foram sendo esculpidas suas funções ao longo dos tempos. Seus traços mais fortes se tornarão indissociáveis de suas funções, razão por que será oportuno cotejar gramáticas normativas e saber como são apresentados aos mais jovens durante o período em que se apropriam da tradição, via escolarização. Para que esse estudo se torne mais plausível, elegemos também livros didáticos e manuais, que, espera-se, sejam ecos das gramáticas normativas. De toda essa incursão, recolheremos pistas para discutir seus reflexos nas redações vestibulares. 


\section{A categoria dos advérbios}

A categorização é uma estratégia cognitivo-social para a discriminação de intenções e não de palavras. As classes de palavras são resultado de exercícios de analogias. No ensino escolar, elas são consideradas algo exterior ao indivíduo, o qual deve decorá-las como classes fechadas. Entretanto, com exceção da classe dos artigos ao menos sincronicamente - todas as outras são classes abertas. Lima-Hernandes et alii (2013:9) assim descreveram a classe dos artigos:

Talvez a classe de artigos possa ser concebida como uma classe fechada somente se a olharmos também de modo estrito, voltando-nos para sua função: marcador de classe substantiva. Se a olharmos num recorte histórico-formal, verificaremos que ela também foi se especializando a partir de outra classe, mais concreta, a dos pronomes. Daí a riqueza e dinamicidade da língua: ela acompanha, em sincronia, os indivíduos e esconde nessa superfície as demais camadas evolutivas.

Na base da categorização das classes de palavras estão dois princípios básicos: economia cognitiva e estrutura de mundo percebida. A primeira garante que o conhecimento que o indivíduo possui seja utilizado como matéria-prima para resolver problemas de classificação; a última é estratégia empregada como forma de perceber outros elementos, fatos, ações e eventos. Ambas são guiadas pela busca de menor esforço cognitivo e pela estrutura da experiência humana.

Intrinsicamente relacionado a esses conceitos está o processo de reconhecimento da presença de um atributo ou propriedade comum a outras palavras, o que as tornaria similares em comportamento e, portanto, com tendência de ser englobadas em uma mesma classe. Esses são os princípios atuantes na categorização linguística. Os membros da classe dos advérbios, entretanto, não compartilham totalmente os traços a ela associados. Com o intuito de melhor lidar com a heterogeneidade dessa classe de palavras - a qual a torna de tão difícil definição - recorremos aos conceitos postulados por Labov (1973) a respeito da delimitação de categorias e por Geeraerts (1989) sobre a teoria dos protótipos.

Segundo Labov (1973), há, entre as categorias, fronteiras imprecisas, de modo que categorias vizinhas não são separadas por limites rígidos, mas por zonas de intersecção, e que há, portanto, membros intermediários entre protótipos e fronteiras categoriais. Logo, a organização categorial envolve desde representantes mais centrais, 
com uma suficiente similaridade ao protótipo, até representantes mais periféricos, os quais apresentam poucos traços em comum com o núcleo categorial. Essa reflexão nos possibilita uma análise mais apurada da classificação e do próprio entendimento dos advérbios, uma vez que abarca também a análise de elementos periféricos, antes marginalizados pela abordagem categórica, como evidenciaremos mais adiante.

Geeraerts (1989), por sua vez, propõe que a teoria dos protótipos é, em si mesma, um conceito prototípico e apresenta quatro características que seriam consideradas como típicas da prototipicalidade: (i) categorias prototípicas não podem ser definidas por um único conjunto de condições necessárias e suficientes; (ii) categorias prototípicas possuem uma estrutura de semelhança por familiaridade, ou seja, sua estrutura semântica tem a forma radial de um aglomerado de sentidos sobrepostos; (iii) categorias prototípicas exibem diferentes graus de pertencimento de seus constituintes, ou seja, nem todos os membros são igualmente representativos; e (iv) categorias prototípicas têm fronteiras difusas. Ao refletirmos sobre essas quatro características, percebemos como podem ser aplicadas à categoria dos advérbios.

\subsection{Ausência de definição que integre todos os membros da classe}

O advérbio é visto, desde a tradição greco-latina, como termo invariável modificador de verbo. Algumas de nossas gramáticas estão, até hoje, impregnadas por vestígios desses conceitos - $O$ advérbio é, fundamentalmente, um modificador do verbo. (CUNHA \& CINTRA, 2001). Com a gramática de Soares Barbosa editada em Portugal em 1822, surge a visão, hoje difundida por muitas de nossas gramáticas, de que o advérbio modifica o verbo, o adjetivo e outro advérbio. Hoje, já existem muitos linguistas que estudam advérbios modificadores de toda a oração.

Adverb. A Word of a class whose characteristic role is traditionally that modifying a verb or a verb phrase: e.g. badly in He wrote it badly, where (in different accounts) it modifies either wrote or the phrase wrote it. (...) On the grammar of English and many similar languages, an adverb is effectively a word that modifies anything other than a noun. Thus badly above; certainly in Certainly I'll come, where it modifies I'll come ${ }^{104}$. (MATTHEWS, 2005)

\footnotetext{
104 Advérbio. Uma palavra de uma classe cujo papel característico é, tradicionalmente, aquele de modificar um verbo ou uma expressão verbal: ex: badly em He wrote it badly, no qual ele modifica tanto wrote quanto a expressão wrote it. (...) Na gramática do inglês e de muitas línguas similares, um advérbio
} 
Há também linguistas que, dirigindo-se pedagogicamente a estudantes, esclarecem a definição de advérbio revelando sua real dimensão:

Para entender o que vem a ser um advérbio, nada como principiar pela etimologia dessa palavra. Advérbio vem do latim ad + verbium, sendo que verbium deriva de verbum, "palavra". Como já vimos no estudo do adjetivo, a preposição latina ad quer dizer "perto de". Logo, advérbio é a palavra que se coloca perto de qualquer outra palavra. Certo?

- Não, errado! Aprendi que advérbio é a palavra que fica próxima do verbo.

- Aí se entendeu mal o latim verbum, que quer dizer "palavra", qualquer palavra. Depois, com o tempo, verbum passou a indicar uma das classes de palavras, visto que o verbo é considerado a classe de palavra por excelência. Mas isso ocorreu depois da "invenção" da palavra adverbium pela gramática latina.

- Tudo bem, mas e daí?

- Daí que, ocorrendo perto de qualquer palavra, e não apenas do verbo, o advérbio se tornou uma das classes mais ricas da língua, desenvolvendo uma quantidade enorme de sentidos.

(CASTILHO \& ELIAS, 2012:245)

A categoria de advérbios não pode, deste modo, ser definida a partir de um único conjunto de condições necessárias e suficientes. Essa "riqueza" é percebida na funcionalidade tão diversa assumida pelo item quase - um advérbio não prototípico do qual trataremos nas próximas seções.

\subsection{Estrutura de semelhança por familiaridade}

A percepção sobre a multifuncionalidade da construção quase parece um reflexo do que ocorre na classe dos advérbios. As palavras constituintes dessa classe, no entanto, possuem aspectos semelhantes que nos permitem classificá-las como familiarizadas. Assim, dentro dessa perspectiva, quando olhamos atentamente para os sentidos possíveis dos advérbios, deparamo-nos com aglomerados sobrepostos de sentidos que licenciam seus mais diversos usos e assim podemos falar em gradação.

é efetivamente uma palavra que modifica qualquer outra que não seja um substantivo. Como badly acima; certainly em Certainly I'll come, em que ele modifica I'll come. (tradução sugerida) 


\subsubsection{Graus de representatividade}

Imaginando-se um continuum cujos polos seriam o léxico - no qual estariam os substantivos e os adjetivos - e a gramática - onde se encontrariam, por exemplo, as preposições e os verbos auxiliares, a categoria linguística dos advérbios poderia ser considerada centro desse continuum, pois não é prototipicamente nem lexical nem gramatical. Tradicionalmente, considera-se que seja um dos traços prototípicos de uma categoria lexical ser uma classe aberta, enquanto categorias gramaticais seriam classes fechadas.

Cinque e Rizzi (2008), entretanto, chamam a atenção para o fato de que definir as classes fechadas como funcionais, em oposição a classes abertas como lexicais, é uma tarefa que se torna insustentável. Porém, torna-se possível se pensarmos em classes lexicais e gramaticais como um continuum e se colocarmos a categoria linguística dos advérbios como não representativa nem de uma nem de outra, baseando-nos em seus usos oscilantes entre significados mais representacionais do mundo - tal como o são (e isso evidenciaremos) os dados de quase classificados como menos subjetivos - e significados mais associados à interação entre falante/escrevente e ouvinte/leitor - tal como o caso dos usos mais subjetivos e intersubjetivos (e também isso pretendemos demonstrar). Logo, essa ideia de continuum precisa ser avaliada à luz da representatividade de palavras em relação às classes, justamente como Langacker (1987:16) defende: "membership is a matter of degree; prototypical instances are full, central members of the category, whereas other instances form a gradation from central to peripheral depending on how far and in what they deviate from the prototype ${ }^{105}$."

A categoria dos advérbios é reconhecidamente a mais heterogênea e, portanto, a de mais difícil definição. Assim, de acordo com Givón (2001), não surpreende que os advérbios sejam a classe que, translinguisticamente, apresenta menos aspectos universais, podendo estender-se pelos planos morfológico, léxico e sintático. Essa versatilidade, provavelmente, deve-se ao fato de os advérbios atuarem em um plano de utilização da língua que oscila entre o campo representacional, típico do léxico, e a área da gramática, relacionada à intersubjetividade, a qual se estabelece entre

\footnotetext{
105 Pertencimento à categoria é uma questão de grau; exemplos prototípicos são membros centrais e cheios da categoria, enquanto outros exemplos formam uma gradação do nível central ao periférico, dependendo de quão longe e em que se desviam do protótipo. (tradução sugerida)
} 
falante/escrevente e ouvinte/leitor e que, normalmente, se associa aos elementos de caráter gramatical.

\subsubsection{Fronteiras instáveis e pouco nítidas}

Há, além da ausência de definição para a classe dos advérbios, uma grande dificuldade em delimitar quais seriam os elementos que a comporiam. Quando confrontados com os chamados adjetivos adverbializados - os quais, ao atuarem como predicativos, esses permanecem invariáveis (propriedade que caracteriza a classe dos advérbios) - por exemplo, percebemos que não possuem uma fronteira nítida que os distinga de outras categorias linguísticas. É o que verificamos em exemplos, como: Ela fala alto, A cerveja que desce redondo, Ela jogou sujo com você etc. Não seria possível dar conta de classificar esses elementos em uma análise categorial dos advérbios, no entanto, em uma análise voltada à noção de prototipicalidade, podemos dizer que são elementos radiais, uma vez que não possuem algumas características do advérbio prototípico e compartilham características com outra categoria, a dos adjetivos. A ausência de um ou mais aspectos prototípicos dos advérbios não impede sua classificação como tal, apenas o afasta do centro prototípico ${ }^{106}$.

Os advérbios meio, quase e rapidamente, por exemplo, apresentam propriedades distintas. Apesar de serem os três invariáveis, apenas quase toma substantivos como escopo, meio e quase compartilham o atributo de modificadores de adjetivo e de verbo, enquanto rapidamente atua somente junto a verbos. A teoria dos protótipos admite que se estude uma palavra na classe em forma de rede de similaridades entrelaçadas.

\subsection{Ordem e mobilidade}

Cunha \& Cintra (1985:533-34) postulam que "os advérbios que modificam um adjetivo, um particípio isolado, ou um outro advérbio colocam-se, de regra, antes destes" e que os advérbios que modificam um verbo apresentam diferentes colocações a depender de suas classificações: advérbios de modo, segundo os autores, colocam-se depois do verbo; advérbios de tempo e de lugar, podem colocar-se antes ou depois; e

\footnotetext{
106 Como observaremos na seção seguinte, o advérbio quase não ocupa o centro prototípico dessa categoria devido, principalmente, à falta de mobilidade sintática por ele assumida.
} 
advérbios de negação devem sempre anteceder o verbo. Bechara (2004:290), ao tratar da categoria dos advérbios, ressalta sua flexibilidade:

Em geral, seu papel na oração se prende não apenas a um núcleo (verbo), mas se amplia na extensão em que se espraia o conteúdo manifestado no predicado. Isto lhe permite, em primeiro lugar, certa flexibilidade de posição não só no espaço em que se prolonga o predicado (com seu núcleo verbal), mas se estende aos domínios do sujeito podendo antecedê-lo ou vir-lhe posposto.

Na gramática pedagógica, Castilho \& Elias (2012:250) também tratam da colocação dos advérbios e postulam que seriam quatro as possibilidades: antes da sentença; depois da sentença; entre sujeito e verbo; entre verbo e seu complemento.

Neves (2000:254), que verticaliza a discussão, analisa a posição dos advérbios modalizadores, os quais já foram apresentados nesta dissertação como uma classificação dada, entre outros, à construção quase. Segundo a autora, esses advérbios podem aparecer antepostos quando incidem sobre um sintagma adjetivo, um sintagma verbal, um sintagma nominal ou pronominal. Quando incidem sobre um sintagma adverbial, podem ser antepostos ou pospostos, o que também ocorre nos casos em que o que temos é o advérbio modalizador incidindo sobre todo um enunciado: pode aparecer no início BASICAMENTE, Kennedy estaria sujeito à mesma paralisia de que Carter é vítima $\left(F S P^{107}\right)$ - ou no final do enunciado - As críticas - acaba de informar a nobre Senadora Eunice Michiles - foram feitas por três médicas, críticas candentes ao Governo, porque há um desespero, REALMENTE. $\left(J L-O^{108}\right)$.

Uma questão que se coloca é se essa mobilidade seria critério suficiente para classificar as construções quase e quase que entre os membros da classe de advérbios. Isso será avaliado mais profundamente com a incursão a dicionários e com o rastreamento histórico de dados, assim como com a análise de dados sincrônicos, no entanto já se verifica pistas que não se sustente. Sigamos com o estudo de Neves.

Na análise de Neves (2000:254), ao tratar da posição dos advérbios, observamos a palavra quase, nos exemplos apresentados, apenas em posição anteposta ao escopo:

\footnotetext{
${ }^{107}$ De acordo com as referências bibliográficas da obra, FSP corresponde à Folha de São Paulo.

${ }^{108}$ Discursos no Senado Federal.
} 
(1) Conheço QUASE todo este Estado, que não é tão grande como o de Minas. $\left(\mathrm{CJ}^{109}\right)$

(2) Nem espiar o movimento da rua ela podia, porque além das grades, que atrapalham, a janela é baixinha, a parede é grossa e o peitoril deve ter QUASE um metro de fundo. (AU $\left.{ }^{110}\right)$

(3) E um sonho é muita coisa aqui dentro... na cabeça mas fora, no dia-a-dia, um sonho é QUASE nada. (FEL ${ }^{111}$ )

(4) Você não é padre... ou já não é QUASE isso? $\left(\operatorname{SEN}^{112}\right)$

(5) Então, QUASE inaudivelmente, murmurou: “- Ele não quis vir, foi?”. $\left(\mathrm{A}^{113}\right)$

(6) Os antibióticos incluídos nesta categoria agem QUASE que exclusivamente sobre fungos. $\left(\mathrm{ANT}^{114}\right)$

Em Castilho \& Elias (2012:265), ao versarem sobre um grupo de advérbios por eles denominados como predicadores qualificadores - adicionam à classe sobre que se aplicam um traço semântico de que essa expressão não dispunha previamente ou então alteram algumas características dessa classe - apresentam o advérbio quase, definindoo como aquele que se aplica às expressões como "algo aproximativo". No exemplo fornecido pelos autores (2012:269), a posição é também anteposta ao escopo:

(7) A professora ela... no fundo ela é uma orientadora... porque quase sempre ela é procurada pelos alunos. (D2 SP 360) (CASTILHO \& ELIAS, 2012:269)

A decisão por uma anteposição ou posposição não é caótica. Ela é, sim, determinada por fatores pragmático-cognitivos: intenções são codificadas na língua e, para isso, diferenciam-se em padrões de codificação sintática. De acordo com Vlcek (2011:22), pesquisas em linguística funcional propõem uma tendência de o advérbio cujo escopo é o verbo - como no exemplo 8 - aparecer junto ao verbo; enquanto advérbios cujo escopo é toda a oração - o caso do exemplo 9 - tenderiam a assumir ordenações mais variadas, incluindo posições distantes do verbo.

\footnotetext{
109 Capitão Jagunço. DANTAS, P. São Paulo:Brasiliense, 1959.

${ }^{110}$ Não consta na seção "Textos examinados" da obra.

${ }^{111}$ Felicidade. CARLOS, M. Cap. 26 e 30, Novela Rede Globo.

112 O senhor do mundo. FARIA, O. Rio de Janeiro: José Olympio, 1957.

113 Ângela ou as areias.

${ }^{114}$ Antibióticos na clínica diária. FONSECA, A. L. 2ª ed. São Paulo: Epume, 1984.
} 
(8) As pesquisas indicam consistentemente que gays e lésbicas têm uma crescente aceitação na sociedade dos EUA ${ }^{115}$.

(9) Felizmente, a maioria dos incômodos da TPM podem ser amenizados com algumas mudanças no cotidiano ${ }^{116}$.

Apesar de ser comum às gramáticas escolares brasileiras incluírem os dois itens sublinhados na mesma classificação (advérbios de modo), é possível perceber algumas diferenças básicas entre eles. A primeira refere-se à posição sintática, já que o item consistentemente aparece próximo ao verbo e o item felizmente aparece afastado deste. A segunda, aos valores semânticos, já que consistentemente aparece com um valor referencial, mais objetivo, significando "indicar de modo consistente", enquanto felizmente se faz presente com um valor abstrato, mais subjetivo, transmitindo a avaliação do falante a respeito de sua asserção. Em termos teóricos, essas diferenças se explicam pelo princípio de iconicidade, em seu subprincípio de integração, defendido por Givón (1990): a tendência de se colocar adjacente sintaticamente o que é considerado também próximo cognitivamente. Temos razões para crer que a motivação para que a ordenação da construção quase se compreenda baseia-se nas motivações icônicas. Sendo assim, advérbios modificadores do verbo tenderiam a aparecer próximos do sintagma verbal, enquanto advérbios modificadores de toda a oração não seguiriam essa tendência. Verificaremos essa hipótese no capítulo seguinte.

\section{Rastreando a tradição do uso}

Para realização do rastreamento histórico de quase e quase que, recorremos à composição de uma amostra de obras lexicográficas. A ideia é recolher as acepções associadas a esses itens e desenvolver uma análise semântica que permita depreender seu traço semântico resiliente.

Em Bluteau (1720 $)^{117}$, encontramos a classificação da palavra quasi, grafia empregada à época para a palavra quase: advérbio. Analisando os exemplos que ele

115 Jornal O Globo, versão virtual, texto publicado em 3 de Agosto de 2009. (http://oglobo.globo.com/mundo/mat/2009/08/03/lideres-episcopais-de-la-sagram-dois-bisposhomossexuais - 757081753.asp)

116 Jornal O Globo, versão virtual, texto publicado em 3 de Agosto de 2009. (http://oglobo.globo.com/mundo/mat/2009/08/03/lideres-episcopais-de-la-sagram-dois-bisposhomossexuais - 757081753.asp) 
apresenta, notamos que hoje o classificaríamos com o valor discursivo-pragmático, já que sua função, nas sentenças, é modalizar algo que poderia soar impropriedade linguística (moderar) ou, ainda, soar uma aproximação (moderar ou emendar) reconhecida pelo falante como adequada. Esse julgamento seria feito com base em sua bagagem discursivo-pragmática:

QUASI. Adverbio, que ferve de moderar, temperar, \& emendar, o que no discurso poderia parecer impropriedade, ou encarecimento; como quãdo digo: A natureza he hũa quasi, ou como artifice do que obra; ou a Arte he hũa quasi, ou como natureza das cousas, que a affeyçoa. Quasi, \& às vezes, penè, ferè. Cic. Vid. Como. Vid. Perto: Vid. Pouco falta. (BLUTEAU, 1720: 25)

No exemplo oferecido para ilustrar essa categorização e funcionalidade, Bluteau emprega as palavras quase e como numa sequência informativa. Salvo engano, quase seria um aproximativo de uma definição prototípica e como seria um advérbio de modo em sua função prototípica de estabelecer uma comparação de igualdade, similaridade a essa definição: “A natureza é uma quase, ou como artífice do que obra”. Referenda esse raciocínio o segundo exemplo apresentado: "A Arte é uma quase, ou como natureza das coisas, que afeiçoa." Os exemplos que o autor seleciona dizem muito acerca de sua intuições sobre a língua: (i) o exemplo precisa de referendação histórica: e isso ele faz com dados latinos de Cícero; (ii) a entrada precisa de exemplificação sincrônica: e o exemplo trazido evidencia que as construções equativas, a exemplo de uma fórmula matemática, encadeiam duas sequências ligadas por um verbo ser não qualificativo.

As palavras ferè e penè são apresentadas, por Bluteau, como concorrentes de quase e já encerram seu uso numa função aproximativa. Essa interpretação é referendada pelo Dicionário Escolar Latino-Português, de Faria (1962):

ferè: adv. 1) Quase, mais ou menos, aproximadamente (Cic. Br. 150). 2) Quase sempre, ordinariamente, geralmente (Cic. Rep. 6, 10) (FARIA, 1962:393)

paene ou penè: adv. Quase, por um fio, a ponto de (Cic. At. 5, 20, 6) (FARIA, 1962:693)

Assim, quase é classificado como comparativo e aproximativo, sendo importante destacar que ambos os conceitos estariam imbricados. Comparamos, porque somos, em nossa base, analógicos. E, derivado do raciocínio analógico, concluímos que algo não é

${ }^{117}$ Esse dicionário foi produzido durante longo período e teve volumes publicados em mais de uma data. 
equivalente a outro, mas se aproximam em alguma medida. A ideia aproximativa, desse modo, resulta de um processo mais básico de comparar.

O interessante é que Bluteau também está atento aos gêneros discursivos e apresenta exemplos vinculando-os ao nicho social em que é empregado o item quase: na área jurídica, acompanhando substantivo, adjetivo e verbo.

\begin{abstract}
Quasi contrato, quasi força, quasi castrense, \& outras semelhantes palavras, que começão por quasi, são termos de Jurisconsultos. Quasi força he, se alguem occupar a posse da cousa vaga, que naõ fosse por outrem corporalmente possuida, a qual o possuidor cuydava ser alhea, \& depois achou que era sua. Vid. Liv.4. das Ordenaç. Tit 58 §. I. Quasi castrense he o que o filho familias adquirio por letras, ou por doação delRey. Vid. Livro 3. das Ordenaç. Tit. 9. §. 3. Quasi contrato, se póde provar por testemunhas, posto que a quantia delle passe de sessenta mil reis. Liv. 3. das Orden. Tit. 59 §. 22. (BLUTEAU, 1720: 25)
\end{abstract}

Esses exemplos evidenciam a produtividade do termo quase numa área muito desenvolvida e engendrada em toda a sociedade urbana, ainda que mais tradicional nos usos linguísticos. Um paradoxo se apresenta: a linguagem utilizada nessa área é hermética para o público em geral, mas suas ações têm impacto direto nas causas que envolvem direitos individuais. Sendo assim, não é difícil que essa terminologia tão frequente saísse de sua esfera terminológica e fosse apropriada por usuários da língua para outras situações em que a intenção fosse a mesma: a de modalizar ou de codificar um valor aproximativo da informação, ainda mais que os indivíduos que as empregam representam o padrão culto e formal da língua, à época associado ao belo e correto.

Mas nem só de formalidades sobrevive a língua, aliás é nas instâncias mais populares e repetitivas que a língua incorpora novos padrões, os quais podem se cristalizar. Um exemplo disso é o dito popular.

Como o ditado popular pode representar tecnicamente o produto do processo de repetições na situação de oralidade, constitui-se material interessante para se investigarem formas cristalizadas, ainda que não mais carreguem ou permitam depreender os originais contextos. Então, encontrar o emprego de quase num adágio pode denunciar um uso corriqueiro no cotidiano já à época da elaboração da obra lexicográfica de Bluteau. Foi o que encontramos ${ }^{118}$ :

O adagio Portuguez diz: Toda a terra he hua, $\&$ a gente quasi quasi.

(BLUTEAU, 1720: 25

${ }^{118}$ O que corresponde a: "Toda a terra é uma, e a gente, quase quase." 
Nele, verificamos a repetição da palavra quase sinalizando uma ideia aproximativa, com certa intensidade, favorecendo a interpretação da incerteza codificada pela atual construção quase que.

Em sua classificação, além dos valores aproximativos espacial e quantitativo, Caldas Aulete (1881) apresenta a iminência codificada por quase, que impede o efeito irreversível dos verbos (quase assustava; quase se formando).

qua.se adv. 1. Perto: A farmácia fica quase na esquina. 2. Por pouco: "...Sua nervosidade geral - corpo e espírito, era enorme, impressionava, quase assustava..." (Antônio Carlos Vilaça, $O$ nariz do morto) 3. Pouco menos de: A senhora tinha quase vinte gatos. 4. Prestes a: Júlio está quase se formando. [F.: Do lat. quasi.] (CALDAS AULETE, 1881:1056)

Também em sua classificação, Lima (1946) revela o valor aproximativo de quase, uma vez que todas as expressões por ele apresentadas - perto, proximamente; pouco menos; por pouco; como se - sinalizam graus de aproximação.

Quase, $a d v$. Perto, proximamente; pouco menos; por pouco; como se.

Quase-contrato (quase contracto), s. m. Compromisso voluntário, sem forma rigorosa de contrato. (Pl.: quase-contratos).

Quase-delito (quase-delicto), s.m. Dano causado por neglígência, sem intenção nociva. (Pl.: quase-delitos)

(LIMA, 1946: 1029)

Contudo, os exemplos só permitem afirmar que a aproximação relaciona-se a eventos e não a espaço físico ou tempo, embora, dada a abstratização da categoria "evento" aquelas estariam aí pressupostas. A palavra como, que já fora relacionada à quase por Bluteau (1720), aparece, neste momento, acompanhada por se em uma locução de valor discursivo-pragmático. A função desempenhada por como de estabelecer comparações - que seriam, de certo modo, também formas de aproximação, uma vez que dois conceitos são colocados lado a lado - parece ter sido amplificada. Ao se juntar a se e constituir a locução como se, a palavra como tem seu emprego ampliado a contextos mais abstratos, já que essa locução estabelece relações necessariamente entre ações e não entre objetos ou pessoas - conceitos mais concretos - como faz, apesar de não unicamente, a palavra como. Há, ainda, em como se, a combinação de uma noção de igualdade que figura no plano das possibilidades, portanto no tempo nãoagora, não-real, subjuntivo verbal. A presença de como se como sinônimo de quase pode nos sugerir que um caráter mais abstratizado e vinculado ao plano não-real tenha 
sido também por ela assumido à época da constituição da obra de Lima. Em seguida, o autor lista e classifica expressões compostas por quase juntamente a outras palavras contrato e delito. Nota-se que tais construções ligam-se intrinsicamente à área jurídica, justamente aquela à qual Bluteau referiu-se como sendo a mais produtiva em termos de frequência de emprego da palavra quase.

Em Machado (1967:1923), mais uma vez, como e como se aparecem associados semanticamente a quase. Dado que o valor aproximativo é muito produtivo nas línguas, as formas desgastam-se mais rapidamente, exigindo que novas formas sejam mobilizadas para desempenhar essa função. Machado evidencia essa dinamicidade de usos ao citar os possíveis sinônimos:

Quase, $a d v$. Do lat. quăš̆ (de quam si), <<como se; como; de qualquer maneira, por assim dizer; quase, aproximadamente〉>. Em 1460: <<quassy nada〉>, em Desc., I, p.586. Outras formas foram casi (séc. XV: <<Frey Graçiano casy falando sempre de Deus disse...>>, F. Men., I, p. 165), caise, caisi (<<em huũa leitura que capitollou de sam Framçisquo, que falava com Deus caise façe por façe...>, ibid., I, p. 11), que continuam em uso na linguagem oral; para outra formas vj.: D. M. C., s.v. acais.

quase-, elemento de composição culta que traduz as ideias de <<como se, supondo>>: quase-contrabando, quase-contrato, quase-delito, quase-usufruto.

Atentemo-nos à expressão de qualquer maneira apresentada pelo autor. Apesar de seu caráter também aproximativo, é possível perceber um valor de indefinição conferido pela palavra qualquer, gramaticalmente classificada como pronome indefinido - não presente nas outras palavras e expressões. Essa construção sugeriria significados como: 1. aconteça o que for, determinada coisa irá/precisa ocorrer, não deixará de ocorrer: "precisamos vencer/venceremos de qualquer maneira" 2. equivalente a de qualquer forma: "de qualquer maneira, isso não será possível” 3. de modo despreocupado (equivalente a de qualquer jeito): "não faça a atividade de qualquer maneira". Nota-se como os sentidos são totalmente opostos ao grau de certeza que sugere quase.

A classificação de Machado novamente se aproxima da de Bluteau ao apresentar a expressão por assim dizer, cuja funcionalidade pode ser definida do mesmo modo como este último categorizou quase: item empregado com o objetivo de modalizar algo que poderia soar impropriedade linguística. Machado também reconhece, portanto, a função modalizadora da palavra em questão. Ainda, o autor define-a como "elemento de composição culta" e a apresenta, assim como Bluteau e Machado, em expressões que se 
relacionam à área jurídica. É interessante também observar como o autor diferencia o uso de quase na linguagem oral - apresentando exemplos de cunho religioso - do uso culto, que, segundo ele, estaria restrito à área jurídica. $\mathrm{O}$ emprego do item em textos religiosos, uma esfera tão valorizada à época, leva-nos a levantar a hipótese de que este poderia facilmente ter sido levado a um uso mais frequente no cotidiano. Entretanto, a confirmação de tal hipótese exigiria, naturalmente, um levantamento de dados à época.

A expressão por pouco - já apresentada por Lima (1946) - se faz presente na categorização de Ferreira (1986), mas acompanhada por não, o que enfatiza a polaridade negativa da expressão. De fato, o item quase sinaliza uma negação: "Está quase em idade escolar", ou seja, não está em idade escolar ainda; "Quase enlouqueceu”, ou seja, não enlouqueceu. Essa polaridade de quase se deve ao valor de si, item de polaridade negativa, presente em sua raiz e por nós trabalhado posteriormente nesta dissertação.

quase. [Do lat. quasi, 'como se'] Adv. 1. Perto, aproximadamente. Está quase em idade escolar. 2. Pouco menos: Tem quase 1.500 livros. 3. Por pouco, não; por um triz, não: Quase enlouqueceu.

quase-contrato. $S$. $m$. Compromisso voluntário, sem forma rigorosa de contrato. $[\mathrm{Pl}$.: quase-contratos.]

quase-delito. $S$. $m$. Jur. Ato ilícito, culposo civil que gera a obrigação de indenizar. [Pl.: quase-delitos.]

quase-equilíbrio. S. $m$. Fís. Característica de um sistema que, não estando em equilíbrio, se acha num estado muito próximo de um estado de equilíbrio. [Pl.: quaseequilíbrios.]

quase-estático. Adj. Fís. - Quím. Diz-se de processo em que há equilíbrio entre o sistema e suas vizinhanças, e também no interior do sistema, em cada uma das suas etapas. [Pl.: quase-estáticos.]

quase-posse. S. f. Jur. Usufruto de direitos abstratos. [P1.: quase-posses.]

(FERREIRA, 1986:1427)

Ferreira lista, ainda, uma série de expressões compostas pelo item. Observa-se como, além de apresentar expressões pertencentes à área jurídica - quase-delito; quaseposse, que até então não havia sido listada pelos autores por nós pesquisados; quasecontrato, que, apesar de não ser classificada pelo autor como pertencente a essa área, nos parece estar a ela relacionada - Ferreira elenca duas expressões inseridas no campo da física - quase-equilíbrio; quase-estático. A palavra quase se mostra, portanto, cada vez mais produtiva também no léxico mais técnico ou especializado. Tal fato pode dever-se ao grau de certeza medial por ela apresentado quando ligada a qualquer outro item. Desse modo, temos elementos que nos conduzem a hipotetizar que quase se 
gramaticalizou. Entretanto, há ainda a possibilidade de o item estar desempenhando a função de prefixo lexical e, portanto, pode-se também intuir que ele tenha se gramaticalizado para depois servir de ferramenta à lexicalização de outras construções.

Em relação à edição anterior - e às acepções presentes neste trabalho - Ferreira (1999), em edição revista e ampliada, apresenta uma nova classificação: talvez; porventura, presentes em uma variante geográfica em Cabo Verde. A palavra quase, pela primeira vez, tem dicionarizado seu caráter de indicação de possibilidade, o que revela, ao menos, o reconhecimento de uma ampliação de seu emprego para demarcar conceitos mais abstratizados.

quase. [Do lat. quasi, 'como se'] Adv. 1. Perto, aproximadamente. Está quase em idade escolar. 2. Pouco menos: Tem quase 1.500 livros. 3. Por pouco, não; por um triz, não: Quase enlouqueceu. 4. Cabo-verd. Talvez; porventura: "Quero dizer: foi o que eles me contaram. Se é verdade... Mas quase não é." (Antonio Aurélio Gonçalves, Noite de Vento, p. 169.) (FERREIRA, 1999:1167)

O autor nos apresenta, ainda, uma composição bastante curiosa: quase-crioulo, que consiste em uma língua que possui características consideradas, normalmente, próprias dos crioulos, mas que, em sua história, desconhece-se a existência de fase identificável como crioulo. O item quase mantém, neste caso, seu valor aproximativo e compõe novamente uma expressão inserida em área específica: neste caso, a dos estudos linguísticos.

quase-contrato. $S$. $\boldsymbol{m}$. Compromisso voluntário, sem forma rigorosa de contrato. [Pl.: quase-contratos.]

quase-crioulo. S. m. E. Ling. V. crioulóide. [Pl.: quase-crioulos.]

quase-delito. S. m. Jur. Ato ilícito, culposo civil que gera a obrigação de indenizar. [Pl.: quase-delitos.]

quase-equilíbrio. S. $\boldsymbol{m}$. Fís. Característica de um sistema que, não estando em equilíbrio, se acha num estado muito próximo de um estado de equilíbrio. [Pl.: quaseequilíbrios.]

quase-estático. Adj. Fís. - Quím. Diz-se de processo em que há equilíbrio entre o sistema e suas vizinhanças, e também no interior do sistema, em cada uma das suas etapas. [Pl.: quase-estáticos.]

quase-posse. S. f. Jur. Usufruto de direitos abstratos. [P1.: quase-posses.]

Além dos valores de aproximação física (acepção 1) e de quantitativa (acepções 2 e 3), Houaiss \& Villar (2009:1586) incluem em sua categorização o caráter aproximativo referente a uma avaliação qualitativa: "a capelinha antiga está q. 
arruinada”. Pela primeira vez nesta análise, a palavra quase acompanha um adjetivo, indicando um grau de aproximação ao conceito por ele transmitido, o que permite compor uma avaliação de caráter qualitativo.

\begin{abstract}
quase $a d v$. (1460) 1 a pouca distância; próximo, perto <falou-lhe q. encostado ao ouvido $>2$ com ligeira diferença para menos < a produção agrícola q. ultrapassou a do ano anterior $>\mathbf{3}$ pouco mais ou menos; quando muito; aproximadamente <tem q. 90 anos $>\mathbf{4}$ um tanto < a capelinha antiga está q. arruinada $>\mathbf{5}$ por um triz, por pouco que não <ao vê-lo ensanguentado, q. desmaiou> $>$ q. que por assim dizer; verdadeiramente $<$ comprou uma terra com uma vista q. que perfeita $>$ GRAM / USO em novembro de 2008, a Academia Brasileira de Letras sugeriu que passassem a se grafar sem hífen as palavras que no português se iniciavam por quase empregado como el.comp. (p.ex., quase-contrato, quase-delito, quase-domicílio, quase-equilibrio, quase-estático, quaseposse e outras mais), por consenso com a $\mathrm{ABL}$, este dicionário passou a registrar as palavras compostas com quase como locuções; o Acordo Ortográfico de 1990 não menciona regra para esse uso • ETIM lat. quasi 'do mesmo modo que; como; pouco mais ou menos; como se; aparentemente' (HOUAISS \& VILLAR, 2009:1586)
\end{abstract}

A locução quase que aparece, finalmente, dicionarizada e classificada de modo bastante interessante, com uma funcionalidade que parece modalizar o discurso, constituindo-se uma locução de valor discursivo-pragmático. Apesar de não perder seu valor aproximativo, o item quase adquire, nesta locução, uma funcionalidade relacionada à intenção do enunciador de demarcar certo grau de descomprometimento: "comprou uma terra com uma vista q. que perfeita". Assim, podemos imaginar que tal vista tenha falhas e que não seja totalmente perfeita, entretanto, a hipótese mais plausível é a de que o enunciador, ao empregar quase que, tenha a intenção de não se comprometer com uma afirmação que poderia soar muito categórica ao referir-se a algo como sendo perfeito. A estratégia é a alteração de traços típicos de uma categoria semântica central. Podemos perceber a presença do rompimento de um valor categoricamente polar. O item sob análise mantém em todas as acepções um valor modalizador, rompido pela presença de polaridade negativa e de traço irrealis desde sua raiz, em que si se liga a quam, como podemos observar no itinerário histórico desses itens.

\title{
2.1 A tradição de uso: em busca de sua formação histórica
}

Recuar no tempo, para além de obras sincrônicas, permite conhecer as raízes semântico-formais dos itens sob estudo. É o que faremos a partir deste ponto. 
Em sua etimologia ${ }^{119}$, quase remete à junção do advérbio latino quam e da conjunção si. Ambos aparecem juntos na acepção de quam apresentada por Saraiva (2006:989):

Quàm si . PLAUT. O. m. q. Quasi. Citò quàm si... PLAUT. Tão depressa como se...

Identificadas como o mesmo que quasi, as palavras quam e si aparecem juntas em uma passagem e são traduzidas por como se. A conjunção se tem sua origem na conjunção si e o advérbio quam, como observamos a seguir, possui caráter comparativo. As seguintes acepções referentes a esses vocábulos foram identificadas por Ferreira (1988):

quam (quis), $a d v$. I. Interrog. e exclamativo: Quão, quão grande, quanto, a que ponto / / quam sit amicus attendite, Cic., vede quanto ele é amigo / / quam non multi!, Cic., quão poucos! II. Relativo. 1. (Em correlação com tam, expresso ou subent.) Quanto // tam cavere quam metuere, Cic., acautelar-se tanto quanto temer. 2. (Com superl. acompanhado ou não de possum). Quanto possível, o mais possível / / quam plurimas serpentes colligere, C. Nep., reunir o maior número de serpentes possível / / quam primum, o mais cedo possível. 3. (Depois de comparativo ou expressão comparativa). Do que / / filius fortior est quam pater, o filho é mais forte do que o pai / / doctior est quam putas, é mais culto do que pensas / / acrius quam diutius pugnatum est, C., combateu-se mais acérrima do que longamente. 4. (Com um número) Depois que / / quinto die quam..., no quinto dia depois que... 5. quam pro = proporcionalmente a. 6. quam qui ou quam ut = demasiadamente para, mais do que / / majora deliquerunt quam ut iis ignosci possit, Cic., cometeram delitos demasiadamente grandes para que se lhes possa perdoar. (FERREIRA, 1988:967)

O advérbio quam, em praticamente todas as acepções identificadas por Ferreira, possibilita em sua base uma interpretação de comparação ${ }^{120}$. Sendo sinônimo de quão e quanto, estando em correlação com tam em tam...quam (tanto quanto) e presente na construção quam pro (proporcionalmente), o advérbio é empregado em comparações de igualdade. Quam também sinalizará comparações de superioridade, quando a) acompanhar superlativos, como em quam plurimas serpentes colligere (reunir o maior número de serpentes possível); b) estiver presente depois de comparativo, como em filius fortior est quam pater (o filho é mais forte do que o pai); c) compor as

\footnotetext{
${ }^{119}$ A importância da etilomologia é referendada por Paul (1966:40): "o significado de uma palavra será determinado segundo a sua etimologia, embora a consciência desta etimologia já tenha desaparecido por completo e tenha sobrevindo uma evolução independente do significado."

${ }^{120}$ Del Nero (1997:74), que estudou as várias estratégias de comparação no nível do discurso, define esse mecanismo como "um meio para atingir um fim: conhecer, avaliar o mundo, compensar", constituindo, segundo o mesmo autor, uma atividade básica do ser humano.
} 
construções quam qui e quam ut (mais do que). Em apenas uma delas, o item não está imbricado à noção de comparação: 4. (Com um número) Depois que // quinto die quam..., no quinto dia depois que... . Infelizmente, por apresentá-lo incompleto, o autor impediu a compreensão total desse exemplo. Tornou-se difícil resgatar seu sentido, podendo-se apenas hipotetizar a seu respeito: haveria, possivelmente, uma comparação entre o quinto dia e os quatro dias antecessores em que se esperava que algo ocorresse, mas que só se manifestou nesse quinto dia.

A conjunção $s i$, que se teria unido a quam na constituição de quasi, tem sua acepção ligada ao valor irrealis, que pode ser codificado numa construção conjuntiva, tal como verificado em grande número de ocorrências.

si (arc. sei), conj. I. Com indicativo (suposição real): 1. Se, se porventura / / si possum, volo, Phaed., quero, se posso / / si pacem vis, para bellum, se queres a paz, prepara a guerra / / persequar, si potero, Cic., continuarei, se puder. 2. Se, todas as vezes que, quando / / si erat grandes vasum allatum, laeti afferebant, Cíc., (note o imperf.), todas as vezes que era encontrado um grande vaso, levavam-no alegres / / II. Com conjuntivo, suposição eventual e potencial (pres. e perf.), ou suposição irreal (imperf. e m. q. perf.). 1. Se, se por acaso, quando / / si hoc dicas, erres, se por acaso disseres isso, errarás / / si istius furorem ac tela vitemus, Cic., se evitarmos o furor e os galopes deste (= de formos capazes de evitar...) / / si hoc statueris, Cic., se tomares esta resolução / / si hoc diceres, errares, se dissesses isso, errarias / / si nihil litteris adjuvarentur, nunquam se ad earum studium contulissent, Cic., se em nada lhes fossem úteis as letras, nunca se teriam dedicado ao seu estudo. 2. Para o caso de, na hipótese de, na ideia de, a ver se (sobretudo depois de verbos que significam esperar, estar na expectativa, aguardar, fazer esforços,etc.) / / solvi fasciculum, si quid ad me essest litterarum, Cic., desembrulhei o rolo a ver se havia uma carta para mim / / conati si perrumpere possent, Cic., fazendo esforços na ideia de poderem abrir caminho. III. Sentido optativo e exclamativo: Ah!, se! Oxalá que / / o mihi praeteritos referat si Juppiter annos, V., ah!, se Júpiter me restituísse os anos passados! IV. Sentido explicativo: De que, que, de / / summa gloria constante ex tribum his, si diligit multitudo, si... Cic., a glória maior resulta destas três condições: de a multidão nos amar, de... e de... V. Sentido concessivo: Mesmo se, ainda que / / si ipse his facile careret, C. Nep., ainda que ele dispensasse facilmente estas coisas, VI. non si, nem se, nem ainda quando. Obs. Pode ser reforçada por advérbios: $s i$ forte, si modo, si quidem. (FERREIRA, 1988:1066)

Enquanto conjunção, si demarcava, então, predominantemente, "suposição eventual e potencial" - exemplificada por si hoc dicas, erres (se por acaso disseres isso, errarás) ou "suposição irreal" - como em: si hoc diceres, errares (se dissesses isso, errarias). A conjunção sinalizava também hipótese - solvi fasciculum, si quid ad me esset litterarum (desembrulhei o rolo a ver se havia uma carta para mim) e desejo (denominado "sentido optativo e exclamativo"): o mihi praeteritos referat si Juppiter annos (ah! se Júpiter me restituísse os anos passados!). A conjunção si já se 
apresentava, portanto, dotada de dois traços: polaridade negativa e traço irrealis. Suposições eventuais e potenciais, suposições irreais, hipóteses e desejos remetem ao plano da irrealidade.

No latim vulgar, si tem seu uso estendido para substituir as seguintes partículas interrogativas:

ne, partícula interrogativa enclítica colocada sempre junto da palavra sobre que recai a interrogação (FERREIRA, 1988:757);

nonne, part. interr. Não é verdade que? Porventura não? Obs. 1. Nas interrog. indirectas só aparece em Cícero e depois de quaero. 2. Supõe uma resposta afirmativa. (FERREIRA, 1988:771);

num, adv. interrog. 1. Acaso? Porventura? (Espera-se uma resposta negativa) / / num venit?, porventura, vem? / / num quid vis? , queres ainda alguma coisa? 2. (Nas interrogativas indirectas) Se / / quaero num venerit, pergunto se ele vem. Obs. Num tinha sentido temporal conservado em etiamnum e nunc (num + ce), mas perdeu-o e tomou um sentido interrogativo; nunc substitui num no sentido temporal (FERREIRA, 1988:777);

A ocorrência de si em frases interrogativas - e, provavelmente, principalmente, em interrogativas indiretas - propiciou seu emprego também como conjunção condicional. A adaptação a essa nova função faz sentido se pensamos no caráter de dúvida, incerteza, intrínseco à noção de condição. Ao funcionar como conjunção condicional, si passou a ser vinculada a um verbo principal de significação duvidosa, negativa, ou de questionamento, ou seja, verbos frequentemente pertencentes ao modo subjuntivo (de traço irrealis). Posteriormente, passou a ser empregada como conjunção integrante, entretanto, um traço de dúvida manteve-se em se, como uma pista, um vestígio de seu sentido primitivo.

Assim, operaram-se na palavra si mudanças gramaticais e semânticas. No âmbito gramatical, ao passar de conjunção condicional à conjunção integrante, si assume uma forma mais gramatical. Ambas as conjunções introduzem orações subordinadas e, por esse motivo, estão relacionadas a um conceito de maior dependência e a estágios mais avançados de gramaticalização.

\subsection{Tradição e seus ecos}

Por ter percebido a aproximação semântica entre quase e como, Jucá filho (1971) os classificou como sinônimos. 
Certamente, de começo, como, sinônimo de quase, tinha, como este, a significação de à maneira de, tal como no passo camoniano:

isto dizendo, irado e quase insano, sobre a terra africana descendeu (Camões Lusíadas, I, 77)

eis aqui, quase cume da cabeça de Europa toda, o Reino Lusitano, onde a terra se acaba e o mar começa (Camões, ib., III, p, 20)

e não eram elas mais que um instrumento quase inanimado (Bernardes, Floresta, IV, p. 222)

(JUCÁ FILHO, 1971:134)

Temos, nesta passagem, as ocorrências de quase mais antigas às quais esta pesquisa teve acesso: em Os Lusíadas (1572), obra do escritor português Luís Vaz de Camões e em Nova Floresta (1706/28), obra de Manuel Bernardes. Em ambos os casos, quase desempenha a função já assinalada aqui e tão presente em outros dados diacrônicos e nos sincrônicos os quais apresentaremos posteriormente: aproximativo de uma definição prototípica. Na primeira passagem citada da obra de Camões, o item demarca a proximidade ao conceito de insano, termo cuja significação é mais prototípica que a do anterior, irado, criando-se uma escala para descrever a gravidade do estado em que se encontrava a personagem em questão. Na segunda passagem da mesma obra, tem-se o emprego do item anteriormente a uma palavra cujo conceito também remete a uma categoria prototípica: cume (a parte mais elevada, o ponto mais alto de todos). Por fim, na passagem da obra de Bernardes, pretendendo demarcar a aproximação a uma afirmação prototípica - a de que elas, no caso do texto, as mulheres, não seriam mais que um instrumento inanimado - o autor emprega quase. Nos três casos, há a necessidade de "impressionar" o leitor em certo sentido, levá-lo a perceber, por exemplo, a gravidade de uma ira, o quão elevado estaria um reino em relação aos outros e o quão desumanizadas poderiam ser as mulheres em determinadas situações.

Em uma edição antiga de sua gramática, Cunha \& Cintra (1985:530) classificam quase como um advérbio de intensidade e apresentam-no no seguinte trecho:

\section{REPETIÇÃO DO ADVÉRBIO}

Como a do adjetivo, a repetição do advérbio é uma forma de intensificá-lo:

Vê-se logo logo a intenção! ....

(M. da Fonseca, $S V, 30$.)

- Pois não lhe digam nada, mas vão buscá-lo, já, já, não se demorem.

(Machado de Assis, OC, I,800.)

E estive quase quase a ir de rastos, beijar os degraus da escada...

(Machado de Assis, OC, I, 689.) 
O modo como o escritor Machado de Assis empregou quase nos remete ao adágio registrado por Bluteau já no século XVIII, cuja tradução seria: Toda a terra é uma, e a gente, quase quase. Em ambos os casos, o valor aproximativo do item é de fato intensificado. No adágio, a gente estaria bem próxima de ser uma só, assim como na passagem de Machado, o narrador estivera bem próximo de cair pelos degraus da escada. A intensificação ocasionada pela repetição de advérbios fica também bastante clara nos outros exemplos apresentados por Cunha \& Cintra (1985:539): a repetição de logo revela que a intenção demoraria muito pouco para ser vista, seria percebida quase de imediato, enquanto a repetição de já enfatiza a pressa com que os interlocutores do personagem a falar deveriam acatar a ordem a eles proferida.

Em sua Gramática de usos do português, Neves (2000:235), ao tratar da classe gramatical dos advérbios, apresenta-nos o quase, inicialmente, incidindo sobre um numeral: $O$ destino do Hospital do ex-IAPI também mudou, só que para pior para a contrariedade de seus QUASE 1.500 habitantes. $\left(C B^{121}\right)$. Após esse emprego mais concreto, o item aparece em outras ocorrências, quando a autora propõe a divisão da classe de advérbios, que, segunda ela, formam uma classe heterogênea quanto à função, em duas subclasses: advérbios modificadores e advérbios não-modificadores. Sendo quase um exemplo da primeira, abordamos brevemente as definições explanadas por Neves a respeito desta subclasse.

Afetando o significado do elemento sobre o qual incidem, os advérbios modificadores fazem uma predicação sobre as propriedades desse elemento, ou seja, modificam-no. Dentre as subclassificações destes advérbios, encontramos quase, que diferentemente do ocorrido em outras gramáticas, não foi classificado por Neves como um advérbio de intensidade, mas sim, como advérbio modalizador. De fato, Bluteau (1712-1728) já havia categorizado o item como um advérbio de valor discursivopragmático que teria a função de modalizar algo que poderia soar impropriedade linguística. Neves define assim os advérbios modalizadores:

(...) têm como característica básica expressar alguma intervenção do falante na definição da validade e do valor de seu enunciado: modalizar quanto ao valor

\footnotetext{
${ }^{121}$ De acordo com as referências bibliográficas da obra, CB corresponde ao Correio Brasiliense.
} 
de verdade, modalizar quanto ao dever, restringir o domínio, definir a atitude e, até, avaliar a própria formulação linguística. (NEVES, 2000:244).

Essa definição se aplicará muito bem aos dados dos corpora diacrônico e sincrônico, como veremos posteriormente. Em sua análise, Neves apresenta a ocorrência: O ferro já está QUASE afiado. $\left(B A^{122}\right)$. Uma vez empregado como modalizador, quase já assume um caráter mais abstrato do que aquele na ocorrência anterior.

Neves propõe, em seguida, subclassificações dos advérbios modalizadores, classificando quase, mais especificamente, como advérbio modificador modalizador delimitador $^{123}$ - aquele que delimita o ponto de vista sob o qual uma asserção pode ser considerada verdadeira. Na definição da autora:

\begin{abstract}
Esses advérbios não garantem nem negam propriamente o valor de verdade do que se diz, mas fixam condições de verdade, isto é, delimitam o âmbito das afirmações e das negações. O que ocorre nessa modalização é que o falante circunscreve os limites dentro dos quais o enunciado, ou um constituinte do enunciado, deve ser interpretado, e dentro dos quais, portanto, se pode procurar a factualidade, ou não do que é dito. (NEVES, 2000:250)
\end{abstract}

Realmente, nas ocorrências por nós identificadas, quase impõe um limite ao que está sendo enunciado. E esse limite, muitas vezes, se refere a uma categoria prototípica. Essa seria uma especificidade de quase. Por esse motivo, Neves (2000:251) faz uma ressalva em sua análise, mostrando-nos que embora a delimitação sugira principalmente redução de âmbito, ou restrição ${ }^{124}$, pode ocorrer de os advérbios delimitadores marcarem, como limite, um todo genérico ${ }^{125}$, e "essa generalização pode abranger nãoatingimento (com aproximação) de limite". Segundo a autora, seria exatamente esse o valor de quase. O não-atingimento nos faz pensar na noção de polaridade negativa, que será abordada ao longo da análise dos dados colhidos. Como exemplo de sua definição,

\footnotetext{
${ }^{122}$ Barrela. MARCOS, P. São Paulo: Global, 1976.

${ }^{123}$ Definição semelhante à de Castilho (2010:559): "advérbio qualificador delimitador". O autor afirma, ainda, que quase foi eleito pelos inquéritos do Projeto Nurc como o delimitador mais frequente.

${ }^{124}$ Como ocorre na seguinte ocorrência apresentada por Neves (2000:251): Já disse que quero passear PURA e SIMPLESMENTE, eu e esta donzela puríssima que tenho aqui ao meu lado. (Os dez. mandamentos. Vários autores).

${ }^{125}$ Como ocorre em: São EM GERAL terras ricas em ferro, em cálcio ou em fósforo. (Adolescência e sua educação. São Paulo: Ed. C.E.N., 1950. v. 52) (NEVES, idem).
} 
Neves (idem) fornece a seguinte ocorrência: Celeste QUASE não agradece. $\left(R E A^{126}\right)$. O emprego do item antes de palavras negativas é também tratado posteriormente.

Concluindo sua análise sobre quase, Neves (idem) assevera que este "pode facilmente ser entendido como subordinador, construindo-se com que". Temos, neste caso, a construção trabalhada por esta pesquisa: quase que. As ocorrências apresentadas pela autora neste caso foram: E sem maiores mágicas, QUASE QUE só dando palpites, suas idéias permitiram que o Santos ressuscitasse (...) (FSP $\left.{ }^{127}\right)$; Ele QUASE QUE literalmente esticava o pescoço para enxergar bem. $\left(\mathrm{CON}^{128}\right)$.

A construção em questão também se faz presente, curiosamente, no Novo Dicionário da Gíria Portuguesa, de Viotti (19-?, data incerta $\left.{ }^{129}: 366\right)$ :

quase que - $\mathrm{O}$ mesmo que quase; ex.: "quase que faleceu no desastre."

A classificação de quase que como gíria por um autor denunciaria um uso corriqueiro no cotidiano em situações de oralidade ${ }^{130}$. Trata-se de dado bastante interessante, uma vez que, em rastreamento histórico, identificamos seu emprego, já em 1887, em uma situação comunicativa escrita dotada de menor grau de formalidade, mais próxima ao âmbito da fala. Em textos mais formais do mesmo período, entretanto, foram identificados apenas usos de quase, nenhum de quase que. Em corpus sincrônico, detectamos o emprego da construção em uma situação comunicativa escrita que exige um maior grau de formalidade. Esse percurso, como veremos, pode ser sinalizador de um processo de gramaticalização em curso.

${ }^{126}$ Realidade.

${ }^{127}$ Folha de São Paulo.

${ }^{128}$ Concerto Carioca. CALLADO, A. Rio de Janeiro: Nova Fronteira, 1985.

${ }^{129}$ É possível ter uma ideia aproximada da data da obra, através dos anos de publicação da $1^{\mathrm{a}}$ e $2^{\mathrm{a}}$ edições: 1945 e 1956, respectivamente. A construção quase que foi identificada na $3^{\text {a }}$ edição da obra, a qual não apresenta data de publicação.

${ }^{130}$ No prefácio da $1^{\mathrm{a}}$ edição, o autor afirma: "Nós, os brasileiros, insistimos em conservar parada a mesma língua que no berço prossegue seu curso natural do ser vivo. [...] Êste dicionário não trata apenas dos verbetes da gíria nacional, pois, à medida que os colecionávamos, controlando-os com os mais recentes dicionários da nossa língua, encontrávamos repetidas lacunas de palavras, modismos, expressões que, não sendo propriamente da gíria popular, mereciam citados neste glossário, uma vez que não estavam ainda mencionados nos supra dicionários.”. No prefácio da $3^{a}$ edição, há a ressalva: "Já se encontram dicionarizadas algumas centenas de palavras compiladas pelo autor em época anterior ao aparecimento de novos e magníficos dicionários da língua.”. 
Em seu capítulo, Lima-Hernandes et alii (2013) classificam a construção quasi como um adjetivo qualificador, cuja propriedade intencional da classe, segundo os autores, teria sido cancelada e um significado aproximativo teria se manifestado. A construção em questão é exemplificada e acompanhada de outros adjetivos qualificadores de sentido aproximativo através dos seguintes dados:

Mas o exame de mestre era muito mais complicado ( ) o de arrais é uma espécie de exame de curso infantil (D2, SSA, apud Castilho, id., p. 90)

Este artigo tem sido traduzido destacado em quasi todas as lingoas da Europa; entre nós apparece um pouco tarde, mas ainda a tempo, porque o que é bom vem sempre a tempo. (PHPB, Carta de redator, XIX)

Agora, velhinho, suporto uma dor que é quasi superior às minhas forças e eue seo que a dor não é minha só. (PHPB, Carta de amor, XX)

Depois de um teórico período de experiência junto à firma de seu pai, o Toninho foi nomeado vice-diretor da empresa (apud Castilho, id., p. 90)

Esse presidente exibe uma relativa disposição para com os descamisados (apud Castilho, id., ib.)

(LIMA-HERNANDES et alii, 2013:25)

De acordo com esses autores, o efeito aproximativo causado por esses adjetivos qualificadores ao cancelarem as propriedades intensionais de seus escopos conduz o interlocutor à ideia de que a interpretação não pode ser estrita. Em outro momento, os autores apresentam outra ocorrência de quasi:

Uma paralysação quasi completa de negocios aliada a serias difficuldades nos recebimentos foram de modo tal enfraquecendo o commercio [Corpus PHPB, 13/09/1915).

(LIMA-HERNANDES et alii, 2013:28)

Segundo os autores, "completa" indica totalidade, a qual é, nesse caso, aproximada, em razão do graduador aproximativo quasi, e relacionada a "paralysação". A definição de quasi como graduador aproximativo nos chamou a atenção, uma vez que foi verificada na análise dos dados por nós levantados.

Na conclusão de sua análise a respeito dos adjetivos avaliativos, os mesmos autores afirmam que esses parecem representar, especialmente quando estão em posição pré-nominal, uma informação velha, já compartilhada pelos interlocutores, porém, muito provavelmente não consensual. Daí o caráter mais pragmático desses adjetivos, associado à função retórico-argumentativa. A construção quase, como verificaremos, 
assumirá a posição pré-nominal em praticamente todos os contextos e sua funcionalidade, de fato, coincidirá com a conclusão apresentada por esses autores.

\subsubsection{Classes elásticas e centralidade incerta}

Para melhor compreensão da etimologia de quase, recorremos à investigação da funcionalidade assumida pelas conjunções desde o latim clássico, passando pelo vulgar e chegando à língua portuguesa. Inicialmente, abordaremos as diferenças envolvidas no que se convencionou chamar de latim clássico e de latim vulgar. Temos consciência, contudo, de que essas línguas estão separadas, largamente, no tempo e no espaço. Essa consciência se estende ao uniformitarismo linguístico, cujo princípio prevê que fatos que ocorreram no passado ainda se manifestam no presente, ou por usos remanescentes e cristalizados em nichos sociais específicos, ou em usos vivos e correntes da língua atual. Também nos impele a essa incursão a ideia de que ações básicas e necessárias ao convívio humano são manifestadas em processos mais vívidos da língua, muitas vezes em termos de rotas universais de mudança, tal como preconizou Heine \& Kuteva (2007), referendado por vários linguistas, dentre os quais citamos Defendi \& LimaHernandes (2006); Lima-Hernandes \& Galvão (2007); Batista (2008); Barroso (2008); Cacciaguerra \& Oliveira (2009).

Em 1911, Löfstedt afirma que o latim vulgar deveria ser entendido como muito mais próximo da linguagem do povo ou da linguagem corrente do que do elevado modo de exprimir criado pela tradição e pela técnica literárias. A dificuldade de apreensão do latim vulgar é tratada por Silva Neto (1977:14), que assim a caracterizou: "a língua falada não se deixa fotografar, móvel e flutuante que é”. O autor é ainda categórico ao confrontar as línguas falada e literária e apresentar a dinâmica entre elas a partir de uma criativa metáfora:

A única espécie de língua que realmente existe é a falada. A língua culta, literária é artistificação dessa matéria. O seu aparecimento compara-se à justaposição de uma camada de gelo na superfície dos rios. Ela recebe deles a substância e, afinal de contas, nada mais é senão a própria água. Longe está, porém, de ser o próprio caudal. À primeira vista julgar-se-á que já não existe a corrente e que a água estagnou. Pura ilusão! - sob o bloco de gelo a nascente continua a fluir, seguindo as ondulações do terreno... E, logo que o gelo se quebra, lá torna a água a marulhar e a espadanar. A camada de gelo é a língua escrita. $\mathrm{O}$ frio que a produz e quisera estacionar a corrente é o esforço dos artistas e dos gramáticos. 
O latim, que no século VII antes de Cristo era a língua de pastores e agricultores, transformou-se com o refinamento da sociedade romana. $\mathrm{Na}$ literatura, muito contribui a língua grega, à qual os autores recorriam para tornar a linguagem de seus textos a mais rebuscada e complexa possível. Assim constituiu-se o latim clássico. Estava formada a camada de gelo. As línguas românicas, entretanto, como se sabe, não se originariam desse emprego do latim, como afirma Silva Neto (1977:52): “as línguas românicas entroncam-se, precisamente, no latim vivo, real", isto é, o latim vulgar. Segundo o autor, a língua literária da fase clássica foi tornando-se cada vez mais rigorosa em sua seleção de formas. A disciplina gramatical, portanto, estreitava-se, enquanto a língua falada seguia seu percurso natural. Com o tempo, notou-se a invasão dos elementos linguísticos que a escrita insistia em repelir, mas que "haviam continuado sempre o seu curso subterrâneo" (idem:181). Assim deu-se a vitória do latim vulgar e, consequentemente, o fato de ter-se originado nele o desenvolvimento das línguas românicas. A seguir, tratamos das funcionalidades assumidas pelas conjunções no latim clássico, no latim vulgar e na língua portuguesa.

No latim clássico, as conjunções funcionavam de acordo com a definição geral a elas dada nos últimos tempos: "palavras invariáveis que ligam duas orações ou partes coordenadas duma oração" (FREIRE, 1998:165). À época, a conexão entre as orações era descrita sob duas formas: (i) por coordenação - processo que une termos equivalentes pela natureza e pela função; e (ii) por subordinação - processo que une uma oração subordinada a uma principal. Podemos hipotetizar que só fosse possível aos estudiosos da língua daquele tempo reconhecer os processos polares e não outros mais graduais.

Vinculado à tradição literária da época, sempre preocupada com o rebuscamento da linguagem, lançando mão de períodos longos, complexos e elegantes, o latim clássico demonstrou evidente preferência pela subordinação em detrimento da coordenação. Havia, portanto, uma vasta variedade de conjunções, classificadas de acordo com os valores semânticos por elas desempenhados:

1. Condicionais: si (se); sin (mas se); siue (seja que); nisi, ni (se não, a não ser que); dum, modo, dummodo (contanto que); 
2. Causais: cum (como); quod, quia, quoniam (porque); quando, quaniam (visto que); siquidem, quandoquidem (visto que);

3. Consecutivas: ut non, quin (de tal modo que não); ut, uti (de tal modo que);

4. Finais: ut, uti, quo (para que); ne (para que não);

5. Concessivas: quamquam, etsi, tametsi, cum, ut (ainda que); quamuis, licet (posto que, embora); etiamsi (ainda quando);

6. Comparativas: ac, atque (como, assim como); quam (do que); tamquam si, ut si, uelut si, quasi, proinde ac si, proinde quasi (como se); ut, uti, sicut, sicuti, tam quam, uelut, ueluti (como, assim como); potius quam (antes que);

7. Temporais: cum, ubi (quando); dum, donec, quoad (enquanto, até que); antequam, priusquam (antes que); ut, ut primum, ubi, ubi primum, cum primum, simul ut, simulac, simulaque (logo que); postquam (depois que).

(ALMEIDA \& FIGUEIREDO, s.d.: 130-133)

A conjunção si, como podemos perceber, era bastante produtiva, tendo sua funcionalidade associada não somente ao valor semântico de condição, mas também ao ligar-se a outros termos - aos valores de concessão (etsi, tametsi, etiamsi) e de comparação (tamquam si, ut si, uelut si, quasi, proinde ac si, proinde quasi). Uma alta produtividade é também observada em relação ao item quam, associado à concessão (quamquam, quamuis), à comparação (quam, tamquam si, tam quam, potius quam) e ao tempo (postquam). A construção quasi já se fazia presente no latim clássico, classificada como conjunção subordinativa comparativa, aparecendo ou sozinha ou junto a proinde, formando a construção proinde quasi.

Observando-se especificamente as conjunções comparativas, notamos que a conjunção si uniu-se a vários elementos que, sozinhos, estabeleciam comparação, sendo traduzidos por como: tam quam, ut, uelut, quam e ac. Ao juntar-se a si, entretanto, essas construções passaram a codificar outro valor, sendo sinônimas a como se: tamquam si, ut si, uelut si, quasi, proinde ac si, proinde quasi. . Essa diferença semântica deve-se ao traço irrealis presente em si, que é vinculado ao uso do modo verbal subjuntivo aquele que expressa possibilidade, hipótese, dúvida. Diferentemente de como, a construção como se exige o emprego do subjuntivo (mais precisamente, do tempo pretérito imperfeito do subjuntivo).

Entretanto, apesar da relação de sinonímia entre quasi e como se, este significado não é reconhecido atualmente em quase. Prova disso é o fato de esse item ocorrer anteriormente à própria construção como se [Duas antíteses que combatem a tese, do presente ferrenhamente, QUASE como se fossem excludentes. (FUVEST, Redações dissertativas, 2004)]. Apesar de este traço não ser percebido pelos usuários da língua, ele persiste, faz-se presente na construção como pista. Não empregamos 
normalmente o modo subjuntivo ao utilizarmos quase, mas a análise de sua funcionalidade nas amostras selecionadas (séculos XIX e XX) nos leva a concluir que o traço irrealis, e as noções de dúvida e imprecisão a ele vinculadas, persistem. O motivo para esse não emprego do modo subjuntivo junto a quase mostra-se obscuro. Levantamos, no entanto duas hipóteses: a) o subjuntivo não é empregado pelo fato da presença de si (item que exige o subjuntivo) não ser percebida, b) já no latim, quase não exigia o subjuntivo. Esta última hipótese é sustentada pelo fato de o latim não ter sido uma língua tão redundante como o português e talvez, portanto, a presença de uma marca irrealis já fosse suficiente. A primeira hipótese é sustentada pela exigência do emprego do modo subjuntivo exercida por si em diferentes contextos no latim, como verificamos em Almeida (1985:341-343) e em Maurer Júnior (1959:182). De acordo com o primeiro, a conjunção condicional si fazia-se presente nos chamados períodos hipotéticos, que se subdividiam em:

hipótese real: quando a hipótese existe. $\mathrm{O}$ verbo da condicional ficava no indicativo, como em Si vis pacem, para bellum (se queres paz, prepara para a guerra);

hipótese possível: quando a hipótese pode existir. Ambos os verbos (o da oração principal e o da condicional) ficavam no subjuntivo, como em Si possim, faciam (se eu pudesse, faria);

hipótese irreal: sendo possível ou impossível, a hipótese é irreal, não existe - se eu quisesse... (mas não quero); se eu tivesse... (mas não tenho) - ambos os verbos ficavam no imperfeito do subjuntivo, como em Si dives essem, te adjuvārem (se eu fosse rico, te ajudaria).

Maurer Júnior (1959:182) ao tratar dos modos e tempos verbais do latim vulgar, afirma serem dois os tempos do modo subjuntivo: o presente e o mais que perfeito. Este último serviria, segundo o autor, para a expressão do passado do modo irreal, como observamos no exemplo: si non pluisset, exissem (se não chovesse, eu sairia).

Se a conjunção si exigia o emprego do modo subjuntivo, podemos hipotetizar que o não emprego desse modo verbal junto à construção quase estaria relacionado à inconsciência, por parte dos usuários da língua, da presença dessa conjunção. De fato, Lima-Hernandes et alii (2013) postulam que o uso favorece o desbotamento semântico, 
uma vez que o uso teria sido automatizado e, por isso, se tornado inconsciente e desbotado à consciência. Podemos dizer que o uso desgastaria alguns traços típicos esperados e projetados como certeiros pela memória do interlocutor.

Em relação à subordinação especificamente, o latim vulgar possuía bem menos conjunções do que o clássico. Além disso, o modo subjuntivo teria sofrido uma limitação nessa passagem, enquanto o indicativo teria se expandido. As conjunções subordinativas presentes no latim vulgar eram as seguintes, também segundo Almeida \& Figueiredo (s.d.: 130-133):

1. Condicionais: si;

2. Causais: quod, quia (e locuções, como per quod, pro quod, per quid);

3. Consecutivas: foram substituídas por quod.

4. Finais: foram também substituídas por quod ou quia.

5. Concessivas: não restou nenhuma das conjunções clássicas, uma vez que a concessão passou a ser expressa por construção assindética. No entanto, nas línguas românicas, surgiram várias locuções concessivas. $\mathrm{Na}$ língua portuguesa, por exemplo, temos ainda que, mesmo que, apesar de que.

6. Comparativas: as conjunções clássicas são substituídas por quomodo, que deu origem à conjunção como. Quam persistiu no latim vulgar, utilizada na comparação por desigualdade, mas foi, com o tempo, provavelmente confundida com quod e quia.

7. Temporais: apenas a conjunção quando sobreviveu. Nas línguas românicas, formaram-se locuções temporais a partir de quod. Como, por exemplo, logo que, desde que, até que, depois que.

De todas as numerosas conjunções do latim clássico, chegaram ao latim vulgar apenas a condicional si, a temporal quando, as comparativas quomodo e quam e, sobretudo, quod. A sintaxe do latim vulgar tornou-se mais clara e expressiva, justamente por mais simples. A questão que se levanta aqui é: de que modo outras construções surgiram para atender às necessidades comunicativas e desempenhar as funções (ou funções semelhantes) das conjunções que não chegaram ao latim vulgar? O mecanismo mais produtivo foi a criação de locuções conjuntivas a partir de junções 
entre quod - e, posteriormente, também quid - e preposições ou advérbios. A conjunção quod tornou-se, portanto, a conjunção subordinante por excelência do latim vulgar. Dará origem, como veremos posteriormente, à conjunção que no português - a de maior multifuncionalidade na língua.

As línguas românicas, por sua vez, apresentam menos conjunções do que o latim vulgar. Ao português chegaram e (et); ou (aut); nem (nec); quando; se (si); como; que. Como é próprio do processo de mudança das línguas, não foram criados vocábulos exclusivos para assumirem as funções das antigas conjunções latinas. As estratégias consistiram em adaptar construções já existentes para assumirem novas funções: (a) advérbios e preposições passaram a desempenhar a função de conjunção; (b) generalizou-se o processo - iniciado no latim vulgar, como vimos - que consiste em combinar a partícula subordinativa que com palavras de diferentes categorias, para a formação de locuções conjuntivas, como por exemplo: ainda que, logo que, sempre que, depois que, antes que, já que, assim que, mesmo que, até que, desde que, sem que, para que, de sorte que, de modo que, ao passo que, de forma que, à medida que, ao tempo que, dado que, posto que, suposto que, visto que. Como podemos perceber, advérbios, preposições e verbos na forma nominal do particípio juntaram-se à conjunção que para formar locuções conjuntivas no português. A respeito do surgimento dessas, Tarallo afirmou:

O sistema português, assim, no que toca aos processos hipotáticos de conexão sentencial, passou por um estágio de afunilamento (no sentido de que ter assumido basicamente todos os mecanismos hipotáticos existentes no latim) e de ampliação (com o florescimento das locuções conjuncionais).

(TARALLO, 1990:167)

A conjunção que, derivada, em parte, de quod, tornou-se, assim, o índice básico de subordinação da língua portuguesa, apresentando uma diversificada funcionalidade (integrante, causal, comparativa, consecutiva, relativa). Essa multifuncionalidade foi assim explicada por Câmara Júnior (s.d. 120):

(...) o advento da conjunção subordinativa que resultou primordialmente de um esvaziamento da significação pronominal da forma neutra quid do pronome indefinido-interrogativo e sua coalescência com a outra forma neutra quod, reservada ao pronome relativo. Secundariamente, houve a convergência da evolução fonética da partícula de conexão comparativa quam e da conjunção causal 
quod. De tudo isso, resultou uma partícula multifuncional que para os mais variados padrões frasais.

Said Ali (1964:221) aponta para a questão fonética, que impediria uma ligação direta entre quod e que, mas admite uma possível contaminação de várias formas:

(...) se não filiamos a integrante que diretamente à conjunção latina quod, por se oporem a isso as leis fonéticas, somos todavia forçados a admitir que o étimo verdadeiro, qualquer que fosse (quia, quid),teria, a partir de certa época, adquirido valor semântico igual ao daquela partícula, cursando então simultaneamente com ela na linguagem vulgar e acabando por suplantá-la.

Uma breve análise do itinerário histórico das conjunções desde o latim clássico, passando pelo vulgar e chegando ao português mostra-nos a coexistência de duas tendências contrastantes na língua: uma relacionada à drástica redução da quantidade de conjunções ao longo do tempo; e a outra, à ampliação dessa quantidade, causada pela adaptação de palavras de outras classes à função de conjunção e pela formação de locuções conjuntivas baseadas em que.

Tratando do fato de conjunções do latim terem assumido, entre outras, funções prepositivas, Paul menciona a conjunção quasi, cuja funcionalidade teria sido ampliada.

\begin{abstract}
Um atributo predicativo pode ter a mesma função que uma oração subordinada regida por uma conjunção. Em consequência disso, muitas conjunções podem anteceder também o simples adjetivo, o que leva a uma designação mais exata da situação. Assim sobretudo em inglês, talents angel-bright, if wanting worth, are shining instruments (Young); nor ever did I love thee less, thought mourning o'er thy wickedness (Shelley); Mac Jan, while putting on his clothes, was shot through the head (Macaulay) (9). Também em alemão podemos dizer: ich tat es, obschon gezwungen (fi-lo, embora obrigado), etc. Correspondentemente, em latim, colocam-se certas conjunções antes do ablativo absoluto, como quamvis iniqua pace honeste tamen viverent (Cícero) (10). As conjunções quasi e sive, que a princípio só podem ter servido para reger orações, passam a acrescentar-se, duma maneira geral, a simples membros de oração. (PAUL, 1966: 182)
\end{abstract}

O emprego de quasi com funções diversas já no latim seria indício de gramaticalização. Além da função prepositiva, a construção passou a funcionar ainda como advérbio, como pudemos verificar na acepção documentada por Bluteau. É percebida, ainda, a abstratização do conteúdo semântico: 
quam $($ conjunção comparativa $)+$ si (conjunção condicional $)=$ quasi (conjunção aproximativa)

quasi (conjunção aproximativa) $\rightarrow$ quasi (e) (advérbio modalizador) $\rightarrow$ quasi (e) que (locução)

Recorrer a dicionários mais recentes nos mostra que, apesar da abstratização sofrida, a ampliação semântica de quase foi restrita, ainda mais se levando em conta sua existência tão antiga desde o latim, como demonstramos anteriormente. Retomando menção já feita no cotejo com as acepções registradas em dicionários, inserimos aqui novamente o verbete apresentado por Houaiss \& Villar (2009:1586) a fim de analisá-lo sob outra ótica:

quase adv. 1 a pouca distância de; próximo perto (falou-lhe q. encostado ao ouvido) 2 com ligeira diferença para menos (a produção agrícola q. ultrapassou a do ano anterior) 3 pouco mais ou menos; quando muito; aproximadamente (tem q. 90 anos) 4 um tanto (a capelinha antiga está q. arruinada) $\mathbf{5}$ por um triz, por pouco que não (ao vê-lo ensangüentado, q. desmaiou) quase que por assim dizer; verdadeiramente (comprou uma terra com uma vista quase que perfeita)

As acepções explicitadas nos leva a refletir sobre o processo de abstratização, inerente, como postulado por tantos autores, à mudança linguística. Werner \& Kaplan (1963), por exemplo, ao apresentarem seu "princípio de exploração de velhos meios para novas funções", defendem que conceitos concretos são empregados para descrever fenômenos menos concretos e mais difíceis de serem conceptualizados. A construção em questão passa de conteúdos semânticos mais concretos - distância espacial (1); comparação numérica (2); aproximação quantitativa (3) - para mais abstratos aproximação qualitativa (4); avaliação qualitativa (5 e a locução quase que). O processo de gramaticalização de quase terá sido, portanto, acompanhado de mudança no tipo de unidade semântica sob seu escopo - como também será observado nas amostras de cartas do século XIX, nas redações do século XXI e nos resumos de dissertações e teses. Os deslizamentos funcionais processados por quase denunciam processamentos cognitivos operados pelo falante/escrevente no momento da situação comunicativa. Como é próprio do processo de gramaticalização, conceitos mais concretos foram mobilizados para a codificação de conceitos mais abstratos.

Apesar da grande proximidade semântica entre a acepção 5 e a locução quase que, é preciso ressaltar que esta última, além de sinalizar avaliação qualitativa, 
relaciona-se ao ato de fala, modaliza subjetivamente o discurso. Dentre as acepções, esta é, portanto, a mais subjetiva. Avaliações subjetivas, aliás, estão intrinsicamente relacionadas aos conceitos de evidencialidade e de modalidade epistêmica, mas não sabemos, ainda, se isso seria uma motivação para diferenciar funções dos itens sob análise. Vamos tratar desse tema no capítulo IV, em que também procederemos à análise das amostras reunidas como corpus.

\subsubsection{Ecos no ensino formal}

Aprovados pelo PNLD (Programa Nacional do Livro Didático), usados em larga escala por escolas brasileiras e já, até o momento, em sua sexta edição, os livros Português: Linguagens $-\sigma^{\circ}$ ano (CEREJA, W.R.; MAGALHÃES, T.C., 2008), Português: Linguagens $-7^{o}$ ano (idem), Português: Linguagens $-8^{o}$ ano (idem), e Português: Linguagens $-9^{\circ}$ ano (idem), e as gramáticas Gramática: texto, reflexão e uso (idem) e Gramática: teoria e exercícios (PASCHOALIN, M. A.; SPADOTO, N. T.; 2008) foram analisados sob o enfoque dos preceitos defendidos pelos PCN (Parâmetros Curriculares Nacionais), já apresentados brevemente, especificamente em relação ao tratamento destinado às construções codificadoras da intenções de incerteza, aproximação, imprecisão.

Em Português: Linguagens - $\sigma^{o}$ ano, a codificação em questão é tratada em dois momentos: em "Pronomes Indefinidos", conceituados como "aqueles que se referem a um ser ( $3^{\mathrm{a}}$ pessoa) de modo impreciso ou genérico" (CEREJA, W.R.; MAGALHÃES, T.C., 2008:67) e em cujos exemplos encontramos algum, nenhum, todo, qualquer, algo; e, posteriormente, na seguinte definição: “Quando temos um grupo de palavras com valor de pronome indefinido, nós o chamamos de locução pronominal indefinida", cujos exemplos foram Cada um dos convidados deverá trazer um prato; Quem quer que vá ao baile, deverá usar traje a rigor; qualquer um; seja qual for; quem for; todo o mundo (CEREJA, W.R.; MAGALHÃES, T.C., 2008:219). Codificações de imprecisão e incerteza são, portanto, ainda que bastante superficialmente, apresentadas ao aluno através deste livro didático. Não são, entretanto, efetivamente abordadas, não têm suas funções devidamente trabalhadas, não possibilitando, desse modo, que o aluno aprenda a empregá-las em suas produções comunicativas. 
O livro didático dedicado ao ano escolar seguinte, Português: Linguagens $-7^{o}$ ano (idem), propõe-se a trabalhar o conceito de advérbio e apresenta ao aluno o item tratado nesta dissertação: quase é classificado pelos autores como advérbio de intensidade e o seguinte exemplo é apresentado Ela já é quase uma mulher (CEREJA, W.R.; MAGALHÃES, T.C., 2008:65). O que, para nós, seria a codificação de um valor aproximativo, é categorizado pelos autores como intensidade, junto a formas como muito, pouco, bem, tão, tanto, bastante, mais, que parecem efetivamente sinalizar graus de intensidade, diferentemente de quase. O que temos em Ela já é quase uma mulher é uma ideia de iminência, em que o sujeito ainda não é uma mulher, mas está próximo de se tornar. Caso os exemplos de advérbio de intensidade apresentados fossem utilizados em sentenças semelhantes a essa, teríamos graus de intensidade, indicando "o quão mulher" o sujeito da oração seria: Ela é bastante mulher; Ela é mais mulher; Ela é bem mulher. Portanto, já seria uma mulher. Não estaria na iminência de ser.

Ainda tratando de advérbios, os autores introduzem aqueles que, segundo a classificação deles, codificariam incerteza: os advérbios de dúvida. Alguns dos exemplos dados pelos autores foram: talvez, possivelmente, provavelmente, acaso, quem sabe. É interessante observar como foram justamente essas construções - com exceção apenas de talvez - as menos frequentes nas redações dissertativas analisadas. Dentre os 758 textos, tivemos uma ocorrência de possivelmente, duas de quem sabe, oito de talvez e nenhuma de provavelmente. Além de podermos afirmar ser este um reflexo da modalidade falada, o tratamento tão superficial destinado a essas construções no livro didático é certamente um dos grandes responsáveis pela frequência tão baixa nas redações. Novamente, as funções assumidas pelas expressões no discurso não são trabalhadas e os alunos seguem não munidos da capacidade de compreensão da funcionalidade do que é a eles ensinado e de sua aplicação a situações comunicativas.

Nos livros Português: Linguagens $-8^{o}$ ano (CEREJA, W.R.; MAGALHÃES, T.C., 2008) e Português: Linguagens $-9^{\circ}$ ano (idem) construções codificadoras de incerteza, imprecisão ou aproximação não são tratadas. Desse modo, a abordagem a elas dedicada se restringe às breves passagens apresentadas nos outros livros, em meio às classificações de pronomes e advérbios. A gramática escrita pelos mesmos autores Gramática: texto, reflexão e uso - limitou-se a uma igual abordagem.

Em Gramática: teoria e exercícios (PASCHOALIN, M. A.; SPADOTO, N. T.; 2008), os mesmos advérbios são apresentados e, novamente, nem quase nem quase que 
estão presentes. A gramática apresenta, no entanto, uma classificação curiosa denominada "palavras e locuções denotativas", assim descritas: "não se enquadram em nenhuma das dez classes gramaticais. $\mathrm{A}$ NGB ${ }^{131}$ adota uma classificação semântica, ou seja, de acordo com o significado que elas expressam, por isso são chamadas palavras denotativas". Tem-se, desse modo, o reconhecimento, por parte desta gramática escolar, da necessidade de analisarmos determinadas construções de acordo com o significado por elas expresso.

Uma abordagem efetivamente funcionalista, entretanto, não foi observada em nenhum dos materiais analisados. Apesar da mudança de rumo prevista pelos PCN, o ensino proposto pelos livros e gramáticas examinados não se preocupa em abordar conteúdos gramaticais a partir de suas funções desempenhadas em uso real. As classes gramaticais continuam a ter suas propriedades puramente descritas em detrimento do trabalho que deveria ser realizado a partir de suas funcionalidades. A partir da abordagem atualmente adotada, não será possível aos alunos o desenvolvimento da percepção de que a língua não é uma estrutura estática e que deve ser concebida como uma atividade social, que não existe por si mesma, mas sim, devido ao uso para fim de interação entre os seres humanos e para a comunicação de intenções. A desassociação entre o ensino da gramática e o trabalho com a produção de texto, verificada nos mesmos livros e gramáticas analisados, coloca-se como outro problema. Ao ensinar a gramática de forma descontextualizada, desvinculada de uma situação comunicativa, ela se torna ainda mais complexa para os alunos, não levando a um aprendizado efetivo, como argumentado anteriormente nesta dissertação.

Permitir que a gramática seja abordada do modo como é atualmente nos livros didáticos e, muito provavelmente, nas salas de aula, contribuirá para que as dificuldades de aprendizagem dos alunos sejam mantidas. É preciso entender que tais dificuldades são, em muitos casos, fruto da concepção prescritiva da gramática tradicional que não se preocupa em apresentar a língua como uma estrutura maleável, não rígida. É obrigação dos professores de língua compreender e lidar com a gramática tradicional como uma grande obra de referência e apoio e nunca como a única fonte possível a partir da qual podemos fazer uso de nossa língua.

A conscientização a respeito dos processos de mudança subjacentes à língua, assim como suas regularidades, deve ser construída a partir da reflexão, da comparação 
de diferentes situações comunicativas - oral, escrita, formal, informal, padrão, não padrão - e da atribuição de novos sentidos. Ao invés de condenar os usos que seriam considerados como incorretos pela gramática tradicional, a perspectiva funcionalista propõe libertá-la de definições muito categóricas e adota uma nova forma de classificação, considerando as categorias gramaticais em um continuum, não separadas de forma rígida. Refletir a respeito das mudanças a que a língua é suscetível é fundamental. Como afirmou Laraia (2003):

(...) cada sistema cultural está sempre em mudança. Entender esta dinâmica é importante para atenuar o choque entre gerações e evitar comportamentos preconceituosos. Da mesma forma que é fundamental para a humanidade a compreensão das diferenças entre povos de culturas diferentes, é necessário saber entender as diferenças que ocorrem dentro do mesmo sistema. Este é o único procedimento que prepara o homem para enfrentar serenamente este constante e admirável mundo novo do porvir. (LARAIA, 2003:101)

É necessário, ainda, que professores se libertem do já tão desgastado lema de que haveria apenas uma única forma correta de se falar e que essa se pareceria com a escrita que seria, por sua vez, reflexo da fala. Essa supervalorização da escrita, que vem acompanhada de uma visão preconceituosa da fala, compromete o ensino da língua, na medida em que impede a possibilidade de se trabalhar com diferentes registros em sala de aula. O importante é demonstrar como cada modalidade apresenta suas características próprias, inerentes às circunstâncias em que ocorrem, e que o funcionalismo é um caminho bastante válido para o aprendizado efetivo da língua, uma vez que desenvolverá nos alunos suas habilidades cognitivas e comunicativas. Desenvolver atividades que contemplem a variação linguística observada em textos reais, falados e escritos, levariam o aluno a perceber a adequação de determinados empregos a determinadas situações, apreendendo, assim, a língua em uso.

Frei, um dos principais representantes da Escola de Genebra, vinculada ao funcionalismo, notabilizou-se por sua análise referente aos desvios da gramática normativa, que, segundo sua proposta, não são fortuitos, arbitrários, mas, sim, refletem tendências resultantes de necessidades comunicativas e constituem, portanto, uma rica fonte de estudos linguísticos. Esse seria o caso da construção quase que, condenada pela 
gramática normativa ${ }^{132}$, mas produtiva na língua em uso e atuante para atender a necessidades comunicativas diferentes - codificação de informações mais complexas e mais distantes cognitivamente - daquelas atendidas por quase.

Ocorre que nem tudo o que é condenado tem, de fato, um fundo de realidade histórica, mesmo dentro da tradição clássica. É o que evidenciaremos na seção seguinte, em que, brevemente, apresentaremos fontes de usos literários no Brasil e em Portugal, os quais incluem a locução quase que como estratégia comunicativa.

\subsubsection{Referendação de cunho literário}

A partir de levantamento realizado no site Domínio Público ${ }^{133}$, identificamos empregos de quase no valor aproximativo e de quase que em obras literárias no Brasil e em Portugal, publicadas nos séculos XIX e XX, o que nos levou a refletir a respeito do critério de seleção adotado sobre o que deve ou não figurar nas gramáticas de língua portuguesa. Lembremo-nos de que a tradição, nos estudos gramaticais, é demonstrada pelo uso corrente dos itens e expressões em obras literárias. Se encontramos o emprego subjetivo e intersubjetivo das construções em questão em obras literárias de autores famosos, os quais certamente poderiam ter sido recolhidos pelos gramáticos, talvez seja o caso de tratar-se de um problema de critério de seleção adotado. Por consequência, por não serem incluídas como exemplares nas gramáticas tradicionais, essas construções são encaradas como não contempladas como corretas nos livros didáticos, os quais tomam o que lá consta como restrição a outros usos.

Apresentamos, na tabela a seguir, o número de ocorrências de quase e quase que nas obras de diferentes autores e, em seguida, reproduzidos, os dados de quase que.

\begin{tabular}{|l|c|c|}
\hline $\begin{array}{c}\text { AUTOR, OBRA, ANO DE } \\
\text { PUBLICAÇÃO }\end{array}$ & $\begin{array}{c}\text { OCORRÊNCIAS DE } \\
\text { QUASE }\end{array}$ & $\begin{array}{c}\text { OCORRÊNCIAS DE } \\
\text { QUASE QUE }\end{array}$ \\
\hline $\begin{array}{l}\text { Pero Vaz de Caminha } \\
\text { A Carta }(1500)\end{array}$ & 11 & 1 \\
\hline
\end{tabular}

\footnotetext{
132 Como nos foi possível verificar em Bechara (1999:507): "Muitas vezes emprega-se que depois de advérbio onde a rigor poderia ser dispensado. São comuns as linguagens: talvez que, apenas que, felizmente que, oxalá que, quase que, enquanto que, embora que. Puristas têm condenado tais modos de dizer."

${ }^{133}$ Disponível em: http://www.dominiopublico.gov.br. (Data de acesso: 15/04/2014).
} 


\begin{tabular}{|c|c|c|}
\hline $\begin{array}{l}\text { Mestre João Faras } \\
\text { A Carta de Mestre João } \\
\text { Faras }(1500)\end{array}$ & 3 & - \\
\hline $\begin{array}{l}\text { Basílio da Gama } \\
\text { O Uraguai (1769) }\end{array}$ & 2 & - \\
\hline $\begin{array}{l}\text { Cesário Motta Jr. } \\
\text { A Caipirinha, Comédia em } \\
\text { tres actos (1847) }\end{array}$ & 3 & - \\
\hline $\begin{array}{l}\text { Alexandre Dumas } \\
\text { A dama das camélias } \\
(1848)\end{array}$ & 2 & - \\
\hline $\begin{array}{l}\text { Alexandre Herculano } \\
\text { A dama do pé de cabra } \\
(1851)\end{array}$ & 2 & - \\
\hline $\begin{array}{l}\text { Gonçalves Dias } \\
\text { Juca Pirama (1851) }\end{array}$ & 1 & - \\
\hline $\begin{array}{l}\text { Manuel Antônio de } \\
\text { Almeida } \\
\text { Memórias de um Sargento } \\
\text { de Milícias (1854) }\end{array}$ & 41 & 5 \\
\hline $\begin{array}{l}\text { José de Alencar } \\
\text { O Guarani }(1857)\end{array}$ & 65 & 1 \\
\hline $\begin{array}{l}\text { Casimiro de Abreu } \\
\text { As Primaveras (1859) }\end{array}$ & 7 & 1 \\
\hline $\begin{array}{l}\text { José de Alencar } \\
\text { Iracema }(1865)\end{array}$ & 2 & - \\
\hline $\begin{array}{l}\text { Machado de Assis } \\
\text { A chave (1867) }\end{array}$ & 2 & - \\
\hline $\begin{array}{l}\text { Castro Alves } \\
\text { Espumas Flutuantes (1870) }\end{array}$ & 5 & - \\
\hline $\begin{array}{l}\text { Bernardo Guimarães } \\
\text { A dança dos ossos (1871) }\end{array}$ & 5 & - \\
\hline $\begin{array}{l}\text { Machado de Assis } \\
\text { A chinela turca }(1875)\end{array}$ & 1 & - \\
\hline $\begin{array}{l}\text { José do Patrocínio } \\
\text { Motta Coqueiro ou A Pena } \\
\text { de Morte (1877) }\end{array}$ & 67 & 2 \\
\hline $\begin{array}{l}\text { Aluísio Azevedo } \\
\text { A Condessa Vésper (1882) }\end{array}$ & 65 & 2 \\
\hline $\begin{array}{l}\text { Camilo Castelo Branco } \\
\text { A Brasileira de Prazins } \\
(1882)\end{array}$ & 18 & 1 \\
\hline $\begin{array}{l}\text { Raul Pompeia } \\
14 \text { de julho na roça (1883) }\end{array}$ & 2 & - \\
\hline $\begin{array}{l}\text { Castro Alves } \\
\text { Os Escravos (1883) }\end{array}$ & 1 & - \\
\hline
\end{tabular}




\begin{tabular}{|c|c|c|}
\hline $\begin{array}{l}\text { Machado de Assis } \\
\text { A cartomante (1884) }\end{array}$ & 2 & - \\
\hline $\begin{array}{l}\text { Machado de Assis } \\
\text { A causa secreta }(1885)\end{array}$ & 2 & - \\
\hline $\begin{array}{l}\text { José do Patrocínio } \\
\text { A Campanha Abolicionista } \\
\text { (1885) }\end{array}$ & 11 & - \\
\hline $\begin{array}{l}\text { Júlio Ribeiro } \\
\text { A carne (1888) }\end{array}$ & 71 & - \\
\hline $\begin{array}{l}\text { Olavo Bilac } \\
\text { Contos para Velhos (1897) }\end{array}$ & 5 & - \\
\hline $\begin{array}{l}\text { Coelho Netto } \\
\text { A conquista (1899) }\end{array}$ & 6 & - \\
\hline $\begin{array}{l}\text { João do Rio } \\
\text { A alma encantadora das } \\
\text { ruas (1908) }\end{array}$ & 55 & - \\
\hline $\begin{array}{l}\text { Mário de Sá Carneiro } \\
\text { A Confissão de Lúcio } \\
\text { (1914) }\end{array}$ & 11 & - \\
\hline $\begin{array}{l}\text { Alberto Caeiro (Fernando } \\
\text { Pessoa) } \\
\text { Acordo de } \\
\text { subitamente (1914) }\end{array}$ & - & 1 \\
\hline $\begin{array}{l}\text { Bernardo Soares (Fernando } \\
\text { Pessoa) } \\
\text { Livro do Desassossego } \\
\text { (s/d) }\end{array}$ & 3 & 1 \\
\hline $\begin{array}{l}\text { Lima Barreto } \\
\text { O Triste Fim de Policarpo } \\
\text { Quaresma (1915) }\end{array}$ & 80 & - \\
\hline $\begin{array}{l}\text { Roberto Gomes } \\
\text { A casa fechada (1919) }\end{array}$ & 3 & - \\
\hline $\begin{array}{l}\text { Lima Barreto } \\
\text { Os Bruzundangas (1922) }\end{array}$ & 40 & 1 \\
\hline $\begin{array}{l}\text { Lima Barreto } \\
\text { Clara dos Anjos (1948 - } \\
\text { póstumo) }\end{array}$ & 76 & - \\
\hline $\begin{array}{l}\text { José de Alencar } \\
\text { A alma do Lázaro (1953) }\end{array}$ & 3 & - \\
\hline $\begin{array}{l}\text { Lima Barreto } \\
\text { Vida Urbana (1956) }\end{array}$ & 55 & 1 \\
\hline $\begin{array}{l}\text { Salomão Rovedo } \\
6 \text { rocks matutos \& } 1 \\
\text { romance rasgado. } \\
\text { Sambarrancho do bar } \\
\text { Jangadeiro. (1991) }\end{array}$ & 2 & - \\
\hline
\end{tabular}


(1) Levava Nicolau Coelho cascavéis e manilhas. E a uns dava um cascavel, e a outros uma manilha, de maneira que com aquela encarna quase que nos queriam dar a mão.

(Pero Vaz de Caminha, A Carta, 1500:4)

(2) Continuaram por tempos esquecidos, já estavam que não podiam de estafados; o nosso Leonardo, ajoelhado ao pé da fogueira, quase que se desfazia em suor. Afinal o major deu-se por satisfeito, mandou que parassem, e sem se alterar disse para os soldados, com a sua voz doce e pausada:

- Toca, granadeiros.

(Manuel Antônio de Almeida, Memórias de um Sargento de Milícias, 1854:13)

(3) Apenas passou o primeiro ímpeto e teve tempo de reflexionar, quase que começou a arrepender-se por não saber qual o meio de achar arranjo. Viu-se na rua, sem saber para onde ir, tendo por única fortuna uma bacia de barbear embaixo do braço, um par de navalhas e outro de lancetas na algibeira. Verdade é que quem tinha consigo estes trastes estava com as armas e uniforme do ofício; porém isso não bastava; o pobre rapaz estava em apertos.

(Manuel Antônio de Almeida, Memórias de um Sargento de Milícias, 1854:20)

(4) Vidinha caminhava tão depressa que a princípio o Leonardo quase que a perdia de vista; finalmente conseguiu alcançá-la, e começou a pedir-lhe que voltasse, fazendo as maiores promessas de comedir-se dali em diante, e de lhe não dar mais motivos de desgosto.

(Manuel Antônio de Almeida, Memórias de um Sargento de Milícias, 1854: 88)

(5) Até quase que estimou que lhe tivessem sentado praça; e bem dissemos nós que para ele não havia fortuna que não se transformasse em desdita, e desdita de que lhe não resultasse fortuna.

(Manuel Antônio de Almeida, Memórias de um Sargento de Milícias, 1854:94)

(6) - Ainda não Sr. major, observou a comadre, ainda não sabe do melhor, e é que o que ele praticou naquela ocasião quase que não estava nas suas mãos. Bem sabe que um filho na casa de seu pai...

(Manuel Antônio de Almeida, Memórias de um Sargento de Milícias, 1854:104)

(7) No íntimo de sua alma quase que aprovava a resolução de Peri; mas não podia afazer-se à idéia de perder seu amigo, seu companheiro, a única afeição que talvez ainda lhe restava no mundo.

(José de Alencar, O Guarani,1857:244)

(8) Eu era entusiasta então e escrevia muito, porque me embalava à sombra duma esperança que nunca pude ver realizada. Numa hora de desalento rasguei muitas dessas páginas cândidas e quase que pedi o bálsamo da sepultura para as úlceras recentes do coração; é que as primeiras ilusões da vida, abertas de noite - caem pela manhã como as flores cheirosas das laranjeiras!

(Casimiro de Abreu, As Primaveras, 1859:1) 
(9) Lanhoso, porquanto na pronúncia de primeira instância haviam sido desprezadas as formalidades mais curiais, pois que nenhuma testemunha depusera que o agravante se inculcasse D. Miguel para perturbar a ordem constituída, chamando o povo à revolta; e das respostas do agravante no interrogatório a que procedeu a autoridade administrativa, constava que o preso quase que fora obrigado por um clérigo estúpido e esturrado miguelista a deixar-se chamar D. Miguel I; mas não constava nem se provava que o agravante se aproveitasse de tal fraude e impostura para extorquir valores aos seus estúpidos cortesãos; o que decerto praticada um gamenho decidido a fingir-se D. Miguel para os espoliar.

(Camilo Castelo Branco, A Brasileira de Prazins, 1882:37)

(10) Os pais e mães, no intuito de darem desde a infância um exemplo à sua progênie, levavam consigo os filhos, e na velocidade de que precisavam dispor, quase que os arrastavam, ao som de ralhos impertinentes.

(José do Patrocínio, Motta Coqueiro ou A Pena de Morte, 1877:6)

(11) - O que foi isto, sá Antonica? que diacho de cousa! quase que foi para a cova; vejam que brincadeira.

(José do Patrocínio, Motta Coqueiro ou A Pena de Morte, 1877:90)

(12)Ambrosina sentiu fugirlhe a alma. Abraçou-

se ao amante num transporte de heróica solidariedade na desgraça, e durante muitos dias viveram os dois, quase que exclusivamente, para ler, por entre um dueto de suspiros e soluços secos, os boletins, as notícias, e os ardentes comentários da imprensa sobre a tre menda bancarrota. Maria Antonieta com certeza não se mostrara em público mais altiva mente resignada, quando perdeu o seu trono,nem tivera, ao lado de Luiz XVI, mais lind as palavras de dor, e lágrimas mais eloqüentes, do que as de Ambrosina aos pés de seu a mante arruinado.

(Aluísio Azevedo, A Condessa Vésper, 1882:280)

(13) Gabriel ficou quase que reduzido à roupa do corpo e ao dinheiro do bolso.

(Aluísio Azevedo, A Condessa Vésper, 1882:281)

(14) Da última vez, até, quase que um atrevido javanês puro consegue o primeiro lugar, tal era o brilho de suas provas; Pancôme, porém, arranjou as cousas tão lealmente diplomáticas que o rapaz perdeu a última prova.

(Lima Barreto, Os Bruzundangas, 1922:64)

(15) Acordo de noite subitamente,

E o meu relógio ocupa a noite toda.

Não sinto a Natureza lá fora.

O meu quarto é uma cousa escura com paredes vagamente brancas.

Lá fora há um sossego como se nada existisse.

Só o relógio prossegue o seu ruído.

E esta pequena cousa de engrenagens que está em cima da minha mesa

Abafa toda a existência da terra e do céu...

Quase que me perco a pensar o que isto significa,

Mas estaco, e sinto-me sorrir na noite com os cantos da boca,

Porque a única cousa que o meu relógio simboliza ou significa 
Enchendo com a sua pequenez a noite enorme É a curiosa sensação de encher a noite enorme Com a sua pequenez...

(Alberto Caeiro (Fernando Pessoa), Acordo de noite subitamente, 1914)

(16) Assim organizar a nossa vida que ela seja para os outros um mistério, que quem melhor nos conheça, apenas nos desconheça de mais perto que os outros. Eu assim talhei a minha vida, quase que sem pensar nisso, mas tanta arte institiva pus em fazê-lo que para mim próprio me tornei uma não de todo clara e nítida individualidade minha. (Bernardo Soares (Fernando Pessoa), Livro do Desassossego, s/d:13)

(17) Continuei estuporado e o meu amigo, ou antes, o nosso amigo parecia não ter qualquer surpresa com tão famigerado estudante.

- Sabe, disse este, quase que fui com o dôtô Lauro.

(Lima Barreto, Vida Urbana, 1956:30)

As ocorrências de quase - com grande variabilidade de escopos (adjetivos, verbos, advérbios, pronomes) - e, principalmente, de quase que, são fortes indícios de que o processo de mudança dessa construção já havia se instaurado à época acima referida. 


\section{Capítulo IV}

\section{Em busca de laços vinculantes e dissociativos de quase e quase que}

Durante a elaboração da fundamentação teórica, perguntamo-nos como teria surgido a construção quase que. Mostramos que o que nos difere na aquisição de conhecimentos é o efeito cumulativo e a transmissão de habilidades, intuímos, então, que esse mesmo modo seria a base para o surgimento da construção. Foram precisos deslizamentos funcionais ou contextuais de quase para que, cumulativamente, quase que se manifestasse. Uma parte dessa resposta foi composta, em doses homeopáticas, no capítulo em que procedemos à delimitação histórica do objeto. Hipotetizamos, durante as reflexões fundantes desta dissertação, que princípios funcionalistas guiariam as mudanças percebidas, conduzindo a que pelo menos parte da construção fosse formalmente similar à outra, ou seja, quase que traz em sua base formal a palavra quase, já presente remotamente entre os usos da língua portuguesa. A segunda parte da resposta deve ser, imaginamos, oferecida durante o exercício de identificação dos padrões funcionais de quase, que, em sua abstratização, deve ter incorporado traços e funções deflagradores de muito do que quase que hoje revela. Neste capítulo, nossa meta é responder que motivações distanciaram os usos de quase e os de quase que e, na mão contrária disso, que efeitos 
dessa abstratização contínua teriam responsabilidade pela ligação histórica entre quase e quase que na língua portuguesa.

\section{Panorama de Similaridades e Diferenças}

Como pudemos apresentar no capítulo anterior, a gradação funcional manifestase como forma de manutenção de traços (vinculação) e de alteração de classes (mudança na categorização). Isso não é novidade nos estudos linguísticos. Já em Hopper \& Traugott (1993:171), a gradualidade era demonstrada em termos de integração e de dependência semântico-pragmática (gramaticalização de combinação de orações) da relação entre as orações encadeadas ${ }^{134}$. Também não é novidade nas salas de aula em que se ensina língua portuguesa. Na Gramática do Português Brasileiro (Castilho, 2010), lemos que a palavra se atua como conjunção condicional e também como conjunção integrante em graus distintos de integração e de dependência entre as orações combinadas $^{135}$.

De tudo o que temos aprendido, o que se sobressai é que, além da mudança gramatical, opera-se a mudança semântica. Então, é através de um processo de metaforização que se desloca do valor semântico de X para Y. Mas não devemos nos esquecer: apesar da transferência metafórica, persiste em ambas as funções um traço resiliente que os mantêm vinculadas a uma trajetória de abstratização contínua. Foi assim que o conceito de questionamento, sinalizado por si em sua origem no latim vulgar, quando atuava como pronome interrogativo, metaforizou-se no conceito de

\footnotetext{
134 Postularam: parataxe (independência máxima e integração mínima); hipotaxe (interdependência e integração razoável) e subordinação (dependência e integração máximas).

135 São exemplos ilustrativos disso: (a) Se eu estudo, passo de ano. (CASTILHO, 2010: 376) e (b) O menino perguntou se o professor tinha saído. (CASTILHO, 2010: 356). Em ambos os períodos, as orações apresentam altos graus de integração e de dependência. Comparando-as, entretanto, verificamos maiores graus em (b) do que em (a). Em (b), a oração subordinada substantiva (se o professor tinha saído) e a oração principal ( $O$ menino perguntou) não estão unidas por um conceito específico, como ocorre com as orações subordinadas adverbiais, que se ligam à oração principal através de conceitos como tempo, causa, consequência, explicação, concessão, comparação, conformidade. Em (a), por exemplo, o que une semanticamente as orações Se eu estudo (oração subordinada adverbial condicional) e passo de ano (oração principal) é o conceito de condição. Assim, a substituição da conjunção se por outra de valor condicional exige apenas pequenas alterações no período e provoca pouca mudança semântica (Caso eu estude, passarei de ano). Porém, não podemos substituir a conjunção se em (b) com tanta facilidade. A dependência e a integração entre as orações assumem, então, neste caso, maiores graus, o que sinalizaria estágios mais avançados de gramaticalização, como afirmamos anteriormente.
} 
condição, quando a palavra passou a funcionar como conjunção condicional, vinculando-se, como afirmamos anteriormente, a um verbo principal de significação duvidosa, de questionamento ou negativa (codificação de polaridade negativa), e relacionando-se constantemente a verbos pertencentes ao modo subjuntivo (de traço irrealis). Essa polaridade negativa e esse traço irrealis persistiram apesar da ocorrência de mais um processo de mudança, quando o item passou a ser empregado como conjunção integrante, como pudemos observar nos exemplos abaixo identificados em um breve rastreamento no corpus CETENFolha ${ }^{136}$ por Nogueira (2013). Entre parênteses, a seção do jornal Folha de São Paulo em que o dado ocorreu:

(1) No caso de contusões, é possível que um médico da Fifa examine o jogador para avaliar se o corte é necessário. (CETENFOLHA ESPORTE, 1994)

(2) Enio perguntou se ele não tinha medo do comunismo. (CETENFOLHA OPINIÃO, 1994)

(3) Enéas ficou irritado quando um dos jornalistas que participava do debate perguntou se ele era fascista e o chamou de «exótico», mas riu quando Brizola perguntou se não era um exagero a previsão do Prona de gastar R\$ 170 milhões em sua campanha. (CETENFOLHA ESPECIAL, 1994)

(4) Ainda não sabemos se vai ter ou não inflação. (CETENFOLHA BRASIL, 1994)

(5) Ninguém o viu como eu vi, mas não sei se isso vai mudar a maneira de as pessoas encararem o Pelé. (CETENFOLHA ESPORTE, 1996)

(6) 'Representantes da federação deveriam ir lá antes do jogo para verificar se há algum problema', disse o técnico Luxemburgo. (CETENFOLHA ESPORTE, 1996)

O seu traço resiliente manifesta-se na composição sintática exigida: como conjunção integrante, se tende a ocorrer com verbos codificadores de questionamento, dúvida e incerteza, como observamos nos exemplos acima, ainda que breves: perguntou

\footnotetext{
${ }^{136}$ O CETENFolha (Corpus de Extratos de Textos Electrónicos NILC/Folha de São Paulo) é um corpus de cerca de 24 milhões de palavras em português brasileiro, criado pelo projeto Processamento Computacional do Português com base nos textos do jornal Folha de S. Paulo que fazem parte do corpus NILC/São Carlos, compilado pelo Núcleo Interinstitucional de Linguística Computacional (NILC). Recorremos a esse corpus, nessa pesquisa, em momentos oportunos, quando se mostrou necessário o contato com ocorrências de determinados itens para melhor compreensão de suas funcionalidades. Disponível em <http://www.linguateca.pt/cetenfolha/index_info.html>. Data de acesso: 07/10/2013.
} 
se; não sabemos se; não sei se; avaliar se (há incerteza quanto à necessidade do corte); verificar se (há incerteza quanto à existência de algum problema) ${ }^{137}$. A seguir, outros exemplos extraídos do CETENFolha:

(7) Só sei que são bancos americanos e europeus. (CETENFOLHA BRASIL, 1994)

(8) Eu sei que você já foi campeão mundial em 70, mas não foi como técnico. (CETENFOLHA ESPORTE, 1994)

(9) Eu sei que a morte do Ayrton abalou todo mundo. (CETENFOLHA ESPORTE, 1994)

(10) Além disso, sabemos que a ocupação lá é diferente da do MST. (CETENFOLHA BRASIL, 1996)

Atrelando essa discussão ao que vínhamos considerando como ponto de vista funcionalista no capítulo I, é patente que essa vinculação possa equivaler a um exemplo interessante de atuação do princípio da persistência, proposto por Hopper $(1991: 24)^{138}$, colocando-se como indício do processo de gramaticalização. Retomando as mudanças de $s i$, teríamos, nos deslizamentos categoriais operados, evidências desse processo: pronome interrogativo $\rightarrow$ conjunção condicional $\rightarrow$ conjunção integrante, com consequente abstratização funcional: questionamento $\rightarrow$ condição $\rightarrow$ dúvida.

Esses deslizamentos lentos e graduais tiveram agregado o traço irrealis de si ao caráter comparativo de quam, e esse contexto teve toda a condição necessária para que se concretizasse a passagem de um significado voltado a uma aproximação, uma vez que remeteria a uma comparação situada no plano da eventualidade, da irrealidade. Conforma-se, assim, uma comparação bem menos concreta, categórica, do que aquela estabelecida pela conjunção como, por exemplo. A título de ilustração, recolhemos um exemplo da amostra de redações dissertativas para análise:

\footnotetext{
${ }^{137}$ Nos exemplos explicitados, lidamos com o mundo da hipótese, da possibilidade: é possível que o corte seja necessário; é possível que ele tenha medo do comunismo; é possível que a previsão do Prona seja um exagero; é possível que tenha inflação; é possível que isso vá mudar a maneira de as pessoas encararem o Pelé; é possível que haja algum problema. O traço irrealis, portanto, está presente. A polaridade negativa, tal como ilustramos, também aparece. De fato, é difícil imaginar a não ocorrência da polaridade negativa em contextos que unem o verbo saber à conjunção integrante se. Por indicar incerteza, se aparecerá com "não saber", enquanto que, como conjunção integrante, aparecerá com saber.

138 "quando uma forma sofre gramaticalização passando de lexical a gramatical, alguns traços de seu sentido lexical original tendem a continuar, e detalhes da sua história lexical podem refletir no condicionamento da sua distribuição gramatical".
} 
(11) Um passado que é QUASE um desvanecer. (FUVEST, Redações dissertativas, 2004)

(11 a) Um passado que é COMO um desvanecer.

Verificamos que a similaridade entre os conceitos de "passado" e de “desvanecer" parece maior quando estabelecida pela conjunção como do que quando veiculada por quase. Nesse último caso, o que temos é uma aproximação. Ao empregar quase, indicamos que falta um traço para que esse "passado" seja um "desvanecer". O item pode, inclusive, ser parafraseado pelas expressões por um triz não ou por um traço não, nesse caso: Um passado que por um triz não é um desvanecer. Um passado que por um traço não é um desvanecer. No caso do emprego de como, essas paráfrases não são possíveis. Os conceitos são comparados, colocados em pé de igualdade.

Esse caso ilustrativo, contudo, não é excepcional nos usos linguísticos. Nogueira (2013) ilustra com um dado exemplificativo da mídia escrita:

(12) «Joguei como uma velha», lamentou a tenista. (CETENFOLHA, ESPORTE, 1994)

O fato de podermos parafrasear o item como, nesse caso, por do mesmo modo que («Joguei do mesmo modo que uma velha», lamentou a tenista.), revela-nos um alto grau de similaridade estabelecido por como. A despeito disso, é possível perceber a nuança semântica entre quase e como quando as colocamos justapostas:

(13) É quase COMO ouvir uma música em catalão. (FOLHA ILUSTRADA, 1994)

(14) Duas antíteses que combatem a tese, do presente ferrenhamente, quase COMO se fossem excludentes. (FUVEST, Redações dissertativas, 2004)

Nestas ocorrências, quase funciona como item de polaridade que quebra uma comparação categórica sinalizada por como, no primeiro exemplo, e pela construção 
como se fossem, no segundo. Os termos podem ser comparados à noção codificada por excludentes, porém não de forma perfeita. A ação pode ser comparada àquela de ouvir uma música em catalão, mas não precisamente, de forma imprecisa.

Para que todo o processo de mudança de quase ocorresse, desde sua etimologia, passando pelo emprego de quasi em contextos mais concretos, depois mais abstratos, a reconfiguração neural a cada emprego da construção foi necessária e a atuação da memória foi essencial. A recuperação de informações a respeito da construção torna-se possível a partir de seu repetido emprego.

Sobre o papel da repetição na memória, o artigo "Efeitos de relevância versus repetição de estímulo linguístico na indicação da memória declarativa" (BARROS et alii, 2011) apresenta interessantes ideias. A hipótese do trabalho é que a formação da memória declarativa poderia ocorrer através de ao menos duas estratégias: pela apresentação única de um estímulo considerado relevante para o sujeito ou pela apresentação repetida de um estímulo considerado irrelevante. Devemos considerar que o artigo baseia-se em testes aplicados pelos autores a estudantes: uma lista de informações, contendo informações consideradas relevantes para o grupo em questão e a repetição de outras consideradas não relevantes, era apresentada a esses. Depois, um questionário era aplicado e os estudantes respondiam a perguntas a respeito das informações apresentadas. Os resultados obtidos corroboraram a ideia de que a memória declarativa pode ser formada tanto através da repetição de estímulos irrelevantes, quanto da apresentação única de um estímulo relevante. As duas estratégias foram assim descritas pelos autores:

\begin{abstract}
Em um caso, o mecanismo envolvido é o de excitação repetida da(s) mesma(s) via(s) (sensorial, cognitiva e emocional), e no outro caso é o da excitação de diversas vias convergentes uma única vez (assumindo-se que no segundo caso haja maior número de vias convergentes envolvidas).

(BARROS et alii, 2011:10)
\end{abstract}

O que nos vem à mente é uma possível analogia com o processo de gramaticalização. Enquanto uma alta frequência (repetição) da construção em diversos contextos comunicativos é essencial, funcionando como válvula propulsora para que ela se gramaticalize, seu emprego em uma função inovadora - que será relevante para o interlocutor - também é necessário para que o processo tenha curso. 
Já o papel da reconfiguração neural pode ser compreendido se refletirmos a respeito da representação que temos de cada palavra/construção em nossa mente. Por exemplo, como seria feita a representação de "leão" no cérebro? Explicando, grosso modo, os passos seriam os seguintes, segundo Del Nero (1997:349): (1) um conjunto de neurônios (módulos) associariam a visão de um leão - o primeiro leão que a pessoa tivesse visto na vida - com a palavra (conjunto de fonemas) leão, que estaria em outro conjunto de neurônios; (2) tendo outros contatos com "leão" (vendo outros exemplares, ouvindo falar sobre outros), a palavra passaria a ser associada a outros conjuntos de neurônios, e assim, a cada vez que uma nova conexão se estabelecesse, algumas ligações seriam reforçadas. Essa reconfiguração neural ocorreria também a cada ocasião em que me deparo com uma construção linguística. Cada vez será diferente. E guiará o emprego em diferentes $\operatorname{contextos}^{139}$. O acesso às ligações já estabelecidas seria possibilitado pela memória, que seria, portanto, o mecanismo que aumenta a conexão entre propriedades. Os indivíduos mais espertos, sugere Gardner (1983:279), seriam aqueles mais capazes de estabelecer conexões entre diferentes domínios. E uma conexão não prevista é o que refina o processo de descoberta e invenção. Podemos supor que seria o que acontece, por exemplo, quando se instaura uma inovação linguística.

Outra atuação, cujo reflexo percebemos nas construções linguísticas selecionadas a serem empregadas, durante a fala ou escrita, é a da apresentação de evidências de que temos razão sobre determinado assunto. É o que vimos fazendo desde o primeiro capítulo dessa dissertação. E que estratégia preferimos adotar? Utilizamos aquela consagrada como eficiente para este tipo de trabalho: fazer referência a autores que sejam fonte de conhecimento na área a que nos vinculamos. A esse fenômeno intencional a Linguística nomeia evidencialidade. Esta permite identificar, em todos os meios linguísticos pelos quais o falante/escrevente se expressa, seu posicionamento a respeito da informação dada (WILLETT, 1988:51). Esse posicionamento, como afirma Willett, tanto é codificado em termos de gradação de confiabilidade do locutor na

139 Karmiloff-Smith (apud Mithen, 2003:89) emprega o termo "redescrição representacional". A consequência desse processo seria o surgimento, na mente, de "representações múltiplas de conhecimentos similares" e, assim, "o conhecimento se torna aplicável além do propósito especial para o qual é normalmente utilizado, e ligações perceptivas entre domínios podem ser geradas". Podem surgir, portanto, pensamentos que combinem conhecimentos que estavam "presos" no interior de seus domínios específicos. 
informação quanto pode ser apreendido nessa mesma medida por linguistas ${ }^{140}$. No português, as informações evidenciais são expressas, geralmente, via verbos modais, especificamente, os epistêmicos. Conceito semelhante à evidencialidade é a modalidade epistêmica, definida por Hengeveld (1989:138) como o meio através do qual o falante especifica o tipo (certeza, probabilidade, possibilidade) e o grau (forte, fraco) de seu comprometimento. Vejamos alguns exemplos de graus de certeza extraídos de uma das amostras analisadas:

(15) Ou seja PODE SER QUE suas atitudes de hoje possam destruir o que os primeiros imigrantes ingleses com muita luta fundaram um país no dia 4 de julho de 1776. (FUVEST, Redações dissertativas, 2004)

(16) Entretanto, observando certos fatos e aspectos do mundo atual PODE-SE DIZER QUE hoje há uma limitação excessiva (...) (FUVEST, Redações dissertativas, 2005)

(17) Assim sendo, PODE-SE AFIRMAR QUE a iniciativa do grupo Contra-filé é válida (...) (FUVEST, Redações dissertativas, 2005)

Além de poder, há o emprego do verbo modal dever como sinalização de modalização $^{141}$. A riqueza de formas é enorme. Gonçalves $(2003)^{142}$, por exemplo, identificou essa função na construção parece que, em que o verbo pleno parece - com o sentido de "ser semelhante" - une-se à conjunção que, passando a assumir funções equivalentes à de advérbio e codificando modalidade epistêmica. Já Casseb-Galvão (2004) identificou a construção $d i z$ que ${ }^{143}$, em que o verbo pleno diz, ao aparecer junto a

\footnotetext{
${ }^{140}$ Segundo Aikhenvald (2004:1), cerca de um quarto das línguas do mundo apresentam evidencialidade gramatical, ou seja, têm a seu dispor elementos gramaticais como afixos, clíticos ou partículas que sinalizam evidencialidade. O português, entretanto, não está entre elas.

141 Entedemos modalização aqui como o fenômeno pelo qual o sujeito expressa sua adesão ao texto. Através dela, é possível perceber qual a atitude do locutor na defesa do que pretende. Percebemos, assim, se ele crê no que diz, se atenua ou impõe algo que diz.

${ }^{142}$ É o que podemos perceber nestes exemplos identificados pelo autor: (1) Fica uma delícia (est) Fica uma delícia ... que (inint) Não fica aquele -fica cajuzinho cre/ caramelo, [amendoim] fica parecendo um caramelo. (PEUUCEN/E39); (2) hoje pode-se fazer o [casamento] religioso com efeitos civis e tal... então mas no/ [nós nos casamos no civil... parece que de manhã ... assim por volta de ... dez e meia onze horas por aí. (NURC/RJ/SET/71) (apud GONÇALVES, 2003: 96). Enquanto em (1), o verbo parecer funciona como predicado verbal, em (2), de acordo com a classificação de Gonçalves, ele assume a funcionalidade de quase-satélite atitudinal, codificando modalidade epistêmica/evidencialidade e, segundo o autor, contribuindo para a "promoção da diluição da responsabilidade do falante com relação ao conteúdo proposicional presente em seu enunciado" (GONÇALVES, 2003:97).

143 Observemos os seguintes exemplos apresentados pela autora: (1) (...) o deputado federal José Santana de Vasconcelos (PFL) prega uma grande aliança em torno do governador. Ele diz que o bom relacionamento entre o PFL, o PSDB e o PTB mineiros deve ser estendido ao plano federal. (EM-LJ); (2)
} 
que, assume diferentes funcionalidades a depender do contexto. Ambos os autores tratam do processo no qual se une a conjunção que a um verbo pleno e tem-se a formação de uma construção de caráter mais abstrato e de um estatuto gramatical maior do que o anterior, isto é, mais gramaticalizada. A codificação sintática dessas categorias correlacionadas ao plano da modalidade epistêmica permitem aproximar formalmente parece que; diz que e quase que. Talvez não seja apenas uma coincidência formal, mas uma estratégia comum para um problema similar.

\section{Recuando no tempo: cartas do século XIX}

As cartas do século XIX, que compõem o corpus do Projeto História do Português do Brasil (PHPB), tiveram as ocorrências das construções em questão extraídas para análise. São cartas escritas por redatores, provenientes de Críticas, queixumes e bajulações na Imprensa Brasileira do séc. XIX: cartas de leitores e cartas de redatores, de Barbosa \& Lopes (2004). De um total de 174 cartas, identificamos 4 ocorrências de quasi, como era grafado o item à época. Nas cartas escritas por leitores, oriundas de Críticas, queixumes e bajulações na Imprensa Brasileira do séc. XIX: cartas de leitores. (idem, 2006), identificamos 13 ocorrências do item em um total de 62 cartas. Juntando esses documentos, resulta uma amostra de 236 cartas, das quais 17 ocorrências foram identificadas. Vejamos alguns exemplos desses usos ${ }^{144}$ :

(18) (...) fomos obrigados a retardar a edição da folha em virtude dos ultimos desses telegrammas serem recebidos quasi às tres horas. (Carta de Redator, 1900)

(19) Apenas chegou-nos à noticia o funesto acontecimento praticado n'esta Cidade em a noite de 11 do corrente, quasi succumbimos pelo excesso do pezar (...) (Carta de Redator, 1827)

L1 (...) e assim:: morreu um colosso de gente aqui em São Paulo nessa ocasião que foi .. L2 diz que em Jundiaí também enterravam ...agora (dá um) (...) em ( ) Campinas foi menos (NURC/SP,D2, INQ.396) (apud CASSEB-GALVÃO, 2004:164). Em (1), o que temos, como afirma a autora, é uma predicação matriz - (ele) diz que - organizada a partir de um predicado, item lexical, verbo pleno (dizer) e que exige uma oração encaixada. Já em (2), temos a sinalização de um fenômeno de mudança linguística: diz, e que formam, juntos, uma construção de caráter mais abstrato e codificam modalidade epistêmica/evidencialidade, uma vez que fazem referência à fonte do conhecimento enunciado ao mesmo tempo em que especificam o tipo e o grau de comprometimento do falante - possibilidade e fraco, respectivamente.

${ }^{144}$ Os dados são apresentados de forma completa posteriormente, na descrição dos padrões funcionais de quase. 
(20) Alli veria o Senhor Popoia, que nos conformamos com quasi todas as suas opiniões divergindo comtudo em algumas (...) (Carta de Redator, 1827)

(21) Este artigo tem sido traduzido destacado em quasi todas as lingoas da Europa (...) (Carta de Redator, 1830)

Podendo ser classificado como advérbio nos casos acima, quasi aparece codificando um valor aproximativo. Quanto às funções, à exceção de "quase succumbimos", parecem-nos mais concretas, indicando, respectivamente, localização temporal e quantidade, ambas não exatas. Em quasi sucumbimos, no entanto, o conceito por trás do emprego do item é outro: o de iminência. Devido ao grande pesar, provocado por um acontecimento trágico, o redator escreve por si e por outros quando afirma terem "quase sucumbido". O emprego da expressão como um todo parece intencionar que seja demonstrada aos leitores a comoção causada pela tomada de conhecimento a respeito do ocorrido. Ao escrever quasi sucumbimos, o redator se mostra hiperbólico, intencionando que seja transmitida a ideia de que foi grande a comoção frente ao trágico acontecimento.

Essa mesma lógica de aproximação traduz-se em construções semânticas. Focalizando o escopo, verificamos que também não é categórico o campo de uso. O item pode atingir a expressão locativa, a indefinitude, a expressão temporal, a ação verbal, a prototipicidade nominal, a projeção avaliativa e a circunstância modal. Em um caso, contudo, seu escopo é anteposto. Via de regra, quase antecede seu escopo.

(22) (...) po- | rém da rua da Esperança quasi defronte | á casa do Conego Leão (...) (Carta de Leitor,1828)

(23) Manduca, comadre, é muito bãozinho; tem inclina- | ção p'ra quasi tudo, menos p'ra soldado (... ) (Carta de Leitor, seção "a pedido", 1865)

(24) Lia-se o enthusiasmo e alegria em todos os rostos. \|| Erão quasi todos paulistas (...) (Carta de Leitor, seção "comunicados", 1865)

(25) (...) era um | navio sobre as ondas de um mar batido por um tempo- | ral desfeito: quasi todos procurarão segurança no fun- | do dos carros (...) (Carta de Leitor, seção “comunicados", 1865) 
(26) (...) é a hora | do almoço, já se sabe, coisa fina, carne quasi sempre de | boi pesteado (Carta de Leitor, seção "a pedido", 1864)

(27) vi que o pêso das aguas, que | não respeita grandes barreiras, quanto | mais ás fracas havia aberto o seu antigo | caminho, interrompendo quasi a communi- | cação por aquelle lado (Carta de Leitor, seção "correspondência", 1828)

(28) Dantes quatro vintens de feijão era quasi um balaio, | agora é um fiapinho que nem os olhos enxergam. (Carta de Leitor, seção "a pedido", 1865)

(29) Uma nuvem de pó e fumo levantou-se aos ares nar- | rando a mil olhos que de varios pontos da cidade acom- | panhavão os carros uma desgraça quasi certa! (Carta de Leitor, seção “comunicados”, 1865)

(30) E demais um mercado no centro da cidade é I muito mais conveniente do que collocado quasi que em um arrebaldo, e precisando para lá ir-se | descer e subir ladeira. (Carta de Leitor, seção "secção livre", 1887)

Assim, apresentando um caráter mais concreto, o item é empregado em quasi defronte á casa, relacionando-se ao meio físico espacial. O escopo do item, nesta passagem, é defronte, que ganha imprecisão com o emprego de quasi. Parece-nos ser um uso derivado do citado em (23), pois, apesar de não significar "a maioria", carrega a ideia de que "a maioria dos traços de significação de defronte" são mantidos, mas há alguns que não. O uso codificador de um significado que se aproxima de uma totalidade e parece-nos mais quantitativo (quasi tudo; quasi todos) é o mais frequente neste conjunto de cartas. Nestes casos, quasi toma como escopo um pronome com ideia de quantidade indefinida.

Dotado de um caráter um pouco mais abstrato e tendo o tempo como escopo, quasi acompanha sempre em (26). Sempre, além de representar um tempo indefinido, possui uma acepção de temporalidade não quantificável. O item quasi quebra esse valor e adiciona uma exceção ao tempo. Parece-nos derivar da quantidade de coisas contáveis, assumindo, neste caso, um caráter não quantificável.

Em (27), o escopo é anteposto, diferente dos demais. O acontecimento designado, aqui, é a quase interrupção da comunicação, estando quasi remetendo, portanto, ao verbo interrompendo. Como acontece na maioria dos dados identificados, quasi assume a função de advérbio. $\mathrm{O}$ fato de ter sido empregado, neste caso, em posição posposta, parece-nos revelar a intenção de não dar relevância a uma possível 
circunstância que impediria a comunicação. Ao colocar-se mais à direita, impede-se que a polaridade tire um pouco da validade de "interromper". O sentido que se tem é o seguinte: algo poderia ter interrompido, mas não ocorreu de fato.

Nos exemplos (28) e (29), percebemos uma codificação semelhante, já também apresentada nas cartas de redatores. Aqueles que escrevem nos parecem assumir uma atitude hiperbólica. Em (28), ao afirmar que antes quatro vinténs de feijão era quasi um balaio $^{145}$, o efeito permite criar um intenso contraste com fiapinho que nem os olhos enxergam, tornando, assim, bastante evidente a grande desvalorização que os quatro vinténs teriam sofrido. Segundo o escrevente, anteriormente, quatro vinténs permitiriam comprar um balaio praticamente cheio de feijão, entretanto, no momento de sua enunciação essa realidade seria diferente. Quasi um balaio, assim como um balaio de, seria, portanto, locução quantificadora. No exemplo (29), o escrevente narra um acontecimento que conturbou a cidade e, estando bastante preocupado com o fato, afirma que uma desgraça quasi certa aconteceria. O tom emotivo é muito claro neste caso - note-se que a afirmação vem ainda seguida de um ponto de exclamação - o que contribui para a promoção, por parte do escrevente, de certo exagero em sua narração. A solução para não se comprometer com tal exagero é justamente o emprego de quasi.

Muito interessante é o exemplo (30), em que quasi parece sinalizar a avaliação do escrevente a respeito do local onde o mercado da cidade estaria localizado. É possível que este estivesse realmente situado próximo à periferia, entretanto, pode-se imaginar que, ao optar pelo emprego de arrebaldo ${ }^{146}$, o escrevente demonstrasse o quão mal localizado estaria, em seu ponto de vista, o mercado.

É curioso notar como, já no século XIX, quasi codificava intenções. Quando não era empregado de modo mais concreto, o item sinalizava subjetividade. Tratava-se de avaliações próprias dos escreventes, como em uma desgraça quasi certa; quasi succumbimos; quasi um balaio, quasi que em um arrebaldo. Desse modo, o item passa a pertencer ao domínio discursivo-pragmático, codificando uma informação pertinente ao interactante e não à informação em si. Parece-nos consistir em uma valoração imposta pela subjetividade do escrevente.

\footnotetext{
${ }^{145}$ De origem imprecisa, a palavra "balaio" designaria um cesto de palha, geralmente bastante grande. < http://www.dicionarioweb.com.br/pugillo.html>

146 "Arrebaldo" ou "arrebalde" seria a "parte de uma cidade situada na sua periferia". <http://www.dicio.com.br/arrabalde>.
} 


\section{Redações vestibulares: um modo abstrato e uma fase de transição}

Analisar as redações é a melhor forma de alcançar usos que não são totalmente consolidados, mas podem não se destacar ou ser marcados pelos leitores. Também pressupõe a possibilidade de alcançar nichos sociais de oralidade que equivocadamente figuram na escrita formal. De todo modo, é um espaço de reflexão interessante para verificar em que medida padrões tradicionais repisam seus caminhos e em que medida traços resilientes continuam se manifestando, reforçando as inovações de usuários de momentos anteriores.

Por defendermos, em consonância com Furtado da Cunha, Costa e Cezario (2003:34), que "a língua não é um mapeamento arbitrário de ideias para enunciados: razões estritamente humanas de importância e complexidade refletem-se nos traços estruturais das línguas", podemos dizer que há uma relação motivada entre expressão e conteúdo e que a língua pode refletir, de alguma forma, a estrutura da experiência. O locus de observação e análise dessas codificações é mesmo a construção linguística, que permite que a partir de seu uso recuperemos as propriedades da conceitualização humana do mundo ou as propriedades da mente humana ${ }^{147}$. Aqui, optamos por fazer esse rastreamento via estudo dos usos dos itens quase e quase que.

Saber, inicialmente, a diferença entre elas em termos de complexidade linguística nos conduzirá aos passos seguintes de análise. Um princípio geral nos guia nessa busca, a iconicidade, que se desdobra nos subprincípios da quantidade e da distância, e a orientação nesses casos é a seguinte: quanto maior e mais relevante for a quantidade de informação a ser transmitida ao interlocutor, maior será a quantidade de forma a ser utilizada na codificação morfossintática dessa informação, ou seja, a complexidade do pensamento tende a refletir-se na complexidade de expressão; e quanto mais distantes as informações estiverem cognitivamente, mais distantes serão também colocadas sintaticamente. Desse modo, aquilo que é mais simples e esperado

\footnotetext{
${ }^{147}$ A opção pelo uso de uma construção em detrimento de outra jamais seria, portanto, arbitrária ou desprovida de significação. E o mesmo ocorre com as consequências dessa escolha, como defende Langacker (1990:10), que endossamos: "There is also a growing realization that differences in grammatical behavior correlate with differences in meaning, and that semantic (or at least "pragmatic") consequences follow from the choice among alternative construction." Há também uma crescente percepção de que diferenças no comportamento gramatical se correlacionam com diferenças no significado, e que consequências semânticas (ou, pelo menos, "pragmáticas") se seguem a partir da escolha entre construções alternativas. (tradução sugerida)
} 
expressa-se com o mecanismo morfológico e gramatical menos complexo, ou seja, exige menos codificação. Quanto mais imprevisível se torna a informação, mais codificação ela recebe.

Dentre as 758 redações analisadas (381 bem pontuadas e 377 mal pontuadas), identificamos 23 ocorrências do item quase e 9 da locução quase que. Embora sejam pouco empregados pelos candidatos ao vestibular, plenamente justificado pela construção da assertividade requerida nessas provas, verificamos que quase, mais simples e dotada de menos forma quanto à complexidade estrutural, é mais frequente e menos marcada pragmaticamente, sendo empregada em contextos mais diversos, atribuindo um valor aproximativo a substantivos, adjetivos, pronomes e advérbios, como podemos observar nos dados abaixo listados:

(31) (...) vide a crise do "Código Florestal Brasileiro" e a quase falência do "Protocolo de Kyoto" (...) (FUVEST, Redações dissertativas, 2011)

(32) Enquanto Hobesbaum se debruça sobre o tempo passado, Heberto Linhares tem do tempo uma visão imediatista, quase infantil: o tempo é hoje, o momento é já. (FUVEST, Redações dissertativas, 2004)

(33) Percebe-se nos dias de hoje uma alta tecnologia de serviços na área de comunicação, voltada para fazermos quase tudo de dentro de nossas próprias residências (...) (FUVEST, Redações dissertativas, 2007)

(34) Fotos e vídeos pessoais podem ser disponibilizados contra a vontade de seus donos, quase não há respeito aos direitos autorais (...) (FUVEST, Redações dissertativas, 2008)

Nos exemplos (31), (32) e (33), percebemos como quase rompe com a polaridade positiva de um elemento ou estado, comportando-se como um aproximativo à totalidade de um conceito e ao grau de uma qualidade. Já em (34), rompe com a polaridade negativa da expressão não há.

A locução quase que, por sua vez, morfologicamente mais complexa porque dotada de mais forma, logo de maior exigência cognitiva para sua compreensão, mostrou-se menos frequente e mais marcada pragmaticamente, apresentando um 
contexto de uso bem menos diverso, tendo advérbios modalizadores como escopo em quase todas as ocorrências identificadas. A seguir, dados coletados:

(35) Um país marcado por um processo colonial explorador e cujo domínio político foi reservado quase que exclusivamente a uma elite econômica (...) (FUVEST, Redações dissertativas, 2003)

(36) (...) os ensinamentos bíblicos permaneceram intactos, tornando-os quase que totalmente inadequados à realidade atual. (FUVEST, Redações dissertativas, 2010)

A percepção de que o princípio da iconicidade e de seu subprincípio da quantidade - acima explanados - agem sobre os dados produzidos pelos candidatos ao vestibular em suas dissertações conduz à ideia de que a opção pelo emprego da construção quase que em detrimento de sua concorrente - quase - manifestaria a atitude do candidato de preocupar-se em transmitir conceitos e informações que sejam relevantes, mais complexos, visando ao desenvolvimento de uma dissertação criativa e, portanto, com chances de ser melhor pontuada pela banca examinadora ${ }^{148}$. De fato, foi curioso observar que quase que ocorre entre as redações consideradas como melhores em seus respectivos anos.

O confronto entre as ocorrências de quase e quase que parece estar em sintonia com o princípio de marcação (GIVÓN, 1995), segundo o qual as categorias marcadas seriam de maior complexidade estrutural, menor frequência de uso e de maior complexidade cognitiva.

A construção marcada quase que, fortemente associada ao valor discursivopragmático, constrói num modelo formal de locução conjuntiva, um modelo altamente frequente $X$-que, um simulacro de uma leveza inexistente em seu conteúdo.

\subsection{Contexto de emprego das construções nas redações vestibulares}

Uma das perguntas que elaboramos durante as discussões sobre o estatuto das construções analisadas foi justamente seu contexto preferencial ou típico. Como

\footnotetext{
${ }^{148}$ No ANEXO II, podemos observar os critérios estabelecidos para correção das redações do vestibular da Fuvest.
} 
resposta a essa questão, observamos em que parte das redações vestibulares essas construções são empregadas, procurando avaliar, ainda, se haveria paralelo entre os anos de produção e os textos que receberam as piores (tabela 1) e as melhores (tabela 2) pontuações.

Segmentamos os textos de modo a respeitar as clássicas partes de uma dissertação: introdução (contendo a tese a ser defendida), desenvolvimento (contendo a argumentação que dá sustentação à tese) e a conclusão (em que se retomam os mais fortes argumentos e/ou se conduz o raciocínio para a solução do problema). Quanto à localização geográfica no texto: consideramos como introdução o primeiro parágrafo; como desenvolvimento, os parágrafos entre o segundo e o penúltimo; e como conclusão, o último parágrafo $^{149}$.

De acordo com manuais de redação para vestibulares, a introdução da dissertação deve apresentar o tema a ser abordado e contextualizá-lo, o desenvolvimento deve conter a argumentação, e a conclusão, uma síntese do ponto de vista defendido ao longo do texto, além de possíveis soluções para a questão proposta. Ao analisarmos as redações, percebemos que nem sempre as delimitações entre as partes do texto são respeitadas pelos candidatos. Naturalmente, levamos este dado em consideração ao realizarmos a análise das tabelas a seguir.

\begin{tabular}{|c|c|c|c|}
\hline ANO & INTRODUÇÃO & DESENVOLVIMENTO & CONCLUSÃO \\
\hline 2004 & $\begin{array}{c}1 \\
\text { (quase) }\end{array}$ & $\begin{array}{c}2 \\
\text { (quase) }\end{array}$ & 0 \\
\hline 2005 & $\begin{array}{c}1 \\
\text { (quase que) }\end{array}$ & 0 & 0 \\
\hline 2006 & 0 & 0 & 0 \\
\hline 2007 & 0 & $\begin{array}{c}3 \\
\text { (quase) }\end{array}$ & 0 \\
\hline 2008 & 0 & $\begin{array}{c}2 \\
\text { (quase) }\end{array}$ & 0 \\
\hline 2009 & $\begin{array}{c}1 \\
\text { (quase) }\end{array}$ & $\begin{array}{c}1 \\
\text { (quase) }\end{array}$ & 0 \\
\hline 2010 & $\begin{array}{c}2 \\
\text { (quase) }\end{array}$ & $\begin{array}{c}3 \\
\text { (quase) } \\
1 \\
\text { (quase que) }\end{array}$ & 0 \\
\hline 2011 & 0 & 0 & 0 \\
\hline
\end{tabular}

${ }^{149}$ Corremos o risco de associar localização no texto com a respectiva intenção dissertativa do candidato em redações com piores pontuações, no entanto, de posse da correlação quantitativa, sempre será possível recuar ao texto original para verificação. 


\section{Tabela I: CONJUNTO DAS REDAÇÕES CONSIDERADAS PIORES EM CADA}

ANO

Quanto à localização exata do uso nos textos, verificamos que, em 2004, houve 3 ocorrências de quase, sendo uma no primeiro parágrafo de uma redação. Localização similar, ou seja, inicial, ocorreu também em 2009, porém com efeito diverso. Ao empregar esse item na formulação da tese, espera-se que o candidato busque preservar seu espaço e se proteger de uma sempre possível refutação. O efeito é que sua tese se torne mais suave, com uma informação menos categórica, o que evita a refutação do interlocutor. Essa é uma estratégia de modalização que garante a sobrevivência da ideia como tese. Analisemos os exemplos identificados:

(35) Vivemos num mundo dinâmico, onde as tecnologias de QUASE todos os setores da sociedade, se renovam constantemente numa velocidade cada vez maior, tornando o tempo o maior inimigo da tecnologia. (FUVEST, Redações dissertativas, 2004, introdução)

(36) O mundo em que vivemos existe inúmeras fronteiras, seja entre países, regiões, estado ou até mesmo em pensamento e psicológico, em fim em QUASE todos os cantos tem sempre uma fronteira. (FUVEST, Redações dissertativas, 2009, introdução)

Embora adotem estratégia similar, os efeitos são irremediavelmente diferentes. Na redação de 2009, o candidato parte do tema geral que consistia na apresentação da concepção de "fronteira", mas, por não ter background adequado, movimenta-se entre as informações contidas nos textos de apoio, provocando um efeito dissociativo de sua competência. Parece não ter entendido o que deveria fazer e, se isso aconteceu, parece não ter informações disponíveis para mobilizar a seu favor. A estratégia ainda é modalizadora, mas não de uma posição assumida e, sim, de uma opinião. Esse efeito fragilizou sua tese. Em (35), a estratégia volta-se ao não comprometimento com o que seria uma afirmação categórica ("a tecnologia de todos os setores").

Quase também aparece como estratégia modalizadora na argumentação. Analisemos os seguintes exemplos:

(37) (...) como foi o caso do Império Romano, que conquistou QUASE toda a Europa, espalhando sua cultura (Elenismo) quando conquistou a Grécia (FUVEST, Redações dissertativas, 2004, desenvolvimento) 
(38) (...) o mesmo índio que QUASE não participa da nossa história. (FUVEST, Redações dissertativas, 2004, desenvolvimento)

(39) (...) travam guerras por QUASE tudo, pelo poder, por territórios, pelo simples prazer de destruir (...) (FUVEST, Redações dissertativas, 2007, desenvolvimento)

(40) (...) os objetivos viram sonhos que de sua própria natureza carrega o peso de ser QUASE impossível. (FUVEST, Redações dissertativas, 2007, desenvolvimento)

(41) Percebe-se nos dias de hoje uma alta tecnologia de serviços na área de comunicação, voltada para fazermos QUASE tudo de dentro de nossas próprias residências (...) (FUVEST, Redações dissertativas, 2007, desenvolvimento)

(42) (...) construir bibliotecas as pessoas QUASE não tem apoio dos colegas da família (...) (FUVEST, Redações dissertativas, 2008, desenvolvimento)

(43) Pela Internet a pessoa pode fazer QUASE tudo, administrar o seu dinheiro, conversar com os amigos (...) (FUVEST, Redações dissertativas, 2008, desenvolvimento)

(44) (...) mas tão ocupação causou uma paralização QUASE geral das aulas em torno do campus. (FUVEST, Redações dissertativas, 2010, desenvolvimento)

(45) (...) e QUASE não saem de casa, como se dependessem das informações e histórias transmitidas para sobreviver. (FUVEST, Redações dissertativas, 2010, desenvolvimento)

(46) Mas, na realidade o que vemos é uma divisão gigantesca de classes, onde é QUASE impossível avaliar as pessoas por seus valores morais (...) (FUVEST, Redações dissertativas, 2010, desenvolvimento)

Essas ocorrências estão localizadas na argumentação do texto e se referem a estratégias de modalização, cujos efeitos são de rompimento com um valor categórico expresso: tudo, toda, impossível e geral. Essa estratégia permite deslocar o candidato para uma posição de conforto, pois dificilmente poderá ser punido por ter assumido uma posição cuidadosa ao manipular informações totalmente plausíveis. Quase integra, assim, trechos argumentativos com uma mensagem clara ao interlocutor: não haverá como refutar minha ideia, pois não assumi posicionamento categórico. E essa estratégia salva os candidatos de serem punidos por inconsistência argumentativa. Nos três únicos casos em que não há valores absolutos empregados, verificamos estratégias de polaridade negativa justapostas: quase não tem apoio, quase não participa e quase não saem, sendo que o escopo de quase recai sobre o advérbio de negação, minimizando seu 
efeito categórico de inexistência da ação. Trata-se de estratégia mais complexa que as demais, pois exige maior esforço cognitivo, como verificaremos em análise posterior.

A construção quase que aparece muito pouco nas redações, o que já supúnhamos. Mas não equivalem, quando empregadas, aos mesmos efeitos discursivos. Identificamos casos dessa construção na introdução e também na argumentação do texto. Analisemos os seguintes casos:

(47) Os meios de comunicação como televisão, rádio, internet, etc. são muito importantes nos dias de hoje, pois possibilitam uma troca de informações em uma velocidade, e com uma facilidade incríveis. Uma tragédia na Ásia, por exemplo, é noticiada QUASE QUE em tempo real para o mundo todo. (FUVEST, Redações dissertativas, 2005, introdução)

(48) (...) os ensinamentos bíblicos permaneceram intactos, tornando-os QUASE QUE totalmente inadequados à realidade atual. (FUVEST, Redações dissertativas, 2010, desenvolvimento)

$\mathrm{Na}$ apresentação da tese, quase que vem expresso dentro da parte ilustrativa, em que o candidato expõe elementos de seu background. Adicionalmente, expressa sua posição assumida ao intensificar a ideia de velocidade, pois quase que atua para minimizar a distância temporal referida pelo escrevente. Estratégia acertada para o efeito pretendido. Diversamente, o texto produzido em 2010 inclui uma estratégia modalizadora de uma avaliação apresentada, como a proteger-se de críticas previstas para o argumento forte que apresenta. Esta última estratégia, de modalização, é muito mais próxima ao que temos visto nos usos do item quase.

Dois casos nos chamaram atenção e foram produzidos por candidatos de 2010. Ambos empregam quase na introdução e têm suas redações avaliadas como ruins. Numa análise mais detida, verificamos que ambos os candidatos fogem ao tema proposto - construção de imagens e o emprego dessas na substituição do real imediato e são punidos por isso. Notemos, portanto, que essa punição não tem qualquer relação com a estratégia modalizadora empregada.

(49) USP, quem nunca ouviu esse nome? Uma das mais conceituadas instituições de ensino do Brasil e do mundo, onde o ensino é passado plenamente, com exemplar organização, excelente infra-estrutura por profissionais QUASE perfeitos. Somente quem não acompanha tal instituição poderia acreditar em tais afirmações. (FUVEST, Redações dissertativas, 2010, introdução - Fuga ao Tema) 
(50) Muitos casos são sempre muito comentados sobre as grandes instituições de ensino, como vandalismo e violência, mas em QUASE todos quem realmente deveria receber a culpa e a punição sai livre de qualquer acusação e apenas as instituições tem que arcar com os prejuízos e a má reputação. (FUVEST, Redações dissertativas, 2010, introdução - Fuga ao Tema)

Considerando tão somente os resultados numéricos derivados da quantificação desses casos, demonstrados na tabela anterior, notamos que, dentre as redações de pior pontuação, de um total de 15 ocorrências de quase, apenas uma não foi empregada em contexto de argumentação, tendo sido utilizada para introduzir o tema proposto. Nenhum candidato, no entanto, emprega esses itens para construir as conclusões de seus textos.

Considerando o conjunto das amostragens de redações dissertativas (200 provas por ano) e o tempo correspondente de oito anos (8 provas vestibulares), seria possível intuir que quase e quase que são pouco empregados. Mas também seria possível hipotetizar que esses empregos são exclusivos de redações consideradas piores. Se a intuição é validada pelas ocorrências nas melhores redações, a hipótese se mostra totalmente infundada. Analisemos detidamente a distribuição das ocorrências entre as redações com melhor pontuação.

\begin{tabular}{|c|c|c|c|}
\hline ANO & INTRODUÇÃO & DESENVOLVIMENTO & CONCLUSÃO \\
\hline 2003 & $\begin{array}{c}1 \\
\text { (quase que) }\end{array}$ & $\begin{array}{c}1 \\
\text { (quase que) }\end{array}$ & 0 \\
\hline 2004 & 0 & $\begin{array}{c}4 \\
\text { (quase) }\end{array}$ & $\begin{array}{c}1 \\
\text { (quase) }\end{array}$ \\
\hline 2005 & 0 & $\begin{array}{c}2 \\
\text { (quase) }\end{array}$ & 0 \\
\hline 2006 & 0 & 0 & 0 \\
\hline 2007 & 0 & 0 & 0 \\
\hline 2008 & 0 & $\begin{array}{c}2 \\
\text { (quase) }\end{array}$ & 0 \\
\hline 2009 & 0 & 0 & 0 \\
\hline 2010 & $\begin{array}{c}1 \\
\text { (quase que) }\end{array}$ & 0 & 0 \\
\hline 2011 & 0 & $\begin{array}{c}2 \\
\text { (quase) } \\
1 \\
\text { (quase que) }\end{array}$ & 0 \\
\hline
\end{tabular}

CADA ANO 
Entre as redações mais bem pontuadas pela banca examinadora da Fuvest, não houve ocorrência de quase e quase que nos anos de 2006, 2007 e 2009. É importante ressaltar, entretanto, que a construção inovadora quase que apresenta um maior número de ocorrências neste conjunto constituído pelas redações com melhor pontuação do que naquele formado pelas de pior pontuação.

Também neste conjunto, as fronteiras entre as partes do texto (introdução, desenvolvimento e conclusão) - apesar de melhor definidas do que o observado nas redações consideradas piores - não foram totalmente respeitadas ${ }^{150}$. Verificamos, portanto, o emprego de quase que na introdução de um texto de 2003 que, porém, já iniciava a argumentação. A proposta de redação desse ano consistia em discutir manifestações concretas de afirmação ou de negação da auto-estima entre os brasileiros. Ao iniciar sua dissertação com a afirmação de que "No Brasil o que temos é uma QUASE QUE completa negação da auto-estima (...)”, o candidato já assume um ponto de vista. A ocorrência no desenvolvimento de uma dissertação foi a seguinte: "Um país marcado por um processo colonial explorador e cujo domínio político foi reservado QUASE QUE exclusivamente a uma elite econômica (...)".

O mesmo ocorre com o uso de quase que na introdução de um texto de 2010. A proposta de redação, como já citamos aqui, lidava com a construção de imagens e com o emprego dessas na substituição do real imediato. Realizando um recorte do tema, o candidato que empregou quase que tratou da constante criação de imagens que vivenciamos em nosso cotidiano através dos mais diversos meios de comunicação. Introduziu seu texto, assim, com a seguinte sentença: “A QUASE QUE onipresença dos meios de comunicação na atualidade força insistentemente o contato com a imagem.". Notamos, claramente, o início da argumentação. O emprego da construção em questão seria justificado pela polaridade positiva categórica do termo "onipresença".

Em uma dissertação de 2004, quase foi empregada na conclusão, mais precisamente na última sentença do texto: “O relógio QUASE líquido de Dalí jamais se desfará por completo, permanecendo o tempo como um conceito abstrato, impalpável, mas sempre presente na realidade concreta.”. A proposta de redação desse ano referirse-ia ao posicionamento por parte do candidato diante das diferentes concepções de

\footnotetext{
${ }^{150} \mathrm{O}$ que nos leva a questionar a necessidade de se continuar a insistir na cobrança de um texto dissertativo que siga a estrutura "fechada": apresentação do tema na introdução (primeiro parágrafo); argumentação no desenvolvimento (do segundo ao penúltimo) e retomada dos argumentos e/ou exposição de solução para o problema proposto (último parágrafo).
} 
tempo apresentadas por três diferentes autores. Ele deveria argumentar em favor da concepção com a qual mais se identificasse. $\mathrm{O}$ candidato autor da citada dissertação desenvolveu sólida argumentação e, apesar de sua conclusão cumprir adequadamente sua função, apresenta ideias que não haviam sido trabalhadas anteriormente no texto. A última sentença, apresentada acima, faria, portanto, parte de um contexto de argumentação. Os demais empregos, todos em desenvolvimento de argumentação, identificados em redações desse ano foram:

(51) Duas antíteses que combatem a tese, do presente ferrenhamente, QUASE como se fossem excludentes. (FUVEST, Redações dissertativas, 2004)

(52) Enquanto Hobesbaum se debruça sobre o tempo passado, Heberto Linhares tem do tempo uma visão imediatista, QUASE infantil: o tempo é hoje, o momento é já. (FUVEST, Redações dissertativas, 2004)

(53) É um passado que é QUASE um desvanecer. (FUVEST, Redações dissertativas, 2004)

(54) Infelizmente, QUASE nunca temos uma versão neutra e objetiva dos acontecimentos. (FUVEST, Redações dissertativas, 2004)

Os empregos em desenvolvimento de argumentação nos demais anos (2005, 2008 e 2011) foram os seguintes:

(55) Criou-se QUASE uma teoria conspiratória para basear o manifesto. (FUVEST, Redações dissertativas, 2005)

(56) Mas, além dessas catracas visíveis, existem outras. Elas são QUASE imperceptíveis, mas alcançam uma profundidade maior. (FUVEST, Redações dissertativas, 2005)

(57) Além disso, a informação (QUASE?) infinita ajuda a demolir barreiras (...) (FUVEST, Redações dissertativas, 2008)

(58) Fotos e vídeos pessoais podem ser disponibilizados contra a vontade de seus donos, QUASE não há respeito aos direitos autorais (...) (FUVEST, Redações dissertativas, 2008)

(59) (...) apesar do auxílio prestado, pouco ou QUASE nada é realizado com a finalidade de erradicar definitivamente o problema (...) (FUVEST, Redações dissertativas, 2011) 
(60) Se a unidade religiosa e cultural, antes, resultava numa solidariedade vinculante esta se dava QUASE QUE apenas entre iguais e a um preço alto (...) (FUVEST, Redações dissertativas, 2011)

(61) (...) vide a crise do "Código Florestal Brasileiro" e a QUASE falência do Protocolo de Kyoto (FUVEST, Redações dissertativas, 2011)

Tanto quase quanto quase que foram, também entre as consideradas melhores redações de cada ano, empregadas somente em desenvolvimento de argumento. $\mathrm{O}$ caráter subjetivo assumido por essas construções em determinados contextos pareceunos, após essa análise, ainda mais evidente, pois temos não somente modalização de avaliação cujo escopo é adjetivo, nem somente choque de polaridades negativas em ações. Há, sim, escopos nominais de classe substantiva que permitem construir um espaço de reflexão altamente subjetivo, tais como: quase uma teoria e quase falência, demandando muito mais empenho cognitivo para alcançar a ideia codificada.

Pela análise desses usos, fica clara a mobilidade sintática da classe dos advérbios como algo esperado e aceito. A construção quase, entretanto, classificada como advérbio - e restou mais clara essa ideia após o cotejo que realizamos com as acepções registradas pelos dicionários ${ }^{151}$ - não apresenta essa mobilidade nos dados os quais identificamos nas amostras.

Somando os 17 dados identificados no corpus de cartas de leitores e redatores nos séculos XIX e os 32 dados analisados nas redações de vestibular da Fuvest, apenas um dado, como já vimos - presente em uma carta de leitor do século XIX - apresenta a construção quasi em posição posposta a seu escopo, no caso, o verbo "interrompendo", indicando que a interrupção esteve na iminência de acontecer:

(62) Depois de cessar por um pouco essa abundante chuva, que | desde o anno passado tem caido todos os | dias sem interrupção, quiz ver o estado da | varzea do Carmo, e se com effeito tinha- | se conseguido o fim d'esgotál-a, dirigi-me | até a chamada ponte do ferrão, que foi | entulhada, e vi que o pêso das aguas, que | não respeita grandes barreiras, quanto | mais ás fracas havia aberto o seu antigo | caminho, interrompendo QUASI a communi- | cação por aquelle lado causando um in- | commodo indisivel, não só aos habitantes $\mid$ da Cidade, como aos lavradores, que não | podem condusir seus generos; e o mais é | que ja está assim há muito tempo!!! (Carta de Leitor, seção "correspondência", 1828)

151 Bluteau (1720: 25), Lima (1946: 1029; 1951:1012), Machado (1967:1923), Ferreira (1986:1427; 1999:1167) e Houaiss \& Villar (2009:1586). Além desses, Castilho \& Elias (2012:247) e Neves (2000:254) classificam quase como advérbio, mais especificamente, de intensidade. 
Inserindo o item quasi em posição posposta ao escopo, impedindo-o de encabeçar a oração - interrompendo QUASI a communicação por aquelle lado - o escrevente proporciona destaque ao evento sinalizado pelo verbo: a interrupção da passagem pela citada ponte do ferrão. Em posição anteposta a seu escopo, o item quasi, apesar de vir a indicar uma aproximação bastante efetiva à ideia sinalizada pelo escopo, como ocorre nos demais dados, não permitiria à interrupção um destaque tão grande como aquele a ela destinado através da topicalização do verbo "interrompendo". Essa ênfase faz sentido se pensarmos no objetivo da carta: denunciar a necessidade de se providenciar consertos - os quais, segundo o escrevente, já estariam bastante atrasados - para os estragos provocados pelas fortes chuvas, que teriam causado grande incômodo aos habitantes e, principalmente, lavradores da cidade, prejudicando seus trabalhos. Enfatizar a gravidade da situação contribui, desse modo, para o objetivo principal da carta em questão.

Em todos os outros dados, quase aparece anteposto a seu escopo, o que nos conduz à conclusão de que se trata de uma construção com pouquíssima mobilidade, aspecto esse que contraria o conjunto de características prototípicas da categoria dos advérbios.

A título de ilustração, analisemos o seguinte exemplo extraído das provas da Fuvest, Redações dissertativas:

(63) Fotos e vídeos pessoais podem ser disponibilizados contra a vontade de seus donos, QUASE não há respeito aos direitos autorais e falta segurança para as máquinas dos conectados à Internet. (FUVEST, Redações dissertativas, 2008)

Nele, o item quase aparece na posição inicial na segunda oração do período e a toma inteira como escopo. Se pensarmos que diferentes padrões de codificação sintática indicam codificações de diferentes intenções na língua, podemos afirmar que a posição prototípica de quase e quase que é anteposta a seu escopo e que, se, no entanto, houver uma motivação a mais para codificar, será a ordem o fator de alteração envolvido na construção.

Em diálogo com Traugott (2010), vimos que muito do que se manifesta na codificação linguística é derivada do peso e da força da subjetificação. Assim, a tendência de se tornar cada vez mais baseado no estado de crença subjetiva ou atitude 
do falante/escritor conduziriam os itens subjetificados a ocupar posições periféricas. É óbvio que esse deslocamento também deve ser considerado em relação ao estatuto regular da língua sob análise. Em línguas que seguem a ordenação verbo-objeto, como o inglês e o português, esses elementos se deslocam para a esquerda.

Apresentando praticamente nenhuma mobilidade, como mencionamos acima, a construção quase é empregada primordialmente à esquerda de seu escopo, revelando seu aspecto subjetivo, vinculado ao estado de crença subjetiva ou atitude dos escreventes, tais como demonstramos com as intenções de modalizar.

Há um senão. Pode ser que a estratégia do descomprometimento seja ligada ao gênero discursivo, ou seja, ao tipo de texto produzido pelos candidatos tendo em vista seus objetivos comunicativos. E para verificar em que medida o observado é regra geral e não estratégia pontual ligada ao contexto de produção, constituímos uma terceira amostragem de dados: resumos de teses concluídas e defendidas na Universidade de São Paulo em áreas variadas do conhecimento.

\subsection{Amostra de controle: em busca da produção cuidadosa e revisada do uso}

Para esta empreitada, que tem como fim a verificação da validade dos resultados das análises desenvolvidas até este ponto, compusemos uma amostra de dados, a partir dos quais teremos acesso a produções de escreventes cultos e que, com certeza, tiveram o cuidado de revisar e escolher adequadamente sua fórmula mais segura de escrita. Trata-se de resumos de teses e dissertações disponíveis à consulta da comunidade acadêmico-científica on line. São textos com autoria identificada e com uma alta padronização textual. Como pressupõem revisão gramatical e redacional antes de divulgação, espera-se que usos inadequados para os padrões considerados normativos sejam elididos em alguma fase prévia à publicação.

Ao analisar os dados, verificamos que as intenções eram claramente presentes também nos resumos de teses. Analisemos o seguinte caso:

(64) A contribuição estratigráfica mais importante desta pesquisa foi a descoberta de Cloudina na Formação Guaicurus, acima da Formação Tamengo, descoberta esta que estende a biozona de Cloudina até QUASE o topo do Grupo Corumbá. (INSTITUTO DE GEOCIÊNCIAS, 2011, Resumos de teses, séc. XXI) 
Com a intenção de valorizar sua pesquisa, o autor enfatiza a amplitude da contribuição da mesma ao afirmar que a descoberta por ela reportada estende a chamada biozona de Cloudina até próximo ao topo do Grupo Corumbá, uma faixa descontínua de solo de 1400 quilômetros de comprimento na região sudoeste do Brasil ${ }^{152}$. O emprego de quase, um aproximativo impreciso, permite ao autor conferir amplitude para sua afirmação sem se comprometer. Não temos a informação da proximidade exata a qual a referida biozona estaria do topo do Grupo Corumbá. O autor, que pode ou não ter conhecimento dessa informação, prefere uma afirmação mais imprecisa, mas que impressione o leitor, leve-o a imaginar que a proximidade entre ambos os elementos é bastante grande e a valorizar a pesquisa em questão. Uma afirmação precisa, com a real distância entre os elementos, poderia não causar esse efeito. O caráter subjetivo do emprego de quase, nesse exemplo, é totalmente evidente.

(65) Além de ser previsto em lei, o tratamento da fração orgânica se faz necessário já que no Brasil são gerados QUASE 100 mil toneladas por dia de resíduos orgânicos. A maioria desses resíduos é atualmente disposta em aterros sanitários. (ESCOLA DE ENGENHARIA DE SÃO CARLOS, 2013, Resumos de teses, séc. XXI)

(66) QUASE 3 bilhões de pessoas vivem em áreas tropicais de risco de infecção com uma das 5 espécies evidenciando um problema mundial carente de solução imediata. (INSTITUTO DE BIOMÉDICAS, 2012, Resumos de teses, séc. XXI)

(67) mostrou que o OLAM v3.3 subestima a energia do sinal intrasazonal na região do oceano Índico em QUASE a metade do valor real observado. (INSTITUTO DE ASTRONOMIA, GEOFÍSICA E CIÊNCIAS ATMOSFÉRICAS, 2012, Resumos de teses, séc. XXI)

(68) O consumo excessivo de carne foi observado em QUASE 75 por cento das pessoas e o tipo de carne mais consumido nos dois períodos foi a bovina (FACULDADE DE SAÚDE PÚBLICA, 2012, Resumos de teses, séc.XXI)

(69) Tanto a análise para colágeno tipo I quanto a análise para elastina apontaram um aumento de QUASE $20 \%$ em relação às amostras não tratadas. (FACULDADE DE FILOSOFIA, LETRAS E CIÊNCIAS HUMANAS DE RIBEIRÃO PRETO, 2012, Resumos de teses, séc. XXI)

(70) A viabilidade para o período ovoadulto foi QUASE duas vezes superior à viabilidade obtida na dieta natural, sendo de $68 \%$ em relação

152 <www.sbgeo.org.br/pub_sbg/.../2303301>. Acesso em: 19/10/2013. 
aos $38 \%$ obtidos na dieta natural (ESCOLA SUPERIOR DE AGRICULTURA “LUIZ DE QUEIROZ”, 2012, Resumos de teses, séc. $\mathrm{XXI})$

(71) As práticas não saudáveis para controle do peso foram QUASE três vezes mais prevalentes e evidenciou-se que estas práticas aumentam o risco de desenvolver comportamentos mais graves. (FACULDADE DE SAÚDE PÚBLICA, 2013, Resumos de teses, séc. XXI)

O que observamos nos exemplos acima é, novamente, a intenção de causar, nos leitores, a impressão de amplitude, sem que haja, porém, comprometimento por parte do autor. A ideia é enfatizar as quantidades para, assim, dar destaque aos dados apresentados pela pesquisa. A exposição de um dado de forma imprecisa, possibilitada pelo emprego de quase, conduz o leitor a assumir como informação uma quantidade maior do que aquela a qual seria indicada pela quantificação exata, precisa.

Nos exemplos seguintes, embora sigam a mesma orientação funcional, a intenção é fazer atentar para o fato de determinados valores estarem bastante próximos a zero. Essa ideia torna-se muito mais enfática através do emprego de uma expressão como "quase nulos" do que seria com uma informação precisa. Em (72), o autor intenciona enfatizar o rápido decréscimo dos títulos vacinais, os quais após seis meses estariam próximos a zero. O emprego de quase nulos é o grande responsável pela impressão adquirida pelo leitor de que a quantidade de títulos vacinais após apenas seis meses era insignificante. Em (73), a ênfase dada ao fato de a recuperação de partículas grossas ter sido próxima a zero para condições hidrodinâmicas mais severas vem da necessidade de criar um contraponto em relação a essa recuperação em condições hidrodinâmicas pouco turbulentas, a qual teria decrescido, mas, aparentemente, não teria chegado perto de ser nula. Já em (74), o que observamos é a intenção de preservação de face $^{153}$ por parte do escrevente. Com o intuito de defender a ideia de que os danos físicos não são os únicos passíveis de acometer pessoas às quais são direcionados questionamentos em pesquisas, o autor aponta para o erro que, segundo ele, seria cometido pelos pesquisadores nesse sentido: o de pensar-se que o risco para os participantes é quase nulo. Uma vez que se encontra em posição de assumir uma premissa a respeito do modo como os pesquisadores encaram os riscos para os

\footnotetext{
${ }^{153}$ Goffman (1985:77) define face como "o valor social positivo que uma pessoa efetivamente reclama para si mesma através daquilo que os outros presumem ser a linha por ela tomada durante um contato específico."
} 
participantes de pesquisas, o escrevente sente a necessidade de preservar sua face, daí o emprego da construção quase, a qual impede que seja afirmado que, na opinião do autor, o pensamento geral entre os pesquisadores seria o de que o risco para os participantes é inexistente.

(72) Os títulos vacinais tenderam a baixar rapidamente nos meses subsequentes à vacinação, sendo QUASE nulos após seis meses das revacinações. (FACULDADE DE MEDICINA VETERINÁRIA E ZOOTECNIA, 2005, Resumos de teses, séc. XXI)

(73) Em condições hidrodinâmicas pouco turbulentas, a recuperação de partículas grossas decresce em função de falta de suspensão de partículas, por outro lado para condições hidrodinâmicas mais severas a recuperação foi QUASE nula devido à destruição do agregado partícula/bolha. (ESCOLA POLITÉCNICA, 2010, Resumos de teses, séc. XXI)

(74) A valorização dos limites éticos, no que diz respeito à abordagem às pessoas, em pesquisas em que utilizem instrumentos contendo questionamentos é pouco considerada. Pensa-se que o risco para os participantes é QUASE nulo, uma vez que a utilização de tais instrumentos não envolve danos físicos. Deste modo, parece não estar muito clara para os pesquisadores a importância da reflexão sobre estes tipos de instrumentos de coleta de dados como possíveis geradores de riscos de ordem não-física (psicológicos, morais, sociais, espirituais). (ESCOLA DE ENFERMAGEM, 2009, Resumos de teses, séc. XXI)

Considerando, neste momento, os exemplos abaixo, verificamos que a intenção sugerida é a de intensificar a quantidade de tempo decorrido, transmitir, ao leitor, a impressão de tratar-se de um amplo espaço de tempo. Em (75), o objetivo é valorizar o Movimento dos Trabalhadores Rurais Sem Terra, apontando para o que seria um longo tempo de existência - quase trinta anos - informação que contribui para a ideia de perenidade defendida pelo autor na sequência. No exemplo seguinte, o grande esforço de investigação é ainda mais valorizado quando seu período de elaboração é indicado através do emprego de quase antes do que seria um longo tempo para um trabalho de pesquisa a respeito da vida de um autor: três décadas. Em (77), a própria pesquisa a que pertence o resumo é valorizada ao ser afirmado que essa lida com fragmentos ao longo de quase um século. Mais uma vez, o emprego do aproximativo quase e a imprecisão temporal por ele causada sugerem, ao leitor, a impressão de um espaço de tempo mais longo do que o faria uma informação temporal precisa. 
(75) Desde seu nascimento, há QUASE trinta anos, o Movimento dos Trabalhadores Rurais Sem Terra (MST) tem se destacado pela perenidade de sua organização (FACULDADE DE FILOSOFIA, LETRAS E CIÊNCIAS HUMANAS, 2013, Resumos de teses, séc. XXI)

(76) Dentre os títulos dedicados à vida do escritor russo destaca-se Dostoiévski de Joseph Frank, um grande esforço de investigação elaborado ao longo de QUASE três décadas. (FACULDADE DE FILOSOFIA, LETRAS E CIÊNCIAS HUMANAS, 2013, Resumos de teses, séc. XXI)

(77) Desenhado a partir de fragmentos de QUASE um século, o caráter do estudo é em primeiro lugar de natureza histórica. (FACULDADE DE ARQUITETURA E URBANISMO, 2012, Resumos de teses, séc. XXI)

O mecanismo envolvido no emprego de quase, quando seu escopo é menos preciso quanto ao sentido, ou seja, tem valor mais genérico ou amplo, tal como vimos anteriormente com as redações, é semelhante àquele percebido nos exemplos em que o escopo é todos ou todas: seleção de elementos de um conjunto, o qual exige um recorte, uma seleção, uma restrição. A polaridade negativa de quase daria conta desse processo.

A seguir, os exemplos consistem da seleção de membros de um conjunto e recorte de uma "massa", de um todo, no caso, em (83), o período total de vida dos camundongos MDX e, em (84), o corpo inteiro do colubrídeo.

(78) Foram analisadas a proliferação, morte e ciclo celular, além da formação e diferenciação de neuroesferas, utilizando, em QUASE todas as etapas, a citometria de fluxo. (FACULDADE DE MEDICINA, 2013, Resumos de teses, séc. XXI)

(79) A anemia é considerada um dos maiores problemas de saúde pública da atualidade, afetando as populações de QUASE todos os países, sobretudo aqueles onde predominam padrões dietéticos deficientes e fatores ambientais adversos. (FACULDADE DE SAÚDE PÚBLICA, 2013, Resumos de teses, séc. XXI)

(80) A análise das informações indicou-nos que a maioria dos alunos atendidos nas Salas de recursos em 2011 era composta por aqueles com deficiência intelectual sendo que havia mais estudantes do sexo masculino $(60,52 \%)$ e que, em QUASE todos os tipos de deficiência e Transtorno global de desenvolvimento, registrou-se mais meninos 
atendidos do que meninas. (FACULDADE DE EDUCAÇÃO, 2013, Resumos de teses, séc. XXI)

(81) Já nos animais adultos, verificou-se maior semelhança ao perfil dos camundongos controles normais da mesma idade, com exceção do gene Large que apresentou expressão diminuída em QUASE todos os animais em estudo. (INSTITUTO DE BIOCIÊNCIAS , 2013, Resumos de teses, séc. XXI)

(82) As cantigas de maldizer, os satíricos barrocos, Bocage, Camilo Pessanha, Mário de Sá-Carneiro e Al Berto representam as produções grotescas de suas épocas e participam, em QUASE todos os casos, do cânone literário português. (FACULDADE DE FILOSOFIA, LETRAS E CIÊNCIAS HUMANAS, 2013, Resumos de teses, séc. XXI)

(83) Concluímos que no plexo mioentérico esofágico de camundongos MDX existe uma redução dos neurônios mediadores do relaxamento, especialmente em animais jovens (MDX4), provavelmente porque o organismo tenta manter íntegra a função peristáltica do órgão. Esse fato pode explicar a adaptação e ausência de disfunções esofágicas durante QUASE toda a vida desses animais. (FACULDADE DE MEDICINA VETERINÁRIA E ZOOTECNIA, 2012, Resumos de teses, séc. XXI)

(84) Combate pode ocorrer durante a primavera e os machos tendem a ficar com a porção cranial do corpo na vertical durante o duelo, diferentemente da maioria dos outros colubrídeos que mantém QUASE todo o corpo na horizontal. (FACULDADE DE MEDICINA VETERINÁRIA E ZOOTECNIA, 2012, Resumos de teses, séc. $\mathrm{XXI})$

O emprego de quase, no próximo exemplo, apesar dos diferentes escopos $-a$ totalidade; todas - remete a um mesmo mecanismo: aproximação a um conjunto de elementos e seleção do que seria a maioria desses. No primeiro caso, "a totalidade dos familiares" indica o conjunto do qual o emprego de quase seleciona elementos, em seguida, esse conjunto seria sinalizado pela palavra todas - referente às pessoas que foram entrevistadas e, no último caso desse trecho, "a totalidade das justificativas". Percebemos que a imprecisão é constante no trecho. O escrevente opta por promover aproximações a totalidades em detrimento da apresentação de contabilizações precisas. Mesmo quando não emprega quase, ele recorre à aproximação, como observamos em acima de 90\%. A intenção em todos esses contextos parece ser a mesma: causar a impressão ao leitor de que os resultados encontrados correspondem à maior parte dos 
elementos constituintes de cada conjunto: a totalidade dos familiares; a totalidade das pessoas; a totalidade das justificativas.

(85) QUASE a totalidade dos familiares afirmou que a chegada da criança foi bem aceita pela família, e a maioria considerou importante incluir essa questão na consulta de saúde da criança. Quanto aos aspectos afetivos, $90 \%$ das respostas foram positivas em relação às questões do instrumento, sendo este o considerado mais importante na consulta de puericultura para $90,6 \%$ dos respondentes, $94,8 \%$ consideraram importante a realização cuidados de higiene diária, acima de $90 \%$ afirmaram que também consideram importante a inclusão desse tema na consulta, e acima de $90 \%$ afirmaram que também consideram importante a inclusão desse tema na consulta, e QUASE todas reconhecem como importante para a criança ter um bom acompanhamento de saúde. (...) QUASE a totalidade das justificativas apontam para o entendimento pelo profissional como elemento norteador da conduta para o bom cuidado da criança. Conclusão: a maioria dos familiares realiza o cuidado, mesmo que alguns deles não sejam compreendidos como fundamentais para o desenvolvimento infantil. (ESCOLA DE ENFERMAGEM, 2012, Resumos de teses, séc. XXI)

Nos próximos casos, também com ocorrência nas cartas de leitor do século XIX, como já apresentamos, o advérbio sempre é tomado como escopo. As intenções comunicativas aqui, entretanto, parecem ser bastante diversas. Em (87), a construção quase precisou ser empregada em virtude da informação que a sucederia: às vezes tem sobrecarga de trabalho, ou seja, às vezes não há disponibilidade suficiente de profissionais. A construção, promovendo uma aproximação a sempre, sinaliza, entretanto, que, na maioria das vezes, isto é, o que ocorre com mais frequência, é uma disponibilidade suficiente de profissionais. Já em (88), a intenção parece estar mais voltada à ideia de uniformização. Ao descrever os problemas identificados durante a fase de análise da pesquisa, o autor recorre à aproximação a generalizações como forma de evidenciar a gravidade dos problemas apontados. A efetiva generalização não poderia ser realizada pelo escrevente, nem todos os casos de demanda em saúde mental por ele analisados eram acompanhados de angústia por parte dos profissionais, nem todos se sentiam incapazes de atender usuários com essa demanda de saúde, assim como os profissionais nem sempre se limitavam apenas a executar prescrições médicas. Uma vez que os dados levantados não permitem ao pesquisador afirmações categóricas, generalizadas, o recurso por esse criado foi o de promover aproximações, através da 
utilização de quase, ao que estaria se referindo à totalidade dos casos analisados, evidenciando, assim, a gravidade dos problemas identificados.

(86) Vale ressaltar que a aproximação do campo de tensões, dada por estas formulações não convencionais, pode permitir melhor estimativa da danificação da estrutura, frente ao MEF convencional. Isto se dá porque os critérios de danificação empregados são QUASE sempre baseados na estimativa do campo de tensões atuantes. (ESCOLA DE ENGENHARIA DE SÃO CARLOS, 2013, Resumos de teses, séc.XXI)

(87) QUASE sempre há disponibilidade suficiente de profissionais; às vezes tem sobrecarga de trabalho. (ESCOLA DE ENFERMAGEM, 2013, Resumos de teses, séc.XXI)

(88) A partir da análise pudemos entender que a demanda em saúde mental é constante no serviço e que essa vem, QUASE sempre, acompanhada de uma angústia por parte dos profissionais que não se sentem capazes de atender usuários com essa demanda de saúde. Através da observação e da entrevista constatou-se ainda que, no serviço, o modelo de atendimento é ainda o médico-centrado, sendo que os demais profissionais da equipe, QUASE sempre, se limitam apenas executar prescrições médicas como, por exemplo, medicação e, quando necessário, contenção. (ESCOLA DE ENFERMAGEM, 2012, Resumos de teses, séc.XXI)

A lógica do que vínhamos verificando com as redações ou mesmo com as cartas do século XIX se mantêm nos resumos de tese. Nos exemplos seguintes, podemos admitir que possuímos duas palavras dotadas de valor categórico: total - devido à sua polaridade altamente positiva - e ausência. As afirmações "uma ausência de material conchífero" e "uma ausência total de material conchífero" possuem o mesmo significado, diferindo-se apenas no que se refere à ênfase dessa ausência, que se torna maior quando acompanhada pelo adjetivo total. O mesmo ocorre com o outro exemplo. Os autores intencionavam, portanto, enfatizar a ausência, a qual, entretanto, não era real, tornando-se necessário o emprego da construção quase, cuja polaridade negativa e caráter aproximativo permitiram que fosse sinalizada a ideia de que a ausência não era efetiva, mas que havia chegado próximo de o ser.

(89) Uma ausência QUASE total de material conchífero... (MUSEU DE ARQUEOLOGIA E ETNOLOGIA, 2008, Resumos de teses, séc. XXI) 
(90) No que se refere às realizações arquitetônicas e urbanísticas, a fase brasileira de Jan Bata, por sua QUASE total ausência na historiografia, ainda carece de melhor conhecimento e análise. (ESCOLA DE ENGENHARIA DE SÃO CARLOS, 2012, Resumos de teses, séc. XXI)

Há casos em que o escopo de alta polaridade positiva aparece sob a forma de um advérbio modalizador. É um espaço interessante para a gradação aproximativa via interação de modalidade x polaridade negativa. Nesses casos, vemos modalizador sobre modalizador, e a função de quase é romper com essa validade de polaridade positiva e colocar em campo uma pitada de dúvida, de incerteza ou de constatação de iminência da polaridade positiva em seu estágio de grande segurança na enunciação:

(91) Os resultados obtidos foram avaliados estatisticamente e mostram que o perfil do brasileiro é QUASE totalmente diferente do perfil do norte-americano, exceção feita a apenas quatro pontos para os homens e outros quatro, para as mulheres. (FACULDADE DE ODONTOLOGIA, 2005, Resumos de teses, séc. XXI)

(92) O estudo dos pontos singulares em campos vetoriais analíticos é um problema QUASE completamente resolvido. (INSTITUTO DE MATEMÁTICA E ESTATÍSTICA, 2012, Resumos de teses, séc. XXI)

(93) Nesse processo, foi possível notar tensões, táticas e astúcias que oportunizavam o questionamento da heteronormatividade na escola, mas a escola e as relações escolares nela presentes evidenciavam arranjos sutis para o exercício do controle, da vigilância e da garantia de um cotidiano QUASE inteiramente heterossexual. (FACULDADE DE EDUCAÇÃ̃O, 2009, Resumos de teses, séc. XXI)

(94) Em VENTO, as células Tropicais e Subtropicais (TCs e STCs) foram geradas, e elas alimentaram a ressurgência equatorial QUASE simetricamente pelo norte e polo sul. (INSTITUTO OCEANOGRÁFICO, 2006, Resumos de teses, séc. XXI)

(95) As associações sabor-local, a seqüência das associações, os locais do pareamento e a amostra oferecida antes da terceira tentativa, variaram QUASE aleatoriamente a cada dia. (INSTITUTO DE BIOCIÊNCIAS, 2008, Resumos de teses, séc. XXI)

Nos exemplos a seguir, (96) a (98), apesar de não termos o mesmo mecanismo em atuação - modalizador agindo sobre modalizador e quebrando uma polaridade positiva - constatamos que o objetivo é o mesmo dos exemplos acima e o processo é semelhante: a polaridade negativa é mobilizada como estratégia de se preservar a face 
do escrevente, e o efeito é o descomprometimento parcial com a informação declarada ou, de outro modo, o comprometimento com a afirmação parcial. Adicionalmente, não se perde de vista que os conceitos propiciados pelos advérbios são contributos à argumentação pretendida. Ao se deparar com essas palavras, o leitor acessa os frames a elas relacionados e as impressões deixadas pelas mesmas marcam a conceptualização construída durante o discurso.

(96) O povo, quando aparece, é mero figurante - muitas vezes, ridicularizado - no cenário cujos protagonistas são, QUASE inexoravelmente, os donos do poder. (ESCOLA DE COMUNICAÇÃO E ARTES, 2007, Resumos de teses, séc. XXI)

(97) Atualmente no Brasil a carne bovina é comercializada QUASE exclusivamente congelada. (FACULDADE DE MEDICINA VETERINÁRIA E ZOOTECNIA, 2011, Resumos de teses, séc. XXI)

(98) Pacientes caminhando, menos de 235 metros no teste de caminhada, QUASE certamente expressarão insatisfação marcante em relação à sua QV. (FACULDADE DE MEDICINA, 2012, Resumos de teses, séc. XXI)

O simulacro de uma comparação aproximativa e não condizente com as possiblidades de realidade é alcançada com o sequenciamento quase como. Nos exemplos seguintes, o traço irrealis é atribuído apenas pelo emprego de quase.

(99) Em suas propostas, sua autobiografia está sempre presente, QUASE como uma "terapia". (FACULDADE DE FILOSOFIA, LETRAS E CIÊNCIAS HUMANAS, 2009, Resumos de teses, séc. XXI)

(100) Para esses sujeitos o ato é QUASE como um dever. (INSTITUTO DE PSICOLOGIA, 2012, Resumos de teses, séc. XXI)

(101) (a tese) É estruturada e dividida em quatro capítulos: Arte, Arquitetura, Paisagem Urbana e Paisagismo; Arte e Arquitetura: Memória e Crítica Social; Arte e Arquitetura: Conceitos e Linguagens Comuns ou Próximas; e Parcerias Contemporâneas e Artistas Atuando QUASE Como Arquitetos. (FACULDADE DE ARQUITETURA E URBANISMO, 2010, Resumos de teses, séc. XXI) 
No exemplo seguinte, abordando o fato de a Festa do Divino Espírito Santo ser uma tradição que sobrevive - e que há esforço para que assim se mantenha - o autor aponta o que ofereceria perigo para tal: o "processo urbano-industrial, que fragmenta a vida e enfraquece as relações próximas”. Ao tratar desse perigo, o autor deixa clara, através de sua escolha lexical - sucumbiu, a intenção de enfatizá-lo. O emprego da construção quase, nesse caso, sinaliza que a tradição esteve bastante próxima, em vários momentos, segundo o autor, de sucumbir "na luta pela sua manutenção". Essa iminência justifica a necessidade de se criar, por exemplo, uma associação com o objetivo de impedir justamente o fim da tradição. Para o autor, enfatizar a proximidade que a festa esteve de desaparecer é essencial, pois a coloca como uma tradição forte, a qual resistiu ao tempo apesar das dificuldades, o que é importante para a valorização do tema de pesquisa definido.

(102) (...) herança portuguesa, as festividades em homenagem ao Espírito Santo encontraram terreno fértil no Brasil, onde ganharam contornos populares. Em Mogi das Cruzes, município pertencente à Região Metropolitana de São Paulo, a Festa do Divino Espírito Santo é realizada, segundo os documentos consultados, há quase duzentos anos. Em vários momentos, a tradição QUASE sucumbiu na luta pela sua manutenção diante do processo urbano-industrial, que fragmenta a vida e enfraquece as relações próximas. No início da década de 1990, alguns moradores de Mogi, interessados na manutenção da Festa do Divino do Espírito Santo se reuniram com o objetivo de fundar uma associação que auxiliasse na sua realização, a fim de não deixar a tradição desaparecer. (FACULDADE DE FILOSOFIA, LETRAS E CIÊNCIAS HUMANAS, 2007, Resumos de teses, séc. XXI)

O processo relatado pelo autor - um período conturbado - que culminou com a redenção anunciada da referida cadeia do álcool hidratado, no exemplo seguinte, teria ficado, anteriormente, na iminência de finalizar em morte precoce. A ideia de que a proximidade a essa morte foi a máxima possível - sinalizada por quase - enfatiza a situação crítica da cadeia.

(103) O Proálcool e especificamente a cadeia do álcool hidratado vivem atualmente um momento crucial. Recém saída de um período conturbado que, apesar de todas as regulamentações, pretensa proteção governamental, e até bom potencial mercadológico QUASE finaliza em morte precoce, tem sua redenção anunciada. A diferença fundamental é que na base da redenção anunciada está o elemento mais importante da 
cadeia: o consumidor final. Entendê-lo, decodificar suas necessidades e vontades é a chave da prosperidade. Este é o grande desafio desta cadeia como um bloco. (ESCOLA DE ENGENHARIA DE SÃO CARLOS, 2006, Resumos de teses, séc. XXI)

O que verificamos, nos exemplos a seguir, é uma tentativa de uniformizar os resultados obtidos nos períodos de coleta de dados e análise das pesquisas. Assim, por exemplo, em (104), os equipamentos públicos aparecem nas procuras por redes sociais realizadas pelos migrantes, mas, pelo emprego de quase junto ao escopo não, entendemos que os mesmos aparecem pouco. Promover uma aproximação à negação sugere uma quantidade de aparições menor do que afirmar que os equipamentos públicos aparecem pouco nas citadas procuras. O mesmo efeito ocorre nos demais dados. Em (105), observamos que os mencionados estereótipos observados foram próximos a zero ( $0,45 \%$ dos comportamentos totais). Antes da apresentação do número, o autor conduz à leitura de que os mesmos estiveram o mais próximo possível de não serem observados: quase não foram observados. No último exemplo - no qual temos a expressão quase sempre, já analisada anteriormente - a intenção do autor de enfatizar que os coinfectados não costumam procurar o posto de saúde mais próximo da residência fica ainda mais evidente devido à aparente retificação logo após a expressão quase nunca: ou às vezes. Procurando não se comprometer com a afirmação de que a procura por parte dos coinfectados pelo posto citado estaria bastante próxima de nunca ocorrer, o autor parece retificar sua asserção, empregando uma expressão - às vezes que sinaliza uma frequência maior dessa procura do que a indicada por quase nunca.

(104) Assim, inventam táticas astuciosas para enfrentar a situação de pobreza, sendo uma delas a busca por redes sociais de apoio. Os equipamentos públicos QUASE não aparecem nestas procuras por redes sociais. (INSTITUTO DE PSICOLOGIA, 2013, Resumos de teses, séc. $\mathrm{XXI})$

(105) No segundo experimento houve uma interação entre os animais e a proposta de layout do alimentador avaliado. Estereótipos QUASE não foram observados, totalizando somente $0,45 \%$ dos comportamentos totais, indicando um baixo nível de stress. Interações agressivas também não foram significativas $0,90 \%$, ocorrendo somente nos primeiros dias. (ESCOLA SUPERIOR DE AGRICULTURA "LUIZ DE QUEIROZ”, 2013, Resumos de teses, séc. XXI) 
(106) Os resultados sugerem que as atividades desenvolvidas, tanto no contexto institucional quanto na sala de aula, privilegiam as situações de recognição e são pautadas pelas relações de controle e poder. Desse modo, QUASE não há espaço para a invenção e para a aprendizagem significativa. (FACULDADE DE FILOSOFIA, LETRAS E CIÊNCIAS HUMANAS, 2011, Resumos de teses, séc. XXI)

(107) Com referência à colaboração realizada entre os autores, notou-se diminuição da produção em autoria única, com predomínio das publicações com 2 e 3 autores. Entretanto, a cooperação se deu entre autores do mesmo país e instituição, QUASE não havendo estudos com colaboração internacional. (ESCOLA DE COMUNICAÇÃO E ARTES, 2009, Resumos de teses, séc. XXI)

(108) O "pacto de melhor comprador" é uma cláusula especial ao contrato de compra e venda que sujeita os efeitos desta ao oferecimento, dentro de um determinado prazo, de melhores condições (vantagens) por terceiro. Ao longo dos mais de 80 anos de vigência do Código Civil de 1916 (onde era expressamente previsto - artigos 1.158 e seguintes), QUASE não foi estudado, porque dificilmente era aplicado. Os poucos estudiosos que o comentavam (brevemente) não indicavam as causas mais relevantes do seu desuso: a restrição do seu objeto às coisas imóveis e a existência de uma outra cláusula que o substituía eficazmente (a "retrovenda"). (FACULDADE DE DIREITO, 2004, Resumos de teses, séc. XXI)

(109) PA - não tem formulário para solicitar baciloscopia, não tem pote para coleta de escarro; tem equipamento de Raio-x; local muito ruim destinado à coleta de escarro; QUASE nunca há disponibilidade suficiente de profissionais; sempre tem sobrecarga de trabalho; não solicitam baciloscopia; sempre apresentam dificuldade para convencer o doente a colher escarro. (ESCOLA DE ENFERMAGEM, 2013, Resumos de teses, séc. XXI)

(110) A partir dos dados observados houve diferenças estatisticamente significativas quanto as variáveis acesso ao diagnóstico cujos doentes com TB e coinfectados QUASE nunca ou às vezes procuram o posto de saúde mais próximo da residência e os doentes com TB QUASE sempre procuram o posto de saúde mais próximo da residência. Como também, houve diferenças estatisticamente significativas no acesso ao tratamento sendo que, o profissional da saúde visita mais vezes os doentes acometidos pela coinfecção quando comparados com os doentes que não apresentam a coinfecção e os doentes coinfectados QUASE nunca realizam o tratamento da doença em um posto de saúde perto da residência. (ESCOLA DE ENFERMAGEM, 2009, Resumos de teses, séc. XXI) 
Ilustramos, a seguir, os casos em que quase atua como elemento compositivo de locuções quantificadoras em processo construcional:

(111) Na literatura, existem diversos algoritmos e heurísticas propostos para abordar este problema. Porém, QUASE nenhuma dessas técnicas explora o fato que existem funções custo cujos valores são estimados a partir de uma amostra e que descrevem uma "curva em U" nas cadeias do reticulado Booleano $(\mathrm{P}(\mathrm{S})$; um fenômeno bem conhecido em Reconhecimento de Padrões. (INSTITUTO DE MATEMÁTICA E ESTATÍSTICA, 2013, Resumos de teses, séc. XXI)

(112) O tipo de sistema de circulação de células utilizado não influenciou estatisticamente QUASE nenhuma das respostas estudadas e isto indica a possibilidade de substituição do sistema tradicional airlift pelos outros testados neste trabalho. (INSTITUTO DE QUÍMICA, 2012, Resumos de teses, séc. XXI)

Compondo locuções quantificadoras, a construção quase é empregada junto à palavra nenhuma e as intenções comunicativas são, novamente, as já explanadas. Mais especificamente, em (111), a preservação da face é necessária por se tratar de afirmação que pode ser contestada - as técnicas estão disponíveis a todos na literatura. Enquanto em (112), visa-se à uniformização dos resultados da pesquisa.

Nos contextos, ainda, em que se toma a palavra sem como escopo, quase constitui outro tipo de locução quantificadora. No primeiro exemplo, podemos hipotetizar que manter a corrente completamente sem distorções não seria algo possível. Logo, o autor serve-se da construção quase para indicar que a condição por ele criada em sua pesquisa aproxima-se o máximo possível do que seria uma corrente sem distorções, as quais são, portanto, as mínimas possíveis. No exemplo seguinte, ao dividir em quatro períodos a exposição do Brasil e do mundo ao benzeno, o autor precisa demarcar com clareza o que diferencia um período de outro. Uma vez que o segundo período teria sido marcado pelo aumento significativo da utilização e da importância das exposições à substância, a ênfase a pouca utilização e exposição no primeiro período torna-se necessária. O momento inicial é, desse modo, marcado pelas expressões pouco - a qual se refere ao uso do benzeno - e quase sem - referente às notícias de casos de exposição a ele. Ambas sinalizam a grande distinção entre o que foi 
considerado como o primeiro período, para o autor, e o que se caracterizou como o segundo.

(113) Por fim, a validação da proposta é feita através dos resultados de simulações e experimentais que mostram a capacidade do sistema de geração em transferir potência constante para a rede de distribuição e manter a corrente QUASE sem distorções. (ESCOLA DE ENGENHARIA DE SÃO CARLOS, 2013, Resumos de teses, séc. XXI)

(114) Os resultados mostraram que, no Brasil e no mundo, pode-se dividir em quatro períodos a exposição a benzeno. Um inicial, com pouco uso e QUASE sem notícias de casos. Um segundo momento em que a utilização aumenta de forma significativa e as exposições se tornam importantes (....) Um terceiro período em que há uma mudança de perfil de exposição com a proibição de presença de benzeno em solventes e uma diminuição das concentrações ambientais. (FACULDADE DE MEDICINA, 2009, Resumos de teses, séc. XXI)

Por fim, um último padrão é identificado. Juntando-se ao escopo nada para, mais uma vez, compor uma locução quantificadora, a construção quase é empregada por motivos diversos - mas já verificados em outros casos - nos exemplos anteriores. Em (115), verificamos que quase nada impõe valorização ao tema de pesquisa escolhido. Ressaltar o quão pouco trabalhadas foram as populações africanas, por parte do romantismo literário brasileiro, confere relevância à pesquisa, a qual definiu como seu objeto de estudo a obra de um autor ex-escravo e abolicionista. A insegurança do escrevente em realizar uma afirmação categórica, como seria "mas nada falou sobre as populações africanas", mantém-se mesmo perante a asserção de um autor provavelmente, um estudioso a respeito do assunto em questão - segundo a qual, haveria um longo silêncio, no romantismo literário brasileiro, sobre as etnias negras que povoaram o Brasil. Ainda assim, o pesquisador opta por preservar-se e recorre, no momento de apresentar uma reflexão própria, ao emprego de quase antes de nada. No exemplo posterior, a intenção também é a de não comprometimento com uma afirmação categórica. Afinal, sabe-se que, ao menos, alguma pequena mudança no cenário de escassez deve ser suscitada pela inclusão dos referidos recursos. O autor tenciona, ao empregar quase antes de nada, indicar que essa mudança é a mínima possível, estabelecendo, ainda, o contraste com o efeito causado por esses mesmos recursos quando aplicados ao movimento educacional, os quais seriam, nesse caso, 
significativos. A redução mais próxima possível ao nada cria o contraste que exalta o fato de esses recursos tornarem-se significativos em outro contexto, no caso, o educacional. Leiamos mais detidamente esses exemplos analisados:

(115) O romantismo literário brasileiro conseguiu fabricar um modelo de índio civilizado despido de suas características reais, mas QUASE nada falou sobre as populações africanas, houve "um longo silêncio sobre as etnias negras que povoavam o Brasil" (ORTIZ, 2003: 19). Por isso, optamos por estudar analiticamente a obra Primeiras trovas burlescas de Getulino, do ex-escravo, escritor, abolicionista, jornalista e advogado Luiz Gama. (FACULDADE DE FILOSOFIA, LETRAS E CIÊNCIAS HUMANAS, 2010, Resumos de teses, séc. XXI)

(116) $\mathrm{Na}$ escassez de recursos e preocupação com a instabilidade econômica em decorrência do aumento da pobreza, o Banco Mundial programa empréstimo e orientações visando a eficiência e ampliação da oferta do Ensino Médio, do qual o Governo de Estado participa. A inclusão de recursos do PROMED e da comunidade aos recursos oficiais advindos dos impostos não muda em QUASE nada o cenário da escassez, dado os montantes serem irrisórios, mas no movimento educacional se tornam significativos, por se tratarem de recursos novos. (FACULDADE DE EDUCAÇÃO, 2008, Resumos de teses, séc. XXI)

Notamos, assim, que estratégias similares são apresentadas nas várias amostras, com uma diferença: nos resumos de teses identificamos algumas estratégias mais elaboradas para marcar a modalização. Provavelmente isso se deva ao próprio tipo de texto ser também mais complexo em conteúdo e forma, o que demanda maior esforço cognitivo do indivíduo para formulá-lo a contento.

\subsection{Organização dos padrões do item quase}

Após cumprir a análise com as várias amostras e perceber que as estratégias são muito próximas em propósitos, detemo-nos a buscar um critério que permitisse distribuir esses dados em padrões intencionalmente distintos, ou seja, distribuídos numa gradação de esforço cognitivo à apreensão. As ferramentas mais eficientes são, como já argumentamos, o princípio de iconicidade. Para essa reflexão, lançaremos mão dos dados já analisados anteriormente. 


\subsubsection{Subprincípio de quantidade}

A inserção da partícula que entre quase e seu escopo revelou-nos uma maior complexidade dos dados intersubjetivos, pois quanto mais forma é colocada sintaticamente, mais complexos são os itens em suas funções sintática, semântica e pragmática. Além disso, quanto mais forma for inserida entre dois itens, afastando-os sintaticamente, mais distantes estarão também cognitivamente. Portanto, a intenção de atenuação do valor categórico é ainda maior nesses dados e está codificada sintaticamente. São intenções codificadas sintaticamente, são intenções gramaticalizadas na língua. Com esse recurso altamente elaborado, o autor/escrevente distancia-se ainda mais da responsabilidade sobre sua afirmação. Adicionalmente, considera-se a informação codificada mais complexa.

(117) E demais um mercado no centro da cidade é | muito mais conveniente do que collocado QUASI QUE em um arrebaldo, e precisando para lá ir-se | descer e subir ladeira. (Carta de Leitor, 1887, séc. XIX)

(118) No Brasil o que temos é uma QUASE QUE completa negação da auto-estima. (FUVEST, 2003, Redações dissertativas, séc. XXI)

(119) Um país marcado por um processo colonial explorador e cujo domínio político foi reservado QUASE QUE exclusivamente a uma elite econômica preocupada com seus próprios interesses só poderia abrigar uma população com baixo nível educacional, sujeita a manipulações ideológicas que a transformem em uma massa passiva. (FUVEST, 2003, Redações dissertativas, séc. XXI)

(120) Uma tragédia na Ásia, por exemplo, é noticiada QUASE QUE em tempo real para o mundo todo. (FUVEST, 2005, Redações dissertativas, séc. XXI)

(121) Apesar da evolução da humanidade, os ensinamentos bíblicos permaneceram intactos, tornando-os QUASE QUE totalmente inadequados à realidade atual. Não são mais aceitos os conceitos de sexo e família propostos pelo catolicismo, e há uma relutância por parte do clero em se adaptar aos novos tempos. (FUVEST, 2010, Redações dissertativas, séc. XXI)

(122) Se a unidade religiosa e cultural, antes, resultava numa solidariedade vinculante esta se dava QUASE QUE apenas entre iguais e a um preço alto, necessidade de filiação e pouca liberdade pessoal. $O$ 
processo de desenvolvimento social levou, sem dúvida, a uma fragmentação e à individualização, já que o indivíduo não tem mais identidade definida. (...) (FUVEST, 2011, Redações dissertativas, séc. XXI)

(123) A QUASE QUE onipresença dos meios de comunicação na atualidade força insistentemente o contato com a imagem. Esse contato hipertrofia uma intimidade natural, de modo que, sendo a imagem uma abstração simbólica, a própria experiência se funde com o que se enxerga nela. (FUVEST, 2010, Redações dissertativas, séc. XXI)

(124) Esse método eliminou QUASE QUE completamente a matriz orgânica, gerando os menores limites de detecção e tornou a introdução da amostra no equipamento mais fácil. (INSTITUTO DE QUÍMICA, 2012, Resumo de teses, séc. XXI)

(125) Dados sobre violência policial de inúmeros orgãos, pesquisas acadêmicas no assunto, e a própria preocupação manifesta de autoridades governamentais de segurança pública tornam QUASE QUE inevitável que essas discussões vinculem a polícia à violência. (INSTITUTO DE PSICOLOGIA, 2012, Resumos de teses, séc. XXI)

(126) $\mathrm{O}$ estudo sobre a natureza da relação entre as práticas recomendadas de gestão de TI e seus resultados partiu da análise de 37 modelos de governança, sendo 15 específicos de GTI, dos quais três modelos foram escolhidos - CObIT vs.4.1, eSCM-CL vs.1.1 e ITIL vs.3 - por representarem QUASE QUE a totalidade de processos e ações práticas de todos os outros modelos relacionados à GTI. (FACULDADE DE ECONOMIA, ADMINISTRAÇÃO E CONTABILIDADE, 2011, Resumos de teses, séc. XXI)

Um sintagma nominal é constituído por artigo + nome e, no exemplo (123) acima, o que temos é artigo + QUASE + nome, ou seja, não é exatamente um sintagma nominal simples, é complexo. Além disso, colocada no meio do sintagma nominal, a expressão quase que distancia artigo e substantivo. Diferentemente do que ocorre em outros dados de caráter mais intersubjetivo, em que temos como processo atuante o de aproximação a um grau de uma escala de graus de modalidade, o que temos, no exemplo acima, é a aproximação a um conceito, o qual pode ser imaginado como uma "esfera ${ }^{154 "}$. Isso ocorre nos dados em que quase toma como escopo um substantivo, como poderemos observar em outros exemplos presentes a seguir. A construção quase, nesses casos, promoveria uma aproximação máxima a essa esfera, enquanto que nos

${ }^{154}$ Empregamos aqui a ideia de "esfera" como uma metáfora para o conceito de protótipo. 
dados vinculados à escala de graus de modalidade, o processo atuante seria o de aproximação máxima a um determinado grau. Podemos visualizar esses mecanismos do seguinte modo:
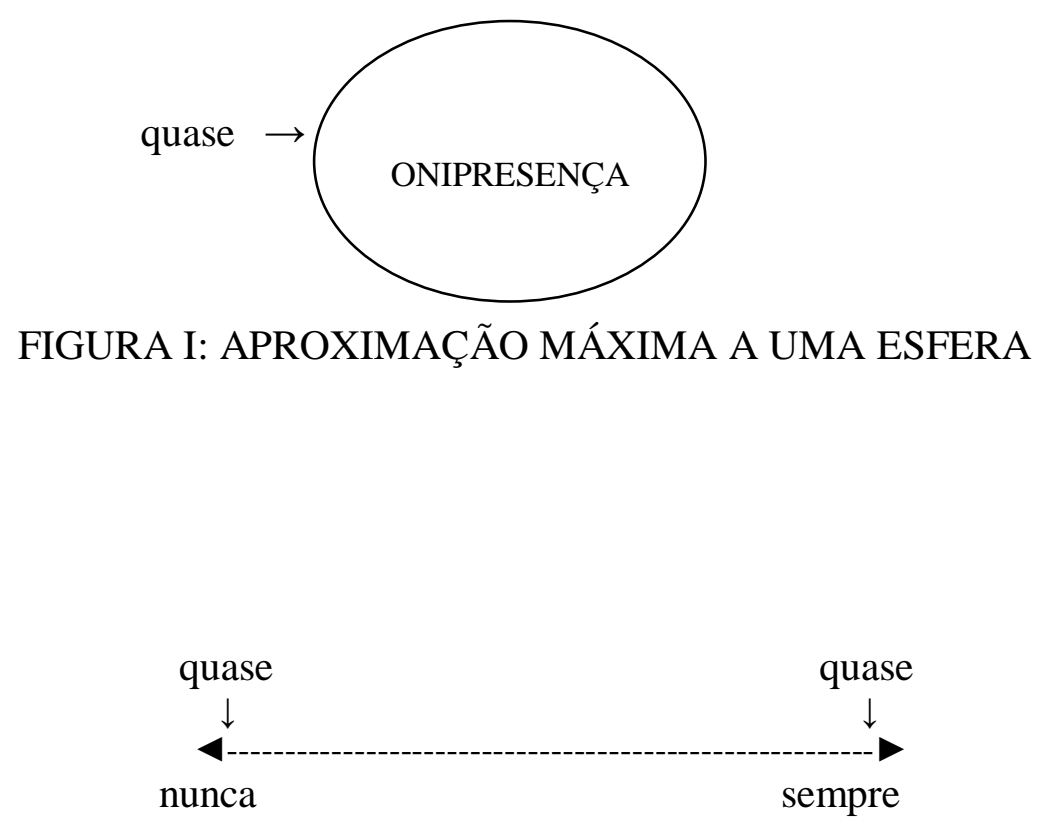

FIGURA II: APROXIMAÇÃO MÁXIMA A UM GRAU DE UMA ESCALA

\subsubsection{Subprincípio de distância}

O distanciamento entre informações na sintaxe revela um distanciamento cognitivo entre as mesmas. Assim, quanto mais distantes as informações estiverem cognitivamente, ou seja, na representação mental do escrevente, mais forma será inserida entre elas, de modo a torná-las sintaticamente distantes, codificando o distanciamento cognitivo via sintaxe.

(127) Há, ainda, uma ideia mais sutil, segundo a qual o passado está presente no presente. Porém, para os que acreditam nessa, o passado contido no hoje é um passado mais de sentimentos do que de datas ou de tratados assinados. É um passado que é QUASE um desvanecer... (FUVEST, Redações dissertativas, 2004, séc. XXI) 
Numa construção equativa, espera-se que dois elementos se equivalham semanticamente. Com o emprego da palavra quase, uma partícula que remete a uma iconicidade de distância, o efeito é justamente o de distanciar o fato de sua propriedade equativa, ou seja, formalmente verifica-se que não é de fato uma equação. Esse recurso altamente argumentativo produz um efeito de quebra na construção equativa $\mathrm{x}$ é $\mathrm{y}$, que passa a codificar x é QUASE y. Quase Y não é o mesmo que Y.

(128) Criou-se QUASE uma teoria conspiratória para basear o manifesto ${ }^{155}$. A julgar pelo monumento, o programa parece, apesar das boas intenções, passar longe de uma solução para os problemas que expõe. (FUVEST, 2005, Redações dissertativas, séc. XXI)

(129) Ademais, como esperar pelo altruísmo e pelo pensamento à longo prazo da humanidade pós guerra-fria, quando os governos e a população pouco cedem de seus hábitos não sustentáveis, a favor de políticas ou comportamentos menos destrutivos ao meio ambiente (vide a crise do "Código Florestal Brasileiro" e a QUASE falência do "Protocolo de Kyoto") ? (FUVEST, 2011, Redações dissertativas, séc. XXI)

(130) A hipótese não é rejeitada, observando-se um efeito positivo da segregação para brancos e amarelos e, negativo para negros, fato que se relaciona com a QUASE inexistência de pretos e pardos em escolas particulares. (FACULDADE DE ECONOMIA, ADMINISTRAÇÃO E CONTABILIDADE, 2012, Resumos de teses, séc. XXI)

(131) Trata-se de livros que facilitam conhecimentos e fornecem conselhos práticos aos professores, constituindo QUASE uma literatura de autoajuda pedagógica. (FACULDADE DE EDUCAÇÃO, 2012, Resumos de teses, séc. XXI)

(132) A estabilidade do Orçamento Autorizativo no Brasil é analisado em seguida e pode ser visto como um caso complementar aos demais, pois trata de uma QUASE mudança institucional. (FACULDADE DE FILOSOFIA, LETRAS E CIÊNCIAS HUMANAS, 2010)

(133) Para testar esta hipótese realizamos um QUASE experimento com dois grupos não-equivalentes. (FACULDADE DE FILOSOFIA, LETRAS E CIÊNCIAS HUMANAS, 2011, Resumos de teses, séc. XXI)

(134) Os estudos cinéticos em diversos eletrólitos e temperaturas demonstram que o eletrodo de DDB caracteriza-se pela QUASE

\footnotetext{
${ }^{155}$ Refere-se ao fato de o grupo artístico "Contra Filé" ter colocado, no Largo do Arouche, na cidade de São Paulo, segundo a coletânea de textos da proposta de redação do concurso vestibular da FUVEST, uma catraca enferrujada e deteriorada, acompanhada de uma placa que a denominava "Monumento à Catraca Invisível”.
} 
ausência de sítios de adsorção - causa dos elevados sobrepotenciais e energias de ativação para a RDO.

Os objetos direto e indireto, nessas ocorrências - (128) a (134), não são objetos prototípicos. Eles se distanciam de sua semântica.

Essa reflexão sobre a atuação do princípio de iconicidade propiciou que intuíssemos a existência de uma escala de envolvimento do sujeito escrevente em três padrões organizadores do conjunto de dados. A ideia é que a intenção de se aproximar argumentativamente do leitor-interlocutor seja codificada sintaticamente por meio de uma gradação de subjetividade, o que explicitaremos na seção seguinte.

\subsection{Subjetividade Escalar nos usos de Quase e Quase que}

Na proposta que apresentamos, três são os padrões operantes: menos subjetivo (porque não concebemos uma objetividade isenta do sujeito), subjetivo propriamente dito e intersubjetivo.

\subsubsection{Usos menos subjetivos}

Nos exemplos menos subjetivos, observa-se o emprego de quase na expressão de valores imprecisos. Nesses usos, o falante favorece a depreensão de sua intenção de situar o referente num espaço circunstancial de observação mais precisamente.

a) imprecisão espacial: mobilizando advérbios e locuções adverbiais locativas, configura uso menos subjetivo porque seu escopo ganha imprecisão quando o falante não consegue situar numérica ou geograficamente de forma mais certeira uma informação. No exemplo (135) a seguir, há uma codificação de limite dessa imprecisão (aproximadamente defronte à casa, mas sem alcançar esse ponto limite). Esse tipo de uso aparece nas três amostras sob investigação.

(135) Um po- | bre môço carreiro de 10 a 12 annos que | servia de arrimo a sua desgraçada familia, | tendo marchado 3 ou 4 leguas por entre | máos caminhos, chegou sem perigo | até as portas da Cidade; na continuação po- | rém da rua da Esperança QUASI defronte | á casa do Conego Leão (sendo a rua prin- | cipal e unica para a entrada de todos os $\mid$ carreiros \& 
que vem de Sancto Amaro) em | um lamaçal tremendo que alli existe ato| la-se o carro, perde o equilibrio, e queren- | do o infeliz encostar a lenha ficou espedaçado | debaixo do peso enorme; e no mais lamentavel | estado hontem deu-se á sepultura, deixan- |do sua familia desolada, e sem este arrimo. (Carta de Leitor, 1828, séc. XIX)

Esse nos parece o exemplo menos subjetivo entre todos por nós identificados. A intenção comunicativa parece consistir na informação a respeito da localização espacial em que o indivíduo citado se encontrava no momento do acidente. A palavra quasi é empregada para indicar a proximidade do local a um ponto, - a casa do Conego Leão ao que parece, conhecido pelos moradores da cidade, o que facilita a esses reconhecer a localização em que ocorreu o acidente. Nesse exemplo, a construção em questão é empregada como aproximativo espacial e, apesar de funcionar como recurso para facilitar o reconhecimento de uma localização, ou seja, apesar de sinalizar uma intenção comunicativa que vai além de uma simples aproximação espacial, possui um caráter menos subjetivo.

(136) Arriscamos nossas vidas por um futuro melhor, estamos em guerra com nós mesmos. Não há barreiras que eu não possa quebrar, não há limites. Chegar! Estamos QUASE lá, na fronteira do México e EUA. Agora é tentar passar, pelo menos lutamos, ou desistir e ver o sonho não realizado. Estamos na fronteira dos pensamentos, a fronteira que me cerca entre o coração e a razão. (FUVEST, 2009, Redações dissertativas, séc. XXI)

Apesar da sinalização de uma aproximação aparentemente muito concreta no exemplo (136) - "estamos próximos à fronteira do México e EUA" - notamos, pelo tom bastante subjetivo do trecho, que a construção quase parece ter sido empregada para indicar a proximidade de um sonho, o qual, para ser realizado, exige que fronteiras sejam ultrapassadas. Uma vez que o tema proposto para a redação desse ano referia-se a fronteiras, o escrevente faz alusão ao movimento de imigrantes mexicanos para os EUA em busca de melhores condições de vida como um sonho o qual é impedido pela fronteira. $\mathrm{O}$ escrevente parece mais referir-se à ideia de proximidade a um sonho do que de proximidade à fronteira entre México e EUA. A expressão Estamos quase lá parece significar o seguinte: estamos quase alcançando nosso sonho. 
b) imprecisão quantitativa: mobilizam-se numerais cardinais, fracionários, multiplicativos ou em forma de porcentagens e o adjetivo nulo e suas flexões, por meio dos quais se busca uma maior precisão da informação. Dado esse caráter de precisão requerido, o gênero resumo de teses revelou-se apropriado para esse uso, o que se explica na intenção do escrevente em identificar dados e números que representem, ainda que aproximativamente, informações mais científicas.

(137) Além de ser previsto em lei, o tratamento da fração orgânica se faz necessário já que no Brasil são gerados QUASE 100 mil toneladas por dia de resíduos orgânicos. A maioria desses resíduos é atualmente disposta em aterros sanitários. (ESCOLA DE ENGENHARIA DE SÃO CARLOS, Resumos de teses, 2013)

(138) mostrou que o OLAM v3.3 subestima a energia do sinal intrasazonal na região do oceano Índico em QUASE a metade do valor real observado. (INSTITUTO DE ASTRONOMIA, GEOFÍSICA E CIÊNCIAS ATMOSFÉRICAS, Resumos de teses, 2012)

(139) O consumo excessivo de carne foi observado em QUASE 75 por cento das pessoas e o tipo de carne mais consumido nos dois períodos foi a bovina (FACULDADE DE SAÚDE PÚBLICA, Resumos de teses, 2012)

(140) A viabilidade para o período ovoadulto foi QUASE duas vezes superior à viabilidade obtida na dieta natural, sendo de $68 \%$ em relação aos $38 \%$ obtidos na dieta natural (ESCOLA SUPERIOR DE AGRICULTURA “LUIZ DE QUEIROZ”, Resumos de teses, 2012)

O que observamos nos exemplos (137) a (140) acima é, novamente, a intenção de causar, nos leitores, a impressão de amplitude, sem que haja, porém, comprometimento por parte do autor. A ideia é enfatizar as quantidades para, assim, dar destaque aos dados apresentados pela pesquisa. A exposição de um dado de forma imprecisa, possibilitada pelo emprego de quase, conduz o leitor a assumir como informação uma quantidade maior do que aquela a qual seria indicada pela quantificação exata, precisa.

(141) Os títulos vacinais tenderam a baixar rapidamente nos meses subsequentes à vacinação, sendo QUASE nulos após seis meses das 
revacinações. (FACULDADE DE MEDICINA VETERINÁRIA E ZOOTECNIA, Resumos de teses, 2005)

(142) Em condições hidrodinâmicas pouco turbulentas, a recuperação de partículas grossas decresce em função de falta de suspensão de partículas, por outro lado para condições hidrodinâmicas mais severas a recuperação foi QUASE nula devido à destruição do agregado partícula/bolha. (ESCOLA POLITÉCNICA, Resumos de teses, 2010)

Nesses casos, (141) e (142), a intenção é atentar para o fato de determinados valores estarem bastante próximos a zero. Essa ideia torna-se muito mais enfática através do emprego de uma expressão como "quase nulos" do que seria com uma informação precisa.

c) imprecisão temporal: mobilizam-se advérbios e locuções adverbiais temporais presentes nas amostras de cartas e de resumos de teses. Nesses casos, os escopos prestam-se à estratégia de conferir maior precisão temporal, a qual é impedida, devido a diversas intenções comunicativas, pelo emprego de quase.

(143) O nosso intuito, como os leitores d'A Platéa viram pela importancia dos despachos que inserimos, teve completo exito, mas, para realizal-o, fomos obrigados a retardar a edição da folha em virtude dos ultimos desses telegrammas serem recebidos QUASI às tres horas. Esse facto privou-nos de fazer a habitual remessa para as localidades servidas pelos trens da tarde. || De semelhante falta, aliás commettida no interesse de bem servir aquelles que nos leem, pedimos desculpas aos nossos agentes. (Carta de Redator, 1900, século XIX)

Na ocorrência (143), presente em uma carta escrita por um redator, a palavra quasi é empregada para indicar uma aproximação a um escopo de maior precisão temporal - às três horas. $\mathrm{O}$ escrevente referia-se a um horário algo anterior a esse. $\mathrm{O}$ objetivo da carta parece ser o de desculpar-se junto aos leitores que não teriam recebido a referida edição do jornal. Segundo o redator, o motivo de tal acontecimento teria sido o atraso no recebimento de determinados telegramas e, consequentemente, o retardo da edição do jornal. Uma vez que a questão do horário em que os telegramas foram recebidos desempenha papel central - foi o fator desencadeador de todo o atraso - é importante ao escrevente enfatizar o quão tardio foi esse horário. Às três horas, 
provavelmente, sinaliza um horário bastante tardio para o contexto, algo que poderia, inclusive, soar como um exagero frente ao real horário em que os telegramas chegaram. O redator recorre, portanto, ao emprego de quasi como recurso para amenizar o que poderia soar como exagero. Apesar desse provável caráter modalizador da construção nessa ocorrência, decidimos mantê-la dentre os padrões menos subjetivos, conforme explanamos anteriormente.

\subsubsection{Usos subjetivos propriamente ditos}

Nos exemplos prototipicamente subjetivos, observa-se a ação do autorescrevente ao manipular as informações. Essas intervenções mascaram-se na combinação de polaridades e um jogo de sombras entre positivo e negativo e também negativo e negativo, produzindo a imprecisão, mas demandando maior atenção para essa compreensão.

a) ênfase na percepção de proximidade do escrevente: mobilizam-se para esse efeito partículas que atribuem traço de polaridade negativa a um item de polaridade altamente positiva, com traço de indefinição ou imprecisão. O escopo preferencial é o conjunto de termos de alta polaridade positiva, tais como todo e suas flexões, tudo, totalidade, total, sempre. $\mathrm{O}$ efeito de sentido permite aproximar um item ou um conjunto de itens a um conjunto da totalidade dos itens a que se vinculam, entrelaçando-se semanticamente ou sendo julgados como um macroconjunto em termos de categorização. O processo envolvido difere, entretanto, em cada caso: em quase todos (as) e quase tudo temos em atuação o processo de quantificação, o qual consiste na seleção da maior quantidade de membros de um conjunto; em quase todo (a), o que temos é a seleção da maior parte de uma "massa", ou seja, a partitude é o processo envolvido; ao tomar totalidade como escopo, o que acontece em expressões como quase em sua totalidade, quase a totalidade, é a atuação de um dos processos acima descritos (quantificação ou partitivo) a depender do caso; em quase total e em quase sempre, guardadas as devidas particularidades, atua o processo de aproximação ao polo de uma escala constituída por graus de modalidade. Assim, no caso do escopo sempre, imaginaríamos uma escala cujos polos seriam nunca e sempre. O emprego de quase promoveria a aproximação a 
esse último polo. No caso do escopo total, podemos pensar em uma escala que iria de nulo (a) até total, passando, por exemplo, por parcial.

(144) Alli veria o Senhor Popoia, que nos conformamos com QUASI todas as suas opiniões divergindo comtudo em algumas, que ainda mesmo depois de recebermos a sua correspondencia não podemos adoptar. (Carta de Redator, 1827, séc. XIX)

É curioso como, no exemplo (144) acima, o escrevente parece redundante em seu discurso. Após informar que teriam se conformado com quase todas as opiniões do Senhor Popoia, o redator reforça com a informação de que teriam divergido comtudo em algumas. A construção quase atua justamente atribuindo traço de polaridade negativa a seu escopo, ou seja, nesse caso, indicando uma proximidade à totalidade de opiniões. Sabe-se, portanto, que a conformação não foi com todas as opiniões, mas com uma quantidade de opiniões bastante próxima à quantidade total. Não há, dessa forma, necessidade de afirmar que houve divergência a respeito de algumas opiniões. Essa é uma informação já sinalizada pelo emprego de quase. O escrevente, no entanto, reafirma-a e, ainda, apresenta essa redundante afirmação através do emprego da conjunção adversativa comtudo, que sinaliza ideias de oposição e compensação, conceitos não condizentes com a relação estabelecida entre as informações nesse trecho, as quais seriam equivalentes. É importante observar que as opiniões divergentes precisaram ser trazidas para o discurso, pois o redator objetivava afirmar, em seguida, que mesmo depois de receberem a correspondência do referido senhor, essas opiniões não poderiam ser adotadas. A forma de introduzi-las ao texto foi, como observamos, errônea, mas talvez a necessidade de fazê-lo justifique a redundância, a qual consistiria no recurso encontrado pelo escrevente para dar destacar as opiniões que, dentro daquela totalidade, eram divergentes. Já o emprego da conjunção adversativa comtudo denuncia uma atitude do escrevente a respeito da construção quase. Imaginamos que o caráter aproximativo dessa construção seja bastante enfático para o escrevente em questão, em outras palavras, esse parece considerá-la como o recurso capaz de promover a máxima aproximação possível, no caso, à totalidade indicada. Assim, devido a esse caráter de quase, ao afirmar, novamente, ainda que de uma nova forma, que não houve 
conformação com a totalidade das opiniões, o escrevente considera necessária a utilização da conjunção comtudo.

(145) Sempre fomos inimigos de partir em diversos numeros os nossos artigos, porque muito sabemos quanto é incommodo, e quanto esfria os Leitores um - continuar-se-ha - mas entendemos, que apezar d'isso aquelles que reffectidamente lerem esta obra prima agradeceráõ sua impressão. Este artigo tem sido traduzido destacado em QUASI todas as lingoas da Europa; entre nós apparece um pouco tarde, mas ainda a tempo, porque o que é bom vem sempre a tempo. (Carta de Redator, 1830, séc. XIX)

Tratando-se de uma carta na qual o objetivo do redator é informar a respeito da publicação de um artigo e exaltá-lo, a afirmação de que esse tem sido traduzido em quasi todas as lingoas da Europa contribui para essa exaltação. O mecanismo atuante que temos aqui é aquele já explanado, o qual envolve a aplicação do recurso da imprecisão como forma de valorizar o dado, surtindo um efeito que não seria alcançado através de uma informação precisa, exata. A expressão quasi todas as lingoas da Europa confere grande abrangência à tradução do artigo sem que haja comprometimento por parte do escrevente, o que se deve ao caráter aproximativo e impreciso da construção quase.

(146) (...) sendo | elle um rapazinho fraco, que até tem medo de defunto, | e que nunca fez mal a ninguem - a não ser aquellas | porretadas que deu aquella noite no Mané Bafejador, | não póde servir p'ra soldado. || Manduca, comadre, é muito bãozinho; tem inclina- | ção p'ra QUASI tudo, menos p'ra soldado; elle faz gaiol- | la, caça passarinho, faz briga de gallo, toca muito bem | viola... joga o truque, e é tão habilidoso que sempre | ganha; mas (honra lhe seja feita), por não admittir | bandalheiras, as vezes briga, dá e apanha... enfim os | cobres sempre traz. (Carta de Leitor, seção "a pedido", 1865, séc. XIX)

Temos, em (146), uma carta escrita por um leitor, a mãe de um rapaz manifesta sua aversão à possibilidade de este ser convocado como soldado, destacando que o mesmo não possuiria as características e habilidades necessárias. $\mathrm{O}$ recurso utilizado para enfatizar essa ideia é o contaste entre as expressões quasi tudo e menos p'ra soldado. Segundo a mãe, ser soldado seria a única habilidade para a qual seu filho não 
teria inclinação. A expressão quasi tudo é empregada para enfatizar essa falta de habilidade para ser soldado, o que seria o objetivo maior da escrevente em sua carta. $\mathrm{O}$ emprego de menos, entretanto, causa estranhamento em uma análise mais detida. Talvez sua presença no trecho fizesse mais sentido se atuasse em oposição a uma expressão como "tem inclinação para tudo", uma vez que quasi, devido a sua polaridade negativa, ao atuar sob seu escopo - tudo - já indica que o rapaz não tem inclinação para alguma ou algumas funções, o que torna curioso o emprego da palavra menos. Consideramos esse caso como semelhante ao da utilização da palavra comtudo em exemplo anterior. Acreditamos que o emprego de menos aqui também sinalize o reconhecimento, por parte da escrevente, da construção quasi como o recurso capaz de promover a máxima aproximação possível, nesse caso, à totalidade de habilidades existentes.

(147) Erão ao todo de 40 a 50 pessoas. \|| A 16 minutos depois do meio dia partio a locomotiva | daquelle ponto. || Lia-se o enthusiasmo e alegria em todos os rostos. || Erão QUASI todos paulistas: santo era o jubilo que | exaltava o peito de filhos, que vião sua mãe adiantar | um grande passo na carreira do progresso! (Carta de Leitor, seção "comunicados", 1865, séc. XIX)

(148) Corria-se, a velocidade crescia progressivamente! \| Em breve o balanço foi tanto que o equilibrio faltava! || Não era mais um carro em caminho de ferro, era um | navio sobre as ondas de um mar batido por um tempo- | ral desfeito: QUASI todos procurarão segurança no fun- | do dos carros ajoelhando-se ou assentando-se, porque | a posição de pé já importava um risco iminente. (Carta de Leitor, seção "comunicados", 1865, séc. XIX)

Pertencentes à mesma carta, os trechos (147) e (148) relatam um acidente ocorrido com uma locomotiva. Descrevendo, inicialmente, a alegria dos passageiros por estarem participando da referida viagem, o escrevente descreve o acidente de forma bastante detalhada e emotiva. No primeiro trecho, o objetivo era o descrever a alegria que acometia os passageiros - o que contrastará com o acidente, tornando o tom da carta ainda mais emocional - e exaltar a realização da viagem pelo Estado de São Paulo, acontecimento que, para os cidadãos, era sinônimo de grande progresso. Daí a necessidade do escrevente de uniformizar sua descrição, em certo sentido, e afirmar que erão quasi todos paulistas, como forma de introduzir a questão de estarem orgulhosos pelo progresso de seu Estado. No segundo trecho, referente ao acidente, o emprego de 
quasi parece estar associado, novamente, ao desejo de uniformização. Intencionando demonstrar o desespero vivido pelos passageiros, o escrevente afirma que quasi todos tentaram se proteger ajoelhando-se ou sentando-se, o que transmite ao leitor a impressão de que a comoção foi geral entre os passageiros, descrição essa que contribui para o tom emocional conferido pelo escrevente ao relato, ao mesmo tempo em que impede que a reprodução dos fatos pareça exagerada aos olhos dos leitores, sensação que poderia ocorrer caso o escrevente afirmasse que todos os passageiros agiram da mesma forma naquele momento. Portanto, o caráter impreciso de quasi é utilizado como recurso novamente.

(149) Levanta-se a gen- | te pela volta das 8 horas, toma o seu café, mas um | café, compadre, todo adubado com milho, e outras coi- | sitas mais, coisa boa; lê o Correio Paulistano, faz o seu | toilette, isto é, lava o rosto, pentea-se, calça as chine- | la, veste a ceroula, a calça, o casaco, etc., fuma o seu | charutinho; e assim chega até as 10 horas, que é a hora $\mid$ do almoço, já se sabe, coisa fina, carne QUASI sempre de | boi pesteado, dizem que está reconhecida que é mais | saborosa, assim como a carne de dois e tres dias, por | que fica mais macia; não sabia desta, compadre, pois vá aprendendo, que muito tem que aprender. (Carta de Leitor, seção "a pedido", 1864, séc. XIX)

A carta em questão - exemplo (149) - foi inteira escrita com o objetivo de relatar a seu compadre a respeito do local que havia visitado, o qual não é identificado ao longo da mesma. O escrevente apresenta apenas elogios e toda informação intenciona exaltar a experiência por ele vivida e a qualidade de vida dos habitantes do local. A carne de boi pesteado, segundo o escrevente, seria mais saborosa e seria servida na maioria das vezes. A aproximação criada por quasi ao advérbio sempre destaca a qualidade das refeições, ao mesmo tempo em que indica que não era servido sempre o mesmo tipo de carne, o que não contribuiria para a exaltação do local realizada pelo escrevente.

(150) Eu lhe digo, pelo que eu quero a esse legumezito era | capaz até de pol-o n'um throno, mas com esta guerra | estão todos muito agarrados e a gente anda escorrida | de bolsa e não póde fazer africas nem proezas. $\|$ Dantes quatro vintens de feijão era QUASI um balaio, | agora é um 
fiapinho que nem os olhos enxergam. \| Ora isto assim não se póde mesmo aturar. (Carta de Leitor, seção "a pedido", 1865, séc. XIX)

Ao afirmar que antes quatro vinténs de feijão era quasi um balaio $^{156}$, o efeito permite criar um intenso contraste com fiapinho que nem os olhos enxergam, tornando, assim, bastante evidente a grande desvalorização que a moeda teria sofrido. Segundo o escrevente, anteriormente, quatro vinténs permitiriam comprar um balaio praticamente cheio de feijão, entretanto, no momento de seu discurso essa realidade seria diferente devido à crise econômica que teria se instaurado em virtude da guerra por ele mencionada. Quasi um balaio, assim como um balaio de, seria, portanto, uma locução quantificadora. Apesar disso, não foi possível classificá-la junto a outras locuções quantificadoras no padrão menos subjetivo, uma vez que o caráter da expressão um balaio de é bem mais subjetivo do que os dos numerais constituintes das locuções quantificadoras classificadas anteriormente. Assim, a atuação da construção quase acaba por ser, também, mais subjetiva, ao promover a aproximação a uma expressão já menos exata.

(151) Vivemos num mundo dinâmico, onde as tecnologias de QUASE todos os setores da sociedade, se renovam constantemente. (FUVEST, 2004, Redações dissertativas, séc. XXI)

(152) O mundo em que vivemos existem inúmeras fronteiras, seja entre países, regiões, estado ou até mesmo em pensamento e psicológico, em fim, em QUASE todos os cantos tem sempre uma fronteira. (FUVEST, 2009, Redações dissertativas, séc. XXI)

(153) Muitos casos são sempre muito comentados sobre as grandes instituições de ensino, como vandalismo e violência, mas em QUASE todos quem realmente deveria receber a culpa e a punição sai livre de qualquer acusação e apenas as instituições tem que arcar com os prejuízos e a má reputação. (FUVEST, 2010, Redações dissertativas, séc. $\mathrm{XXI})$

Em (151), ao mesmo tempo em que apresenta como argumento a favor da dinamicidade do mundo a ideia de que os setores da sociedade se renovam constantemente, o candidato emprega a palavra todos para enfatizar o caráter

\footnotetext{
${ }^{156}$ De origem imprecisa, a palavra "balaio" designaria um cesto de palha, geralmente bastante grande. $<$ http://www.dicionarioweb.com.br/pugillo.html $>$
} 
generalizado do fenômeno citado e a construção quase para preservar sua face, pois seria uma afirmação categórica - todos os setores da sociedade se renovam constantemente - a qual poderia ser contestada por outros indivíduos. Já em (152) e em (153), o traço de indefinição é mais forte. Apesar de ter apresentado anteriormente exemplos de onde poderíamos, segundo o candidato, encontrar fronteiras - entre países, regiões, estado, etc. - a expressão todos os cantos é mais indefinida do que quantificadora. A indefinição dessa expressão a torna muito abrangente e, provavelmente, teria sido essa a motivação do candidato a utilizar quase. $\mathrm{O}$ mesmo ocorre no exemplo seguinte, em que o escrevente introduz a questão já de forma indefinida ao utilizar muitos casos. Não nos é apresentada uma definição melhor para os casos aos quais o candidato estaria se referindo, sabemos apenas que estão relacionados a vandalismo e violência. No trecho seguinte - mas em QUASE todos quem realmente deveria receber a culpa e a punição sai livre de qualquer acusação - no qual o candidato insiste em não esclarecer a respeito dos referidos casos, a imprecisão de informações se intensifica com o emprego de quase, construção que impede uma afirmação categórica, a qual ocorreria devido à polaridade altamente positiva da palavra todos.

(154) Como foi o caso do Império Romano, que conquistou QUASE toda a Europa, espalhando sua cultura (Elenismo) quando conquistou a Grécia. (FUVEST, 2004, Redações dissertativas, séc. XXI)

Diferentemente do que ocorre nos dados anteriores, nos quais é sinalizada uma aproximação a um conjunto de elementos e é processada uma seleção desse conjunto ${ }^{157}$, temos, no caso do escopo toda no exemplo (154), outro mecanismo em atuação: a seleção de parte de uma "massa". Em muitos exemplos, essa corresponderá a um território, como é o caso do exemplo anterior, no qual parte do território da Europa é selecionada através do emprego da construção quase, atuante como um aproximativo à totalidade desse território, ou seja, selecionando a maior parte do mesmo.

\footnotetext{
157 Nas ocorrências quase todos os setores da sociedade; erão quasi todos paulistas; quasi todos procurarão segurança, podemos observar um mecanismo de restrição que atua sob a totalidade dos elementos de um conjunto, selecionando não todos, mas a maioria desses elementos.
} 
(155) (...) o mundo está cada vez mais individualista, as pessoas vivem o presente a todo custo e maneira, destroem a natureza, os recursos naturais, travam guerras por QUASE tudo, pelo poder, por territórios, pelo simples prazer de destruir, enfim, criam situações extremamente adversas e até particulares, mas que na realidade afetam a todos. (FUVEST, 2007, Redações dissertativas, séc. XXI)

(156) Percebe-se nos dias de hoje uma alta tecnologia de serviços na área de comunicação, voltada para fazermos QUASE tudo de dentro de nossas próprias residências, vejamos que o computador nos dar a internet, onde podemos navegar e conhecermos várias pessoas de diferentes lugares, fazendo assim amigos. (FUVEST, 2007, Redações dissertativas, séc. XXI)

(157) Pela Internet a pessoa pode fazer QUASE tudo, administrar o seu dinheiro, conversar com os amigos, fazer compras e outras coisas sem sair do conforto de sua casa. (FUVEST, 2008, Redações dissertativas, séc. XXI)

A imprecisão do escopo é maior nesses casos - (155) a (157) - o que leva os escreventes a considerarem necessária a apresentação de exemplificações dos conceitos aos quais estariam se referindo: pelo poder, por territórios, pelo simples prazer de destruir; podemos navegar e conhecermos várias pessoas de diferentes lugares; administrar o seu dinheiro, conversar com os amigos, fazer compras e outras coisas.

b) ênfase na prototipia desconstruída pelo escrevente: mobilizam-se para esse efeito partículas descentralizadoras de prototipia, o que produz uma interpretação decorrente de deslizamento categorial de uma construção. O que está sendo tomado como escopo, nesses casos, é o valor categórico em si, com vistas a produzir efeito focalizador da prototipia a que se visa defender.

b.1. com escopo adverbial de polaridade altamente positiva: o processo aqui envolvido é, novamente, o de aproximação a um grau dentro de uma escala de graus de modalidade.

(158) No limite termodinâmico foi provado que, em um intervalo de tempo finito as trajetórias convergem QUASE certamente para uma trajetória determinística, dada por uma equação diferencial de primeira ordem. (INSTITUTO DE MATEMÁTICA E ESTATÍSTICA, 2011, Resumos de teses, séc. XXI) 
(159) Al-Farabi escreveu a Cidade excelente já na maturidade, construindo-a QUASE de modo aforístico. (FACULDADE DE FILOSOFIA, LETRAS E CIÊNCIAS HUMANAS, 2010, Resumos de teses, séc. XXI)

Dois são os processos envolvidos na atuação da construção quase sob os itens nos dados (158) e (159). Por um lado, a polaridade negativa é atribuída e, portanto, a face do escrevente é preservada, pois a construção em questão impede que haja comprometimento por parte do mesmo, o que, nesses casos, é necessário, uma vez que se trata de palavras, as quais, devido à polaridade altamente positiva, levariam a uma afirmação categórica. Por outro lado, os conceitos pretendidos por esses advérbios são transmitidos. Ao se deparar com essas palavras, o leitor acessa os frames a elas relacionados e as impressões deixadas pelas mesmas marcam a conceptualização construída durante o discurso. Frente ao advérbio certamente no exemplo (158), o leitor constrói, apesar da presença de quase, uma forte ideia de que, em um intervalo de tempo finito, as trajetórias convergem para uma trajetória determinística, ainda que esse evento não corresponda a uma certeza absoluta. O mesmo ocorre nos outros casos desse subpadrão.

b.2. com escopo adjetival de polaridade altamente positiva: como no caso dos escopos de base adverbial, temos, também aqui, a atuação do processo de aproximação a determinado grau constituinte de uma escala de graus de modalidade.

(160) De meado do anno passado pa- | ra cá duas ou tres viagens tenho feito, e nada | de concertos, e a estrada arruinando se cada vez $\mid$ mais, de maneira que está hoje QUASI intrasitavel. Senhor Redactor, eu sou paulista, e gosto de ver | os meus patricios em alguns empregos, e merecen- | do frequentes, e pomposos encomios; mas se em | [corroído] | no, e os miseros tropeiros, alem de immensos | incommodos, soffrem perdas, estragando os ani- $\mid$ maes, que tão caro lhes custa, e com que tan| to concorrem para a renda publica, então ou | paulista, ou fluminense, ou bahiano, com tanto que / trate mais em estradas, do que em politica. (Carta de Leitor, seção “correspondências”, 1841, séc. XIX)

Endereçando a carta aos redatores do jornal em questão, o leitor registra sua reclamação a respeito do péssimo estado em que se encontra uma das estradas de seu Estado, solicitando que reparos sejam feitos e que essas sejam privilegiadas. A 
utilização de um adjetivo de polaridade altamente positiva - intransitável - vem a contribuir para o protesto do escrevente, uma vez que evidencia a gravidade da má conservação da estrada. Fica claro que ainda é possível transitar pela mesma, o que exige o emprego da construção quase, mas que é provável que, em pouco tempo quase promove a maior aproximação possível - esta se torne intransitável. Os processos envolvidos, nesse e nos exemplos a seguir, são os mesmos indicados anteriormente no caso dos advérbios de polaridade altamente positiva: a face do escrevente é preservada, pois quase impede que haja comprometimento por parte do mesmo e, por outro lado, os conceitos pretendidos por esses adjetivos são transmitidos, os frames a eles relacionados são acessados pelo leitor. Castilho (2010:564) propõe a classificação de "advérbio qualificador delimitador aproximador" para quase e concordamos com o autor ao afirmar que:

Ao comprometer a prototipicidade da classe-escopo, os aproximadores desempenham na esfera do discurso o importante papel de "controlar" a recepção dos significados. Por meio deles, passamos ao nosso intelector instruções sobre como ele deve acionar os mecanismos linguísticos de significação.

Os mecanismos linguísticos de significação dos escopos são acionados pelos interlocutores, entretanto, quase "controla" o modo como deverão ser recepcionados. Assim como quase, a palavra almost, na língua inglesa, também possibilita o acesso ao frame transmitido por seu escopo sem que haja comprometimento envolvido. Gerrevinck \& Hoop (2007), os quais trabalharam com almost, postulam que:

We have seen that especially in those cases where a proposition $p$ leads to conclusion $\mathrm{q}$ and proposition $\mathrm{p}$ is not (entirely) true in the real world, a speaker can use a formulation with almost to try and convince the hearer still that conclusion $\mathrm{q}$ is the case, without having to tell a lie. Formulations with almost surfaced as the optimal output for achieving the speaker's goal ${ }^{158}$.

\footnotetext{
${ }^{158}$ Nós temos visto que, especialmente naqueles casos em que a proposição $p$ conduz à conclusão $q$ e a proposição $p$ não é (inteiramente) verdadeira no mundo real, um falante pode usar uma formulação com almost (quase) para tentar convencer o ouvinte de que é o caso da conclusão $q$, sem ter de contar uma mentira. Formulações com almost (quase) surgiram como a saída ideal para alcançar os objetivos do falante.
} 
Mecanismo semelhante irá operar nas funcionalidades assumidas pela construção quase, a qual permitirá ao escrevente alcançar seu objetivo sem expor sua face perante uma proposição que possa soar como falsa.

(161) Ora realmente felicissimo compadre, uma vidinha | destas é para chegar com certeza á idade do defunto | Mathuzalen, que nem eu, nem o compadre conhece- | mos. || É verdade que o anasphaltissimo compadre por isso | mesmo anda no mundo da lua, a respeito de progresso | progressante não encherga um palmo adiante do nariz; | e para de todo não ficar obtuso é mister que eu o vá, | com estas minhas cartas burnindo, e tirando-o do es- | tado QUASI natural em que se acha. || Tenha paciencia, compadre, Deus me defenda de dei- | xal-o (o compadre, não a Deus) fazer figura ridicula; | tenha paciencia, heide dezabuzal-o. (Carta de Leitor, seção "a pedido", 1864, séc. XIX)

(162) Uma nuvem de pó e fumo levantou-se aos ares nar- | rando a mil olhos que de varios pontos da cidade acom- | panhavão os carros uma desgraça QUASI certa! (Carta de Leitor, seção "comunicados", 1865, séc. XIX)

(163) Muito estimarei que ao receber estas mal traçadas | regras, se ache já QUASI boa do seu romatismo. (Carta de Leitor, seção "a pedido", 1865, séc. XIX)

(164) Recebi as suas amadas regras, que passo a res- | ponder. || A minha perna já está QUASI boa do romatismo; pois | já ando por todo o quintal, e pretendo na sexta-feira / ir a missa do Senhor dos Passos. (Carta de Leitor, seção "a pedido", 1865, séc. XIX)

(165) O relógio QUASE líquido de Dalí jamais se desfará por completo, permanecendo o tempo como um conceito abstrato, impalpável, mas sempre presente na realidade concreta. (FUVEST, 2004, Redações dissertativas, séc. XXI)

A presença do aproximativo quase é obrigatória no exemplo (165) acima, uma vez que é feita referência a um quadro famoso do pintor Salvador Dalí - "A Persistência da Memória" - e o leitor, portanto, tem conhecimento de que não se trata de um relógio líquido, mas, sim, apenas derretido. A preservação da face é necessária, pois a afirmação pode ser por outros contestada, o que também é percebido nos exemplos (166) e (167) abaixo. 
(166) Enquanto Hobesbaum se debruça sobre o tempo passado, Heberto Linhares tem do tempo uma visão imediatista, QUASE infantil: o tempo é hoje, o momento é já. (FUVEST, 2004, Redações dissertativas, séc. $\mathrm{XXI})$

(167) Podemos tomar como nota a ocupação da reitoria em 2007, um ato que demonstra um espírito de reivindicação dos alunos para algumas situações, mas tão ocupação causou uma paralização QUASE geral das aulas em torno do campus. Causando a estagnação do bem que faz a universidade ser o que é. (FUVEST, 2010, Redações dissertativas, séc. $\mathrm{XXI})$

Como verificaremos nos dados (168) a (172) abaixo, o emprego da construção quase é, novamente, obrigatório, uma vez que os conceitos sinalizados pelos escopos são irreais. Catracas, mesmo que não concretas, como aquelas construídas pela mídia, jamais serão totalmente imperceptíveis; profissionais não poderão ser perfeitos; é possível avaliar pessoas por seus valores morais.

(168) Mas, além dessas catracas visíveis, existem outras. Elas são QUASE imperceptíveis, mas alcançam uma profundidade maior. A mídia exerce o papel de formadora de opinião, criando hábitos, tendências e estereótipos, responsáveis pelo preconceito. (FUVEST, 2005, Redações dissertativas, séc. XXI)

(169) Uma das mais conceituadas instituições de ensino do Brasil e do mundo, onde o ensino é passado plenamente, com exemplar organização, excelente infra-estrutura por profissionais QUASE perfeitos. (FUVEST, 2010, Redações dissertativas, séc. XXI)

(170) Mas, na realidade o que vemos é uma divisão gigantesca de classes, onde é QUASE impossível avaliar as pessoas por seus valores morais e não pelo lugar de onde veio ou o nome do pai ou a marca do tênis, onde o seu exterior conta muito mais, do que o interior, coisas como imaginação, visão da realidade e do futuro, aptidão e até mesmo conceitos são menos relevantes. (FUVEST, 2010, Redações dissertativas, séc. XXI)

(171) Talvez o maior problema seja justamente a erosão de critérios de julgamento que a informação abundante parece propiciar - como se nada houvesse de estável ou confiável, ou fixo. Porém, a Ciência é ainda - e seguirá sendo - um ( sic) do conhecimento. Da mesma forma como os Valores Humanos Universais são de uma invariância cravada na própria natureza humana. Além disso, a informação (QUASE?) infinita ajuda a demolir barreiras, a erodir visões etnocêntricas e egoístas, a criar 
consensos e a construir um mundo mais justo. (FUVEST, 2008, Redações dissertativas, séc. XXI)

(172) No passado, as empresas claramente optavam pelos plásticos chamados de termofixos, que hoje estão QUASE esquecidos ou obsoletos (principalmente devido aos processamentos mais custosos e/ou mais lentos). (ESCOLA POLITÉCNICA, 2006, Resumos de teses, séc. $\mathrm{XXI})$

b.3. com escopo conjuncional de base comparativa como: quase funciona como item de polaridade negativa que quebra uma comparação categórica sinalizada por seus escopos. Assim, os termos em questão podem ser comparados, porém não de forma perfeita.

(173) A valorização dos minutos e segundos (sic) a turbulências, a que se contrapõem calorosamente, visões que enaltecem outros períodos: o passado e o futuro. Neles, que têm duração muito maior do que o instante, alojam-se o consolo para a onipresente sensação do insólito e a esperança da solução para os problemas do momento em que vivemos. Duas antíteses que combatem a tese, do presente ferrenhamente, QUASE como se fossem excludentes. (FUVEST, 2004, Redações dissertativas, séc. XXI)

O exemplo (173) se destaca dos outros desse subpadrão - ilustrados pelo exemplo (174) a seguir - por sua maior imprecisão. A presença muito acentuada do traço irrealis nos parece ser o fator responsável por esse caráter tão impreciso. Além de presente em quase, esse traço aparece novamente no uso do modo subjuntivo em fossem, quando uma situação hipotética é estabelecida: como se fossem excludentes. A ideia de que as antíteses seriam excludentes entre si é negada, pelo escrevente, portanto, duas vezes: pelo emprego de quase e pelo uso do modo subjuntivo.

(174) O estudo da acústica de salas data do início do século XX e, até então, esta atividade era vista QUASE como uma arte e não como ciência. (INSTITUTO DE MATEMÁTICA E ESTÁTICA, 2008, Resumos de teses, séc. XXI)

\section{b.4. com escopo verbal que produz um efeito irreversível em sua polaridade}

altamente positiva: nestes dados, quase funciona como aproximativo à categoria de processo. O conceito por trás de seu emprego é o de iminência, o que o aproximaria de 
um marcador aspectual, sem o ser de fato. Quase quebra a categoricidade dos fatos codificados pelos verbos, impedindo que o efeito irreversível se produza.

(175) Apenas chegou-nos à noticia o funesto acontecimento praticado n'esta Cidade em a noite de 11 do corrente, QUASI succumbimos pelo excesso do pezar; e as circunstancias do facto, quaes nos referirão, presentes á nossa imaginação, não permittuão (sic) diminuir se a energia d'estes sentimentos generosos, que são communs a todo o cidadão amigo da humanidade, da Patria, e da restricta observancia das leis. (...) Entretanto se a causa indirecta do assassinio foi, como dizem, a publicação de uma carta, que inserimos em nosso ultimo número, sem duvida folgarão com isto os desgostosos das Instituiçõens Liberaes; mas consola-nos a lisongeira idea de que todo o homem são, despido de prejuizos, e amante da prosperidade Nacional, sentindo quam preciosa foi sempre a propagação das luzes, e a livre emissão do pensamento em materias politicas ha-de convencer-se de que á falta de conhecimentos, e a immoralidade é que se deve tornar a culpa de qualquer máo resultado, que maliciozamente se queira attribuir á liberdade da Imprensa. (Carta de Redator, 1827, séc. XIX)

O trecho (175) foi retirado de uma carta redigida pelo redator do jornal a fim de esclarecer à população que a anterior publicação de uma carta, acusada de ter sido a causa indireta de um assassinato, nada tem a ver com o ocorrido e que não se deve atribuir à liberdade de imprensa - exaltada em "sentindo quam preciosa foi sempre a propagação das luzes" - o que é, na realidade, segundo o redator, culpa da falta de conhecimentos e da imoralidade. O objetivo central da referida carta é, portanto, promover a defesa do jornal. O tom emocional ao mencionar o assassinato é, dessa forma, importante para o redator, na medida em que é através dele que podem ser demonstrados à população os sentimentos de compaixão e solidariedade por parte dos profissionais do jornal frente ao acontecimento. É essa a intenção do escrevente em passagens como "quasi succumbimos pelo excesso do pezar"; "a energia d'estes sentimentos generosos, que são communs a todo o cidadão amigo da humanidade, da Patria”. A construção quasi permite ao redator valer-se de uma expressão que deixa clara a comoção dos profissionais - "succumbimos pelo excesso do pezar" - sem comprometer-se com um tom de exagero. Assim, a face do escrevente é preservada e, por outro lado, a intenção de comunicar o grande pesar sentido frente à notícia do assassinato, é alcançada. 
(176) Depois de cessar por um pouco essa abundante chuva, que $\mid$ desde o anno passado tem caido todos os | dias sem interrupção, quiz ver o estado da | varzea do Carmo, e se com effeito tinha- | se conseguido o fim d'esgotál-a, dirigi-me | até a chamada ponte do ferrão, que foi | entulhada, e vi que o pêso das aguas, que | não respeita grandes barreiras, quanto | mais ás fracas havia aberto o seu antigo | caminho, interrompendo QUASI a communi- | cação por aquelle lado causando um in- | commodo indisivel, não só aos habitantes | da Cidade, como aos lavradores, que não | podem condusir seus generos; e o mais é | que ja está assim há muito tempo!!! (Carta de Leitor, seção "correspondência", 1828 , séc. XIX)

Registrando queixa a respeito dos estragos provocados pelas fortes chuvas, o leitor relata o mau estado em que se encontra a "chamada ponte do ferrão", onde a água havia destruído barreiras, "interrompendo quasi a communi- | cação por aquelle lado". A gravidade da situação fica mais evidente quando o escrevente menciona as dificuldades vividas pelos habitantes e lavradores da cidade e o fato de estarem nessa condição já há um longo período. A iminência da interrupção da "communi- | cação por aquelle lado", ou seja, o fato de a ponte estar próxima de tornar-se intransitável, fortalece o protesto do leitor. $\mathrm{O}$ emprego da palavra quasi promove a maior aproximação possível a essa interrupção, sendo ela a responsável pela criação do efeito de iminência.

O mesmo se dá com o exemplo (177), já apresentado e retomado aqui, de resumos de teses:

(177) Verificou-se que a Margem Continental Brasileira apresenta características transicionais entre as águas frias ao sul e as águas quentes ao norte, apresentando grande concentração de espécies típicas de águas frias em sua porção sul. A influência dessas espécies decresce em direção ao norte, até QUASE desaparecer na região da Ilha de São Sebastião. (INSTITUTO OCEANOGRÁFICO, 2006, Resumos de teses, séc. XXI)

O movimento, o qual o autor pretende demonstrar, é o de decréscimo constante da influência das mencionadas espécies. É de se esperar que o ponto final desse movimento de decréscimo fosse o desaparecimento, entretanto, uma vez que o mesmo não é verificado, o autor recorre à indicação de que a situação identificada foi a mais próxima possível desse desaparecimento. 


\subsubsection{Usos intersubjetivos}

Nos exemplos prototipicamente intersubjetivos, nota-se a inferência, por parte do falante/escritor, da percepção ou compreensão que o ouvinte/leitor fará de sua mensagem, a partir de "pistas" socialmente estabelecidas e que, como veremos, poderão codificar sintaticamente a ação do autor-escrevente ao manipular as informações.

a) monitoramento da percepção interpretativa do interlocutor: mobilizam-se para esse efeito partículas que codificam um grau intermediário de polaridade negativa total sinalizada pelos escopos adverbiais, preposicionais e pronominais de caráter indefinido. Os advérbios não e nunca e o pronome indefinido nada - no caso das amostras de redações e dos resumos de teses - pelos pronomes adjetivos nenhum(a) e pela preposição sem - somente no caso das teses.

O escopo da negação é a própria partícula negativa, que deve ser interpretada como um grau menor de negação nos casos em que esse padrão é empregado. Observemos que, em muitas ocorrências, a partícula quase atua funcionalmente como elemento compositivo de uma locução quantificadora. Verhagen (2005) postula que o recurso da negação deva ser compreendido como a coordenação entre sujeitos cognitivos, ou seja, entre conceptualizadores, e que, portanto, trata-se de um mecanismo intersubjetivo. $\mathrm{O}$ processo atuante, nesses casos, vincula-se à aproximação ao polo de uma escala constituída por graus de modalidade, cujos polos seriam: sim e não; sempre e nunca; etc.

(178) Por outro lado, a história do Brasil já começou com interesses, escreveram-a de acordo com a visão eurocêntrica e esqueceram da cultura que havia aqui, o índio, este mesmo índio que logo depois foi obrigado a trabalhar a força em sua pátria, o mesmo índio que QUASE não participa da nossa história. (FUVEST, 2004, Redações dissertativas, séc. XXI)

(179) No entanto, a liberdade proporcionada pelos meios digitais frequentemente torna a qualidade e a veracidade de seu conteúdo questionáveis. Muitas falsas notícias são distribuídas e fomentadas via rede, inclusive por "sites" conceituados. Fotos e vídeos pessoais podem ser disponibilizados contra a vontade de seus donos, QUASE não há 
respeito aos direitos autorais e falta segurança para as máquinas dos conectados à Internet. (FUVEST, 2008, Redações dissertativas, séc. XXI)

(180) O nosso mundo digital ele é bom mais temos que separar as coisas, usar o computador para estudar, estar sempre atualizado, mas não no orkut, mas sim nos sites das melhores faculdades ou em pesquisas. Poderiam colocar mais assuntos de faculdade falar mais nas rádios, televisões sobre livros, cursos, etc, construir bibliotecas as pessoas QUASE não tem apoio dos colegas da família então levar tudo isso até ela. (FUVEST, 2008, Redações dissertativas, séc. XXI)

(181) E também os adultos que assistem televisão, novelas que representam a vida, e QUASE não saem de casa, como se dependessem das informações e histórias transmitidas para sobreviver. (FUVEST, 2010, Redações dissertativas, séc. XXI)

(182) Sem ter seus direitos assegurados, estes migrantes precisam encontrar maneiras de "se virar" na cidade para tentar garantir algumas condições básicas de vida e, quem sabe, alguns destes direitos. Assim, inventam táticas astuciosas para enfrentar a situação de pobreza, sendo uma delas a busca por redes sociais de apoio. Os equipamentos públicos QUASE não aparecem nestas procuras por redes sociais. As rendas oriundas de alguns programas governamentais, quando existem, são pouco divulgadas, exigindo que enfrentem grandes adversidades para consegui-las. (INSTITUTO DE PSICOLOGIA, 2013, Resumos de teses, séc. XXI)

(183) Estudar o tempo passado, histórico, significa entender como nosso ancestrais viveram, de que forma eles lidaram com as adversidades de sua época e aprender com eles. Infelizmente, QUASE nunca temos uma versão neutra e objetiva dos acontecimentos. A história é registrada do ponto de vista dos dominantes, nunca dos dominados. (FUVEST, 2004, Redações dissertativas, séc. XXI)

Em (179), quase, topicalizado na segunda sentença, toma esta inteira como escopo. Isso não ocorre nos outros exemplos, parecendo, então, formalmente diferentes desse dado. Em (178), aparece entre sujeito - pronome relativo que, referente a $o$ mesmo índio - e verbo. O escopo é não participa. No dado (180), aparece novamente entre sujeito (as pessoas) e verbo, sendo não tem o escopo. No exemplo (181), o sujeito não está diretamente à esquerda de quase, sendo oculto e expresso na oração anterior (os adultos). O escopo mantém-se constituído por verbo: não saem. Já em (183), a construção é de caráter temporal - o escopo é nunca temos. Nesses dados, a intenção do 
candidato ao empregar quase é proteger sua face, pois, em todos os casos, a afirmação em questão pode ser contestada por outros.

Poderíamos estabelecer, a partir desses dados, um cálculo matemático:

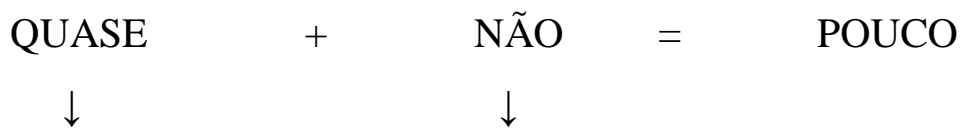

polaridade parcial negativa polaridade global negativa

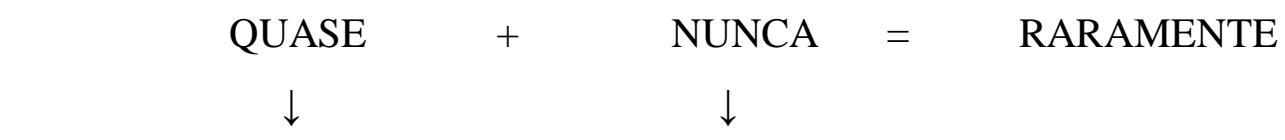

polaridade parcial negativa polaridade global negativa

Nos casos (184) a (187) abaixo, a partícula quase sinaliza gradação de intensidade, regressivamente, podendo também ser classificada funcionalmente como elemento compositivo de uma locução quantificadora, tal como demonstramos, antes, na descrição dos usos contidos nos resumos de teses:

(184) Apesar do auxílio prestado, pouco ou QUASE nada é realizado com a finalidade de erradicar definitivamente o problema. (FUVEST, 2011, Redações dissertativas, séc. XXI)

(185) O cromo, na forma de óxi-hidróxido, se manteve precipitado junto às partículas do solo; o cobre, pouco ou QUASE nada se alterou. (INSTITUTO DE GEOCIÊNCIAS, 2007, Resumos de teses, séc. XXI)

(186) Durante este período, os fluxos de material orgânico particulado (MOP) estão entre os mais elevados do oceano, enquanto que pouco ou QUASE nada é exportado no período coberto por gelo. (INSTITUTO OCEANOGRÁFICO, 2007, Resumos de teses, séc. XXI)

(187) Enquanto que pacientes submetidos à técnica de BELL 12 tiveram pouco ou QUASE nenhum desconforto. (FACULDADE DE ODONTOLOGIA, 2006, Resumos de teses, séc. XXI)

\section{Dados à parte}

A seguir, dispusemos os dados que não puderam ser encaixados em nenhuma das classificações acima. 
(188) outras formas de dispersão, como frústulas e pólipos desprendidos, podem fixar-se e crescer em QUASE qualquer animal macroscópico do bentos marinho. (INSTITUTO DE BIOCIÊNCIAS, 2007, Resumos de teses, séc. XXI)

Neste caso, temos o rompimento da categoricidade de uma generalização. É um exemplo de emprego subjetivo.

(189) SDS-PAGE mostraram que subunidades HEX 70b permanecem acumuladas em grande quantidade na hemolinfa pelo menos até a fase de pupa de pigmentação cuticular intermediária, QUASE ao final do estágio pupal, e então diminuem progressivamente. (FACULDADE DE FILOSOFIA, CIÊNCIAS E LETRAS DE RIBEIRÃO PRETO, 2006, Resumos de teses, séc. XXI)

Temos um caso de imprecisão temporal em (189), uma vez que o escopo (ao final do estágio pupal) ganha imprecisão. Em virtude de sua maior abstratização, no entanto, não o situamos junto aos outros exemplos da categoria tempo e o consideramos subjetivo.

(190) O seu [o da sociedade portuguesa] ingresso tardio no coro europeu apenas a partir dos grandes descobrimentos marítimos determinou um tipo de sociedade que se desenvolveu, em alguns sentidos, QUASE à margem das outras nações europeias e constitui-se uma zona de transição por ser uma das pontes pelas quais a Europa comunica-se com outros mundos. (FACULDADE DE FILOSOFIA, LETRAS E CIÊNCIAS HUMANAS, 2011, Resumos de teses, séc. XXI)

Apesar de constituir-se uma locução adverbial de lugar, o exemplo (190) não pôde ser encaixado junto às outras, também devido a seu caráter mais abstrato e, neste caso, subjetivo. Segundo o autor, a sociedade portuguesa não teria se desenvolvido da mesma forma que as outras nações europeias.

Apresentados os padrões funcionais de quase identificados, retomamos Verhagen (2005), que, como já citamos, postula que aspectos semânticos e sintáticos podem ser entendidos a partir da compreensão de mecanismos e operações cognitivas realizadas pelo falante/escritor. Retomamos, portanto, a análise dos mecanismos que pudemos identificar como atuantes nos dados levantados. 
De acordo com a atuação do princípio de iconicidade, verificamos os seguintes mecanismos:

(i) subprincípio de quantidade e distância: em que a construção quase que toma como escopo pronomes (mecanismo de partitude), adjetivos, advérbios, locuções adverbiais (mecanismo de aproximação ao polo de uma escala de graus) e substantivos. No caso deste último, imaginamos que o mecanismo atuante fosse outro, já demonstrado na análise dos padrões funcionais: o de aproximação a uma esfera, constituída por um conceito;

(ii) subprincípio de distância: casos em que quase toma substantivos como escopo (aproximação a uma esfera).

Como demonstramos, todos os dados eram subjetivos, tendo sido, portanto, divididos em menos subjetivos, subjetivos e intersubjetivos. Dentre os dados menos subjetivos, estabelecemos três classificações de padrões funcionais, levando-se em consideração o escopo da construção quase:

(i) advérbio ou locução adverbial de lugar (em que quase promove localização imprecisa);

(ii) números cardinais, fracionários, multiplicativos ou em forma de porcentagem (no qual o valor impreciso codificado confere amplitude à informação) e o adjetivo nulo (em que a proximidade a "zero" é enfatizada);

(iii) advérbio ou locução adverbial de tempo (no qual a indicação temporal imprecisa confere, na maioria dos casos, amplitude ao dado).

Nos três padrões funcionais menos subjetivos elencados, identificamos, como mecanismo atuante no emprego de quase, o de aproximação ao polo de uma escala, no caso dos números, uma escala de quantificação e, nos outros casos, de graus ${ }^{159}$.

Os dados subjetivos propriamente ditos, por sua vez, foram por nós divididos em cinco padrões funcionais e os mecanismos atuantes foram explanados do seguinte modo:

${ }^{159}$ Castilho (2010:560) fala em "advérbios qualificadores graduadores atenuadores". Acreditamos que seja este o caso de quase em funções como essa. 
(i) itens de polaridade altamente positiva, já dotados de imprecisão antes da atuação de quase:

- todos (as): o mecanismo atuante é o de seleção da maioria dos membros de um conjunto (quantificação);

- todo (a): temos, nesses casos, a seleção da maior parte de uma "massa" (partitude);

- totalidade: a depender do caso, temos a atuação de um dos mecanismos acima descritos;

- total e sempre: temos, novamente, a aproximação ao polo de uma escala de graus;

(ii) itens de polaridade altamente positiva, de base adjetival ou adverbial: a escala de graus, também aqui presente, consiste um mecanismo derivado da quantificação: a qualificação;

(iii) quebra de uma comparação categórica (escopo como);

(iv) bloqueio do efeito irreversível de um escopo verbal;

Por fim, nos dados intersubjetivos, verificamos a codificação do grau intermediário de uma polaridade negativa total:

- não; nunca: atuação do mecanismo veiculado à escala de graus;

- nada; nenhum (a); sem: envolvendo a quantificação, temos, novamente, o mecanismo referente à escala

Referentes ao mecanismo de aproximação ao polo de uma escala, temos dois processos envolvidos, sendo que, hipotetizamos, um originou o outro: escala de quantificação e escala de graus, relacionada à qualificação. Outros dois processos semelhantes entre si seriam o de seleção da maioria dos membros de um conjunto, vinculado à quantificação, e o de seleção da maior parte de uma "massa", relativo à ideia de partitude. A aproximação ao que denominamos de esfera - englobamento de 
um conceito - parece-nos um mecanismo mais complexo. Atuando de outra forma, o traço irrealis de quase leva à quebra de uma comparação categórica e ao bloqueio do efeito irreversível codificado por um escopo verbal.

A respeito do mecanismo que envolve a noção de escala, Traugott (2010:29) afirmou que uma mudança de significados que são usados para avaliar valorativamente não só mais ou menos quantidade, mas também mais ou menos qualidade, sempre envolve subjetificação, pois, de acordo com a autora, as inferências avaliativas provocadas são semanticizadas como parte do significado do item que passa a indexar escalaridade.

Depois de ter se fixado como item codificador de aproximação bastante rente talvez, a mais rente possível - a quantificações, hipotetizamos que o conceito de posicionamento de um valor em uma escala tenha se semanticizado como parte do significado de quase, que passou a codificar também valores avaliativos, transformando-se em um modificador de graus. Esses valores poderiam ser distribuídos nas seguintes escalas de abstratização sugeridas, obedecendo a pressupostos teóricos da cognição (em seus princípios da evolução ontogênica) e da gramaticalização (em seus princípios de complexidade gramatical), os quais admitem que quantidade é categoria mais básica do que qualidade e que parte é mais básica que a compreensão do todo:

a) Hipótese unilinear de gramaticalização

quantificação (escala e seleção de membros) > partitude > qualificação > esfera

b) Hipótese poligramaticalização

quantidade $>$ parte $>$ soma $>$ totalidade

qualidade > abrangência

Ao funcionar como advérbio e como adjetivo, a construção quase, a depender do escopo, codifica qualidade, uma categoria cognitiva abstrata, a qual tem relação direta com uma ação muito complexa e abstrata de qualificar informações e a qual demanda muito pouco de conhecimento externo, pois uma configuração construcional abstrata guia todo o aparato cognitivo a funcionar com o que de mais básico possui em seu computador orgânico, ou seja, a mente: o processo analógico. O fato é que todo indivíduo, desde cedo, estabelece comparações, o que lhe permite reconhecer não somente um processo útil para comunicar ideias e avaliações, mas, acima de tudo, lhe 
garante a mobilização de um mecanismo ativo para se aprender qualquer coisa, inclusive língua.

\section{Contabilização linguística}

Devido às diferenças que identificamos como estruturais (quantidade de palavras, extensão do texto), as quais se apresentam recorrentes nos gêneros textuais constituintes dos corpora analisados - cartas de leitores e cartas de redatores; redações dissertativas de candidatos ao vestibular; resumos de teses - não nos foi possível, num primeiro momento, perceber diferenças de usos.

A partir de uma contabilização baseada na concorrência de usos e a partir da leitura de Coracini (1991) a respeito dos aspectos particulares envolvidos na modalidade em textos científicos - o caso dos resumos de teses - verificamos, no entanto, que havia razões para que essa amostra incluísse um maior número de ocorrências. Os autores precisavam criar uma expectativa sobre o que falariam, mas, ao mesmo tempo, precisavam garantir que seus resultados, nem sempre tão abrangentes, pudessem ser questionados por outros pesquisadores. Segundo Coracini (1991), o papel desempenhado pela modalidade ${ }^{160}$ no discurso científico envolve a intenção de camuflar a "origem enunciativa", demonstrando que, "aparentemente, é o enunciado quem diz o fato que se apresenta e não o sujeito-enunciador" (CORACINI, 1991:123). O que verificamos na descrição dos padrões funcionais de quase está em conformidade com as ideias defendidas por esse autor. A intenção de proteger-se de possíveis contestações, por nós apontada na análise dos dados, é tratada por Coracini, que considera a modalidade no discurso científico como decorrente, justamente, da antecipação por parte do locutor de possíveis refutações (contra- argumentos, contraprovas) a asserções ou conclusões baseadas nos dados, na teoria ou metodologia adotadas.

A ampla amostra (1104 ocorrências de quase) constituída a partir dos resumos de teses exigiu a representação das frequências de cada classificação também em forma

\footnotetext{
${ }^{160}$ Definida por Coracini (1991:121) como "o modo como o pesquisador assume, de um lado, a sua pesquisa e, do outro, o seu discurso, manifestando a sua presença ou se distanciando, conforme suas intenções e o esquema convencional a que precisa obedecer".
} 
de porcentagem. Sendo assim, essa parece ser a amostra mais interessante para uma observação de como a regra variável se consubstancia.

Devido ao reduzido número de ocorrências identificadas nas cartas de redatores e leitores e nas redações dissertativas, as ocorrências serão apresentadas em números absolutos.

Vejamos o resultado da tabulação desses dados:

\begin{tabular}{|l|c|}
\hline \multicolumn{1}{|c|}{ PADRÕES } & CARTAS DE LEITORES \\
\hline Menos subjetivos & 1 \\
\hline Quase todos (quantificação) & 3 \\
\hline Quase todo (partitude) & 1 \\
\hline Iminência & - \\
\hline Quase como (se) & 6 \\
\hline Escala & 2 \\
\hline Intersubjetivos ${ }^{161}$ & \\
\hline
\end{tabular}

\begin{tabular}{|l|c|}
\hline \multicolumn{1}{|c|}{ PADRÕES } & CARTAS DE REDATORES \\
\hline Menos subjetivos & 1 \\
\hline Quase todos (quantificação) & - \\
\hline Quase todo (partitude) & 1 \\
\hline Iminência & - \\
\hline Quase como (se) & - \\
\hline Escala & - \\
\hline Intersubjetivos & \\
\hline
\end{tabular}

\section{PADRÕES}

REDAÇÕES DISSERTATIVAS DE

${ }^{161}$ Entre os dados intersubjetivos de cada corpus, incluímos aqueles em que atuam os subprincípios de quantidade e de distância - ainda que, dentre esses dados, atue também, por exemplo, o mecanismo de aproximação a uma esfera ou de aproximação ao polo de uma escala - e os que tomam a negação como escopo. 


\begin{tabular}{|l|c|}
\hline & VESTIBULAR \\
\hline Menos subjetivos & 1 \\
\hline Quase todos (quantificação) & 6 \\
\hline Quase todo (partitude) & 1 \\
\hline Iminência & 1 \\
\hline Quase como (se) & 8 \\
\hline Escala & 15 \\
\hline Intersubjetivos & \\
\hline
\end{tabular}

\begin{tabular}{|l|c|}
\hline \multicolumn{1}{|c|}{ PADRÕES } & RESUMOS DE TESES \\
\hline Menos subjetivos & $14,76 \%(163)$ \\
\hline Quase todos (quantificação) & $19,47 \%(215)$ \\
\hline Quase todo (partitude) & $8,78 \%(97)$ \\
\hline Iminência & $1,54 \%(17)$ \\
\hline Quase como (se) & $0,36 \%(4)$ \\
\hline Escala & $38,49 \%(425)$ \\
\hline Intersubjetivos & $16,60 \%(183)$ \\
\hline
\end{tabular}

O número reduzido de ocorrências nas redações dissertativas se justifica pelo próprio propósito desse gênero, que pede assertividade em grau elevado e pouco espaço para a dúvida. Em relação às cartas, notamos uma quantidade um pouco maior de dados nas de leitores, os quais se sentiriam menos pressionados quanto ao emprego do que, imaginavam, ser uma linguagem formal. Os redatores, por sua vez, sentiriam, provavelmente, uma maior pressão por, em seu entendimento, terem a responsabilidade de atuarem como exemplos quanto ao emprego considerado correto da língua. Conclusões não podem ser feitas a partir de um número tão reduzido de dados, entretanto, podemos perceber, já nesses corpora, o contexto, o qual será observado na amostra de controle, sendo delineado: dados subjetivos e intersubjetivos prevalentes em 
detrimento dos menos subjetivos. O emprego mais abstratizado de quase fica evidente a partir da observação das frequências de ocorrências nos resumos de teses.

Assim, percebemos o processo de abstratização de quase, a partir do qual foram incorporados traços e funções deflagradores de muito do que quase que hoje revela, como refletimos no início deste capítulo. A atuação de princípios funcionalistas guiou as mudanças, como havíamos hipotetizado, e, apesar de distantes, de certa forma, quase e quase que mantêm-se vinculados pelo traço resiliente, que em ambos persiste, como verificamos: o traço irrealis. 


\section{Considerações finais}

Iniciamos esta dissertação com um plano de três capítulos. Esse plano foi superado pelas questões que foram se proliferando e que, naturalmente, exigiam decisões metodológicas. A importância de fazer o relato sobre esse plano de um futuro que não se concretizou demonstra o quanto a intenção de um falante e de um escrevente refletem-se sobre a forma de codificação.

No primeiro capítulo, teci reflexões derivadas de nossas leituras e embates teóricos nos campos da gramaticalização funcionalista e da cognição social. Antes que essa dissertação pudesse ser imaginada, já havia um ensaio de dois anos sobre construções de natureza pragmática similar. Referimo-nos às construções meio e meio que. Perguntamo-nos por que indivíduos em situações de alta assertividade lançariam mão de estratégias que soavam tão duvidosas e denunciadoras de incerteza sobre seu estatuto. Esse foi o início do novo percurso com as construções quase e quase que. Como professora, o interesse era reconhecer seu estatuto e as formas de abordagem pedagógica de elementos pouco centrais em classes de palavras. Como pesquisadora, o interesse era entender como uma mente fluida deixava escapar essa fluidez de raciocínio por meio de determinadas construções linguísticas.

Esses questionamentos conduziram-nos à decisão de uma posição teórica que favorecesse respostas plausíveis e adequadas. A perspectiva adotada foi a cognitivofuncional, mas não foi uma decisão fácil de encaixamento mental. A mente formada num padrão binário demanda energia enorme para lidar com a descontinuidade, com o uso fugaz, com as perguntas de respostas complexas. Com o auxílio da reflexão de Tomasello (1999, 2008), Croft (2009) e Givón (1995), alcançamos um patamar de discussão que colocava em diálogo as várias descobertas científicas de cognição e linguagem. Como já afirmamos antes, na introdução desta dissertação, tanto o diálogo convergente quanto o divergente propiciaram que forças agissem para dar suporte metodológico ao que pretendíamos.

Planejamos as amostras que seriam analisadas com base num único critério: alcançar as respostas pretendidas. Assim, decidimo-nos pelas redações dissertativas da Fuvest, que não se revelaram produtivas no emprego das construções estudadas. Precisávamos evidenciar que havia uma razão para esse baixo emprego. Para isso, 
necessitávamos de amostras de gêneros distintos, os quais nos fornecessem elementos para entender por que alguns jovens, em situação de alta formalidade escrita e dialogando sobre tema decidido pela instituição pública em que pleiteavam uma vaga de universitário, empregavam as construções sob análise da forma como empregavam. Outras amostras foram, então, selecionadas. E uma delas (resumos de teses) permitiu organizar as ideias e compreender as razões para o uso na primeira amostra. Enfim, apenas por meio da análise de outra amostra totalmente diferente pudemos compreender, efetivamente, a amostra em que o uso não pareceu produtivo. Essa decisão também nos dá pistas sobre como a mente humana funciona: a diferença de padrões (num processo comparativo ou analógico) motiva-nos à aprendizagem.

E lendo Pinker (2008[2007]), pudemos compreender que palavras não são apenas palavras. Mas, sim, carregam os contextos de usos e as histórias de usos. Indissociam-se dos usos a que já serviram no passado. Iniciamos, então, a delimitação histórica de nosso objeto de interesse, as construções quase e quase que. Essa viagem permitiu dialogar com gramáticos de vários momentos, recolhendo suas escolhas, decisões e rejeições também. Identificamos, assim, o que pudemos chamar de traço resiliente.

No capítulo IV, nossas decisões e escolhas foram se revelando também. Algumas decisões nos conduziram a encaminhamentos pontuais, aparentemente irrelevantes, mas, que, no conjunto, produziram resultados explanativos gerais. É sobre esses vários encaminhamentos e o que deles restou como contribuição que trataremos a partir deste momento.

Do ponto de vista da produção textual, notamos que a situação de pressão quanto à adesão ao padrão culto a que os candidatos a vestibulares e os autores de teses são submetidos move-os em busca de itens que não provoquem minimização da assertividade, que - imaginam - lhes cobrarão seus leitores e avaliadores. Com vistas a identificar uma solução de esquiva, lançam mão de usos diversos. A despeito disso, a construção quase que, além de figurar entre redações classificadas entre as melhores de cada ano, é empregada em resumos de teses, cuja exigência da norma culta e do padrão formal é ainda maior. O que ocorre, entretanto, é que nem sempre há uma forma melhor do que quase que para a intenção que se intui codificar. E é, para isso, que se faz o papel do linguista, que descreve esses usos. 
O movimento intencional de lidar sintaticamente com a informação altamente complexa desenha o percurso de atuação de um princípio funcionalista, como a demarcar mentes em interação a cada construção selecionada. Entra em campo para explicar essa interação o subprincípio da quantidade, que corresponde a uma solução de quantidade de codificação suficiente para corresponder à quantidade ou complexidade da informação. Manifesta-se, dessa forma, uma solução icônica, já que o emprego de quase que, mais complexa construcionalmente, codifica, justamente, a informação que mais elementos sintetiza em si: responde à sintaxe codificada, consolida o foco do escrevente e produz, no interlocutor, a defesa necessária de sua posição argumentativa, trazendo para o texto a iminência e a preservação da face. Essa solução beneficia o autor do texto, que é - se podemos dizer assim - protegido em sua competência ideológica ou de background informacional. Concorrem para o sentido codificado a semântica elaborada e a pragmática idealizada, revestidas em forma de encadeamento sintático típico de escrevente bem preparado e coerente com redações bem pontuadas ou com trabalhos científicos em nível de pós-graduação.

Durante o percurso de investigação, deparamo-nos com a questão sobre o locus de nascimento desse receio da imprecisão ou aproximação semântica. Uma das estratégias adotadas para a busca de resposta foi a incursão a materiais do ensino básico de língua materna. Trabalhamos, então, com a questão das classes de palavras e o tratamento a elas destinado no ensino escolar, o qual as considera algo exterior ao indivíduo. Esse, também impelido por essa concepção, sente-se obrigado a decorar os membros das classes, como se de fato fossem 'classes fechadas'. Discutimos esse rótulo e mostramos que não se pode conceber limites rígidos, mas zonas de intersecção, e que atuam, portanto, membros intermediários entre protótipos e fronteiras categoriais. $\mathrm{O}$ reconhecimento de elementos periféricos, antes marginalizados pela abordagem categórica, foi essencial para uma análise mais apurada da classificação e do próprio entendimento da categoria dos advérbios, a qual não pode, nessa perspectiva, ser definida a partir de um único conjunto de condições necessárias e suficientes. Essa "riqueza" foi percebida na funcionalidade tão diversa assumida pelo item quase.

Pudemos, a partir dessa verificação, distinguir entre significados mais representacionais do mundo - tal como são os dados de quase classificados como menos subjetivos - e significados mais associados à interação entre falante/escrevente e ouvinte/leitor - tal como o caso dos usos mais subjetivos. Verificamos que essa 
versatilidade deve-se ao fato de os advérbios atuarem em um plano de utilização da língua que oscila entre o campo representacional, típico do léxico, e a área da gramática, relacionada à intersubjetividade, a qual se estabelece entre falante/escrevente e ouvinte/leitor e que, normalmente, se associa aos elementos de caráter gramatical.

Reconhecida, através de nossa análise, como elemento periférico da categoria dos advérbios, a construção quase não apresenta, como atestamos, a típica mobilidade adverbial. Ocupa, com grande predominância, a posição anteposta a seu escopo. A amostragem é robusta tendo em vista a restrição de emprego nos materiais adotados para compor o corpus: foram 17 dados identificados na amostra de cartas de leitores e redatores nos séculos XIX e XX, 32 dados analisados nas redações de vestibular da Fuvest e 1104 extraídos dos resumos de teses e dissertações. Apenas um dado presente em uma carta de leitor do século XIX - apresenta a construção quasi em posição posposta a seu escopo, claramente com a intenção adicional de focalização.

Observamos, assim, que a decisão por uma anteposição ou posposição não é caótica, e, sim, determinada por fatores pragmático-cognitivos: intenções são codificadas na língua e, para isso, diferenciam-se em padrões de codificação sintática. A análise do contexto de exceção em que quasi posiciona-se à direita de seu escopo revelou-nos a intenção, por parte do escrevente, de enfatizar determinada informação, de um modo que não seria possível a partir do posicionamento habitual do item (como vimos, à esquerda do escopo). A quebra do hábito, ainda que inconsciente, naturalmente, sempre se ajusta a uma motivação funcional. Assim, se houver uma motivação a mais para codificar, será a ordem o fator de alteração incorporado ao uso da construção.

Ao atuarem como adjetivos, e assumirem a posição pré-nominal, quase e quase que foram de encontro à análise apresentada por Lima-Hernandes et alii (2013) a respeito dos adjetivos avaliativos, os quais, segundo os autores, apresentariam, muito provavelmente, uma informação não consensual ao posicionarem-se dessa forma. Daí o caráter mais pragmático desses adjetivos, associado à função retórico-argumentativa. De fato, em muitos dos casos analisados, a funcionalidade de quase e quase que estava atrelada à preservação da face do escrevente frente a uma informação por ele considerada não consensual ou que poderia, potencialmente, ser alvo de contestação.

A reconstrução do contexto de interação e das intenções comunicativas dos interlocutores remete ao funcionamento da língua em um viés construcional. O quadro 
descritivo aqui desenvolvido favorece a observação dos tons diversos que as intenções, as atitudes e a negociação de conhecimentos compartilhados demonstram na situação interativa. Se decidirmos lidar, no entanto, com dados linguísticos em termos categóricos, o resultado não será um sistema dinâmico em ação e não alcançaremos a gradação necessária a que falantes/escreventes mobilizam as construções linguísticas para codificar sintaticamente sua experiência.

Mas nem tudo é mudança no sistema linguístico. Há um componente importante de estabilidade que precisa ser compreendido também. Nesta dissertação, rotulamos esse componente de traço semântico resiliente. Intuíamos que as construções sob estudo manteriam uma identidade histórica que nos permitiram vinculá-las e que essa vinculação não seria somente propiciada pela forma parcialmente coincidente. Realizamos, então, o rastreamento histórico de quase e quase que, recorrendo à composição de uma amostra de obras lexicográficas. Foi assim que identificamos seu traço irrealis, o qual se mostrou essencial para a compreensão das funções assumidas pelas construções em questão e também para entender seu percurso na língua.

A análise das cartas de leitores e redatores nos fez perceber que, já no século XIX, quasi codificava intenções muito próximas às que visitamos atualmente nos dados. Quando não era empregado de modo mais concreto, o item sinalizava subjetividade. Tratava-se de avaliações próprias dos escreventes, como em uma desgraça quasi certa; quasi succumbimos; quasi um balaio, quasi que em um arrebaldo. Desse modo, o item passou a pertencer ao domínio discursivo-pragmático, codificando uma informação pertinente ao interactante e não à informação em si, revestindo as construções de uma valoração imposta pela subjetividade do escrevente. A partir da análise de seu contexto de emprego nas redações dissertativas de vestibular, por sua vez, concluímos que o uso de quase se configurava como estratégia modalizadora da argumentação nessa situação comunicativa.

Um dado bastante interessante por nós identificado foi a classificação de quase que como gíria por um autor, o que denunciaria um uso corriqueiro no cotidiano em situações de oralidade ${ }^{162}$. Esse fato tornou-se ainda mais curioso quando, em

\footnotetext{
${ }^{162}$ No prefácio da $1^{\text {a }}$ edição, o autor afirma: "Nós, os brasileiros, insistimos em conservar parada a mesma língua que no berço prossegue seu curso natural do ser vivo. [...] Êste dicionário não trata apenas dos verbetes da gíria nacional, pois, à medida que os colecionávamos, controlando-os com os mais recentes dicionários da nossa língua, encontrávamos repetidas lacunas de palavras, modismos, expressões que, não sendo propriamente da gíria popular, mereciam citados neste glossário, uma vez que não estavam ainda mencionados nos supra dicionários.”. No prefácio da $3^{\mathrm{a}}$ edição, há a ressalva:
} 
rastreamento histórico, identificamos o emprego ${ }^{163}$ de quase que, já em 1887, em uma carta de leitor, em uma situação comunicativa escrita dotada de menor grau de formalidade, mais próxima ao âmbito da fala. Em textos mais formais do mesmo período, entretanto, foram identificados apenas usos de quase, nenhum de quase que. Em corpus sincrônico, detectamos o emprego da construção em situações comunicativas escritas que exigem um maior grau de formalidade: redações vestibulares e resumos de teses e dissertações. Esse percurso, hipotetizamos, poderia ser sinalizador de um processo de gramaticalização em curso. Ao rastrearmos ocorrências em obras literárias, entretanto, surpreendemo-nos com quase que presente em obras do século XIX, num uso modelar e formal que nos revelou que o processo de mudança já estava instaurado há mais de dois séculos.

De fato, o emprego de quase, já no latim, com funções diversas, teria iniciado seu processo de gramaticalização. Além da função prepositiva, altamente gramaticalizada, verificamos que também já funcionava como advérbio, e isso estava referendado por Bluteau. E, das referendações lexicográficas, depreendemos a abstratização do conteúdo semântico:

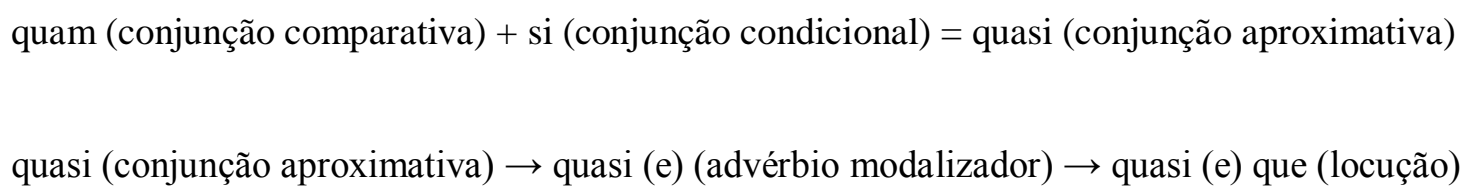

Voltamos ao lugar seguro de nossa especialidade, pois confirmamos mais uma vez que construções mais concretas tornam-se mais abstratas, especializando-se como mais gramaticais, de modo a colaborar com a transmissão de intenções. Se, no início do trabalho, relatamos que havíamos verificado que esse percurso era desenhado pelos usos de meio e meio que, agora, ao final desta dissertação, essa ideia se reforça, pois também com quase e quase que essa rota de mudança se configurou. Sendo assim, não é a rota em si que se notabiliza, mas o processo de gramaticalização que se reforça como um processo unidirecional, como um universal linguístico.

\footnotetext{
"Já se encontram dicionarizadas algumas centenas de palavras compiladas pelo autor em época anterior ao aparecimento de novos e magníficos dicionários da língua.".

163 "quasi que em um arrebaldo".
} 
Não podemos perder de vista, a despeito disso, que, do ponto de vista pragmático, gramaticalizar construções é a maneira que seres humanos encontram para transmitir intenções, seja porque não há outra forma de atingir esse objetivo, seja porque essa forma perdeu sua eficiência. Mais do que isso: as intenções que reverberam ou que são hesitosas ganham formas semelhantes, no caso as construções X-que, em que o item que traz um componente irrealis decisivo. Daí concluirmos que gramaticalizar equivale à sintatização de intentos pragmáticos. Ecoa, nessa conclusão, a ideia givoniana de que a pragmática do passado é a sintaxe do presente.

De um ponto de vista gramatical, a breve análise que realizamos do itinerário histórico das conjunções desde o latim clássico, passando pelo vulgar e chegando ao português, mostrou-nos a coexistência de duas tendências contrastantes na língua: uma relacionada à drástica redução da quantidade de conjunções ao longo do tempo; e a outra, à ampliação dessa quantidade, causada pela adaptação de palavras de outras classes à função de conjunção e pela formação de locuções conjuntivas, baseadas em que.

A partir da amostra de controle - resumos de teses defendidas na Universidade de São Paulo - identificamos três padrões de subjetividade de quase. Inicialmente, aplicamos o princípio de iconicidade e percebemos a atuação de dois subprincípios: o da quantidade - a intenção de transmitir mais informação e informação mais complexa é codificada sintaticamente com forma maior e também mais complexa - e o da distância - o distanciamento cognitivo entre conceitos é codificado através de distanciamento sintático entre os mesmos. Ambos são verificados no emprego de quase que: a junção à conjunção que significa mais forma e maior distância em relação ao escopo.

Essa reflexão nos conduziu à conclusão de que há uma escala de envolvimento do sujeito escrevente em três padrões organizadores do conjunto de dados. A ideia é que a intenção de se aproximar argumentativamente do leitor-interlocutor seja codificada sintaticamente por meio de uma gradação de subjetividade: menos subjetivo (porque não concebemos uma objetividade isenta do sujeito), subjetivo propriamente dito e intersubjetivo. Mas há uma carga de consciência linguística também que nos permite afirmar que nem todo ser humano estaria apto a empregar, em sua fala, a construção quase que com as funções observadas nas teses, por exemplo.

Nos exemplos menos subjetivos, observamos o emprego de quase na expressão de valores imprecisos. Nesses usos, o falante favorece a depreensão de sua intenção de 
situar o referente num espaço circunstancial de observação mais precisamente. Foram três os subpadrões identificados: (i) imprecisão espacial; (ii) imprecisão quantitativa em muitos casos, com a intenção de conduzir à impressão de amplitude, sem que houvesse, porém, comprometimento por parte do autor, dessa forma, a exposição de um dado de forma imprecisa, possibilitada pelo emprego de quase, conduz o leitor a assumir como informação uma quantidade maior do que aquela a qual seria indicada pela quantificação exata, precisa; (iii) imprecisão temporal.

Os usos subjetivos propriamente ditos, por sua vez, são aqueles em que se observa a ação do autor-escrevente ao manipular as informações. Foram divididos em dois subpadrões: ênfase na percepção de proximidade do escrevente e ênfase na prototipia desconstruída pelo escrevente.

Os primeiros referem-se aos casos em que quase atua atribuindo traço de polaridade negativa sob escopos de polaridade altamente positiva, com traço de indefinição ou imprecisão, tais como todo(s), toda(s), tudo, totalidade, total, sempre. Os segundos são casos em que quase toma como escopo o valor categórico em si, com vistas a produzir efeito focalizador da prototipia a que se visa defender. Foram subdivididos também de acordo com o escopo: (i) escopo adverbial de polaridade altamente positiva; (ii) escopo adjetival de polaridade altamente positiva; (iii) escopo conjuncional de base comparativa como e (iv) escopo verbal que produz um efeito irreversível em sua polaridade altamente positiva.

Em todos os dados subjetivos, observamos, entre outros, dois processos envolvidos: preservação de face do escrevente, pois quase impede a interpretação de que o escrevente empenha sua palavra e imagem totalmente ao que escreve (pode haver algo a mais, pode haver algo a menos) e, por outro lado, os conceitos pretendidos pelos escopos são transmitidos, os frames a eles relacionados são acessados pelo leitor. A impressão causada pelo conceito presente no escopo fica marcada, ao mesmo tempo em que a face do escrevente é protegida. Em outras palavras, os mecanismos linguísticos de significação dos escopos são acionados pelos interlocutores, entretanto, quase "controla" o modo como deverão ser recepcionados.

Nos dados intersubjetivos, nota-se a inferência, por parte do falante/escritor, da percepção ou compreensão que o ouvinte/leitor fará de sua mensagem, a partir de "pistas" socialmente estabelecidas e que codificam sintaticamente a ação do autorescrevente ao manipular as informações. Quase codifica, nesses casos, um grau 
intermediário de polaridade negativa total, sinalizada pelos escopos adverbiais, preposicionais e pronominais de caráter indefinido, como os advérbios não e nunca; o pronome indefinido nada; os pronomes adjetivos nenhum(a) e a preposição sem. O escopo da negação é a própria partícula negativa, que deve ser interpretada como um grau menor de negação nos casos em que esse padrão é empregado.

Um olhar mais atento sobre os dados e seus padrões nos fez reconhecer quatro diferentes mecanismos atuantes no emprego de quase:

(i) aproximação ao polo de uma escala: no caso dos números uma escala de quantificação e, nos outros casos, de graus (qualificação);

(ii) seleção da maioria dos membros de um conjunto (quantificação);

(iii) seleção da maior parte de uma "massa" (partitude); e

(iv) aproximação a uma esfera (englobamento de um conceito).

Depois de ter se fixado como item codificador de aproximação bastante rente talvez, a mais rente possível - a quantificações, hipotetizamos que o conceito de posicionamento de um valor em uma escala tenha se semanticizado como parte do significado de quase, que passou a codificar também valores avaliativos, transformando-se em um modificador de graus. Esses valores poderiam ser distribuídos nas seguintes escalas de abstratização sugeridas, obedecendo a pressupostos teóricos da cognição (em seus princípios da evolução ontogênica) e da gramaticalização (em seus princípios de complexidade gramatical), os quais admitem que quantidade é categoria mais básica do que qualidade e que parte é mais básica que a compreensão do todo:

a) Hipótese unilinear de gramaticalização

quantificação (escala e seleção de membros) > partitude > qualificação > esfera

b) Hipótese poligramaticalização

quantidade $>$ parte $>$ soma $>$ totalidade

qualidade > abrangência

Ao funcionar como advérbio e como adjetivo, a construção quase, a depender do escopo, codifica qualidade, uma categoria cognitiva abstrata, a qual tem relação 
direta com uma ação muito complexa e abstrata de qualificar informações e a qual demanda muito pouco de conhecimento externo, pois uma configuração construcional abstrata guia todo o aparato cognitivo a funcionar com o que de mais básico possui em seu computador orgânico, ou seja, a mente: o processo analógico. O fato é que todo indivíduo, desde cedo, estabelece comparações, o que lhe permite reconhecer não somente um processo útil para comunicar ideias e avaliações, mas, acima de tudo, lhe garante a mobilização de um mecanismo ativo para aprender qualquer coisa, inclusive se comunicar. Transportar o conceito de aproximação entre âmbitos e, ainda, fazê-lo codificar incerteza só são processos possíveis graças a um aparato cognitivo, que é analógico por natureza, e percebe a forte contiguidade entre as concepções de aproximação e incerteza.

No processo de gramaticalização de quase, traços do conceito-fonte, dedicados à descrição do mundo sociofísico (espaço e tempo), foram mobilizados para desempenhar novas funções. O efeito é a representação de eventos no mundo das relações interpessoais. A construção quase ativa uma moldura conceitual sob a qual o elemento referenciador ou uma dada informação é/deve ser perspectivado (a) e compreendido (a). Essa questão, portanto, situa-se, primordialmente, no domínio da cognição e pragmática, mas, ao final do processo mental, é revestida de sintaxe e se ganha o mundo como discurso.

Desenvolver este trabalho acadêmico nos conduziu a refletir sobre a realidade do ensino de língua portuguesa. Os livros didáticos foram mobilizados como representantes do discurso escolar e, por esse motivo, tivemos o cuidado de selecionar aqueles manuais aprovados pelo PNLD (Programa Nacional do Livro Didático) e usados em larga escala por escolas brasileiras. A abordagem funcionalista, que em grande medida carrega o que se defende no Plano Curricular Nacional de Língua Portuguesa, nos permite emitir uma avaliação de juízo neste ponto da dissertação: é premente a mudança de rumo no ensino proposto pelos livros e gramáticas. Para alinhar-se ideologicamente ao PCN, a abordagem de conteúdos gramaticais a partir de suas funções desempenhadas em uso real deve ser apresentada. As classes gramaticais não podem continuar a ter suas propriedades puramente descritas como parte de um sistema autônomo, apartado do uso, apartado do movimento dinâmico das interações sociais. É preciso que os alunos tenham acesso ao seu direito pleno de refletir sobre língua, ao seu direito de desenvolver a percepção de que a língua não é uma estrutura estática, mas, sim, uma ferramenta de 
uso para fim de interação entre os seres humanos e para a comunicação de intenções. A desassociação entre o ensino da gramática e o trabalho com a produção de texto, verificada nos mesmos livros e gramáticas analisados, coloca-se como problema-chave. Ao vivenciar conscientemente a gramática de forma descontextualizada, desvinculada de uma situação comunicativa, é natural que se provoque antipatia, que se distancie de quem precisa compreendê-la para ter sucesso em suas investidas comunicativas. Entender a gramática sob a perspectiva funcionalista significa compreender os caminhos de desenvolvimento (mudança, gramaticalização e construcionalização), o que nos permite vivenciar o funcionamento da mente humana por meio de seu produto mais eficiente para alcançar propósitos: a língua. Refletir a respeito das mudanças a que esta é suscetível torna-se fundamental, pois, como afirmou Laraia (2003):

\begin{abstract}
(...) cada sistema cultural está sempre em mudança. Entender esta dinâmica é importante para atenuar o choque entre gerações e evitar comportamentos preconceituosos. Da mesma forma que é fundamental para a humanidade a compreensão das diferenças entre povos de culturas diferentes, é necessário saber entender as diferenças que ocorrem dentro do mesmo sistema. Este é o único procedimento que prepara o homem para enfrentar serenamente este constante e admirável mundo novo do porvir. (LARAIA, 2003:101)
\end{abstract}

Ao invés de condenar os usos que seriam considerados incorretos pela gramática tradicional, a escola deve propiciar sua compreensão. Pensar de forma a compreender-se como usuário e como mola propulsora das mudanças linguísticas é o desafio que se coloca. A mente é um sistema complexo e inalcançável, se desconsiderarmos os sinais que emite e que estão, inegavelmente, presentes em qualquer extrato de interação social.

Frei, um dos principais representantes da Escola de Genebra, vinculada ao funcionalismo, notabilizou-se por sua análise referente aos desvios da gramática normativa, que, segundo sua proposta, não são fortuitos, arbitrários, mas, sim, refletem tendências resultantes de necessidades comunicativas e constituem, portanto, uma rica fonte de estudos linguísticos. Esse seria o caso da construção quase que, condenada pela gramática normativa, mas produtiva na língua em uso e atuante para atender a necessidades comunicativas diferentes - codificação de informações mais complexas e mais distantes cognitivamente - daquelas atendidas por quase.

E, se restava algum preconceito sobre usos clássicos da língua e os usos de quase que, este caiu por terra. Evidenciamos que essa construção é estratégia comunicativa em obras literárias no Brasil e em Portugal em vários momentos da 
história. Sendo assim, nem tudo o que é condenado tem, enfim, um fundo de realidade histórica, mesmo dentro da tradição clássica. O preconceito é fundado em mitos, não em usos.

Cognição, consciência, experiência, cérebro, interação, sociedade, cultura estão intrinsecamente conectados de formas complexas e dinâmicas na linguagem. Apesar disso, ao invés de caos nessas conexões, o que temos são padrões: padrões diacrônicos de mudança linguística, regidos por processos organizatórios universais de movimentos linguísticos, tais como a gramaticalização.

Todo o fazer-se da língua é um processamento cognitivo-social. E, como amplamente defendemos aqui, o processo de gramaticalização é um processo cognitivo, cujo reflexo é a dinâmica dos usos (social). As várias funcionalidades assumidas por uma construção sinalizam retratos de sua evolução. Em suma, se a língua reage a forças icônicas para modelar seu produto formal, não é o acaso que responde por isso e tampouco o caos a revolve. Processamentos cognitivos humanos (por exemplo, atenção e memória) guiam-na num movimento contínuo influenciado por forças que operam simultaneamente a depender de motivações, capacidades e interesses. 


\section{Referências bibliográficas}

AIKHENVALD, Alexandra Y. Evidentiality. New York: Oxford University Press Inc., 2004.

ALBANI, F. V. L. Ordenação do advérbio sempre no português arcaico e no contemporâneo. Dissertação de Mestrado em Linguiística na UFRJ. Rio de Janeiro, 2007.

ALMEIDA, Napoleão Mendes de. Gramática latina. São Paulo: Editora Saraiva, 1985.

ALMEIDA, M. A.; FIGUEIREDO J. N. Compêndio de gramática latina. Porto: Porto Editora, s.d.

ANTTILA, Raimo. Analogy: The warp and woof of cognition. In: Joseph, Brian D., and Richard D. Janda (Eds.), The handbook of historical linguistics. Oxley: Blackwell, 2003, pp. 425-440.

BARBOSA, J. Soares. Grammatica Philosophica da Lingua Portugueza ou Principios da Grammatica Geral applicados á nossa linguagem. Lisboa: Typographia da Academia Real das Sciencias, (1866) [1822].

BARROS, Rafael Fernandes; SANTOS, Rafael Peres dos; FURLAN, Fábio Augusto; CAMILO, Lujani Aparecida; PEREIRA JR., Alfredo. Efeitos de relevância versus repetição de estímulo linguístico na indicação da memória declarativa. In: Neurociências. Vol. 7, 2011.

BATISTA, Adriana Santos. Rotas de Gramaticalização no português: estruturas tirarque no português culto de São Paulo. Relatório Final de Pesquisa de Iniciação Científica entregue à Fapesp (processo 07/01331-0). São Paulo, 2008.

BECHARA, Evanildo. Moderna Gramática Portuguesa. Rio de Janeiro: Editora Lucerna, 1999; 2004.

BECKNER, Clay; BLYTHE, Richard; BYBEE, Joan; CHRISTIANSEN, Morten H.; CROFT, William; ELLIS, Nick C.; HOLLAND, John; KE, Jinyun; LARSENFREEMAN, Diane; SCHOENEMANN, Tom. Language is a complex adaptive system: position paper. In: Language Learning 59: Suppl. 1. University of Michigan: 2009, p. 126.

BENVENISTE, Émile. Problèmes de linguistique générale. Paris: Gallimard, v. 1, 1966.

BENVENISTE, Émile. Problèmes de linguistique générale. Paris: Gallimard, v. 2, 1974.

BLEST, A. The concept of 'ritualization'. In: THORPE, W.; ZANGWILL, O. (eds). Current Problems in Animal behavior. Ed. Cambridge: Cambridge University Press, 1963, p. 102-125.

BLUTEAU, R. Vocabulário portuguez \& latino. Coimbra: Collegio das Artes da Companhia de Jesu, 1712 -1728, p.25. 
BRASIL. MINISTÉRIO DA EDUCAÇÃO. Secretaria de Educação Fundamental: Parâmetros Curriculares Nacionais: $5^{a}$ a $8^{a}$ série. Brasília: MEC/SEF,

BYBEE, Joan; HOPPER, Paul. Frequency and the emergence of linguistic structure. John Benjamins Publishing Company: Amsterdam, 2001.

BYBEE, Joan. Cognitive processes in grammaticalization. In: Michael Tomasello (ed.), The New Psychology of Language, volume 2. Mahwah, New Jersey: Lawrence Erlbaum, 2003a. (pp. 145-167).

$2003 b$.

Phonology and Language Use. Cambridge: Cambridge University Press, Press, 2007.

Frequency of use and the organization of language. USA: Oxford University 2010 .

Language, Usage and Cognition. Cambridge: Cambridge University Press,

CACCIAGUERRA, Vanessa; OLIVEIRA, Anna Karolina Miranda. Gramaticalização do item mesmo: a mudança nas línguas românicas. Revista Anagrama: Revista Científica Interdisciplinar da Graduação, Ano 3. Ed. 1. set/nov. 2009. Disponível em: <http://www.revistas.univerciencia.org >. Acesso em: 10/10/2013.

CALDAS AULETE, Francisco Julio. Diccionario contemporaneo da língua Portuguesa. Lisboa: Parceria Antônio Maria Pereira, 1881.

CÂMARA JR, Joaquim Mattoso. Dicionário de Filologia e Gramática referente à Língua Portuguesa. 2.ed. São Paulo: J. Ozon, 1964.

1976.

História e estrutura da língua portuguesa. 2. ed. Rio de Janeiro: Padrão,

CASSEB-GALVÃO, Vânia Cristina. De predicação matriz a operador evidencial. A gramaticalização de diz que. In: VEREDAS - Revista de Estudos Linguísticos, Juiz de Fora: 2004. v.8, n.1 e n.2, p.163-181.

CASTILHO, Ataliba Teixeira de. Nova Gramática do Português Brasileiro. 1. ed. $1^{\mathrm{a}}$ Reimpressão. São Paulo: Contexto, 2010.

\& ELIAS, Vanda Maria. Pequena Gramática do Português Brasileiro. São Paulo: Editora Contexto, 2012.

CEREJA, William Roberto; MAGALHÃES, Thereza Cochar. Português: Linguagens, vol. $6,6^{\circ}$ ano do ensino fundamental. Ensino fundamental II. São Paulo: Atual, 2009. (Conforme nova ortografia)

Português: Linguagens, vol. 7, $7^{\circ}$ ano do ensino fundamental. Ensino fundamental II. São Paulo: Atual, 2009. (Conforme nova ortografia)

Português: Linguagens, vol. 8, $8^{\circ}$ ano do ensino fundamental. Ensino fundamental II. São Paulo: Atual, 2009. (Conforme nova ortografia) 
Português: Linguagens, vol. 9, $9^{\circ}$ ano do ensino fundamental. Ensino fundamental II. São Paulo: Atual, 2009. (Conforme nova ortografia)

. Gramática: texto, reflexão e uso. $3^{\mathrm{a} e d .}$ Reform. São Paulo: Atual, 2008.

CINQUE, G. \& RIZZI, L. The Cartography of sintactic structures. CISCL Working Papers 2, 2008.

CORACINI, M. J. Um fazer persuasivo: o discurso subjetivo da ciência. Campinas: Pontes, 1991.

CROFT, William. Radical Construction grammar: syntactic theory in typological perspective. Oxford: Oxford University Press, 2001, p. 448.

Toward a social cognitive linguistics. In: EVANS, Vyvyan; POURCEL, Stéphanie (Eds). New Directions in Cognitive Linguistics, 2009.

CUNHA, Celso Ferreira da \& CINTRA, Luís Filipe Lindley. Nova Gramática do Português Contemporâneo. Rio de Janeiro: Nova Fronteira, 1985.

. Nova Gramática do Português Contemporâneo. $3^{\mathrm{a}}$ ed. Rio de Janeiro: Nova Fronteira, 2001.

DALGALARRONDO, Paulo. Evolução do cérebro: sistema nervoso, psicologia e psicopatologia sob a perspectiva evolucionista. Porto Alegre: Artmed, 2011.

DEL NERO, H. S. O sítio da mente: pensamento, emoção e vontade no cérebro humano. São Paulo: Collegium Cognitio, 1997.

DIEWALD, Gabriele. Context types in grammaticalization as constructions. In: Constructions. Special Volume 1: Constructions all over - case studies and theoretical implications. hg. Doris Schönefeld, 2006.

EIBL-EIBESFELDT, Irenäus. A unidade biológica da humanidade: etologia humana, conceitos e implicações. In: Perspectivas. Revista Trimestral de Educação da Unesco. Vol. II. Lisboa: Livros Horizonte, 1976, p. 163 - 181.

FAUCONNIER, G. Mappings In Thought And Language. Cambridge: Cambridge University Press, 1997.

FERRARI, L. Introdução à Linguística Cognitiva. São Paulo: Contexto, 2011.

FERREIRA, Aurélio Buarque de Holanda. Novo Aurélio Século XXI: O dicionário da língua portuguesa. 2. ed. Rio de Janeiro: Nova Fronteira, 1986 (p. 1427).

Novo Aurélio Século XXI: O dicionário da língua portuguesa. 3. ed. Rio de Janeiro: Nova Fronteira, 1999, p. 1167; 1309 - 1310.

FERREIRA, António Gomes. Dicionário de Latim-Português. Porto: Porto Editora, 1988.

FERREIRA, Lucia Maria Alves. Estabilidade e continuidade semântica e sintática. In: FURTADO DA CUNHA, Maria Angélica; OLIVEIRA, Mariangela Rios de; 
MARTELOTTA, Mário Eduardo Lingüística funcional: teoria e prática. Rio de Janeiro: Faperj/DP\&A, 2003, p. 73 - 87.

FODOR, J. A. Banish discontent. In BUTTER FIELD, J. (ed.) Language, mind and logic. Cambridge: Cambridge University Press, 1985.

FREI, Henri. La Grammaire des Fautes, (Reimpressão da edição de 1929). GenèveParis, Slaktine Reprints, 1982.

FRISCH, K.V. The dance language and orientation of bees. Londres: Oxford University Press, 1967.

FURTADO DA CUNHA, Maria Angélica; COSTA, Marcos Antônio \& CEZARIO, Maria Mauro. Pressupostos teóricos fundamentais. In: FURTADO DA CUNHA, Maria Angélica; OLIVEIRA, Mariangela Rios de \& MARTELOTTA, Mário Eduardo Lingüística funcional: teoria e prática. Rio de Janeiro: Faperj/DP\&A, 2003.

\& SOUZA, M. M de. Transitividade e seus contextos de uso. Rio de Janeiro: Lucerna, 2007.

. BISPO, Edvaldo Balduino; SILVA, José Romerito. Linguística Funcional Centrada no Uso: princípios básicos e categorias analíticas. In: Linguístia centrada no uso: uma homenagem a Mário Martelotta, 2013.

GALLESE, Vittorio. Intentional Attunement. The Mirror Neuron system and its role in interpersonal relations. In: European Science Foundation, Institut Nicod, 2004.

GEERAERTS, D. A rough guide to Cognitive Linguistics. (1989) In: Cognitive linguistics: basic reading. Berlim: Walter de Gruyter GmbH \& Co, 2006, (p. 1 - 28).

GERREVINK, Richard van; HOOP, Helen de. On the rhetorical use of almost. In: ALONI, Paul Dekker Mari \& ROELOFSEN, Floris (eds.). Proceedings of the Sixteenth Amsterdam Colloquium. Amsterdam: ILLC, University of Amsterdam, 2007, p. 229234.

GIVÓN, Talmy. On understanding grammar. New York: Academic Press, 1979.

- Topic Continuity in Discourse: A Quantitative Cross Language Study. Typological Studies in Language 3. Amsterdam: John Benjamins, 1983.

. Syntax. A functional-typological introduction. Volume II. Amsterdam: John Benjamins, 1990.

Functionalism and Grammar. Amsterdam/Philadelphia: John Benjamins Publishing Company, 1995. 2001.

Syntax: an introduction. Vol. I. Amsterdam/Philadelphia: John Benjamins,

Context as other minds; the pragmatics of sociality, cognition and communication. Amsterdam/Philadelphia: John Benjamins, 2005.

GOFFMAN, Erving. A representação do eu na vida cotidiana. Trad. Maria Célia Santos Raposo. Petrópolis: Vozes, 1985. 
GOLDBERG, A. E. Constructions: a new theoretical approach to language. Trends on Cognitive Sciences, v 7, n 5, 219-224, 2003.

GOMBERT, J.E. Atividades Metalingüísticas e Aprendizagem da leitura. In: Maluf, M.R. (Org.) Metalinguagem e aquisição da escrita: contribuições da pesquisa para a prática da alfabetização. São Paulo: Casa do Psicólogo, 2003.

GONÇALVES, Sebastião Carlos Leite. Grammaticalização, modalidade epistêmica e evidencialidade: um estudo de caso no português do Brasil. Campinas: UNICAMP, 2003. (Tese de Doutorado).

GUERRA, Alexandre Yuri R. Expressões de assombro e de estranheza no português paulistano: a hipótese do peso. Projeto de iniciação científica. São Paulo: USP/Ensinar com Pesquisa, 2011.

GUERRA, Alexandre Yuri R. A língua oral e o desenvolvimento de sua articulação por crianças em processo de letramento. In: Anthesis: Revista de Letras e Educação da $\begin{array}{llll}\text { Amazônia } & \text { Sul-Ocidental. Ano } & 2013 .\end{array}$

GUERRA, Alexandre Yuri R. A percepção de intencionalidade e causalidade no uso linguístico por crianças e adolescentes portadores de TEA de alto funcionamento. Projeto de mestrado. São Paulo: USP/Faculdade de Filosofia, Letras e Ciências Humanas, 2014.

HAIDO, T. M. C. A reorganização discursiva em entrevistas jornalísticas. Dissertação (Mestrado em Linguística) - Universidade Federal do Rio de Janeiro, Rio de Janeiro. 1996.

HAIMAN, John. Ritualization and the Development of Language. In: PAGLUICA, William. Perspectives on Grammaticalization. Amsterdam: John Benjamins Publishing Company, 1994.

HALLIDAY, Michael A.K. Introduction to Functional Grammar, London: Edward Arnold, 1985.

HEINE, Bernd;CLAUDI, Ulrike \& HÜNNEMEYER, Friedderike. Grammaticalization: a conceptual framework. Chicago e London: The University of Chicago Press, 1991.

Grammaticalization. In: JOSEPH, Brian \& JANDA, Richard D. (eds.) The Handbook of Historical Linguistics. Oxford: Blackwell, 2003 (p. 575-601) Press, 2007.

\& KUTEVA, Tania. The Genesis of Grammar. New York: Oxford University

HENGEVELD, Kees. Layers and operators in Functional Grammar. In: J. Linguistics, n. 25 , p. $127-57,1989$.

HOPPER, Paul J. On some principles of grammaticalization. In: TRAUGOTT, Elizabeth Closs \& HEINE, Bernd (eds.) Approaches to grammaticalization. Vol. I: Focus on theoretical and methodological issues. Amsterdam/Philadelphia: John Benjamins Publishing, 1991(p. 17-36). 
\& TRAUGOTT, Elizabeth Closs. Grammaticalization. Cambridge: Cambridge University Press, 2003 [1993].

\& THOMPSON, Sandra A. Transitivity in Grammar and Discourse. In: Language, v. 56, n. 2, 1980.

HOUAISS, A.; VILLAR, M. S. Dicionário Houaiss da língua portuguesa. 1.ed. Rio de Janeiro: Objetiva, 2009, p. 1586.

1883).

Dicionário Houaiss da Língua Portuesa. Rio de Janeiro: Objetiva, 2001. (pp.

JACKENDOFF, R. Semantics and Cognition. Cambridge, MA: MIT Press, 1983.

JUCÁ FILHO, Cândido. O fator psicológico na evolução sintática. Rio de Janeiro: Fundação Getúlio Vargas, 1971.

KATZ, J. J.; FODOR, J. A. The structure of a semantic theory. Language, 1963, p. 39.

LABOV, W. The boundaries of words and their meaning. In: BAILEY, C.; SHUY, R. (eds.). New ways of analyzing variation in English. Washington DC: Georgetown University Press, 1973, p. 340-373.

LAKOFF, G. Women, fire and dangerous things: what categories reveal about the mind. Chicago: University of Chicago Press, 1987.

LANGACKER, Ronald. Observations and speculations on subjectivity. In: John Haiman, ed., Iconicity in Syntax, Amsterdam and Philadelphia: John Benjamins, 1985, pp. 109-150.

Foundations of Cognitive Grammar, Volume 1, Theoretical Prerequisites. Stanford: Stanford University Press, 1987.

- The Rule Controversy: A Cognitive Grammar Approach. San Diego: University of California, 1990.

Press, 2008.

Cognitive Grammar: A Basic Introduction. New York: Oxford University

LARAIA, Roque de Barros. Cultura: Um conceito antropológico. $16^{\mathrm{a}}$ ed. Rio de Janeiro: Jorge Zahar, 2003.

LIGHTFOOT, David. The child's trigger experience: Degree-0 learnability (target article) In: Behavioral \& Brain Sciences 12.2, 1989, p. 321-334.

LIMA, H.; BARROSO, G. Pequeno Dicionário Brasileiro da Língua Portuguesa. 6.ed. Rio de Janeiro: Editora Civilização Brasileira, 1946, p. 1029.

LIMA-HERNANDES, Maria Célia. Estratificação de usos linguísticos: inovação e mudança. In: Estudos Linguísticos. São Paulo: GEL, v. 10, 2005 (p. 307-318). 
Rotas de Gramaticalização no Português do Brasil: Estruturas X-que no Português culto e o impacto das contribuições paulistas de 1995 a 2005. São Paulo, 2006.

\& DEFENDI, Cristina Lopomo. Estruturas X-que e atuação metonímica: gramaticalização de tanto que no Português. ALFINGE, v. 18, p. 109-126, 2006.

\& CASSEB-GALVÃO, Vânia Cristina. Gramaticalização e ensino. In: GONÇALVES, Sebastião Carlos Leite; LIMA-HERNANDES, Maria Célia; CASSEBGALVÃO, Vânia Cristina. (org). Introdução à gramaticalização. São Paulo: Parábola Editorial, 2007.

\& CASSEB-GALVÃO, Vânia Cristina. As rotas de gramaticalização de DIZ QUE e TIPO no português do Brasil. In: Ronald Beline Mendes. (Org.). Passando a Palavra: uma homenagem a Maria Luiza Braga. 1 ed. São Paulo: Paulistana Editora, 2007, v. 1, p. 105-122.

Esquecimento histórico e mudança lingüística: um risco de vida no português brasileiro. In: LIMA-HERNANDES, M.C.; MARÇALO, M.J.; MICHELETTI, G.; ROSSI, V.L.. (Org.). A Língua Portuguesa no Mundo - I Simpósio Mundial de Estudos de Língua Portuguesa. São Paulo: FFLCH-USP, 2008, v. 1.

\& CASSEB-GALVAO, Vânia Cristina. O equilíbrio damudança linguística: a gradualidade em processo. In: Edson Rosa de Souza. (Org.). Funcionalismo linguístico - novas tendências teóricas. 1ed. São Paulo: Contexto, 2012, v. 1, p. 153-170.

; SILVA, José Romerito; OLIVEIRA, Mariângela Rios de; DIAS, Nilza Barrozo; CASSEB-GALVÃO, Vânia Cristina. O adjetivo. In: CASTILHO, Ataliba Teixeira de. (org.) História do Português Paulista. Capítulo inédito, 2013.

LÖFSTEDT, Einar. Philologischer Kommentar zur Peregrinatio Aetheriae. Upsala, 1911.

LYONS, John. Deixis and subjectivity: Loquor, ergo sum? In: R. J. Jarvella and W. Klein (eds.), Speech, place, and action: studies in deixis and related topics. Chichester and New York: John Willey, 1982. p. 101-24.

MACHADO, José Pedro. Dicionário Etimológico da Língua Portuguesa. 2.ed. São Paulo: Livros Horizonte, 1967 (p. 1923).

MARCUS, G. F.; VIJAYAN, S.; BANDI RAO, S.; VISHTON, P.M. Rule learning by seven-month-old-infants. In: Science, 283. New York: AAAs, 1999, p. 77-80.

MARCUSCHI, Luiz Antônio. A construção do mobiliário do mundo e da mente: linguagem, cultura e categorização. In: MIRANDA, Neusa Salim e NAME, Maria Cristina (orgs.). Lingüística e cognição. Juiz de Fora: Editora UFJF, 2005. p. 49-77.

MARGERIE, Hélène. From downgrading to (over) intensifying: a pragmatic study in English and French. In: KECSKÉS, István \& HORN, Laurence H. Explorations in pragmatics: linguistic, cognitive and intercultural aspects. Berlin: Mouton de Gruyter, 2007 (pp. 287-312). 
MARTELOTTA, Mário Eduardo; VOTRE, Sebastião Josué; CEZARIO, Maria Maura. O paradigma da gramaticalização. In: MARTELOTTA, Mário Eduardo; VOTRE, Sebastião Josué; CEZARIO, Maria Maura. (org). Gramaticalização no português do Brasil - uma abordagem funcional. Rio de Janeiro: Tempo Brasileiro, 1996. p. 45-75.

(Mimeo), 1998.

Figura e fundo: uma proposta prática de análise. Rio de Janeiro: UFRJ

A mudança lingüística. In: FURTADO DA CUNHA, Maria Angélica; OLIVEIRA, Mariangela Rios de \& MARTELOTTA, Mário Eduardo. (ORG.) Lingüística funcional teoria e prática. Rio de Janeiro, DP\&A, 2003.

\& AREAS, E. K. A visão funcionalista da linguagem no século XX. In: FURTADO DA CUNHA, Maria Angélica; OLIVEIRA, Mariangela Rios de; MARTELOTTA, Mário Eduardo Lingüística funcional: teoria e prática. Rio de Janeiro: Faperj/DP\&A, 2003.

MATTHEWS, P.H. Oxford Concise dictionary of Linguistics. Oxford University Press, 2005.

MATURANA, H. Biologia do conhecer e epistemologia. In MAGRO, C. e PAREDES, V. (org.) Cognição, ciência e vida cotidiana. Belo Horizonte: Editora UFMG, 2001.

MEILLET, Antoine. Linguistique historique et linguistique générale. Paris: Libraire Honoré Champion, 1965 [1912].

MENDONZA, Francisco José Ruiz de \& BAICCHI, Annelisa. Illocutionary constructions: Cognitive motivation and linguistic realization. In: KECSKÉS, István \& HORN, Laurence H. Explorations in pragmatics: linguistic, cognitive and intercultural aspects. Berlin: Mouton de Gruyter, 2007 (p. 95-128).

MITHEN, S. J. Thoroughly mobile minds. New Scientist, 178, 2003, pp. 40-41.

NEVES, Maria Helena de Moura. A gramática funcional. São Paulo: Martins Fontes, 1997.

Gramática de usos do português. São Paulo: Editora Unesp, 2000.

NOËL, D. Diachronic construction gramar and grammaticalization theory. In: Functions of Language. USA: John Benjamins Publishing Company, 2007.

NOGUEIRA, Priscilla de Almeida. Correlação entre gramaticalização e movimentação social - estudo do item "meio" na cidade de São Paulo. In: LIMA-HERNANDES, Maria Célia Pereira. (Org.). Gramaticalização em Perspectiva: cognição, textualidade e ensino. São Paulo: Paulistana, 2010 (p. 197-217).

NOGUEIRA, Priscilla de Almeida. Relatório Parcial entregue à Fapesp. 2013.

NUYTS, Jan. Epistemic Modality, Language and Conceptualization: A Cognitive Pragmatic Perspective. John Benjamins Publishing Company, 2001.

PASCHOALIN, Maria Aparecida; SPADOTO, Neuza Terezinha. Gramática: teoria e exercícios. FTD: São Paulo, 2008. 
PAUL, Hermann. Princípios Fundamentais da história da língua. Lisboa: Fundação Calouste Gulbenkian, 1966 - Tradução de Maria Luisa Schemann.

PAULA, F.V. de \& LEME, M. I. S. O Paradigma da aprendizagem implícita e explícita: uma visão integradora das formas de aprender. Psicologia em Pesquisa (UFJF), 2010.

PEIRCE, C. S. In: BUCHLER, J. (ed.) The philosophy of Peirce. N. York: Harcourt and Brace, 1940.

PINKER, Steven. Do que é feito o pensamento. São Paulo: Companhia das Letras, 2008[2007].

SAFFRAN, J. R.; ASLIN, R. N.; \& Newport, E. L. Statistical learning by 8-month-old infants. Science, 274, 1996. (p. 1926-1928)

. Statistical learning of tone sequences by human infants and adults. Cognition, 10, 1999. (p. $27-52$ )

\& WILSON, D. P. From syllables to syntax: Multilevel statistical learning by 12-month-old infants. Infancy, 4, 2003. (p. 273-284)

SAID ALI, M. Gramática histórica da língua portuguesa. 3.ed. São Paulo: Melhoramentos, 1964.

SALOMÃO, Maria Margarida. Razão, realismo e verdade: o que nos ensina o estudo sociocognitivo da referência. In KOCH, Ingedore Villaça; MORATO, Edwiges Maria; BENTES, Anna Christina. Referenciação e discurso. São Paulo: Contexto, 2005.

SARAIVA, F.R. dos Santos. Novíssimo Dicionário Latino-Português. 12a ed. Livraria Garnier: Belo Horizonte, 2006, p. 989.

SEARLE, John. What is language: Some preliminary remarks. In: KECSKES \& HORN. Explorations in Pragmatics: linguistic, cognitive and intercultural aspects. Berlin: Mouton de Gruyter, 2007.

SILVEIRA, Elisabeth. Relevância em narrativas orais. Tese de Doutorado em Lingüística. Rio de Janeiro: UFRJ, 1990.

SKINNER, B. F. Verbal learning. New York: Appleton-Century-Croft, 1957.

SPELKE, Elizabeth S; BREINLINGER, Karen; MACOMBER, Janet; JACOBSON, Kristen. Origins of Knowledge. In: Psychological Review, vol. 99, no 4, p. 605-632, 1992.

SWEETSER, Eve E. Grammaticalization and Semantic Bleaching. In: AXMAKER, Shelley; JESSIER, Annie; SINGMASTER, Helen (orgs.) General Session and Parasession on Grammaticalization. Berkeley Linguistics Society, 1988 (pp.389-405).

TARALLO, Fernando. Tempos Linguísticos. Itinerário histórico da Língua Portuguesa. São Paulo: Ática, 1990.

TINBERGEN, Nikolaas. The Curious Behavior of the Stickleback. Scientific American, 187, p. 22-26, 1952. 
TOMASELLO, Michael. The Cultural Origins of Human Cognition. Cambridge, MA: Harvard University Press, 1999.

Origens culturais da aquisição do conhecimento humano. São Paulo: Martins Fontes, 2003.

Origins of human communication. Cambridge: MIT Press, 2008.

TRAUGOTT, Elizabeth. From propositional to textual and expressive meanings: some semantic-pragmatic aspects of grammaticalization. In: LEHMMAN, W., MALKIEL, Y. (eds) Perspectives on historical linguistics. Amsterdam, John Benjamins, 1982, pp. 245271.

On the rise of epistemic meaning: an example of subjectification in semantic change. Langueg, n. 65, 1989, pp. 31-55

From subjectification to intersubjectification. In: Raymond Hickey (eds.). Motives for language change. Cambridge, UK: Cambridge University Press, 2003. p. 124-139.

\& DASHER, Richard. Regularity in semantic change. Cambridge: Cambridge University Press, 2005.

All that he endeavoured to prove was...':On the emergence of grammatical constructions in dialogic contexts. In: Robin Cooper and Ruth Kempson, eds., Language in Flux: Dialogue Coordination, Language Variation, Change and Evolution. London: Kings College Publications, 2008, pp.143-177.

Revisiting subjectification and intersubjectification. In: DAVIDSE, Kristin.

VANDELANOTTE, Lieven; CUYCKENS, Hubert. Subjectification, Intersubjectification and Grammaticalization. Berlin: De Gruyter Mouton, 2010 (p. 29$70)$.

TRAVAGLIA, L. C. Ensino de língua materna - gramática e texto: alguma diferença? In: Gramática: ensino plural. São Paulo: Cortez, 2003.

TROUSDALE, Graeme. Words and constructions in grammaticalization: the end of the English impersonal construction. In: FITSMAURICE, Susan; ,MINKOVA, Donka. (ed.) Studies in the History of the English Language IV: Empirical and analytical advances in the study of English language change. (Topics in English Linguistics; 61). Berlin/New York: Mouton de Gruyter, 2008, (p. 301-326).

VERHAGEN, Arie. Constructions of Intersubjectivity. Oxford: Oxford University Press, 2005.

VLCEK, Nathalie Pires. Gramaticalização e ordenação de advérbios em -mente/ment no português e no francês: uma análise histórica. Dissertação de Mestrado apresentada ao Programa de Pós-Graduação em Linguística da Universidade Federal do Rio de Janeiro, 2011. 
VOSSLER, KARL. Las formas gramaticales y psicológicas dei Linguaje. In: Introducción a la Estilística romance, p. 17 ss., em Filosofia del lenguaje, Buenos Aires Instituto de Filologia, 1942, p. 131 - 183.

VOTRE, S. Leitura, alfabetização e pragmática lingüística. Perspectiva (Erexim), Florianópolis, v. 17, 1999.

87).

A integração das objetivas diretas. In: Cadernos do CNFL, v. 2: 2000 (p.71-

WERNER, H., \& KAPLAN, B. Symbol formation: An organismic developmental approach to language and the expression of thought. NY: John Wiley, 1963.

WILLETT, T. A. Cross-linguistic survey of grammaticalization of evidentiality. Studies in Language, v. 12, n. 1, p. 51-97, 1988.

WITTGENSTEIN, L. Usage-Based Linguistics. In: TOMASELLO, M. Constructing a Language. A Usage-Based Theory of Language Acquisition. USA: Harvard, 2003.

\section{Base de Dados - Amostras}

BARBOSA, Afranio G. \& LOPES, Célia Regina dos S. Críticas, queixumes $e$ bajulações na Imprensa Brasileira do séc. XIX: cartas de leitores e cartas de redatores. Rio de Janeiro: Projeto PHPB-Rio/FAPERJ. Edição Eletrônica, 2004.

Críticas, queixumes e bajulações na Imprensa Brasileira do séc. XIX: cartas de leitores. Rio de Janeiro: UFRJ, Pós-Graduação em Letras Vernáculas: FAPERJ, 2006.

CETENFolha. Disponível em: <http://www.linguateca.pt/cetenfolha/index_info.html>. Data de acesso: 07/10/2013.

COMVEST (Comissão Permanente para os Vestibulares da Unicamp). Disponível em: <www.comvest.unicamp.br>. Data de acesso: 11/03/2011.

DISSERTAÇÕES E TESES USP. Disponíveis em: 〈www.dedalus.usp.br〉. Data de acesso: 02/09/2013.

DOMÍNIO PÚBLICO. Disponível em: <http://www.dominiopublico.gov.br>. Data de acesso: $15 / 04 / 2014$.

FUVEST (Fundação Universitária para o Vestibular). Disponível em: <www.fuvest.br>. Data de acesso: 11/03/2011. 
Esse gênero compreende 24 espécies descritas, encontradas QUASE em sua totalidade em ambientes de Floresta Atlântica, exceto por H. otavioi (mata rupestre), e sempre associadas a rios e riachos em terrenos acidentados, distribuídas do Espírito Santo ao Rio Grande do Sul. (FACULDADE DE FILOSOFIA, LETRAS E CIÊNCIAS HUMANAS, 2013)

De acordo com esta abordagem interdisplinar, o presente trabalho apoia-se no estudo de objetos metálicos encontrados no Arraial de São Francisco Xavier da Chapada, sítio arqueológico localizado no Mato Grosso, inserido no contexto da mineração colonial do século XVIII e, formado, QUASE que em sua totalidade, por escravos. (MUSEU DE ARQUEOLOGIA E ETNOLOGIA, 2013)

Concluiu-se que: a) a mortalidade das ninfas de M. fimbriolata criadas em Panicum maximum cv. Paredão é QUASE total, podendo tal material ser caracterizado como resistente ao inseto por antibiose; (ESCOLA SUPERIOR DE AGRICULTURA "LUIZ DE QUEIROZ”, 2013)

No Brasil, um dos exemplos dessa diluição, motivada principalmente pela morosidade processual ligada à tradição e cultura nacionais que nutrem certa simpatia pelos recursos, é a Lei de Arbitragem por meio da qual se conferiu aos tribunais arbitrais uma natureza QUASE judicial, iniciativa pioneira dos sistemas de common law. (FACULDADE DE DIREITO, 2013)

Dentre os títulos dedicados à vida do escritor russo destaca-se Dostoiévski de Joseph Frank, um grande esforço de investigação elaborado ao longo de QUASE três décadas. (FACULDADE DE FILOSOFIA, LETRAS E CIÊNCIAS HUMANAS, 2013)

A voz é a principal ferramenta de comunicação da espécie humana e QUASE 70\% da população economicamente ativa dos países desenvolvidos dependem direta ou indiretamente dela em sua profissão. (ESCOLA DE ENGENHARIA DE SÃO CARLOS, 2013)

Neste trabalho procuraremos contornar estes problemas através da utilização do método QUASE-experimental de regressão descontínua. (FACULDADE DE FILOSOFIA, LETRAS E CIÊNCIAS HUMANAS, 2013)

Foi realizado um estudo longitudinal, prospectivo, não-randomizado, aberto e controlado (QUASE-experimental) no qual foram avaliados marcadores ecográficos de avaliação arterial (função e estrutura). (FACULDADE DE MEDICINA, 2013)

A cultura da soja é cultivada em QUASE todo o território nacional, sendo a de maior área de cultivo no Brasil. (ESCOLA SUPERIOR DE AGRICULTURA "LUIZ DE QUEIROZ”, 2013)

Como a simples tradução dessa obra já oferece, por si mesma, uma visão QUASE que satisfatória e integral a respeito da fisionomia entre os letrados árabes, o estudo anexado à presente tradução visa apresentar o desenvolvimento desta arte, expondo algumas semelhanças existentes entre os antigos filósofos árabes que abordaram o tema, e seus 
semelhantes em outras culturas, principalmente a grega. (FACULDADE DE FILOSOFIA, LETRAS E CIÊNCIAS HUMANAS, 2013)

Nós observamos a transferência de população do estado QUASE molecular $\mathrm{nD}+\mathrm{nD}$ para o estado $(n+2) P$ após excitação pulsada na região de $29 \leq n \leq 41$ em uma amostra de $\mathrm{Rb}$ aprisionada em uma armadilha magneto-óptica. (INSTITUTO DE FÍSICA, 2013)

Espera-se que, ao longo do tempo, essas subunidades se comportem como corpos QUASE rígidos e os movimentos destas regiões rígidas correspondam a uma maior representatividade da transição alostérica. (INSTITUTO DE MATEMÁTICA E ESTATÍSTICA, 2013)

Para a nasalidade, notou-se confiabilidade intrajuiz perfeita ou QUASE perfeita (Kappa=1,0), em todas as análises. A concordância interjuizes variou de substancial a perfeita ou QUASE perfeita (Kappa entre 0,715 e 1,0). (FACULDADE DE MEDICINA, 2013)

Por sua vez, a fotólise da enrofloxacina mostrou-se eficiente somente na presença do composto bio-orgânico CVT 230 (BOS C), com remoção de ENRO de QUASE 90\% em meio neutro (pH 7). (ESCOLA POLITÉCNICA, 2013)

Pobreza, violência, guerra e sofrimento estão presentes nas pautas dos meios de comunicação de forma QUASE cinematográfica. Assim, a mídia contribui para espetacularizar a vida humana. (FACULDADE DE FILOSOFIA, LETRAS E CIÊNCIAS HUMANAS, 2013)

Os equipamentos públicos QUASE não aparecem nestas procuras por redes sociais. (INSTITUTO DE PSICOLOGIA, 2013)

A anemia é considerada um dos maiores problemas de saúde pública da atualidade, afetando as populações de QUASE todos os países, sobretudo aqueles onde predominam padrões dietéticos deficientes e fatores ambientais adversos. (FACULDADE DE SAÚDE PÚBLICA, 2013)

Foram analisadas a proliferação, morte e ciclo celular, além da formação e diferenciação de neuroesferas, utilizando, em QUASE todas as etapas, a citometria de fluxo. (FACULDADE DE MEDICINA, 2013)

A análise das informações indicou-nos que a maioria dos alunos atendidos nas Salas de recursos em 2011 era composta por aqueles com deficiência intelectual sendo que havia mais estudantes do sexo masculino $(60,52 \%)$ e que, em QUASE todos os tipos de deficiência e Transtorno global de desenvolvimento, registrou-se mais meninos atendidos do que meninas. (FACULDADE DE EDUCAÇÃO, 2013)

Apesar do reconhecimento unânime de seus pares, arquitetos e artistas, é um arquiteto mineiro QUASE desconhecido para a história da arquitetura brasileira. (FACULDADE DE ARQUITETURA E URBANISMO, 2013)

O total de gasto social do governo somou cerca de $\mathrm{R} \$ 800$ bilhões em 2009, QUASE 25\% do PIB brasileiro. (ESCOLA SUPERIOR DE AGRICULTURA “LUIZ DE QUEIROZ", 2013) 
Uma das preocupações que tem sido apontadas ultimamente é a QUASE inexistência de base de dados pública de expressões matemáticas, o que dificulta o desenvolvimento e comparação de diferentes abordagens. (INSTITUTO DE MATEMÁTICA E ESTATÍSTICA, 2013)

Simulações dinâmicas também vieram comprovar que o modelo opera com deslocamentos de 30 'mü'm e frequências de até $700 \mathrm{~Hz}$ utilizando o material de construção do PFA 'AL' 7075, com QUASE nenhuma histerese. (ESCOLA DE ENGENHARIA DE SÃO CARLOS, 2013)

O câncer de colo uterino é o segundo tipo de câncer mais comum entre as mulheres brasileiras e está relacionado QUASE que exclusivamente à infecção persistente pelo papiloma vírus humano (HPV) de alto risco oncogênico. (FACULDADE DE MEDICINA, 2013)

As práticas não saudáveis para controle do peso foram QUASE três vezes mais prevalentes e evidenciou-se que estas práticas aumentam o risco de desenvolver comportamentos mais graves. (FACULDADE DE SAÚDE PÚBLICA, 2013)

Isso foi devido as plantas estarem com porte baixo e o solo estar QUASE por completo exposto as variações atmosféricas, fazendo com que as taxas de E e Ke sejam superiores as de T e Kcb. (ESCOLA SUPERIOR DE AGRICULTURA “LUIZ DE QUEIROZ”, 2013)

Sabe-se que a grande maioria dos fitopatógenos depende QUASE que exclusivamente de vetores para disseminarem-se para novos hospedeiros, porém pouco foi estudado no que se refere aos efeitos dos micro-organismos sobre seus insetos vetores. (ESCOLA SUPERIOR DE AGRICULTURA “LUIZ DE QUEIROZ”, 2013)

Em reaquecimento, a NR das folhas teve seu ritmo atrasado em todas as situações, com exceção quando o frio foi aplicado no início da fase escura, na qual houve perda QUASE completa de variação ao longo do dia. (INSTITUTO DE BIOCIÊNNCIAS, 2013)

Não fosse assim um agrupamento de parlamentares descontentes com o andamento dos trabalhos constituintes não teria insurgido com uma proposta para a reformulação do Regimento Interno após QUASE um ano de funcionamento. (FACULDADE DE FILOSOFIA, LETRAS E CIÊNCIAS HUMANAS, 2013)

QUASE 70\% dos cenários climáticos geraram, no modelo transiente, variações dos níveis freáticos abaixo daqueles medidos no monitoramento entre $2004 \mathrm{e}$ 2011. (ESCOLA DE ENGENHARIA DE SÃO CARLOS, 2013)

Nosso protocolo permite o cálculo de todos os estados da rede protegidos de uma só vez, assim como leva naturalmente ao conceito de subespaço QUASE livre de decoerência (SQLD), dentro do qual um estado de superposição é QUASE completamente protegido. (...) Em seguida desenvolvemos um protocolo para transferência QUASE perfeita de estados de poláriton de um sistema emissor para um receptor, separados espacialmente (...) Demonstramos que a incoerência decorrente das não idealidades quânticas do canal é QUASE totalmente contornada pelo mecanismo de tunelamento que possibilita um processo de transferência de alta fidelidade. (INSTITUTO DE FÍSICA, 2013) 
Os resultados demonstram que os indicadores que compõe o modelo de avaliação são QUASE sempre e sempre utilizados pelas CEs, com níveis de uso variando de 0,49 a 0,87 de uma escala de zero a um. (FACULDADE DE ECONOMIA, ADMINISTRAÇÃO E CONTABILIDADE, 2013)

Mas como compreendê-la em um cenário atual no qual: a) as condições tecnológicas permitem que qualquer cidadão, a um custo baixo ou QUASE inexistente, publique informações para um número indistinto de pessoas, (...) (FACULDADE DE DIREITO, 2013)

As doenças cardiovasculares são responsáveis por QUASE um terço da mortalidade global, atualmente com incidência e prevalência significativas e crescentes entre os países desenvolvidos e em desenvolvimento. (...) Nesse contexto, a projeção de aumento total no número de mortes por causas cardiovasculares, no Brasil, entre 2000 e 2040, é especialmente preocupante, quando comparada a outros países, chegando a QUASE 250\%. (FACULDADE DE MEDICINA, 2013)

Nesta pesquisa, desenvolvem-se formulações não lineares do MEC para a análise da propagação de fissuras em materiais QUASE frágeis. (ESCOLA DE ENGENHARIA DE SÃO CARLOS, 2013)

A Estação Ecológica de Caetetus possui um dos mais significativos remanescentes da Floresta Estacional Semidecidual que revestia QUASE todo o interior do estado de São Paulo, parte de Minas Gerais, Mato Grosso do Sul, Paraguai e Argentina. (ESCOLA SUPERIOR DE AGRICULTURA “LUIZ DE QUEIROZ”, 2013)

A reprodutibilidade da escala modificada do MRC, usando-se o AC2 coeficiente foi (0, 81 - 1) muito boa (Altman, 1991) ou QUASE - perfeita (FACULDADE DE MEDICINA, 2013)

Já nos animais adultos, verificou-se maior semelhança ao perfil dos camundongos controles normais da mesma idade, com exceção do gene Large que apresentou expressão diminuída em QUASE todos os animais em estudo. (INSTITUTO DE BIOCIÊNCIAS , 2013)

Representantes de QUASE todas as subfamílias de Libellulidae, assim como de todos os gêneros de 'Sympetrinae' foram incluídos, totalizando 69 táxons terminais. (...) enquanto Erythemis demonstrou ser parafilético emQUASE todas as árvores contrariando resultados anteriores (INSTITUTO DE BIOCIÊNCIAS, 2013)

Além de ser previsto em lei, o tratamento da fração orgânica se faz necessário já que no Brasil são gerados QUASE 100 mil toneladas por dia de resíduos orgânicos. A maioria desses resíduos é atualmente disposta em aterros sanitários. (ESCOLA DE ENGENHARIA DE SÃO CARLOS, 2013)

(...) e experimentais que mostram a capacidade do sistema de geração em transferir potência constante para a rede de distribuição e manter a corrente QUASE sem distorções (ESCOLA DE ENGENHARIA DE SÃO CARLOS, 2013)

(...) um decréscimo de QUASE 80\% na riqueza de táxons e na densidade total da comunidade bentônica quando comparada com a comunidade no controle (ESCOLA DE ENGENHARIA DE SÃO CARLOS, 2013) 
Porém, QUASE nenhuma dessas técnicas explora o fato que existem funções custo cujos valores são estimados a partir de uma amostra e que descrevem uma "curva em U" nas cadeias do reticulado Booleano (P(S); (INSTITUTO DE MATEMÁTICA E ESTATÍSTICA, 2013)

Desde seu nascimento, há QUASE trinta anos, o Movimento dos Trabalhadores Rurais Sem Terra (MST) tem se destacado pela perenidade de sua organização (FACULDADE DE FILOSOFIA, LETRAS E CIÊNCIAS HUMANAS, 2013)

O alijamento é um instituto próprio do Direito Marítimo (romano). Trata-se do arremesso de mercadorias ou instrumentos da embarcação a fim de salvar ambas do naufrágio. Seu efeito é a repartição de danos entre os envolvidos (contributio), a qual caracteriza, com o tempo, as avarias grossas. No Digesto, é possível encontrar (QUASE) todos os elementos que o constituem. (FACULDADE DE DIREITO, 2013)

Identificou-se que esses impactos promovem aumentos em QUASE todos os agregados macroeconômicos, em especial os choques causados pelo biodiesel. (ESCOLA SUPERIOR DE AGRICULTURA “LUIZ DE QUEIROZ”, 2013)

Em seu estudo no escalamento, verificou-se uma diminuição no tempo de retenção para canais mais curtos (QUASE 2 ordens de grandeza), demonstrando ser um fator limitante para as futuras gerações das memórias 1T-DRAM. Apesar disso, quando comparados com os dispositivos convencionais com extensão de fonte e dreno (com extensão), seu tempo de retenção aumentou (QUASE 1 ordem de grandeza), permitindo a utilização de menores (...) (ESCOLA POLITÉCNICA, 2013)

Trata-se de um estudo prospectivo e autocontrolado (QUASE experimental). (FACULDADE DE MEDICINA, 2013)

(...) indica que a maior representatividade em termos de consumo de energia primária, se dá pela eletricidade com QUASE 85\%, enquanto a emissão de CO2 representada pelo gás natural é de 43\%. (ELTROTÉCNICA, 2013)

Em relação à confiabilidade inter-avaliadores (AV1 e AV2), obteve-se concordância QUASE perfeita para o GMFCS E \& R e MACS $(K=0,902$ e 0,90 respectivamente), assim como intra-avaliadores, obtendo-se concordância QUASE perfeita para ambos avaliadores acerca do GMFCS E \& R $(\mathrm{k}=1,00)$ (FACULDADE DE MEDICINA, 2013)

Estereótipos QUASE não foram observados, totalizando somente $0,45 \%$ dos comportamentos totais, indicando um baixo nível de stress. (ESCOLA SUPERIOR DE AGRICULTURA “LUIZ DE QUEIROZ”, 2013)

o ditongo [eU ] teve baixo índice de ocorrência de monotongação, sendo mantido em QUASE todos os contextos (FACULDADE DE FILOSOFIA, LETRAS E CIÊNCIAS HUMANAS, 2013)

Da "La Chasse-Galerie" à Canoa Voadora: QUASE a mesma lenda: leitura sob o olhar de um brasileiro. (....) Para atingir esse objetivo, tomamos por base os conceitos teóricos de Eco (2007) sobre a tradução que afirma que quando se traduz nunca se diz a mesma coisa, mas QUASE e Berman (2002) (...) (FACULDADE DE FILOSOFIA, LETRAS E CIÊNCIAS HUMANAS, 2013) 
A estratégia de busca envolveu qualquer referência indexada entre 1 de Janeiro de 1992 e 01 de Janeiro de 2012, os critérios de inclusão foram os ensaios clínicos randomizados e QUASE randomizados envolvendo o tratamento de deformidades nas mãos devido à doença de Dupuytren (FACULDADE DE MEDICINA, 2013)

(...) os sistemas jurídicos da Inglaterra e dos Estados Unidos da América projetaram meios bastante diferentes, QUASE opostos, para preservar o núcleo de suas respectivas Constituições. (FACULDADE DE DIREITO, 2013)

O linfoma difuso de grandes células B é o mais freqüente grupo de linfoma nãoHodgkin, perfazendo QUASE50\% dos casos no serviço de hematologia do Hospital das Clínicas da Faculdade de Medicina da Universidade de São Paulo e Instituto do Câncer do Estado de São Paulo. (FACULDADE DE MEDICINA, 2013)

Depois QUASE seis anos e ensaios e preparações, figurinos, objetos de cena e cenários criados especialmente para a peça (FACULDADE DE FILOSOFIA, LETRAS E CIÊNCIAS HUMANAS, 2013)

Ao investigar a construção e a medida da tolerância em Pierre Bayle, bem como suas implicações especialmente para a política e para o direito, a intenção é mostrar que a obra bayliana contém uma teoria política que não está sistematizada, mas, como QUASE todos os grandes temas dos escritos de Bayle, disseminada por vários textos. (FACULDADE DE FILOSOFIA, LETRAS E CIÊNCIAS HUMANAS, 2013)

(...) as cantigas de maldizer, os satíricos barrocos, Bocage, Camilo Pessanha, Mário de Sá-Carneiro e Al Berto representam as produções grotescas de suas épocas e participam, em QUASE todos os casos, do cânone literário português. (FACULDADE DE FILOSOFIA, LETRAS E CIÊNCIAS HUMANAS, 2013)

A formulação convencional do Método dos Elementos Finitos (MEF) baseada em aproximação do campo de deslocamentos apresenta limitações conhecidas como, por exemplo, em problemas que envolvam regiões com singularidade e problemas de elasticidade QUASE incompressível. (...) Isto se dá porque os critérios de danificação empregados são QUASE sempre baseados na estimativa do campo de tensões atuantes. (ESCOLA DE ENGENHARIA DE SÃO CARLOS, 2013)

(...) local ruim destinado à coleta de escarro; QUASE sempre há disponibilidade suficiente de profissionais; às vezes tem sobrecarga de trabalho; (...) não tem pote para coleta de escarro; tem equipamento de Raio-x; local muito ruim destinado à coleta de escarro; QUASE nunca há disponibilidade suficiente de profissionais; sempre tem sobrecarga de trabalho; não solicitam baciloscopia (...) (ESCOLA DE ENFERMAGEM, 2013)

Isto implicava, pois, o reconhecimento das oscilações que o mundo romano teria vivenciado ao longo de QUASE quatro séculos e as contradições que animavam a conduta das personagens históricas. (FACULDADE DE FILOSOFIA, LETRAS E CIÊNCIAS HUMANAS, 2013)

Ao entrar em contato com a água e sofrer amassamento mecânico, a farinha de trigo tem a propriedade, QUASE exclusiva, de produzir uma massa coesa e viscoelástica (INSTITUTO DE QUÍMICA, 2012) 
No que se refere às realizações arquitetônicas e urbanísticas, a fase brasileira de Jan Bata, por sua QUASE total ausência na historiografia, ainda carece de melhor conhecimento e análise. (ESCOLA DE ENGENHARIA DE SÃO CARLOS, 2012)

(...) ausência QUASE total de usos significativos (FACULDADE DE FILOSOFIA, LETRAS E CIÊNCIAS HUMANAS, 2012)

Houve a formação de dois ramos principais, um constituído QUASE que exclusivamente por amostras de A. sp.1, e apenas duas amostras de A. sp.3, e outro que reuniu todas as espécies do complexo. (INSTITUTO DE BIOCIÊNCIAS, 2012)

Dados sobre violência psicossocial de inúmeros orgãos, pesquisas acadêmicas no assunto, e a própria preocupação manifesta de autoridades governamentais de segurança pública tornam QUASE que inevitável que essas discussões vinculem a polícia à violência. (INSTITUTO DE PSICOLOGIA, 2012)

A análise dos dados aponta para o fato de que, quando uma criança tem a possibilidade de experimentar eventos de letramento em sua primeira infância, essas vivências a conduzem por um processo de alfabetização sem grandes dificuldades, entretanto, a análise dos dados também nos indica que, embora este processo se desenvolva QUASE que naturalmente, alguns sujeitos da pesquisa fogem a ele, o que nos permite vivenciar uma riqueza de possibilidades própria da diversidade humana (...) (FACULDADE DE EDUCAÇÃO, 2012)

(...) mostrou que o OLAM v3.3 subestima a energia do sinal intrasazonal na região do oceano Índico em QUASE a metade do valor real observado. (INSTITUTO DE ASTRONOMIA, GEOINSTITUTO DE FÍSICA E CIÊNCIAS ATMOSFÉRICAS, 2012)

Assim, do ponto de vista instrumental, elementos como textura, estilo de acompanhamento e conceito de condução de vozes, para citar apenas alguns aspectos, sofreram mudanças de concepção, resultando muitas vezes QUASE em uma nova composição e, até mesmo, outra percepção da forma musical. (ESCOLA DE COMUNICAÇÃO E ARTES, 2012)

A partir da análise pudemos entender que a demanda em saúde mental é constante no serviço e que essa vem, QUASE sempre, acompanhada de uma angústia (...) sendo que os demais profissionais da equipe, QUASE sempre, se limitam apenas executar prescrições médicas (ESCOLA DE ENFERMAGEM, 2012)

Apesar deter sido documentada há QUASE 80 anos, sua etiologia continua desconhecida até os dias de hoje. (FACULDADE DE MEDICINA, 2012)

Estes pequenos sambaquis, QUASE sempre, não acompanham o processo formativo modelado para os grandes sambaquis da região (e.g. Jab II) (MUSEU DE ARQUEOLOGIA E ETNOLOGIA, 2012)

Este trabalho analisa três peças de Brian Friel - The Enemy Within (1962), Faith Healer (1979) e Dancing at Lughnassa (1990) escritas em um intervalo de QUASE trinta anos. (FACULDADE DE FILOSOFIA, LETRAS E CIÊNCIAS HUMANAS, 2012) 
QUASE a totalidade dos familiares afirmou que a chegada da criança foi bem aceita pela família, e a maioria considerou importante incluir essa questão na consulta de sáude da criança. (...) acima de $90 \%$ afirmaram que também consideram importante a inclusão desse tema na consulta, e QUASE todas reconhecem como importante para a criança ter um bom acompanhamento de saúde. (...) QUASE a totalidade das justificativas apontam para o entendimento pelo profissional como elemento norteador da conduta para o bom cuidado da criança. Conclusão: a maioria dos familiares realiza o cuidado, mesmo que alguns deles não sejam compreendidos como fundamentais para o desenvolvimento infantil. (ESCOLA DE ENFERMAGEM, 2012)

O consumo excessivo de carne foi observado em QUASE 75por cento das pessoas e o tipo de carne mais consumido nos dois períodos foi a bovina (FACULDADE DE SAÚDE PÚBLICA, 2012)

A reavaliação dos pacientes, após a introdução da medicação determinou melhora em QUASE todos os parâmetros, exceto em relação ao número e tipo de erros na recontagem da estória. (FACULDADE DE MEDICINA, 2012)

A viabilidade para o período ovo adulto foi QUASE duas vezes superior à viabilidade obtida na dieta natural, sendo de $68 \%$ em relação aos $38 \%$ obtidos na dieta natural (ESCOLA SUPERIOR DE AGRICULTURA “LUIZ DE QUEIROZ”, 2012)

Ainda que estabelecidos à margem de um programa comum com objetivos coordenados, os desafios apresentados a partir do Mercosul Cultural levaram a iniciativas que tecem redes e têm instalado circuitos para ocupar o espaço QUASE vazio de trânsito cultural entre os países mercosulinos (FACULDADE DE FILOSOFIA, LETRAS E CIÊNCIAS HUMANAS, 2012)

Desenhado a partir de fragmentos de QUASE um século, o caráter do estudo é em primeiro lugar de natureza histórica. (FACULDADE DE ARQUITETURA E URBANISMO, 2012)

Pacientes caminhando, menos de 235 metros no teste de caminhada, QUASE certamente expressarão insatisfação marcante em relação à sua QV. (FACULDADE DE MEDICINA, 2012)

Episódios de atenção conjunta, portanto, podem QUASE ser denominados de episódios de atenção visual conjunta. (FACULDADE DE MEDICINA, 2012)

(...) foi possível analisar, no segundo QUASE experimento indícios, mesmo que não conclusivos (FACULDADE DE ECONOMIA, ADMINISTRAÇÃO E CONTABILIDADE, 2012)

Nele discutem-se os conceitos de prole futura, prole eventual e concepturo, sua natureza jurídica, os direitos que lhe podem ser atribuídos, sob condição, e as consequências verificadas nos procedimentos de inventários e partilhas, com base na doutrina brasileira - muito escassa e no direito estrangeiro, QUASE inexistente. (FACULDADE DE DIREITO, 2012)

Em 2004 ocorreram poucos casos no município, enquanto de 2005 a 2007 a doença se espalhou por QUASE toda a cidade. (FACULDADE DE MEDICINA, 2012) 
(...) deixando diversas pendências sociais e fundiárias ainda sem resolução, inclusive sem elaboração dos planos de manejos das UCs, após QUASE cinco anos da criação do MOJAC. (FACULDADE DE FILOSOFIA, LETRAS E CIÊNCIAS HUMANAS, 2012)

A hipótese não é rejeitada, observando-se um efeito positivo da segregação para brancos e amarelos e, negativo para negros, fato que se relaciona com a QUASE inexistência de pretos e pardos em escolas particulares (FACULDADE DE ECONOMIA, ADMINISTRAÇÃO E CONTABILIDADE, 2012)

Aplica-se a transformação de coordenadas auto-adaptativa de Telles para a avaliação das integrais QUASE-singulares. (ESCOLA DE ENGENHARIA DE SÃO CARLOS, 2012)

Tiveram acompanhamento no pré-natal $91,4 \%$ das mulheres, $55,1 \%$ das quais se consultaram de uma a seis vezes. QUASE a totalidade apresentou algum tipo de afecção durante a gestação: (...) A QUASE totalidade dos partos (ESCOLA DE ENFERMAGEM, 2012)

A infraestrutura para abrigar os resíduos de serviços de saúde dentro das normas técnicas nos estabelecimentos geradores é QUASE inexistente (ESCOLA DE ENGENHARIA DE SÃO CARLOS, 2012)

O tipo de sistema de circulação de células utilizado não influenciou estatisticamente QUASE nenhuma das respostas estudadas e isto indica a possibilidade de substituição do sistema tradicional airlift pelos outros testados neste trabalho. (INSTITUTO DE QUÍMICA, 2012)

QUASE 3 bilhões de pessoas vivem em áreas tropicais de risco de infecção com uma das 5 espécies evidenciando um problema mundial carente de solução imediata. (INSTITUTO DE BIOMÉDICAS, 2012)

(...) é um teste que já foi traduzido e adaptado à população brasileira há QUASE três décadas (FACULDADE DE MEDICINA, 2012)

Esta pesquisa reconhece a existência de sinonímia e QUASE-sinonímia (FACULDADE DE FILOSOFIA, LETRAS E CIÊNCIAS HUMANAS, 2012)

Isso pode ocorrer em algumas condições de lançamento, em que sua estrutura pode se configurar de forma QUASE vertical. (ESCOLA POLITÉCNICA, 2012)

Fazem com que o problema seja QUASE onipresente em todas as cidades, indistintamente do seu porte ou condições climáticas ou hidrogeológicas. (INSTITUTO DE GEOCIÊNCIAS, 2012)

Para todos os filmes com amido gelatinizado, a adição de polióis aumenta a temperatura de pico endotérmico e esta é QUASE sempre maior quando o glicerol é adicionado (INSTITUTO DE QUÍMICA, 2012)

(...) praticamente todos os flavonóides foram detectados em QUASE todas as amostras, com exceção do Caempferol, (ESCOLA SUPERIOR DE AGRICULTURA "LUIZ DE QUEIROZ”, 2012) 
O estudo dos pontos singulares em campos sensoriais analíticos é um problema QUASE completamente resolvido. (INSTITUTO DE MATEMÁTICA E ESTATÍSTICA, 2012)

Tanto a análise para colágeno tipo I quanto a análise para elastina apontaram um aumento de QUASE 20\% em relação às amostras não tratadas, (FACULDADE DE FILOSOFIA, LETRAS E CIÊNCIAS HUMANAS DE RIBEIRÃO PRETO, 2012)

QUASE trinta anos após a fundação de Israel, que saía de sua terceira guerra em 30 anos de existência. (FACULDADE DE FILOSOFIA, LETRAS E CIÊNCIAS HUMANAS, 2012)

Revelou também que parcela da rotatividade docente até 2010 pode ser vista como estrutural, na medida em que QUASE metade dos professores não tinha vínculo com a escola (FACULDADE DE ECONOMIA, ADMINISTRAÇÃO E CONTABILIDADE, 2012)

Apesar de importantes contribuições recentes de alguns pesquisadores, a QUASE totalidade das espécies de Hypha é conhecida superficialmente. (FACULDADE DE FILOSOFIA, LETRAS E CIÊNCIAS HUMANAS DE RIBEIRÃO PRETO, 2012)

(...) apresentamos o Método das Médias Esféricas, e fazemos uma aplicação da teoria de distribuições QUASE periódicas. (ESCOLA POLITÉCNICA, 2012)

(...) exercícios para tronco e o IMC esteve associado a QUASE todas as variáveis estimadas para analise da FM. (FACULDADE DE MEDICINA, 2012)

(...) foram prevenidas pela inibição da nNOS em QUASE todos os núcleos da base. (FACULDADE DE MEDICINA, 2012)

QUASE metade deles $(\mathrm{n}=23 ; 46 \%)$ tinha renda familiar mensal de quatro saláriosmínimos. (ESCOLA DE ENFERMAGEM, 2012)

(...) semelhantes aos expostos em QUASE todas as produções científicas analisadas: FACULDADE DE EDUCAÇÃO

(...) transmissão da música em busca da oralidade e da subjetividade que QUASE se perdeu. (ESCOLA DE COMUNICAÇÃO E ARTES, 2012)

No entanto, após QUASE15 anos de existência do 3-PG (ESCOLA SUPERIOR DE AGRICULTURA “LUIZ DE QUEIROZ”, 2012)

Os julgamentos de NASO nas emissões papapa e Papai pediu pipoca e os escores de TEAN indicativos de ausência de fechamento velofaríngeo tiveram concordância QUASE perfeita e na emissão (FACULDADE DE ODONTOLOGIA, 2012)

Nesse sentido, há no romance a formação de uma sociedade a partir de valores principalmente africanos, já que África surge como o espaço central da nova era são desse continente, em sua QUASE totalidade, os indivíduos selecionados e ali reconstroem suas vidas e o passado que ficará como História. (FACULDADE DE FILOSOFIA, LETRAS E CIÊNCIAS HUMANAS, 2012) 
Essa polarização está diretamente relacionada à compreensão sobre o modo de solução do conflito entre um princípio e uma regra. Concebidos, QUASE que paradoxalmente, como normas que ordenam que algo seja realizado na maior medida possível dentro possibilidades fáticas e jurídicas existentes (FACULDADE DE DIREITO, 2012)

As críticas levantadas pela doutrina quanto ao instituto da execução de ofício das contribuições previdenciárias na Justiça do Trabalho culminam, QUASE sempre, na decretação de sua inconstitucionalidade (FACULDADE DE DIREITO, 2012)

QUASE perfeita para as diferentes (FACULDADE DE MEDICINA, 2012)

(...) sendo encontradas em QUASE todas a (...) extinta (EX) e Myracrodruon urundeuva como QUASE ameaçada (INSTITUTO DE BIOCIÊNCIAS, 2012)

(...) experimentos QUASE estacionários (...) experimentos QUASE estacionários (INSTITUTO DE QUÍMICA, 2012)

(...) os homicídios começaram a cair QUASE ininterruptamente (FACULDADE DE FILOSOFIA, LETRAS E CIÊNCIAS HUMANAS, 2012)

(...) além de QUASE todos os outputs sociais (ESCOLA DE ENGENHARIA DE SÃO CARLOS, 2012)

Distribuiu-se ao núcleo celular em QUASE todas as células avaliadas (INSTITUTO DE BIOCIÊNCIAS, 2012)

(...) durante QUASE toda a vida desses animais (FACULDADE DE MEDICINA VETERINÁRIA E ZOOTECNIA, 2012)

QUASE todas as espécies apontadas para Eurytellina, (INSTITUTO DE BIOCIÊNCIAS, 2012)

Passadas QUASE duas décadas da adoção da coisa julgada (FACULDADE DE DIREITO, 2012)

(...) utiliza como plantas hospedeiras QUASE exclusivamente espécies da família Asteraceae (FACULDADE DE CIÊNCIAS FARMACÊUTICAS DE RIBEIRÃO PRETO, 2012)

(...) para QUASE todos setores (...) Com mark ups maiores do que dois para QUASE todos setores (FACULDADE DE ECONOMIA, ADMINISTRAÇÃO E CONTABILIDADE, 2012)

(...) que possui QUASE 6.000 neurônios segmentados, foram (INSTITUTO DE FÍSICA, 2012)

QUASE sempre, implica (ESCOLA DE ENFERMAGEM, 2012)

QUASE todos os entrevistados $(98,11 \%)$ iniciaram o tratamento no HRAC/USP antes (FACULDADE DE MEDICINA, 2012)

(...) em QUASE todos os tipos celulares. (INSTITUTO DE BIOMÉDICAS, 2012) 
A dengue emergiu como um grande problema de saúde pública com QUASE metade da população mundial sob risco de infecção. (FACULDADE DE MEDICINA, 2012)

Analisamos o papel do precedente judicial no atual ordenamento, de acordo com a sua carga de eficácia, a saber, vinculante, QUASE vinculante e persuasiva (...) (FACULDADE DE DIREITO, 2012)

A confiança manifesta-se como um QUASE-objeto (MOURITSEN; THRANE, 2006) que ganha existência na circulação de informações entre as partes. (FACULDADE DE ECONOMIA, ADMINISTRAÇÃO E CONTABILIDADE, 2012)

Posteriormente são apresentados ensaios experimentais de relaxação, QUASE-estáticos e dinâmicos de tração (...)A grande quantidade de ensaios QUASE-estáticos (...) QUASE-estáticos e de propagação de ondas em sua parte viscoelástica e a parte plástica dos ensaios QUASE-estáticos juntamente (ESCOLA POLITÉCNICA, 2012)

Citrus tristeza virus (CTV) ocorre em QUASE todas as áreas produtoras de citros do mundo (ESCOLA SUPERIOR DE AGRICULTURA “LUIZ DE QUEIROZ”, 2012)

transversal e de intervenção, com delineamento QUASE experimental pré e pós-teste, (ESCOLA DE ENFERMAGEM, 2012)

QUASE todas as fontes de Caxambu (ENEGIAS NUCLEARES, 2012)

QUASE-experimental, longitudinal e (ESCOLA DE ENFERMAGEM, 2012)

Dantas substituiu QUASE todos os termos cultos (FACULDADE DE FILOSOFIA, LETRAS E CIÊNCIAS HUMANAS, 2012)

por QUASE trinta anos (FACULDADE DE FILOSOFIA, LETRAS E CIÊNCIAS HUMANAS, 2012)

Demonstrou, ainda, a coerência da hipótese, de que o ESC falha, na fase de implementação, ao preocupar-se QUASE que exclusivamente com a cessação da pratica ilícita e com os danos futuros que poderão advir da continuidade da conduta ilícita (FACULDADE DE DIREITO, 2012)

Essas obras foram publicadas entre 1861 e 1889 e abrangem QUASE a totalidade de sua trajetória intelectual e política. (FACULDADE DE FILOSOFIA, LETRAS E CIÊNCIAS HUMANAS, 2012)

(....) consideramos o máximo sobre QUASE todos os grafos de $\mathrm{n}$ vértices e com $\mathrm{m}$ arestas (INSTITUTO DE MATEMÁTICA E ESTATÍSTICA, 2012)

A literatura empírica que buscou investigar os efeitos da independência do banco central sobre os custos de desinflação encontra, QUASE que em sua totalidade, uma relação positiva entre estas duas variáveis, (FACULDADE DE ECONOMIA, ADMINISTRAÇÃO E CONTABILIDADE, 2012)

(...) onde constata que a mesma foi, QUASE sempre (FACULDADE DE FILOSOFIA, LETRAS E CIÊNCIAS HUMANAS, 2012) 
(...) são formados em QUASE todas as condições empregadas (...) resultaram em remoções de QUASE 100 \%, (INSTITUTO DE QUÍMICA, 2012)

(...) objetivo se demonstra dificultoso ou QUASE impraticável, (FACULDADE DE FILOSOFIA, LETRAS E CIÊNCIAS HUMANAS, 2012)

(...) de fato, após QUASE um ano de trabalho (FACULDADE DE FILOSOFIA, LETRAS E CIÊNCIAS HUMANAS, 2012)

(...) QUASE perfeito para todas as variáveis avaliadas (FACULDADE DE ODONTOLOGIA, 2012)

(...) tiveram QUASE 3 vezes a chance de alta clínica (FACULDADE DE MEDICINA, 2012)

(...) composto por quatro domínios, e três possíveis respostas (escores) às questões: nunca (0), às vezes (1) e QUASE sempre (2). (FACULDADE DE ODONTOLOGIA, 2012)

(...) o abandono QUASE completo do sistema de coivara (FACULDADE DE MEDICINA, 2012)

(...) QUASE perfeita entre os entrevistadores, (FACULDADE DE MEDICINA, 2012)

(...) onde a fauna e a flora são QUASE inexistentes (FACULDADE DE ARQUITETURA E URBANISMO, 2012)

Esse método eliminou QUASE que completamente a matriz orgânica, gerando os menores limites de detecção e tornou a introdução da amostra no equipamento mais fácil. (INSTITUTO DE QUÍMICA, 2012)

Nossos resultados indicam que a escolha do marcador foi fundamental para revelar diversidade entre os isolados de S. scitamineum, sendo que o RFLP-tel revelou um fingerprinting de DNA QUASE que específico para cada isolado, sendo assim mais apropriado do que os descritos anteriormente. (ESCOLA SUPERIOR DE AGRICULTURA “LUIZ DE QUEIROZ”, 2012)

(...) possuem baixo nível de escolaridade (QUASE 67\% possuem no máximo o ensino fundamental completo) (ESCOLA DE ENFERMAGEM, 2012)

(...) sendo responsável por QUASE 30\% da colheita mundial. (INSTITUTO DE QUÍMICA, 2012)

(...) este processo foi parcialmente inibido por ciclosporina-A, QUASE totalmente inibido pelo reagente de grupos tiois (FACULDADE DE MEDICINA, 2012)

(...) com margem dorsal QUASE plana (...) com margem dorsal QUASE plana (INSTITUTO DE BIOCIÊNCIAS, 2012)

(....) categoria de obesos de QUASE 3/4 dos indivíduos. (FACULDADE DE MEDICINA, 2012) 
(...) mas também com relação à QUASE invisibilidade das mulheres na memória oral dos homens. (FACULDADE DE FILOSOFIA, LETRAS E CIENCIAS HUMANAS, 2012)

(...) grupo encontrado QUASE exclusivamente neste ecossistema. (ESCOLA SUPERIOR DE AGRICULTURA “LUIZ DE QUEIROZ”, 2012)

(...) em QUASE todos os estados do Brasil. (FACULDADE DE EDUCAÇÃO, 2012)

A tomada de decisão QUASE sempre (INSTITUTO DE PSICOLOGIALOGIA, 2012)

(...) a QUASE 40 anos atrás. (INSTITUTO DE GEOCIÊNCIAS, 2012)

(...) de QUASE 90\% do genoma expresso da cana-de-açúcar (INSTITUTO DE QUÍMICA, 2012)

Identificou-se oscilações QUASE-semi anuais, preponderantes na intensificação dos períodos secos de inverno e pré-estação chuvosa. (INSTITUTO DE PSICOLOGIALOGIA, 2012)

(...) uma QUASE influência em toda a área de estudo, (FACULDADE DE FILOSOFIA, LETRAS E CIÊNCIAS HUMANAS, 2012)

(...) mantém QUASE todo o corpo na horizontal. (FACULDADE DE MEDICINA VETERINÁRIA E ZOOTECNIA, 2012)

(...) durante QUASE todo o século XIX, (FACULDADE DE ARQUITETURA E URBANISMO, 2012)

Trata-se de livros que facilitam conhecimentos e fornecem conselhos práticos aos professores, constituindo QUASE uma literatura de autoajuda pedagógica (FACULDADE DE EDUCAÇÃO, 2012)

(...) QUASE sempre no nível molécula (INSTITUTO DE FÍSICA, 2012)

Para esses sujeitos o ato é QUASE como um dever (INSTITUTO DE PSICOLOGIA, 2012)

(...) em que as afecções tristes estão presentes por QUASE todo o tempo (FACULDADE DE FILOSOFIA, LETRAS E CIÊNCIAS HUMANAS, 2012)

(...) capacidade instalada em operação em QUASE cinco vezes em apenas cinco anos

(...) energia eólica foi a que recentemente obteve maior sucesso, tendo um crescimento de QUASE 15 vezes entre 2000 e 2011 (INSTITUTO DE ELETROTÉCNICA E ENERGIA, 2012)

(...) se mostraram QUASE invariantes com a temperatura, (INSTITUTO DE QUÍMICA, 2012)

Abriga QUASE metade da população do Estado e compreende (FACULDADE DE SAÚDE PÚBLICA, 2012)

(...) a distribuição natural ocorre por QUASE toda a costa leste da Austrália (ESCOLA SUPERIOR DE AGRICULTURA “LUIZ DE QUEIROZ”, 2012) 
Tal representação é alcançada em grande parte através da criação de imagens deformadas do escravo que, embora esteja na base da formação brasileira, QUASE não aparece de modo positivo na literatura da época senão por um viés embranquecedor e somente quando se trata do escravo doméstico. (FACULDADE DE FILOSOFIA, LETRAS E CIÊNCIAS HUMANAS, 2012)

(...) há QUASE duas décadas, (ESCOLA DE ENGENHARIA DE SÃO CARLOS, 2012)

(...) passou-se à QUASE negligência dos aspectos descritivos em favor das representações (INSTITUTO DE QUÍMICA, 2012)

(...) chamamos o processo resultante de processo QUASE-estável (...) o limite de escala é uma QUASE-difusão (INSTITUTO DE MATEMÁTICA E ESTATÍSTICA, 2012)

O contato QUASE que permanente da cavidade bucal com o meio externo torna-a extremamente vulnerável sendo fundamental a presença do cirurgião-dentista na equipe de saúde do trabalhador. (FACULDADE DE ODONTOLOGIA, 2012)

(...) os valores funcionais do grupo sem obstrução QUASE se normalizaram. (FACULDADE DE MEDICINA, 2012)

(...) usando os seguintes métodos de estimação: aproximação de Laplace, quadratura adaptativa de Gauss-Hermite e QUASE-verossimilhança penalizada. (INSTITUTO DE MATEMÁTICA E ESTATÍSTICA, 2012)

(...) QUASE isoladas, sem relações diretas (MUSEU DE ARQUEOLOGIA E ETNOLOGIA, 2012)

(...) QUASE a totalidade do Oriente Médio, (FACULDADE DE FILOSOFIA, LETRAS E CIÊNCIAS HUMANAS, 2012)

QUASE 90\% dos homens após a oitava década. (FACULDADE DE MEDICINA, 2012)

(...) pois QUASE todas as crianças apresentaram risco nessa avaliação. (FACULDADE DE MEDICINA, 2012)

O direito internacional das águas doces, voltado QUASE que exclusivamente para os cursos de água internacionais (INSTITUTO DE ELETROTÉCNICA E ENERGIA, 2012)

(...) destinado à moradia de QUASE 2.500 famílias pode situar (FACULDADE DE FILOSOFIA, LETRAS E CIÊNCIAS HUMANAS, 2012)

No entanto, a versão original do ReMoto foi parametrizada QUASE que totalmente utilizando dados de gatos (ESCOLA POLITÉCNICA, 2012)

QUASE todo o tempo (INSTITUTO DE BIOCIÊNCIAS, 2012)

No Brasil, a QUASE totalidade dos edifícios habitacionais (ESCOLA POLITÉCNICA, 2012) 
(...) em QUASE todos os escores totais e domínios (FACULDADE DE MEDICINA, 2012)

Os resultados obtidos pelo modelo implementado no presente trabalho reproduzem QUASE que exatamente as curvas de resfriamento e a previsão de tamanho de grão médio obtidas por um modelo que considera os grãos apenas de forma média. (ESCOLA POLITÉCNICA, 2011)

(...) de QUASE trinta anos, (FACULDADE DE FILOSOFIA, LETRAS E CIÊNCIAS HUMANAS, 2011)

(...) QUASE todas as variáveis (FACULDADE DE MEDICINA, 2011)

(...) QUASE completo (ESCOLA SUPERIOR DE AGRICULTURA "LUIZ DE QUEIROZ”, 2011)

(...) de perturbação do tipo QUASE não-estacionário, (ESCOLA POLITÉCNICA, 2011)

QUASE idênticos (FACULDADE DE CIÊNCIAS FARMACÊUTICAS DE RIBEIRÃO PRETO, 2011)

(...) e a QUASE unanimidade dos entrevistados (FACULDADE DE CIÊNCIAS FARMACẾUTICAS DE RIBEIRÃO PRETO, 2011)

(...) QUASE duzentos anos sob administração da Companhia das Índias Ocidentais (FACULDADE DE FILOSOFIA, LETRAS E CIÊNCIAS HUMANAS, 2011)

estruturas QUASE eternas (ESCOLA POLITÉCNICA, 2011)

QUASE sempre estudada (FACULDADE DE DIREITO, 2011)

QUASE totalidade dos criptossistemas (ESCOLA POLITÉCNICA, 2011)

em um modelo analítico linear QUASE-geostrófico (INSITUTO INSTITUTO OCEANOGRÁFICO, 2011)

ao desenvolver um QUASE-experimento. (...) QUASE-experimental (FACULDADE DE ECONOMIA, ADMINISTRAÇÃO E CONTABILIDADE, 2011)

QUASE totalmente descrita desde sua descoberta (INSTITUTO DE QUÍMICAS, 2011)

QUASE correto (INSTITUTO DE MATEMÁTICA E ESTATÍSTICA, 2011)

QUASE nunca (INSTITUTO DE PSICOLOGIA, 2011)

QUASE três anos depois (FACULDADE DE FILOSOFIA, LETRAS E CIÊNCIAS HUMANAS, 2011)

QUASE-experimental (FACULDADE DE MEDICINA, 2011)

QUASE todo o ano letivo escolar. (...) QUASE não há espaço para a invenção e para a aprendizagem significativa (FACULDADE DE FILOSOFIA, LETRAS E CIÊNCIAS HUMANAS, 2011) 
QUASE todos docentes (FACULDADE DE FILOSOFIA, LETRAS E CIÊNCIAS HUMANAS, 2011)

em virtude da escassez QUASE completa de publicações sobre o tema. (FACULDADE DE MEDICINA VETERINÁRIA E ZOOTECNIA, 2011)

QUASE todas as recaídas. (FACULDADE DE MEDICINA, 2011)

a partir dos perfis de velocidade QUASE-sinóticos durante a amostragem (INSITUTO INSTITUTO OCEANOGRÁFICO, 2011)

O estudo sobre a natureza da relação entre as práticas recomendadas de gestão de TI e seus resultados partiu da análise de 37 modelos de governança, sendo 15 específicos de GTI, dos quais três modelos foram escolhidos - CObIT vs.4.1, e SCM-CL vs.1.1 e ITIL vs.3 - por representarem QUASE que a totalidade de processos e ações práticas de todos os outros modelos relacionados à GTI. (FACULDADE DE ECONOMIA, ADMINISTRAÇÃO E CONTABILIDADE, 2011)

QUASE sempre vindas do mercado norte-americano (FACULDADE DE ECONOMIA, ADMINISTRAÇÃO E CONTABILIDADE, 2011)

QUASE 2000 espécies. (FACULDADE DE FILOSOFIA, LETRAS E CIÊNCIAS HUMANAS DE RIBEIRÃO PRETO, 2011)

Trata-se de um estudo descritivo de intervenção QUASE experimental (ESCOLA DE ENFERMAGEM, 2011)

QUASE circulares (INSTITUTO DE ASTRONOMIA, GEOFÍSICA E CIÊNCIAS ATMOSFÉRICAS, 2011)

QUASE inexplorada (FACULDADE DE FILOSOFIA, LETRAS E CIÊNCIAS HUMANAS, 2011)

mostrar um comportamento QUASE exclusivo dos machos. (INSTITUTO DE PSICOLOGIA, 2011)

QUASE todas as células transplantadas. (FACULDADE DE MEDICINA, 2011)

Atualmente no Brasil a carne ovina é comercializada QUASE exclusivamente congelada (FACULDADE DE MEDICINA VETERINÁRIA E ZOOTECNIA, 2011)

QUASE todas as atividades (FACULDADE DE CIÊNCIAS FARMACÊUTICAS DE RIBEIRÃO PRETO, 2011)

como fonte de carboidratos e de subsistência para QUASE um bilhão de pessoas (FACULDADE DE MEDICINA VETERINÁRIA E ZOOTECNIA, 2011)

o grau variou de QUASE perfeito a perfeito. (FACULDADE DE ODONTOLOGIA, 2011)

caracterizada pela hipomielinização do sistema nervoso central e afetando QUASE que exclusivamente indivíduos do sexo masculino. (INSTITUTO DE BIOCIÊNCIAS, 2011) 
QUASE 50\% da população (...) QUASE $80 \%$ da população (FACULDADE DE MEDICINA, 2011)

reduzir para QUASE zero (INSTITUTO DE BIOMÉDICAS, 2011)

QUASE 70\% na hidrólise (INSTITUTO DE BIOMÉDICAS, 2011)

QUASE experimental (ESCOLA DE ENFERMAGEM, 2011)

que transporta QUASE a metade do gás natural (FACULDADE DE FILOSOFIA, LETRAS E CIÊNCIAS HUMANAS, 2011)

estado QUASE estacionário (INSTITUTO DE QUÍMICA, 2011)

De qualquer maneira, todas elas são acessíveis QUASE que exclusivamente por meio do ensino privado. (FACULDADE DE FILOSOFIA, LETRAS E CIENCIAS HUMANAS, 2011)

identidade QUASE perdida (FACULDADE DE EDUCAÇÃO, 2011)

convergem QUASE certamente (INSTITUTO DE MATEMÁTICA E ESTATÍSTICA, 2011)

Para o segmento de mercado cortes de frango, as características de carcaça foram QUASE tão importantes quanto às de desempenho. (FACULDADE DE MEDICINA VETERINÁRIA E ZOOTECNIA, 2011)

Os resultados principais indicaram que, quando se trabalha com um modelo FL, as carteiras eficientes são compostas QUASE que exclusivamente por títulos indexados à inflação. (FACULDADE DE ECONOMIA, ADMINISTRAÇÃO E CONTABILIDADE, 2011)

QUASE linear (...) QUASE linear (INSTITUTO DE ASTRONOMIA, GEOFÍSICA E CIÊNCIAS ATMOSFÉRICAS, 2011)

contribuíram QUASE equitativamente (INSTITUTO DE QUÍMICA, 2011)

Os dados evidenciam que QUASE a totalidade dos(as) jovens consideram objetivos políticos sem importância para as suas vidas. (FACULDADE DE EDUCAÇÃO, 2011)

há QUASE três décadas (ESCOLA POLITÉCNICA, 2011)

em QUASE todo o território nacional (ENERGIA NUCLEAR NA AGRICULTURA, 2011)

QUASE religioso (FACULDADE DE DIREITO, 2011)

nesse espaço de QUASE três séculos (FACULDADE DE FILOSOFIA, LETRAS E CIÊNCIAS HUMANAS, 2011)

onde aranhas com abdomem esférico (fiandeiras QUASE ventrais) INSTITUTO DE BIOCIÊNCIAS, 2011)

QUASE todos os componentes (FACULDADE DE MEDICINA, 2011) 
e espécimes QUASE completos (...) até QUASE o topo do Grupo Corumbá (INSTITUTO DE GEOCIÊNCIAS, 2011)

O sequenciamento do genoma QUASE completo desses dez isolados primários revelou que três isolados primários pertencem ao grupo da CRF28_BF, três ao grupo da CRF29_BF e quatro foram classificados como formas recombinantes únicas (URFs). (INSTITUTO DE BIOMÉDICAS, 2011)

QUASE experimental (ESCOLA DE ENFERMAGEM, 2011)

QUASE completamente empírica (ESCOLA DE ENGENHARIA DE SÃO CARLOS, 2011)

Fato que faz com que São Bernardo deva sua modernidade exatamente à pluralidade discursiva, à indução da expectativa de valores literários, chegando QUASE a parecernos polifônico no sentido que Bakhtin estuda e propõe que seja a obra de Dostoiévski. (FACULDADE DE FILOSOFIA, LETRAS E CIÊNCIAS HUMANAS, 2011)

há QUASE 70 anos (FACULDADE DE CIÊNCIAS FARMACÊUTICAS DE RIBEIRÃO PRETO, 2011)

Por serem menores em tamanho, tais formigas utilizaram a secreção dos nectários QUASE que individualmente. (INSTITUTO DE BIOCIÊNCIAS, 2011)

Tal olhar filosófico manteve-se QUASE que absolutamente à parte das justificativas exploratórias imperialistas, tão atraentes às mentes inglesas e francesas, os orientalistas de Said, e tão exploradas pelos ditames literários e orientalistas apresentados por ele. (FACULDADE DE FILOSOFIA, LETRAS E CIÊNCIAS HUMANAS, 2011)

a incidência de QUASE todas, à exceção das neoplasias cutâneas (FACULDADE DE MEDICINA VETERINÁRIA E ZOOTECNIA, 2011)

A expansão das vagas no ensino fundamental, a democratização e QUASE universalização do acesso (FACULDADE DE EDUCAÇÃO, 2011)

O efeito tóxico apresentado pela BatroxLAAO foi QUASE completamente abolido pela adição de catalase, (FACULDADE DE CIÊNCIAS FARMACÊUTICAS DE RIBEIRÃO PRETO, 2011)

a QUASE totalidade das centrais (ESCOLA POLITÉCNICA, 2011)

O QUASE-experimento piloto (...) O segundo QUASE-experimento (...) Em ambos os QUASE-experimentos (FACULDADE DE ECONOMIA, ADMINISTRAÇÃO E CONTABILIDADE, 2011)

Posteriormente, nossa análise volta-se a compreensão dessa relação entre o Estado e os sindicatos quando da formação de um Estado Corporativo no Brasil, com o predomínio de uma legislação sindical mais limitante, obrigando essas entidades a realizarem uma ação territorial menos plural, restrita QUASE que, exclusivamente, à área municipal. (FACULDADE DE FILOSOFIA, LETRAS E CIÊNCIAS HUMANAS, 2011)

As adolescentes QUASE na sua totalidade (FACULDADE DE SAÚDE PÚBLICA, 2011) 
QUASE lineares (INSTITUTO DE MATEMÁTICA E ESTATÍSTICA, 2011)

Para testar esta hipótese realizamos um QUASE experimento com dois grupos nãoequivalentes. (FACULDADE DE FILOSOFIA, LETRAS E CIÊNCIAS HUMANAS, 2011)

decorridos QUASE 20 anos (FACULDADE DE SAÚDE PÚBLICA, 2011)

durante a trajetória de resfriamento QUASE isobárico (INSTITUTO DE GEOCIÊNCIAS, 2011)

QUASE todos os ecossistemas (...) QUASE dois terços do total de espécies coletadas. (FACULDADE DE FILOSOFIA, LETRAS E CIÊNCIAS HUMANAS DE RIBEIRÃO PRETO, 2011)

(aumento da frequência em QUASE 20\%) (INSTITUTO DE QUÍMICA, 2011)

a QUASE 15 vezes (FACULDADE DE SAÚDE PÚBLICA, 2011)

o problema torna-se QUASE-estático. (ESCOLA POLITÉCNICA, 2011)

de QUASE todas as cepa (FACULDADE DE MEDICINA VETERINÁRIA E ZOOTECNIA, 2011)

A QUASE totalidade dos lactentes (FACULDADE DE ODONTOLOGIA, 2011)

QUASE 70\% de todo o volume de combustível (FACULDADE DE ECONOMIA, ADMINISTRAÇÃO E CONTABILIDADE, 2011)

QUASE um- terço deste total (FACULDADE DE MEDICINA, 2011)

Esse material, constituído QUASE que somente por terra obtida no local da obra, tem todas as propriedades do que se chama uma construção sustentável, incluindo um mínimo de consumo de energia se comparado a estruturas convencionais em aço e concreto. (ESCOLA POLITÉCNICA, 2011)

nos textos em alemão o autor QUASE não aparece, (FACULDADE DE FILOSOFIA, LETRAS E CIÊNCIAS HUMANAS, 2011)

O seu [o da sociedade portuguesa] ingresso tardio no coro europeu apenas a partir dos grandes descobrimentos marítimos determinou um tipo de sociedade que se desenvolveu, em alguns sentidos, QUASE à margem das outras nações europeias e constitui-se uma zona de transição por ser uma das pontes pelas quais a Europa comunica-se com outros mundos. (FACULDADE DE FILOSOFIA, LETRAS E CIÊNCIAS HUMANAS, 2011)

mostrou que para o grupo A houve diferença estatisticamente significativa em QUASE todos os períodos com exceção do período basal (...) e para o grupo B tivemos diferenças estatisticamente significativa para QUASE todos os períodos com exceção dos períodos basal para o tratamento $(\mathrm{p}=0,808)$, (...) em QUASE todos os períodos com exceção do período basal para o período de tratamento, e para o grupo B estatisticamente significativa em QUASE todos os períodos com exceção do período basal para o tratamento $(\mathrm{p}=0,617)$ (ESCOLA DE ENFERMAGEM, 2011) 
Estudos de consumo de oxigênio mostraram que MAA é, como esperado, QUASE uma ordem de grandeza mais reativo que AA. (INSTITUTO DE QUÍMICA, 2011)

comprovou-se que após o resfriamento lento, o sinal era restituído a QUASE o mesmo valor que antes (INSTITUTO DE FÍSICA, 2011)

em QUASE todos os casos, (FACULDADE DE ARQUITETURA E URBANISMO, 2011)

convergiram para uma associação QUASE nula (INSTITUTO DE PSICOLOGIA, 2011)

Escrito QUASE meio século depois (FACULDADE DE FILOSOFIA, LETRAS E CIÊNCIAS HUMANAS, 2011)

difere QUASE totalmente das encontradas nas outras duas fontes. (FACULDADE DE FILOSOFIA, LETRAS E CIÊNCIAS HUMANAS, 2011)

A partir do ensaio QUASE-estático (ESCOLA POLITÉCNICA, 2011)

resultado QUASE similar (ESCOLA SUPERIOR DE AGRICULTURA "LUIZ DE QUEIROZ”, 2011)

QUASE uma década depois, (FACULDADE DE DIREITO, 2011)

uma superfície QUASE homogênea (INSTITUTO DE QUÍMICA, 2011)

a ingestão de vitamina $\mathrm{K}$ foi insuficiente em QUASE metade da amostra (INSTITUTO DE QUÍMICA, 2011)

entre QUASE todos os parâmetros estudados (FACULDADE DE MEDICINA, 2011)

com quatro grupos sociais de Santo André - grupo central, QUASE central, QUASE periférico e periférico (ESCOLA DE ENFERMAGEM, 2011)

está QUASE totalmente (INSTITUTO DE ASTRONOMIA, GEOFÍSICA E CIÊNCIAS ATMOSFÉRICAS, 2011)

em QUASE todas as localidades (INSTITUTO DE BIOCIÊNCIAS, 2011)

QUASE sempre irreversíveis (ESCOLA SUPERIOR DE AGRICULTURA “LUIZ DE QUEIROZ”, 2011)

Isso se faz aqui através da leitura da obra de Dan Flavin, artista americano que utilizou a lâmpada fluorescente como material QUASE que exclusivo em seus trabalhos. (FACULDADE DE ARQUITETURA E URBANISMO, 2011)

e QUASE nenhuma influência da temperatura do ninho. (FACULDADE DE FILOSOFIA, LETRAS E CIÊNCIAS HUMANAS DE RIBEIRÃO PRETO, 2011)

indicando paralelismo QUASE absoluto (FACULDADE DE ODONTOLOGIA, 2011)

receptor por QUASE todos os FGFs (INSTITUTO DE BIOCIÊNCIAS, 2011) 
é QUASE sempre um pretexto (FACULDADE DE EDUCAÇÃO, 2010)

escritas há QUASE seiscentos anos (FACULDADE DE EDUCAÇÃO, 2010)

recuperaram QUASE totalmente, (ESCOLA SUPERIOR DE AGRICULTURA "LUIZ DE QUEIROZ”, 2010)

QUASE-experimental(ESCOLA DE ENFERMAGEM, 2010)

voltadas QUASE exclusivamente para a pesquisa. (FACULDADE DE ECONOMIA, ADMINISTRAÇÃO E CONTABILIDADE, 2010)

em QUASE todas as estruturas (INSTITUTO DE BIOCIÊNCIAS, 2010)

superou de 3 até QUASE 40 vezes (INSTITUTO ENERGIAS NUCLEARES, 2010)

retirada de QUASE toda sua vegetação (ENERGIA NUCLEAR PARA AGRICULTURA, 2010)

Al-Farabi escreveu a Cidade excelente já na maturidade, construindo-a QUASE de modo aforístico (FACULDADE DE FILOSOFIA, LETRAS E CIÊNCIAS HUMANAS, 2010)

QUASE todas as gestantes (93,58 por cento) (FACULDADE DE SAÚDE PÚBLICA, 2010)

Devido ao fato da correnteza ser QUASE permanente (ESCOLA POLITÉCNICA, 2010)

comunicação da ciência nestes QUASE 350 anos (FACULDADE DE FILOSOFIA, LETRAS E CIÊNCIAS HUMANAS, 2010)

uma arma de destruição em massa de alcance QUASE inimaginável (FACULDADE DE FILOSOFIA, LETRAS E CIÊNCIAS HUMANAS, 2010)

alquilados predominaram em QUASE todas as amostras, (INSTITUTO OCEANOGRÁFICO, 2010)

cobre QUASE a totalidade da área (INSTITUTO DE GEOCIÊNCIAS, 2010)

por QUASE 100 anos (FACULDADE DE MEDICINA, 2010)

uma dependência QUASE linear (INSTITUTO DE FÍSICA, 2010)

QUASE sempre (ESCOLA POLITÉCNICA, 2010)

Existem QUASE 20.000 espécies de abelhas descritas no mundo. No Brasil são conhecidas QUASE 400 espécies (ESCOLA POLITÉCNICA, 2010)

Como resultado principal obteve-se que a maioria dos casos observados foi de linhas que não se propagaram, permanecendo QUASE estacionárias nas proximidades da costa norte do Brasil. (INSTITUTO DE ASTRONOMIA, GEOFÍSICA E CIÊNCIAS ATMOSFÉRICAS, 2010) 
Expõe o conceito de função administrativa judicante (QUASE jurisdicional) (FACULDADE DE DIREITO, 2010)

Existem QUASE duas vezes mais carbono (FACULDADE DE FILOSOFIA, LETRAS E CIÊNCIAS HUMANAS DE RIBEIRÃO PRETO, 2010)

segundo Bakhtin, é QUASE uma enciclopédia dos principais temas da obra do escritor russo. (FACULDADE DE FILOSOFIA, LETRAS E CIÊNCIAS HUMANAS, 2010)

QUASE todos (96,3\%) (FACULDADE DE MEDICINA, 2010)

removeram QUASE 100\% (INSTITUTO DE QUÍMICA, 2010)

em QUASE todas as sub-bacias (INSTITUTO DE BIOCIÊNCIAS, 2010)

o equilíbrio em QUASE todas as condições sensoriais (FACULDADE DE MEDICINA, 2010)

são fatos QUASE contemporâneos. (FACULDADE DE FILOSOFIA, LETRAS E CIÊNCIAS HUMANAS, 2010)

em QUASE todas as medidas. (FACULDADE DE MEDICINA, 2010)

foi QUASE 4 vezes maior do que no coração nativo (FACULDADE DE MEDICINA, 2010)

as órbitas do campo original são QUASE-periódicas (INSTITUTO DE MATEMÁTICA E ESTATÍSTICA, 2010)

QUASE esféricas (FACULDADE DE CIÊNCIAS FARMACÊUTICAS DE RIBEIRÃO PRETO, 2010)

com QUASE nenhuma histerese (INSTITUTO DE QÚMICA, 2010)

Nesse tema, o trabalho mostra os resultados positivos conseguidos nas áreas de produtos em geral e, particularmente, nos produtos elétricos, cuja QUASE totalidade é objeto de certificação compulsória pelo Inmetro. (INSTITUTO DE ELETROTÉCNICA E ENERGIA, 2010)

QUASE a totalidade das crianças atendidas (95\%) (FACULDADE DE SAÚDE PÚBLICA, 2010)

o período de QUASE duzentos (de 1722 até 1919) (FACULDADE DE FILOSOFIA, LETRAS E CIÊNCIAS HUMANAS, 2010)

é preciso delinear melhor o leitor-padrão, ou modelo, dessas publicações. Além disso, constata-se a concentração de temas (com QUASE ausência da tradução do noticiário adulto para as crianças (ESCOLA DE COMUNICAÇÃO E ARTES, 2010)

Em QUASE todos os países da África Central e Ocidental. (INSTITUTO DE ELETROTÉCNICA E ENERGIA, 2010)

em QUASE todos estes encontros. (ESCOLA DE ENFERMAGEM, 2010) 
trabalhos com temas políticos foi QUASE nula (FACULDADE DE FILOSOFIA, LETRAS E CIÊNCIAS HUMANAS, 2010)

Atualmente o estudo do comportamento termodinâmico destas moléculas tem ficado restrito QUASE que exclusivamente a abordagem via ensemble canônico. (INSTITUTO DE FÍSICA, 2010)

QUASE todos os clados (INSTITUTO DE BIOCIÊNCIAS, 2010)

QUASE sempre (...) QUASE sempre (ESCOLA POLITÉCNICA, 2010)

retratar QUASE a totalidade (mais de $98 \%$ no ano de 2003) (FACULDADE DE ECONOMIA, ADMINISTRAÇÃO E CONTABILIDADE, 2010)

são QUASE inexistentes (FACULDADE DE FILOSOFIA, LETRAS E CIÊNCIAS HUMANAS, 2010)

sendo QUASE 60\% a mais em relação a 2008, (...) QUASE a totalidade das chuvas (FACULDADE DE FILOSOFIA, LETRAS E CIÊNCIAS HUMANAS DE RIBEIRÃO PRETOS, 2010)

Ensaios de oxidação do tipo QUASE-isotérmica (INSTITUTO DE FÍSICA, 2010)

que antes se localizavam QUASE exclusivamente no Centro da cidade (FACULDADE DE ARQUITETURA E URBANISMO, 2010)

um Estado frágil e QUASE inexistente (FACULDADE DE FILOSOFIA, LETRAS E CIÊNCIAS HUMANAS, 2010)

um valor de concordância QUASE perfeita. (FACULDADE DE FILOSOFIA, LETRAS E CIÊNCIAS HUMANAS, 2010)

de diferentes regiões do município de Santo André, SP, Brasil - central, QUASEcentral, QUASE-periférica e periférica. (ESCOLA DE ENFERMAGEM, 2010)

tornam tal desafio QUASE impossível. (FACULDADE DE EDUCAÇÃO, 2010)

QUASE a totalidade das causas. (...) em QUASE todos os grupos etários (FACULDADE DE SAÚDE PÚBLICA, 2010)

Após QUASE vinte anos de sua criação (FACULDADE DE FILOSOFIA, LETRAS E CIÊNCIAS HUMANAS, 2010)

de forma QUASE adiabática (ASTROINSTITUTO DE FÍSICA, 2010)

as séries de dados com bases em funcionais senoidais QUASE- ortogonais, (GEOINSTITUTO DE FÍSICA, 2010)

Recentemente surgiu um novo PKC baseado em QUASE-grupos multivariados quadráticos (ESCOLA POLITÉCNICA, 2010)

obtiveram de forma geral valores substanciais ou QUASE perfeitos. (ESCOLA DE ENFERMAGEM, 2010) 
QUASE todos os estímulos (FACULDADE DE MEDICINA, 2010)

Em QUASE todos os ambientes (ESCOLA SUPERIOR DE AGRICULTURA "LUIZ DE QUEIROZ”, 2010)

durante QUASE meio século (FACULDADE DE FILOSOFIA, LETRAS E CIÊNCIAS HUMANAS, 2010)

ocupando QUASE a totalidade dos espaços (FACULDADE DE ODONTOLOGIA, 2010)

QUASE todos os genes (INSTITUTO DE QUÍMICA, 2010)

Artistas QUASE arquitetos. Arquitetos QUASE artistas. (...) atuando QUASE Como Arquitetos. (FACULDADE DE ARQUITETURA E URBANISMO, 2010)

em QUASE todos os ensaios (INSTITUTO DE QUÍMICA, 2010)

QUASE sempre (BIOCIÊNCIA, 2010)

as QUASE-florestas de São Luiz do Paraitinga (SP). (INSTITUTO DE BIOCIÊNCIAS, 2010)

classe de códigos de Goppa QUASE-diádicos (ESCOLA POLITÉCNICA, 2010)

Nesses locais luminosos onde a imagem se oculta, QUASE desaparece e às vezes se ausenta (ESCOLA DE COMUNICAÇÃO E ARTES, 2010)

a escola QUASE não fala sobre o assunto. (ESCOLA DE ENFERMAGEM, 2010)

o que se refere ao delineamento dos estudos, observou-se que 19 (91,0\%) eram QUASE-experimentais e, $02(9,0 \%)$ observacionais. (ESCOLA DE ENFERMAGEM, 2010)

Estes dois LI's tem QUASE a mesma densidade (INSTITUTO DE QUÍMICA, 2010)

QUASE três milhões de toneladas (ENERGIA NUCLEAR NA AGRICULTURA, 2010)

ao QUASE-delito romano ${ }^{164}$ (FACULDADE DE DIREITO, 2010)

por conta da limitação QUASE total, (FACULDADE DE ECONOMIA, ADMINISTRAÇÃO E CONTABILIDADE, 2010)

QUASE completa mineralização (ESCOLA POLITÉCNICA, 2010)

em QUASE todo o mundo, (FACULDADE DE EDUCAÇÃO, 2010)

foi QUASE perfeita, (FACULDADE DE MEDICINA, 2010)

em QUASE todas as áreas florestais (FACULDADE DE MEDICINA VETERINÁRIA E ZOOTECNIA, 2010)

${ }^{164}$ Foram quatro ocorrências deste dado neste resumo. 
QUASE sempre $^{165}$ (FACULDADE DE FILOSOFIA, LETRAS E CIÊNCIAS HUMANAS, 2010)

QUASE todos os domínios (ESCOLA DE ENFERMAGEM, 2010)

de QUASE todos os brasileiros (FACULDADE DE DIREITO, 2010)

QUASE instantânea (ESCOLA POLITÉCNICA, 2010)

QUASE 90 por cento (FACULDADE DE SAÚDE PÚBLICA, 2010)

QUASE inexistente (FACULDADE DE FILOSOFIA, LETRAS E CIÊNCIAS HUMANAS, 2010)

o que torna as capturas e os estudos comportamentais QUASE impossíveis (ESCOLA SUPERIOR DE AGRICULTURA “LUIZ DE QUEIROZ”, 2010)

QUASE 90\%, (INSTITUTO DE QUÍMICA, 2010)

foi QUASE duas vezes maior (FACULDADE DE SAÚDE PÚBLICA, 2010)

QUASE dois séculos e meio (FACULDADE DE EDUCAÇÃO, 2010)

mas QUASE nada falou sobre as populações africanas, (FACULDADE DE FILOSOFIA, LETRAS E CIÊNCIAS HUMANAS, 2010)

o que pode apontar para o Pato de que a escala deveria ser utilizada sem subdivisões ou a exclusão de itens. Na avaliação da validade concorrente foi obtida uma força de concordância também QUASE perfeita. (FACULDADE DE MEDICINA, 2010)

QUASE 20\% (INSTITUTO DE QUÍMICA, 2010)

QUASE não abordado nas obras nacionais (FACULDADE DE DIREITO, 2010)

uma voz QUASE silenciosa e marcada (FACULDADE DE FILOSOFIA, LETRAS E CIÊNCIAS HUMANAS, 2010)

QUASE sinótico ${ }^{166}$ (INSTITUTO OCEANOGRÁFICO, 2010)

QUASE não há afastamentos (FACULDADE DE SAÚDE PÚBLICA, 2010)

QUASE todas as proteínas (FACULDADE DE FILOSOFIA, LETRAS E CIÊNCIAS HUMANAS DE RIBEIRÃO PRETO, 2010)

A estabilidade do Orçamento Autorizativo no Brasil é analisado em seguida e pode ser visto como um caso complementar aos demais, pois trata de uma QUASE mudança institucional. (FACULDADE DE FILOSOFIA, LETRAS E CIÊNCIAS HUMANAS, 2010)

em QUASE toda a extensão (INSTITUTO DE ASTRONOMIA, GEOFÍSICA E CIÊNCIAS ATMOSFÉRICAS, 2010)

\footnotetext{
${ }^{165}$ Foram duas ocorrências deste dado neste resumo.

${ }^{166}$ Foram duas ocorrências deste dado neste resumo.
} 
QUASE 40\% (FACULDADE DE ECONOMIA, ADMINISTRAÇÃO E CONTABILIDADE, 2010)

QUASE em sua totalidade, (FACULDADE DE EDUCAÇÃO, 2010)

foram caracterizadas pela QUASE ausência de DARPP-32 (INSTITUTO DE BIOMÉDICAS, 2010)

QUASE a metade da floresta (INSTITUTO DE BIOCIÊNCIAS, 2010)

em QUASE todos os romances africanos (FACULDADE DE FILOSOFIA, LETRAS E CIÊNCIAS HUMANAS, 2010)

tiveram sua composição centesimal QUASE inalterada (ESCOLA SUPERIOR DE AGRICULTURA “LUIZ DE QUEIROZ”, 2010)

foi QUASE nula (ESCOLA POLITÉCNICA, 2010)

QUASE todos os gêneros (INSTITUTO DE BIOCIÊNCIAS, 2010)

QUASE a totalidade dos pesquisadores (...) aceitação QUASE universal dos resultados (MUSEU DE ARQUEOLOGIA E ETNOLOGIA, 2010)

No entanto, para dispositivos com Wfin menores que $0,7 \mu \mathrm{m}$ os métodos $\mathrm{Y}$-function e McLarty apresentaram os piores resultados chegando a QUASE 50\% de erro para o dispositivo mais estreito (Wfin $=50 \mathrm{~nm})$. (ESCOLA POLITÉCNICA, 2010)

em QUASE todas as residências, (INSTITUTO DE ELETROTÉCNICA E ENERGIA, 2010)

ao ponto de se recategorizar como verbo QUASE-auxiliar, (FACULDADE DE FILOSOFIA, LETRAS E CIÊNCIAS HUMANAS, 2010)

QUASE 40\% do volume hipocampal (FACULDADE DE MEDICINA, 2010)

QUASE metade dos entrevistados (47,6\%) (FACULDADE DE MEDICINA, 2010)

QUASE sempre (FACULDADE DE FILOSOFIA, LETRAS E CIÊNCIAS HUMANAS DE RIBEIRÃO PRETO, 2010)

QUASE 20\% (ESCOLA DE ENFERMAGEM, 2010)

sendo QUASE zero nas demais freqüências. (INSTITUTO DE PSICOLOGIA, 2010)

o governo realiza campanhas QUASE-periódicas de vacinação. (ESCOLA POLITÉCNICA, 2010)

experiências de QUASE-morte (INSTITUTO DE PSICOLOGIA, 2010)

com QUASE 100\% de conformidade (ESCOLA DE ENFERMAGEM, 2010)

abordagem QUASE-experimental, (ESCOLA DE ENFERMAGEM, 2010)

a QUASE totalidade da variação (INSTITUTO DE QUÍMICA, 2010) 
estão QUASE totalmente satisfeitos (...) em QUASE todas as dimensões (FACULDADE DE ECONOMIA, ADMINISTRAÇÃO E CONTABILIDADE, 2010)

Contudo, a linha que separava os dois grupos não era facilmente identificável. As gentes de Maganja da Costa (Zambézia) foram um exemplo de como se podia pertencer aos dois grupos QUASE que simultaneamente (FACULDADE DE FILOSOFIA, LETRAS E CIÊNCIAS HUMANAS, 2010)

Supõe-se que o movimento diafragmático é o movimento principal e todas as estruturas do pulmão se movem QUASE que totalmente sincronicamente. (ESCOLA POLITÉCNICA, 2010)

GE1 = pobre - moderada; GE2 = moderada 12013 substancial, e GE3 $=$ QUASE perfeita ${ }^{167}$. (FACULDADE DE MEDICINA, 2010)

em QUASE todas as categorias (ESCOLA DE ENFERMAGEM, 2010)

conjunto QUASE completo (INSTITUTO DE BIOCIÊNCIAS, 2010)

pelo período de QUASE dois anos (INSTITUTO DE PSICOLOGIA, 2010)

comunicação da ciência nestes QUASE 350 anos (FACULDADE DE FILOSOFIA, LETRAS E CIÊNCIAS HUMANAS, 2010)

por QUASE 100 anos (FACULDADE DE MEDICINA, 2010)

Após QUASE vinte anos de sua criação (FACULDADE DE FILOSOFIA, LETRAS E CIÊNCIAS HUMANAS, 2010)

QUASE sempre (ESCOLA SUPERIOR DE AGRICULTURA “LUIZ DE QUEIROZ”, 2010)

o QUASE-método, utilizado (ESCOLA DE COMUNICAÇÃO E ARTES, 2010)

QUASE 11 milhões (FACULDADE DE SAÚDE PÚBLICA, 2010)

e QUASE eliminar do horizonte a possibilidade (FACULDADE DE ARQUITETURA E URBANISMO, 2010)

QUASE todos os estudos (INSTITUTO DE BIOMÉDICAS, 2010)

e QUASE todas ocorrem (...) e QUASE todas estão (INSTITUTO DE BIOCIÊNCIAS, 2010)

a pressão QUASE atmosférica (ESCOLA DE ENGENHARIA DE SÃO CARLOS, 2010)

QUASE sempre (ESCOLA POLITÉCNICA, 2010)

seus QUASE-irmãos (INSTITUTO DE PSICOLOGIA, 2010)

QUASE não foram observados (FACULDADE DE MEDICINA VETERINÁRIA E ZOOTECNIA, 2010)

${ }^{167}$ Foram três ocorrências deste dado neste resumo. 
QUASE experimental (ESCOLA DE ENFERMAGEM, 2010)

aspectos avaliados foi considerado QUASE perfeito (83\%) e o de concordância interjuízas variou de regular (35\%) a QUASE perfeito (100\%). (FACULDADE DE ODONTOLOGIA, 2009)

QUASE totalidade dos professores (FACULDADE DE EDUCAÇÃO, 2009)

em QUASE todos (FACULDADE DE MEDICINA, 2009)

QUASE 50\% dos entrevistados (ESCOLA DE ENFERMAGEM, 2009)

Enquanto os corpos-de-prova de referência ao final dos 45 dias de ensaio de carbonatação acelerada foram QUASE que totalmente carbonatados (ESCOLA POLITÉÇNICA, 2009)

QUASE sempre (FACULDADE DE MEDICINA, 2009)

demonstrando-se o papel QUASE solitário do epitélio central (FACULDADE DE FILOSOFIA, LETRAS E CIÊNCIAS HUMANAS DE RIBEIRÃO PRETOS, 2009)

num discurso QUASE uníssono (INSTITUTO DE PSICOLOGIA, 2009)

ara investigar se estas ondas são instáveis, aplicou-se um modelo linear QUASEgeostrófico (INSTIUTO OCENOGRÁFICO, 2009)

são capazes de explicar QUASE a totalidade dos prêmios (FACULDADE DE ECONOMIA, ADMINISTRAÇÃO E CONTABILIDADE, 2009)

QUASE sempre (ESCOLA SUPERIOR DE AGRICULTURA “LUIZ DE QUEIROZ”, 2009)

Aplicando-se a técnica de EPG, verificou-se que as folhas novas favorecem a alimentação floemática de D. citri; QUASE que a totalidade dos indivíduos avaliados sobre folhas novas assintomáticas encontraram o floema e permaneceram por mais tempo neste tecido. (ESCOLA SUPERIOR DE AGRICULTURA "LUIZ DE QUEIROZ”, 2009)

QUASE todos os pigmentos (INSTITUTO DE QUÍMICA, 2009)

Até o momento a inclusão desse grupo tem ficado sob responsabilidade QUASE que exclusiva do docente. (FACULDADE DE MEDICINA, 2009)

QUASE metade deles (ESCOLA DE ENFERMAGEM, 2009)

QUASE cinquenta anos (FACULDADE DE FILOSOFIA, LETRAS E CIÊNCIAS HUMANAS, 2009)

entre QUASE todas as linhagens isoladas (FACULDADE DE CIÊNCIAS FARMACÊUTICAS DE RIBEIRÃO PRETO, 2009)

QUASE 600 mil ha, (ESCOLA SUPERIOR DE AGRICULTURA "LUIZ DE QUEIROZ”, 2009) 
Em suas propostas, sua autobiografia está sempre presente, QUASE como uma "terapia", (FACULDADE DE FILOSOFIA, LETRAS E CIÊNCIAS HUMANAS, 2009)

de forma QUASE direta (FACULDADE DE FILOSOFIA, LETRAS E CIÊNCIAS HUMANAS, 2009)

um cotidiano QUASE inteiramente heterossexual. (FACULDADE DE EDUCAÇÃO, 2009)

à QUASE metade desse valor (ESCOLA SUPERIOR DE AGRICULTURA “LUIZ DE QUEIROZ”, 2009)

em tempo QUASE real (INSTITUTO DE QUÍMICA, 2009)

A QUASE totalidade dos recém-nascidos (ESCOLA DE ENFERMAGEM, 2009)

(QUASE a totalidade do Estado) (ESCOLA SUPERIOR DE AGRICULTURA "LUIZ DE QUEIROZ”, 2009)

em QUASE todos（FACULDADE DE EDUCAÇÃO, 2009)

Um inicial, com pouco uso e QUASE sem notícias de casos. (FACULDADE DE MEDICINA, 2009)

QUASE a totalidade dos casos (FACULDADE DE MEDICINA VETERINÁRIA E ZOOTECNIA, 2009)

um campo QUASE inexplorado (...) Entretanto, a cooperação se deu entre autores do mesmo país e instituição, QUASE não havendo estudos com colaboração internacional. (ESCOLA DE COMUNICAÇÃO E ARTES, 2009)

houve duas relações de QUASE dependência (FACULDADE DE MEDICINA VETERINÁRIA E ZOOTECNIA, 2009)

e a unicidade QUASE certa (INSTITUTO DE MATEMÁTICA E ESTATÍSTICA, 2009)

propósitos da educação voltados, QUASE exclusivamente, à capacitação dos alunos (FACULDADE DE EDUCAÇÃO, 2009)

mantiveram-se QUASE intactos (FACULDADE DE FILOSOFIA, LETRAS E CIÊNCIAS HUMANAS, 2009)

QUASE todas as classes (FACULDADE DE SAÚDE PÚBLICA, 2009)

Estes canais são QUASE que exclusivamente expressos no sistema nervoso central (FACULDADE DE MEDICINA, 2009)

não ocorre a redução das espécies formadas pela oxidação reversível ou QUASE reversível do antioxidante. (...) mostrando valores máximos com QUASE uma ordem de grandeza superior ao apresentado pelo composto (INSTITUTO DE QUÍMICA, 2009) 
o aspecto mais complexo e QUASE inabordável da psicologia do inconsciente. (INSTITUTO DE PSICOLOGIA, 2009)

A maioria deles se origina dos nervos simpáticos, localizando-se QUASE que exclusivamente no mediastino posterior. (FACULDADE DE MEDICINA, 2009)

Esta representação, conhecida como QUASE Linear a Parâmetros Variantes (QUASELPV) (ESCOLA DE ENGENHARIA DE SÃO CARLOS, 2009)

O valor recolhido anualmente permitiria QUASE dobrar os valores aplicados (FACULDADE DE ECONOMIA, ADMINISTRAÇÃO E CONTABILIDADE, 2009)

para QUASE todos os catalisadores (INSTITUTO DE QUÍMICA, 2009)

O grau de conversão e a contração de polimerização variaram na sequência: CQ < DEPT $<$ DMPT ' $<$ OU =' CEMA 'QUASE IGUAL ${ }^{168}$ A' DABE < DMAEMA. (FACULDADE DE ODONTOLOGIA, 2009)

parecem QUASE todos de acordo (FACULDADE DE FILOSOFIA, LETRAS E CIÊNCIAS HUMANAS, 2009)

em QUASE todo o mundo (INSTITUTO DE BIOMÉDICAS, 2009)

QUASE a totalidade das mães (99\%) (FACULDADE DE SAÚDE PÚBLICA, 2009)

O uso da cocaína na forma de crack vem crescendo nos últimos anos quando comparado às demais vias de administração. Contribuem para esse fato a obtenção QUASE imediata de efeitos e a maior facilidade de uso (FACULDADE DE SAÚDE PÚBLICA, 2009)

após QUASE um século (FACULDADE DE FILOSOFIA, LETRAS E CIÊNCIAS HUMANAS, 2009)

Plantas QUASE isogênicas (ESCOLA SUPERIOR DE AGRICULTURA "LUIZ DE QUEIROZ”, 2009)

o desconhecimento da realidade socioeconômica e cultural dos alunos e de seus sonhos tem criado descontentamentos entre alunos, que percorrem apaticamente (ou indisciplinadamente) o curso QUASE que, exclusivamente, para terminá-lo o quanto antes. (FACULDADE DE EDUCAÇÃO, 2009)

O órgão é QUASE totalmente envolto pelo pulmão (FACULDADE DE FILOSOFIA, LETRAS E CIÊNCIAS HUMANAS DE RIBEIRÃO PRETOS, 2009)

e QUASE sempre (ESCOLA DE ENGENHARIA DE SÃO CARLOS, 2009)

QUASE periódicas ${ }^{169}$ (ESCOLA POLITÉCNICA, 2009)

já é QUASE um consenso (...) em estágio QUASE embrionário (FACULDADE DE ECONOMIA, ADMINISTRAÇÃO E CONTABILIDADE, 2009)

\footnotetext{
${ }^{168}$ Foram seis ocorrências deste dado neste resumo.

${ }^{169}$ Foram duas ocorrências deste dado neste resumo.
} 
Esta experiência de QUASE inversão de papéis (FACULDADE DE FILOSOFIA, LETRAS E CIÊNCIAS HUMANAS, 2009)

chama atenção pela intensa concentração populacional e a QUASE extinção da cobertura vegetal (FACULDADE DE FILOSOFIA, LETRAS E CIÊNCIAS HUMANAS, 2009)

em regime QUASE-estático de forças (ESCOLA DE ENGENHARIA DE SÃO CARLOS, 2009)

A fase de QUASE-exaustão foi encontrada principalmente entre as mulheres (FACULDADE DE SAÚDE PÚBLICA, 2009)

por materiais frágeis, QUASE-frágeis e dúcteis. (ESCOLA DE ENGENHARIA DE SÃO CARLOS, 2009)

por derivarem de QUASE-experimentos, (ESCOLA DE ENFERMAGEM, 2009)

Para os dispositivos baseados em 'Alq IND. 3', OLEDs dopados e não dopados e um dispositivo e-only, foi observada somente MR negativa, enquanto que para um dispositivo h-only foi observado um novo efeito QUASE constante e positivo. (INSTITUTO DE FÍSICA, 2009)

QUASE todos os neurônios (FACULDADE DE FILOSOFIA, LETRAS E CIÊNCIAS HUMANAS DE RIBEIRÃO PRETOS, 2009)

QUASE 80\% (...) QUASE 70\% (INSTITUTO OCEANOGRÁFICO, 2009)

em QUASE toda a amostra (96\%) (...) em QUASE todos os indivíduos avaliados (FACULDADE DE FILOSOFIA, LETRAS E CIÊNCIAS HUMANAS DE RIBEIRÃO PRETOS, 2009)

em QUASE todas ${ }^{170}$ as faixas etárias (FACULDADE DE SAÚDE PÚBLICA, 2009)

QUASE quinze anos (FACULDADE DE FILOSOFIA, LETRAS E CIÊNCIAS HUMANAS, 2009)

distribuídos QUASE equitativamente (INSTITUTO DE QUÍMICA, 2009)

em QUASE todos os tumores (INSTITUTO DE QUÍMICA, 2009)

QUASE a metade dos pacientes (45,2\%) (FACULDADE DE MEDICINA, 2009)

há QUASE um século (FACULDADE DE FILOSOFIA, LETRAS E CIÊNCIAS HUMANAS, 2009)

estudo quantitativo do tipo QUASE-experimental (ESCOLA DE ENFERMAGEM, 2009)

atingiu QUASE completa densificação (ESCOLA POLITÉCNICA, 2009)

QUASE totalmente origina (ESCOLA DE COMUNICAÇÃO E ARTES, 2009)

${ }^{170}$ Foram duas ocorrências deste dado neste resumo. 
em QUASE toda a distribuição (INSTITUTO DE BIOCIÊNCIAS, 2009)

Embora os coeficientes de mortalidade pelos cânceres de mama e de colo do útero tenham se mantido QUASE estacionários em São Paulo (FACULDADE DE SAÚDE PÚBLICA, 2009)

em QUASE todas as populações (FACULDADE DE SAÚDE PÚBLICA, 2009)

a QUASE totalidade mulheres (INSTITUTO DE PSICOLOGIA, 2009)

em QUASE todas as estações (INSITUTO INSTITUTO OCEANOGRÁFICO, 2009)

de QUASE a totalidade da população brasileira, (FACULDADE DE ODONTOLOGIA, 2009)

analisada pela estatística Kappa, variou entre razoável $(0,32)$ a QUASE perfeita $(0,87)$

(HRAC - HOSPITAL REABILITAÇÃO DE ANOMALIAS CRANIOFACIAIS, 2009)

QUASE auto-suficiência (FACULDADE DE ECONOMIA, ADMINISTRAÇÃO E CONTABILIDADE, 2009)

QUASE três vezes mais (FACULDADE DE FILOSOFIA, LETRAS E CIÊNCIAS HUMANAS DE RIBEIRÃO PRETOS, 2009)

antes, QUASE impossível (FACULDADE DE FILOSOFIA, LETRAS E CIÊNCIAS HUMANAS, 2009)

de delineamento QUASE experimental, (ESCOLA DE ENFERMAGEM, 2009)

dados QUASE-sinóticos de velocidade (...) pela grade amostral QUASE-sinótica (...) a um modelo QUASE-geostrófico (INSTITUTO OCEANOGRÁFICO, 2009)

em QUASE todo o território nacional; (ESCOLA DE ENFERMAGEM, 2009)

em QUASE todos os períodos (ESCOLA DE ENGENHARIA DE SÃO CARLOS, 2009)

Pensa-se que o risco para os participantes é QUASE nulo, uma vez que a utilização de tais instrumentos não envolve danos físicos. (ESCOLA DE ENFERMAGEM, 2009)

macroestruturas compostas QUASE completamente de grãos colunares (ESCOLA POLITÉCNICA, 2009)

QUASE sempre (ESCOLA POLITÉCNICA, 2009)

No Brasil, a modelação de fluxo e transporte de solutos na zona não-saturada é voltada, QUASE que exclusivamente, aos problemas relacionados às atividades agrícolas. (ESCOLA DE ENGENHARIA DE SÃO CARLOS, 2009)

QUASE todos os seus órgãos deliberativos (FACULDADE DE DIREITO, 2009)

em QUASE todos os cenários (INSTITUTO DE MATEMÁTICA E ESTATÍSTICA, 2009) 
Nos experimentos com anteparos, observou-se escolha QUASE que total da alternativa sem anteparo ou com anteparo transparente (AA, AB e AT) (INSTITUTO DE PSICOLOGIA, 2009)

em QUASE todas as populações afro-descendentes (INSTITUTO DE BIOCIÊNCIAS, 2009)

QUASE três séculos (INSTITUTO DE MATEMÁTICA E ESTATÍSTICA, 2009)

coinfectados QUASE nunca ou às vezes procuram o posto de saúde (...) e os doentes com TB QUASE sempre procuram o posto de saúde (...) e os doentes coinfectados QUASE nunca realizam o tratamento (ESCOLA DE ENFERMAGEM, 2009)

em regime QUASE estático (ESCOLA POLITÉCNICA, 2009)

direitos de QUASE-propriedade (FACULDADE DE DIREITO, 2009)

foi QUASE completamente bloqueada (FACULDADE DE MEDICINA, 2009)

QUASE sempre, (FACULDADE DE FILOSOFIA, LETRAS E CIÊNCIAS HUMANAS, 2009)

QUASE todos os alvos (GEOINSTITUTO DE FÍSICA, 2009)

perda da estrutura QUASE-periódica dos sinais (ESCOLA DE ENGENHARIA DE SÃO CARLOS, 2009)

QUASE todos os egressos (...) QUASE sempre está (...) QUASE todos os sujeitos (...) o trabalho, em suas vidas, representou QUASE que somente uma estratégia de sobrevivência: o acesso ao universo produtivo sempre foi limitado, tomando-se ainda mais difícil após o episódio da prisão. (INSTITUTO DE PSICOLOGIA, 2009)

QUASE dois terços dos trabalhos (INSTITUTO DE PSICOLOGIA, 2009)

QUASE sempre (FACULDADE DE FILOSOFIA, LETRAS E CIÊNCIAS HUMANAS, 2009)

foi QUASE total (ESCOLA POLITÉCNICA, 2009)

QUASE sempre (FACULDADE DE FILOSOFIA, LETRAS E CIÊNCIAS HUMANAS, 2009)

de QUASE a totalidade dos educadores (FACULDADE DE SAÚDE PÚBLICA, 2009)

QUASE todas compostas (FACULDADE DE FILOSOFIA, LETRAS E CIÊNCIAS HUMANAS, 2009)

QUASE completa (FACULDADE DE ODONTOLOGIA, 2009)

indicou uma concordância QUASE perfeita $(0,83)$ (FACULDADE DE EDUCAÇÃO, 2009) 
QUASE nula (ESCOLA SUPERIOR DE AGRICULTURA “LUIZ DE QUEIROZ”, 2009)

um processo QUASE-reversível (FACULDADE DE CIÊNCIAS FARMACÊUTICAS DE RIBEIRÃO PRETO, 2009)

de categoria QUASE coincidente (INSTITUTO DE PSICOLOGIA, 2009)

QUASE 40 por cento (FACULDADE DE SAÚDE PÚBLICA, 2009)

em QUASE uma década (FACULDADE DE SAÚDE PÚBLICA, 2009)

QUASE nula. (INSTITUTO DE GEOCIÊNCIAS, 2009)

Em QUASE sua totalidade (INSTITUTO DE BIOCIÊNCIAS, 2009)

QUASE linear (FACULDADE DE FILOSOFIA, CIÊNCIAS E LETRAS DE RIBEIRÃO PRETO, 2009)

como QUASE todas (FACULDADE DE ARQUITETURA E URBANISMO, 2009)

delineamento QUASE-experimental (ESCOLA DE ENFERMAGEM, 2009)

QUASE todas as populações (INSTITUTO DE BIOCIÊNCIAS, 2009)

foi encontrada uma concordância QUASE perfeita $(\mathrm{k}=0,81)$ (HRAC -- HOSPITAL REABILITAO DE ANOMALIAS CRANIOFACIAIS, 2009)

comportamentos de agentes QUASE-racionais (FACULDADE DE ECONOMIA, ADMINISTRAÇÃO E CONTABILIDADE, 2009)

Foram descritivo e QUASE-experimental (ESCOLA DE ENFERMAGEM, 2009)

comportamento QUASE linear (ESCOLA POLITÉCNICA, 2009)

QUASE metade das receitas (ESCOLA SUPERIOR DE AGRICULTURA "LUIZ DE QUEIROZ”, 2008)

QUASE sempre (FACULDADE DE FILOSOFIA, LETRAS E CIÊNCIAS HUMANAS, 2008)

No entanto, o IMPAC reduziu em QUASE $50 \%$ o tempo de análise (ESCOLA SUPERIOR DE AGRICULTURA “LUIZ DE QUEIROZ”, 2008)

Em QUASE todas as CTM- TF, (FACULDADE DE MEDICINA, 2008)

diluiu QUASE totalmente o CO2 (INSTITUTO DE GEOCIÊNCIAS, 2008)

QUASE um século (ESCOLA DE COMUNICAÇÃO E ARTES, 2008)

QUASE 11 milhões de habitantes (ESCOLA POLITÉCNICA, 2008)

Em relação a padrões comportamentais masculinos e femininos no relacionamento, QUASE não foram encontradas diferenças entre Brasil e Itália. (INSTITUTO DE PSICOLOGIA, 2008) 
essas ações consolidada QUASE uma década depois da publicação (FACULDADE DE DIREITO, 2008)

o aumento da QUASE-moeda. (FACULDADE DE ECONOMIA, ADMINISTRAÇÃO E CONTABILIDADE, 2008)

O estudo é QUASE experimental (FACULDADE DE SAÚDE PÚBLICA, 2008)

É QUASE ausente (FACULDADE DE MEDICINA, 2008)

ambiente QUASE anímico, encantado, (FACULDADE DE FILOSOFIA, LETRAS E CIÊNCIAS HUMANAS, 2008)

Por outro lado, a relação de seus trabalhos com temas políticos foi QUASE nula durante os anos duros do mais agressivo ato institucional o $5^{\circ}$ (FACULDADE DE FILOSOFIA, LETRAS E CIÊNCIAS HUMANAS, 2008)

QUASE a metade era solteira (ESCOLA DE ENFERMAGEM, 2008)

QUASE 40\% (FACULDADE DE MEDICINA, 2008)

QUASE 30\% (ESCOLA DE ENFERMAGEM, 2008)

QUASE 80\% (FACULDADE DE MEDICINA, 2008)

QUASE o dobro de sementes (INSTITUTO DE BIOCIÊNCIAS, 2008)

QUASE 34.000 horas-rede (INSTITUTO DE BIOCIÊNCIAS, 2008)

QUASE 10\% da população feminina (FACULDADE DE ECONOMIA, ADMINISTRAÇÃO E CONTABILIDADE, 2008)

QUASE a metade está desempregado (ESCOLA DE ENFERMAGEM, 2008)

cisalhamento QUASE-nulo e de cisalhamento negativo (INSTITUTO DE FÍSICA, 2008)

QUASE metade alega doença de sono (...) drogas na família foram relatadas para QUASE $20 \%$ (ESCOLA DE ENFERMAGEM, 2008)

QUASE duzentas monografias, (FACULDADE DE FILOSOFIA, LETRAS E CIÊNCIAS HUMANAS, 2008)

QUASE 200 vezes maior (INSTITUTO DE BIOMÉDICAS, 2008)

QUASE três vezes mais que a atmosfera (INSTITUTO DE QUÍMICA, 2008)

inibidas em QUASE 50 por cento (INSTITUTO DE QUÍMICA, 2008)

QUASE sempre (FACULDADE DE FILOSOFIA, LETRAS E CIÊNCIAS HUMANAS, 2008)

A fase 1 da pesquisa, que avaliou o desempenho dos filtros anaeróbios quando operados em série, indicou que a QUASE totalidade da remoção de matéria orgânica (ESCOLA DE ENGENHARIA DE SÃO CARLOS, 2008) 
que referencia QUASE todos os tipos de unidades (ESCOLA POLITÉCNICA, 2008)

presente em QUASE toda a extensão da obra (FACULDADE DE FILOSOFIA, LETRAS E CIÊNCIAS HUMANAS, 2008)

QUASE todo o estudo feito pela escassa doutrina brasileira (FACULDADE DE DIREITO, 2008)

QUASE sempre (FACULDADE DE DIREITO, 2008)

em QUASE todo o continente foi simulado (INSTITUTO DE INSTITUTO DE ASTRONOMIA, GEOINSTITUTO DE FÍSICA E CIÊNCIAS ATMOSFÉRICAS, 2008)

em QUASE todos os estados (ESCOLA SUPERIOR DE AGRICULTURA “LUIZ DE QUEIROZ”, 2008)

quando do fechamento QUASE total dos mercados externos (ESCOLA SUPERIOR DE AGRICULTURA “LUIZ DE QUEIROZ”, 2008)

QUASE todos os tipos de atividade (FACULDADE DE ECONOMIA, ADMINISTRAÇÃO E CONTABILIDADE, 2008)

em QUASE todos os tipos de inovação (FACULDADE DE ECONOMIA, ADMINISTRAÇÃO E CONTABILIDADE, 2008)

QUASE todos (ESCOLA DE COMUNICAÇÃO E ARTES, 2008)

Em QUASE a totalidade dos trabalhos, (FACULDADE DE MEDICINA, 2008)

QUASE sempre (INSTITUTO DE MATEMÁTICA E ESTATÍSTICA, 2008)

ou QUASE todos os dias (ESCOLA DE ENFERMAGEM, 2008)

QUASE todas ${ }^{171}$ as espécies (FACULDADE DE MEDICINA VETERINÁRIA E ZOOTECNIA, 2008)

QUASE todas as amostras (ESCOLA POLITÉCNICA, 2008)

QUASE todas as classes de tamanho (INSTITUTO DE BIOCIÊNCIAS, 2008)

QUASE todos os espécimes (FACULDADE DE ODONTOLOGIA, 2008)

em QUASE todas as medidas (FACULDADE DE MEDICINA, 2008)

de QUASE todas as disfunções. (FACULDADE DE ODONTOLOGIA, 2008)

e QUASE total inexistência de erros (ESCOLA POLITÉCNICA, 2008)

QUASE sempre (INSTITUTO DE BIOCIÊNCIAS, 2008)

em QUASE toda a faixa do espectro visível, (ESCOLA POLITÉCNICA, 2008)

${ }^{171}$ Foram duas ocorrências deste dado neste resumo. 
Em QUASE todas as amostras de cana-de-açúcar

(ESCOLA SUPERIOR DE AGRICULTURA “LUIZ DE QUEIROZ”, 2008)

que levaram à sua QUASE total destruição (FACULDADE DE FILOSOFIA, LETRAS E CIÊNCIAS HUMANAS, 2008)

QUASE sempre acompanhada (...) QUASE sempre não são reconhecidas em exames convencionais ao microscópio. (INSTITUTO DE GEOCIÊNCIAS, 2008)

dado que estes elementos suportam QUASE toda a carga (ESCOLA POLITÉCNICA, 2008)

QUASE todo o território de Montanha (FACULDADE DE FILOSOFIA, LETRAS E CIÊNCIAS HUMANAS, 2008)

QUASE sempre (ESCOLA POLITÉCNICA, 2008)

em QUASE todos os testes aplicados (FACULDADE DE MEDICINA, 2008)

em QUASE todos os regimes (ESCOLA DE ENGENHARIA DE SÃO CARLOS, 2008)

em QUASE todas as etapas (FACULDADE DE MEDICINA, 2008)

ao longo de QUASE toda a vida adulta (FACULDADE DE MEDICINA, 2008)

Uma ausência QUASE total de material conchífero, (MUSEU DE ARQUEOLOGIA E ETNOLOGIA, 2008)

QUASE todos aqueles que apresentaram (FACULDADE DE MEDICINA, 2008)

QUASE todas (exceto RhoC) (INSTITUTO DE BIOMÉDICAS, 2008)

QUASE todos os casos (FACULDADE DE ODONTOLOGIA, 2008)

em que pese a sua QUASE total obscuridade (FACULDADE DE FILOSOFIA, LETRAS E CIÊNCIAS HUMANAS, 2008)

Em QUASE todos os pacientes (FACULDADE DE MEDICINA, 2008)

A QUASE totalidade dos países ocidentais (FACULDADE DE DIREITO, 2008)

Em QUASE todos os passos (ESCOLA DE ENFERMAGEM, 2008)

de QUASE todas as espécies (FACULDADE DE FILOSOFIA, LETRAS E CIÊNCIAS HUMANAS DE RIBEIRÃO PRETOS, 2008)

Para a QUASE totalidade dos pacientes (FACULDADE DE MEDICINA, 2008)

em QUASE todos os ambientes (ESCOLA POLITÉCNICA, 2008)

O estudo da acústica de salas data do início do século XX e, até então, esta atividade era vista QUASE como uma arte e não como ciência. (INSTITUTO DE MATEMÁTICA E ESTATÍSTICA, 2008) 
Os professores QUASE sempre utilizam (FACULDADE DE EDUCAÇÃO, 2008)

em geral, manifestas em crises que se propagam para a QUASE totalidade da produção (ESCOLA DE ENGENHARIA DE SÃO CARLOS, 2008)

estando QUASE todos na fase de resistência, (FACULDADE DE MEDICINA, 2008)

QUASE sempre (...) (INSTITUTO DE PSICOLOGIA, 2008)

QUASE todos os sujeitos (INSTITUTO DE PSICOLOGIA, 2008)

QUASE todos os egressos (INSTITUTO DE PSICOLOGIA, 2008)

QUASE todas as estimações realizadas. (FACULDADE DE ECONOMIA, ADMINISTRAÇÃO E CONTABILIDADE, 2008)

QUASE sempre (FACULDADE DE EDUCAÇÃO, 2008)

QUASE sempre (ESCOLA POLITÉCNICA, 2008)

QUASE sempre (FACULDADE DE FILOSOFIA, LETRAS E CIÊNCIAS HUMANAS, 2008)

QUASE dez anos de intervalo. Assim, em QUASE dez anos, (FACULDADE DE MEDICINA, 2008)

QUASE um século (ESCOLA DE COMUNICAÇÃO E ARTES, 2008)

QUASE uma década, (INSTITUTO DE PSICOLOGIA, 2008)

há QUASE 10 anos (ESCOLA SUPERIOR DE AGRICULTURA "LUIZ DE QUEIROZ”, 2008)

QUASE quatro décadas (ESCOLA DE ENGENHARIA DE SÃO CARLOS, 2008)

há QUASE meio século (ESCOLA DE ENGENHARIA DE SÃO CARLOS, 2008)

há QUASE três décadas (FACULDADE DE MEDICINA, 2008)

é QUASE totalmente diferente (FACULDADE DE ODONTOLOGIA, 2008)

QUASE totalmente no citosol celular. (FACULDADE DE MEDICINA, 2008)

O DNA mitocondrial das populações brasileiras de abelhas africanizadas apresentouse QUASE que totalmente como sendo de origem africana à exceção de três colônias que apresentaram DNA mitocondrial ) como sendo de origem de subespécies do leste europeu. (FACULDADE DE MEDICINA, 2008)

A condição dekassegui, em grande medida, instaura desenraizamento a) por QUASE deter o indivíduo no regime alienante (INSTITUTO DE PSICOLOGIA, 2008)

apresentasse QUASE ou totalmente dessemantizado (FACULDADE DE FILOSOFIA, LETRAS E CIÊNCIAS HUMANAS, 2008) 
verbos QUASE seriais ou de verbos seriais (FACULDADE DE FILOSOFIA, LETRAS E CIÊNCIAS HUMANAS, 2008)

álgebras QUASE-hereditárias. (INSTITUTO DE MATEMÁTICA E ESTATÍSTICA, 2008)

QUASE universal (FACULDADE DE DIREITO, 2008)

QUASE-estacionário ${ }^{172}$ (ESCOLA POLITÉCNICA, 2008)

QUASE-estacionário (INSTITUTO DE QUÍMICA, 2008)

QUASE constantes (INSTITUTO DE GEOCIÊNCIAS, 2008)

QUASE perfeita (FACULDADE DE MEDICINA, 2008)

e QUASE ameaçadas de extinção (INSTITUTO DE BIOCIÊNCIAS, 2008)

QUASE global (INSTITUTO DE GEOCIÊNCIAS, 2008)

QUASE estequiométrico (ESCOLA POLITÉCNICA, 2008)

QUASE-sinóticos (INSTITUTO OCEANOGRÁFICO, 2008)

QUASE semelhantes às das favelas (ESCOLA DE ENGENHARIA DE SÃO CARLOS, 2008)

sistema QUASE ideal (ESCOLA SUPERIOR DE AGRICULTURA "LUIZ DE QUEIROZ”, 2008)

fenômenos QUASE-periódicos (...) QUASE-periódicas (INSTITUTO DE ASTRONOMIA, GEOFÍSICA E CIÊNCIAS ATMOSFÉRICAS, 2008)

convergência QUASE minimax (INSTITUTO DE MATEMÁTICA E ESTATÍSTICA, 2008)

Por sua escrita límpida, fluída, QUASE "manzoniana" (FACULDADE DE FILOSOFIA, LETRAS E CIÊNCIAS HUMANAS, 2008)

QUASE estequiométrico ${ }^{173}$ (ESCOLA POLITÉCNICA, 2008)

ausência QUASE absoluta (ESCOLA POLITÉCNICA, 2008)

QUASE perfeita (FACULDADE DE ODONTOLOGIA, 2008)

QUASE desconhecida (FACULDADE DE FILOSOFIA, LETRAS E CIÊNCIAS HUMANAS, 2008)

QUASE-experimental (ESCOLA DE ENFERMAGEM, 2008)

QUASE azeotrópica (ESCOLA POLITÉCNICA, 2008)

\footnotetext{
${ }^{172}$ Foram quatro ocorrências deste dado neste resumo.

${ }^{173}$ Foram duas ocorrências deste dado neste resumo.
} 
diálogos QUASE-espontâneos, (FACULDADE DE FILOSOFIA, LETRAS E CIÊNCIAS HUMANAS, 2008)

coleta foi QUASE inalterada (ESCOLA SUPERIOR DE AGRICULTURA “LUIZ DE QUEIROZ”, 2008)

QUASE elástico $^{174}$ (INSTITUTO DE FÍSICA, 2008)

O PFI e SFI, e o TFI e SFI apresentaram uma força de concordância QUASE perfeita (FACULDADE DE MEDICINA, 2008)

amostragem QUASE-sinótica (INSTITUTO OCEANOGRÁFICO, 2008)

textos QUASE inalterados, (FACULDADE DE FILOSOFIA, LETRAS E CIÊNCIAS HUMANAS, 2008)

uma rede QUASE contínua (ESCOLA POLITÉCNICA, 2008)

QUASE inclinada (INSTITUTO DE MATEMÁTICA E ESTATÍSTICA, 2008)

um modelo de QUASE-verossimilhança (INSTITUTO DE MATEMÁTICA E ESTATÍSTICA, 2008)

condições de QUASE-continuidade ou descontinuidade (INSTITUTO OCEANOGRÁFICO, 2008)

QUASE-sinopticidade da aquisição dos dados (INSTITUTO OCEANOGRÁFICO, 2008)

Os Pilotos e Cadetes Oficiais Aviadores da Força Aérea Brasileira são expostos QUASE que diariamente ao aumento da força da gravidade, força $\mathrm{G}$. (FACULDADE DE MEDICINA DE RIBEIRÃO PRETO, 2008)

As associações sabor-local, a seqüência das associações, os locais do pareamento e a amostra oferecida antes da terceira tentativa, variaram QUASE aleatoriamente a cada dia. (INSTITUTO DE BIOCIÊNCIAS, 2008)

O QUASE perfeitamente gaussiana (INSTITUTO DE GEOCIÊNCIAS, 2008

no método QUASE-Newton (ESCOLA POLITÉCNICA, 2008)

existe QUASE uma lacuna na investigação teórica (FACULDADE DE FILOSOFIA, LETRAS E CIÊNCIAS HUMANAS, 2008)

resignação pela "QUASE extinção" das obstetrizes (ESCOLA DE ENFERMAGEM, 2008)

e QUASE significância para a cor branca (ESCOLA DE ENFERMAGEM, 2008)

QUASE-renda (FACULDADE DE ECONOMIA, ADMINISTRAÇÃO E CONTABILIDADE, 2008)

${ }^{174}$ Foram duas ocorrências deste dado neste resumo. 
bem como QUASE-periodicidades (INSTITUTO DE ASTRONOMIA, GEOFÍSICA E CIÊNCIAS ATMOSFÉRICAS, 2008)

Participam às vezes ou QUASE nunca (ESCOLA DE ENFERMAGEM, 2008)

e uma redução moderada é observada para o sistema TMPyP-HPS e QUASE nenhuma mudança é vista para a TMPyP na presença de TX-100. (INSTITUTO DE QUÍMICA, 2008)

A inclusão de recursos do PROMED e da comunidade aos recursos oficiais advindos dos impostos não muda em QUASE nada o cenário da escassez, dado os montantes serem irrisórios,(FACULDADE DE EDUCAÇÃ̃, 2008)

Os resultados QUASE-3D (...) QUASE-2D (INSTITUTO DE ASTRONOMIA, GEOFÍSICA E CIÊNCIAS ATMOSFÉRICAS, 2008)

QUASE 3-D. (INSTITUTO DE ASTRONOMIA, GEOFÍSICA E CIÊNCIAS ATMOSFÉRICAS, 2007)

Colletotrichum gossypii var. cephalosporioides, fungo causador da ramulose do algodoerio, é ocorre disperso em QUASE todo Brasil. (ESCOLA SUPERIOR DE AGRICULTURA “LUIZ DE QUEIROZ”, 2007)

por QUASE todas as mulheres (ESCOLA DE ENFERMAGEM, 2007)

dos adolescentes pesquisados. Estes, em QUASE sua totalidade, entendem a adolescência como fase de crescimento e nova (ESCOLA DE ENFERMAGEM, 2007)

com escolaridade média, em termos de número de anos no Ensino Fundamental, de 4,9 anos ( $\mathrm{DP}=2,8)$, isto é, QUASE 5a. série ${ }^{175}$, com mínimo de 1 ano e máximo de 12 anos de escolaridade, ou seja, Ensino Superior. (INSTITUTO DE PSICOLOGIA, 2007)

em QUASE todos os relatos (INSTITUTO DE PSICOLOGIA, 2007)

a remoção QUASE total de ninfas num determinado espaço. (ESCOLA SUPERIOR DE AGRICULTURA “LUIZ DE QUEIROZ”, 2007)

o seu poder coativo sobre QUASE a totalidade dos cidadãos (FACULDADE DE DIREITO, 2007)

Crê-se que QUASE toda a mobilidade humana mundial acha-se inserida na história das imigrações (FACULDADE DE FILOSOFIA, LETRAS E CIÊNCIAS HUMANAS, 2007)

Em QUASE todos os pontos estudados (INSTITUTO DE QUÍMICA, 2007)

outras formas de dispersão, como frústulas e pólipos desprendidos, podem fixar-se e crescer em QUASE qualquer animal macroscópico do bentos marinho (INSTITUTO DE BIOCIÊNCIAS, 2007)

O número de substâncias cuja redução do LEO é igual ou superior a 50`POR CENTO' corresponde à QUASE totalidade das reduções (INSTITUTO DE QUÍMICA, 2007)

${ }^{175}$ Foram duas ocorrências deste dado neste resumo. 
O fator inquietante é a preocupação dos futuros moradores, em sua QUASE maioria, para que estejam sempre alinhados aos anseios do mercado imobiliário, independentemente de seu real programa de necessidades. (FACULDADE DE ARQUITETURA E URBANISMO, 2007)

de QUASE todas as táticas (INSTITUTO DE PSICOLOGIA, 2007)

O melhoramento do alho (AIIium sativum L.) está limitado à seleção clonal de genótipos mutantes, uma vez que a QUASE totalidade do germoplasma da espécie é sexualmente estéril (FACULDADE DE FILOSOFIA, LETRAS E CIÊNCIAS HUMANAS DE RIBEIRÃO PRETOS, 2007)

QUASE sempre (INSTITUTO DE PSICOLOGIA, 2007)

em QUASE todo o litoral brasileiro (INSTITUTO DE QUÍMICA, 2007)

QUASE sempre (INSTITUTO DE FÍSICA, 2007)

QUASE sempre (FACULDADE DE FILOSOFIA, LETRAS E CIÊNCIAS HUMANAS, 2007)

Além disso, dentes que apresentaram bisel em todo o ângulo cavo-superficial de cavidades de Classe II, tanto com ou sem intervenção endodôntica, mostraram os melhores padrões de fratura, preservando QUASE que em sua totalidade a integridade do remanescente dentário (FACULDADE DE ODONTOLOGIA, 2007)

ocorreu diminuição de 13 QUASE todos os peridonto patógenos, (FACULDADE DE MEDICINA, 2007)

QUASE todos os processos (INSTITUTO DE QUÍMICA, 2007)

foi QUASE três vezes (FACULDADE DE SAÚDE PÚBLICA, 2007)

que podem chegar a QUASE 100\% de clinopiroxenito (INSTITUTO DE GEOCIÊNCIAS, 2007)

foi QUASE 10 vezes menor (FACULDADE DE MEDICINA, 2007)

QUASE 80\% da inervação (FACULDADE DE MEDICINA, 2007)

QUASE 100\% do total da bacia (INSTITUTO DE GEOCIÊNCIAS, 2007)

Foi utilizada a discretização de inclusões muito esbeltas com rigidez QUASE nula visando a simular o comportamento de uma região de fratura elástica. (ESCOLA DE ENGENHARIA DE SÃO CARLOS, 2007)

QUASE $5 \mathrm{~kb}$ foi clonada. (INSTITUTO DE BIOCIÊNCIAS, 2007)

QUASE 20\% das sequências (INSTITUTO DE BIOCIÊNCIAS, 2007)

QUASE metade deles (ESCOLA DE COMUNICAÇÃO E ARTES, 2007)

QUASE 90\% da produção (ESCOLA DE ENGENHARIA DE SÃO CARLOS, 2007) 
QUASE 16\% do total (ESCOLA SUPERIOR DE AGRICULTURA "LUIZ DE QUEIROZ”, 2007)

QUASE três vezes maior (FACULDADE DE CIÊNCIAS FARMACÊUTICAS DE RIBEIRÃO PRETO, 2007)

Hoje a EdC encontra-se dispersa por cerca de 40 países envolvendo QUASE 800 empresas. (ESCOLA DE COMUNICAÇÃO E ARTES, 2007)

há QUASE duzentos anos, (FACULDADE DE DIREITO, 2007)

QUASE quinze anos (FACULDADE DE ECONOMIA, ADMINISTRAÇÃO E CONTABILIDADE, 2007)

durante QUASE oito milênios (MUSEU DE ARQUEOLOGIA E ETNOLOGIA, 2007) por QUASE meio século (FACULDADE DE FILOSOFIA, LETRAS E CIÊNCIAS HUMANAS, 2007)

há QUASE duzentos anos (FACULDADE DE FILOSOFIA, LETRAS E CIÊNCIAS HUMANAS, 2007)

Por exemplo, durante QUASE todo o século XIX (FACULDADE DE EDUCAÇÃO, 2007)

há QUASE 15 anos (INSTITUTO DE MATEMÁTICA E ESTATÍSTICA, 2007)

Os resultados obtidos certamente ampliaram o conhecimento sobre os solos presentes no entorno de lagoas salinas, uma vez os estudos disponíveis na literatura são baseados QUASE que exclusivamente em dados de campo. (FACULDADE DE FILOSOFIA, LETRAS E CIÊNCIAS HUMANAS, 2007)

No Brasil emprega-se, QUASE que exclusivamente, o $\mathrm{N}$ do SPT para o cálculo e estimativa da capacidade de carga e recalques em estacas. (ESCOLA POLITÉCNICA, 2007)

esporte contemporâneo tem nos Jogos Olímpicos o seu maior evento e sua evolução na Era Moderna QUASE que completamente durante o Século XX. (FACULDADE DE EDUCAÇÃO INSTITUTO DE FÍSICA, 2007)

motivação QUASE completamente econômica (FACULDADE DE FILOSOFIA, LETRAS E CIÊNCIAS HUMANAS, 2007)

O povo, quando aparece, é mero figurante - muitas vezes, ridicularizado - no cenário cujos protagonistas são, QUASE inexoravelmente, os donos do poder. (ESCOLA DE COMUNICAÇÃO E ARTES, 2007)

que afeta QUASE exclusivamente o sexo feminino (FACULDADE DE MEDICINA, 2007)

que permitiu um grande desenvolvimento na qualidade deste produto, sua utilização ainda está restrita QUASE que exclusivamente a um procedimento artesanal, cuja qualidade final depende da qualidade da mão-de-obra. (ESCOLA DE ENGENHARIA DE SÃO CARLOS, 2007) 
T. evansi apresentou uma ampla distribuição, ) enquanto P. longipes foi encontrado QUASE que exclusivamente na zona urbana de Uruguaiana e em associação com T. evansi. (ESCOLA SUPERIOR DE AGRICULTURA "LUIZ DE QUEIROZ", 2007)

As pesquisas direcionadas às mulheres a respeito deste tema preocupavamse QUASE exclusivamente com os problemas de caráter reprodutivo e doenças ginecológicas. (INSTITUTO DE QUÍMICA, 2007)

Estudo comparativo com outras ocorrências alcalinas brasileiras formadas QUASE que exclusivamente de litologias sieníticas permite reconhecer similaridades entre as rochas de Cananéia e aquelas que alguns maciços da Província da Serra do Mar (Serra da Mantiqueira (INSTITUTO DE GEOCIÊNCIAS, 2007)

fatores sociais, econômicos e pessoais que envolvem estes profissionais, QUASE o tornam inatingível. (ESCOLA DE ENFERMAGEM, 2007)

Em vários momentos, a tradição QUASE sucumbiu na luta pela sua manutenção diante do processo urbano-industrial, que fragmenta a vida e enfraquece as relações próximas. (FACULDADE DE FILOSOFIA, LETRAS E CIÊNCIAS HUMANAS, 2007)

são QUASE inexistentes. (ESCOLA SUPERIOR DE AGRICULTURA "LUIZ DE QUEIROZ", 2007)

QUASE inexistente (ESCOLA DE ENFERMAGEM, 2007)

em QUASE completo esquecimento (FACULDADE DE FILOSOFIA, LETRAS E CIÊNCIAS HUMANAS, 2007)

QUASE aleatórios. (INSTITUTO DE FÍSICA, 2007)

em doses QUASE letais, (ESCOLA SUPERIOR DE AGRICULTURA "LUIZ DE QUEIROZ”, 2007)

QUASE-estáticos (ESCOLA DE ENGENHARIA DE SÃO CARLOS, 2007)

numa relação QUASE direta (FACULDADE DE EDUCAÇÃO, 2007)

QUASE-geostrófico $^{176}$ (INSTITUTO OCEANOGRÁFICO, 2007)

QUASE-geostrófico ${ }^{177}$ (INSTITUTO OCEANOGRÁFICO, 2007)

QUASE-experimental (ESCOLA DE ENFERMAGEM, 2007)

É QUASE certo um papel protetor (FACULDADE DE MEDICINA, 2007)

QUASE- estável (INSTITUTO DE ASTRONOMIA, GEOINSTITUTO DE FÍSICA E CIÊNCIAS ATMOSFÉRICAS, 2007)

cuja melhor solução é o governo "QUASE régio", (FACULDADE DE FILOSOFIA, LETRAS E CIÊNCIAS HUMANAS, 2007)

\footnotetext{
${ }^{176}$ Foram duas ocorrências deste dado neste resumo.

${ }^{177}$ Foram duas ocorrências deste dado neste resumo.
} 
No entanto, algumas destas redes, como as de sensores com funcionamento intermitente, redes periódicas ou cíclicas e as do sistema de satélites de órbita baixa têm um comportamento dinâmico relativamente previsível, pois as variações da topologia da rede no tempo são QUASE que determinísticas. (INSTITUTO DE MATEMÁTICA E ESTATÍSTICA, 2007)

foi QUASE abolida (INSTITUTO DE QUÍMICA, 2007)

foi de 0,905, ou seja, QUASE perfeita (FACULDADE DE MEDICINA, 2007)

QUASE-experimental, (ESCOLA DE ENFERMAGEM, 2007)

QUASE periódicas (INSTITUTO DE MATEMÁTICA E ESTATÍSTICA, 2007)

Quando se observou separadamente cada classe de tamanho neste ambiente, verificouse baixa estruturação na classe dos jovens, e uma disposição QUASE que aleatória dos genótipos na classe dos adultos. (ESCOLA SUPERIOR DE AGRICULTURA "LUIZ DE QUEIROZ”, 2007)

QUASE exclusiva (FACULDADE DE ECONOMIA, ADMINISTRAÇÃO E CONTABILIDADE, 2007)

reversão QUASE completa (88\%) (FACULDADE DE MEDICINA, 2007)

QUASE ventral (INSTITUTO DE BIOCIÊNCIAS, 2007)

QUASE-elásticas $^{178}$ (INSTITUTO DE FÍSICA, 2007)

QUASE-isogênicas (ESCOLA SUPERIOR DE AGRICULTURA "LUIZ DE QUEIROZ", 2007)

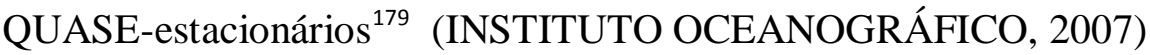

QUASE-singulares ${ }^{180}$ (ESCOLA POLITÉCNICA, 2007)

QUASE experimental ${ }^{181}$ (INSTITUTO DE PSICOLOGIA, 2007)

um perfil unidirecional QUASE-senoidal (ESCOLA POLITÉCNICA, 2007)

QUASE pura (INSTITUTO DE GEOCIÊNCIAS, 2007)

medições QUASE-sinóticas (INSTITUTO OCEANOGRÁFICO, 2007)

O método utilizado para estimar o atraso escolar foi a QUASE verossimilhança em dois estágios (FACULDADE DE ECONOMIA, ADMINISTRAÇÃO E CONTABILIDADE, 2007)

QUASE renda. (FACULDADE DE ECONOMIA, ADMINISTRAÇÃO E CONTABILIDADE, 2007)

\footnotetext{
${ }^{178}$ Foram seis ocorrências deste dado neste resumo.

${ }^{179}$ Foram duas ocorrências deste dado neste resumo.

${ }^{180}$ Foram três ocorrências deste dado neste resumo.

${ }^{181}$ Foram duas ocorrências deste dado neste resumo.
} 
periodicidade, QUASE-periodicidade, estabilidade (INSTITUTO DE MATEMÁTICA E ESTATÍSTICA, 2007)

QUASE-periodicidade (INSTITUTO DE FÍSICA, 2007)

a conclusão será avaliado o conceito de sociedade aberta agora sob a amplitude de ser um modo de reunir autores que, apesar de suas diferenças e certamente sem terem realizado qualquer orquestração maior de suas idéias políticas, podem ser tratados como formando QUASE que uma ?escola austríaca? de defesa de uma certa interpretação da democracia. (FACULDADE DE FILOSOFIA, LETRAS E CIÊNCIAS HUMANAS, 2007)

mesmo sendo QUASE um padrão amazônico, (FACULDADE DE FILOSOFIA, LETRAS E CIÊNCIAS HUMANAS, 2007)

QUASE-verossimilhança (INSTITUTO DE MATEMÁTICA E ESTATÍSTICA, 2007)

Tutaméia é \"ninharial", ।"QUASE nadal" (FACULDADE DE FILOSOFIA, LETRAS E CIÊNCIAS HUMANAS, 2007)

isto é, o cromo, na forma de óxi-hidróxido, se manteve precipitado junto às partículas do solo; o cobre, pouco ou QUASE nada se alterou, (INSTITUTO DE GEOCIÊNCIAS, 2007)

Durante este período, os fluxos de material orgânico particulado (MOP) estão entre os mais elevados do oceano, enquanto que pouco ou QUASE nada é exportado no período coberto por gelo. (INSTITUTO OCEANOGRÁFICO, 2007)

Durante sua existência, o número de contratos futuros negociado na BMSP mostrou enormes flutuações, com alguns anos QUASE sem negócios, e em outros com um volume de contratos representando quantidades superiores à própria safra. (ESCOLA SUPERIOR DE AGRICULTURA “LUIZ DE QUEIROZ”, 2007)

Confirmou-se mais uma vez que o ESCOLA POLITÉCNICAetileno é um material QUASE não biodegradável (ESCOLA SUPERIOR DE AGRICULTURA "LUIZ DE QUEIROZ", 2007)

O que as reportagens QUASE nunca apresentavam (FACULDADE DE FILOSOFIA, LETRAS E CIÊNCIAS HUMANAS, 2007)

Hoje QUASE inseparavelmente ligados (FACULDADE DE DIREITO, 2007)

As memórias das mulheres são transcritas QUASE que literalmente, numa tentativa de apresentar ao leitor os nexos criados por elas entre educação e movimento popular, (FACULDADE DE EDUCAÇÃO, 2007)

As drogas causaram um claro efeito antipânico, diminuindo a elaboração de comportamentos defensivos, como alerta e congelamento, e aumentando as respostas comportamentais não defensivas, como autolimpeza e repouso, os quais foram evocados QUASE que invariavelmente nas proximidades do predador, o que sugere comportamento destemido. (FACULDADE DE MEDICINA DE RIBEIRÃO PRETO, 2007) 
Em VENTO, as células Tropicais e Subtropicais (TCs e STCs) foram geradas, e elas alimentaram a ressurgência equatorial QUASE simetricamente pelo norte e polo sul. (INSTITUTO OCEANOGRÁFICO, 2006)

elas são responsáveis pela QUASE totalidade de empresas formalmente existentes nos setores (FACULDADE DE DIREITO, 2006)

pois todos ou QUASE todos falavam a língua tupi (FACULDADE DE FILOSOFIA, LETRAS E CIÊNCIAS HUMANAS, 2006)

em QUASE todos os domínios d (FACULDADE DE MEDICINA, 2006)

Para QUASE todas as amostras, (FACULDADE DE MEDICINA VETERINÁRIA E ZOOTECNIA, 2006)

na QUASE totalidade das amostras, (ESCOLA SUPERIOR DE AGRICULTURA "LUIZ DE QUEIROZ", 2006)

com QUASE todos os demais, (ESCOLA SUPERIOR DE AGRICULTURA "LUIZ DE QUEIROZ", 2006)

QUASE sempre (INSTITUTO DE PSICOLOGIA, 2006)

SDS-PAGE mostraram que subunidades HEX 70b permanecem acumuladas em grande quantidade na hemolinfa pelo menos até a fase de pupa de pigmentação cuticular intermediária, QUASE ao final do estágio pupal, e então diminuem progressivamente. (FACULDADE DE FILOSOFIA, CIÊNCIAS E LETRAS DE RIBEIRÃO PRETO, 2006)

verificou-se que as escolas que fizeram parte da amostra da pesquisa adotam, para a QUASE totalidade dos alunos, a concepção de avaliação utilizada na Lei de Diretrizes e Bases da Educação (Lei n 9394/96) (FACULDADE DE EDUCAÇÃO, 2006)

consideravelmente mais complexa, já que o setor tem características e especificidades únicas. O modelo anterior sob o qual o setor havia se desenvolvido, a partir da década de 1960, estatal em sua QUASE totalidade, começou a ser desmontado inviabilizou-se. (FACULDADE DE FILOSOFIA, LETRAS E CIÊNCIAS HUMANAS, 2006)

QUASE todos os mamíferos (INSTITUTO DE BIOMÉDICAS, 2006)

QUASE sempre (FACULDADE DE FILOSOFIA, LETRAS E CIÊNCIAS HUMANAS, 2006)

A colheita manual é atualmente realizada na QUASE totalidade das propriedades citrícolas nacionais, (ESCOLA SUPERIOR DE AGRICULTURA "LUIZ DE QUEIROZ”, 2006)

As amostras de própolis analisadas apresentaram resultados, na QUASE totalidade, de acordo com os limites estabelecidos pelo Ministério da Agricultura. (INSTITUTO DE QUÍMICA, 2006)

a QUASE todos os estágios da cicatrização (FACULDADE DE MEDICINA, 2006) 
ao longo de QUASE toda a costa leste do Brasil, (INSTITUTO DE BIOCIÊNCIAS, 2006)

e QUASE todas as sentenças contrárias (FACULDADE DE DIREITO, 2006)

fenômeno que se verificou em QUASE toda civilização ocidental, (FACULDADE DE DIREITO, 2006)

são QUASE todos constituídos (ESCOLA POLITÉCNICA, 2006)

O microcosmo de Vilamaninhos é composto por indivíduos iletrados em sua QUASE totalidade. (FACULDADE DE FILOSOFIA, LETRAS E CIÊNCIAS HUMANAS, 2006)

Com base nos resultados de Eh e $\mathrm{pH}$ foi verificado que a QUASE totalidade das amostras se situam no campo de estabilidade do Hg elementar (ESCOLA SUPERIOR DE AGRICULTURA “LUIZ DE QUEIROZ”, 2006)

para QUASE todos os passeios (INSTITUTO DE MATEMÁTICA E ESTATÍSTICA, 2006)

QUASE todos os cenários (INSTITUTO DE MATEMÁTICA E ESTATÍSTICA, 2006)

QUASE todos esses traços (ESCOLA DE ENGENHARIA DE SÃO CARLOS, 2006)

A análise de vinte e quatro pronunciamentos, recuperados na QUASE totalidade em fontes primárias, (FACULDADE DE FILOSOFIA, LETRAS E CIÊNCIAS HUMANAS, 2006)

Como conclusão, poder-se-ia postular que a política fiscal implementada o Brasil durante QUASE toda sua história como Nação indepenedente, oscila entre períodos de autêntica sustentabilidade (FACULDADE DE ECONOMIA, ADMINISTRAÇÃO E CONTABILIDADE, 2006)

QUASE todos os pacientes (FACULDADE DE ODONTOLOGIA, 2006)

a QUASE totalidade das necessidades foi considerada "importante" (ESCOLA DE ENFERMAGEM, 2006)

QUASE um quarto da evolução da exportação (ESCOLA SUPERIOR DE AGRICULTURA “LUIZ DE QUEIROZ”, 2006)

QUASE a metade dos profissionais de saúde apresentou os sentimentos de compaixão e tristeza frente ao paciente usuário de drogas. (ESCOLA DE ENFERMAGEM, 2006)

Nos estudos in vivo do acúmulo de PpIX em pele de camundongo sem pêlo foi observado que a quantidade de PpIX induzida pelo 5-ALA liberado da microemulsão foi QUASE 3 vezes superior àquela induzida pelo fármaco incorporado em outras formulações encontradas na literatura. (FACULDADE DE CIÊNCIAS FARMACÊUTICAS DE RIBEIRÃO PRETO, 2006)

QUASE $130 \mathrm{Kg}$ (ESCOLA POLITÉCNICA, 2006) 
Do selênio colocado na composição do vidro, QUASE $80 \%$ é vaporizado ou reage formando selênio incolor. (ESCOLA POLITÉCNICA, 2006)

QUASE 75\% dos itens avaliados (FACULDADE DE FILOSOFIA, LETRAS E CIÊNCIAS HUMANAS, 2006)

As bandeiras, que percorreram a região dessa Província, QUASE só falavam o tupi. (FACULDADE DE FILOSOFIA, LETRAS E CIÊNCIAS HUMANAS, 2006)

diminuição de QUASE um terço do valor inicial. (FACULDADE DE ODONTOLOGIA, 2006)

foi QUASE o dobro (ESCOLA DE ENGENHARIA DE SÃO CARLOS, 2006)

QUASE nove mil de resíduos domiciliares. (FACULDADE DE ARQUITETURA E URBANISMO, 2006)

QUASE 6 bilhões de reais (FACULDADE DE MEDICINA, 2006)

QUASE metade da amostra (FACULDADE DE ODONTOLOGIA, 2006)

QUASE dez anos (FACULDADE DE FILOSOFIA, LETRAS E CIÊNCIAS HUMANAS, 2006)

QUASE dois séculos (FACULDADE DE FILOSOFIA, LETRAS E CIÊNCIAS HUMANAS, 2006)

em QUASE 150 anos (FACULDADE DE ARQUITETURA E URBANISMO, 2006)

QUASE três anos (FACULDADE DE FILOSOFIA, LETRAS E CIÊNCIAS HUMANAS, 2006)

QUASE três séculos (MUSEU DE ARQUEOLOGIA E ETNOLOGIA, 2006)

QUASE três anos (INSTITUTO DE FÍSICA, 2006)

Leite, verduras e frutas são destinadas QUASE exclusivamente para as crianças pequenas. (INSTITUTO DE QUÍMICA, 2006)

Para tanto, nossa análise toma não apenas a longa tradição de estudos whitmanianos, que atualmente têm se dedicado à revisão histórica de Leaves of Grass centrada QUASE que exclusivamente na experiência social norte-americana, mas a própria tradição crítica brasileira, (FACULDADE DE FILOSOFIA, LETRAS E CIÊNCIAS HUMANAS, 2006)

é constituído QUASE exclusivamente por hélices-a. (INSTITUTO DE FÍSICA, 2006)

Um total de 35.995 espécimes foram capturados na várzea do rio Freio, representado QUASE que exclusivamente por Nyssomyia neivai, (FACULDADE DE SAÚDE PÚBLICA, 2006)

as chuvas e os rios abastecem os lençóis freáticos causando inundações; e a alimentação do rebanho baseia-se QUASE que integralmente em pastagens nativas. (FACULDADE DE FILOSOFIA, LETRAS E CIÊNCIAS HUMANAS, 2006) 
Recém saída de um período conturbado que, apesar de todas as regulamentações, pretensa proteção governamental, e até bom potencial mercadológico QUASE finaliza em morte precoce, tem sua redenção anunciada. (ESCOLA DE ENGENHARIA DE SÃO CARLOS, 2006)

A influência dessas espécies decresce em direção ao norte, até QUASE desaparecer na região da Ilha de São Sebastião. (INSTITUTO OCEANOGRÁFICO, 2006)

concordância QUASE perfeita no grupo de glaucoma moderado $(\mathrm{k}=0,88 ; \mathrm{p}<0.001)$. (FACULDADE DE MEDICINA, 2006)

QUASE-estacionário (INSTITUTO OCEANOGRÁFICO, 2006)

QUASE artesanal. (INSTITUTO DE QUÍMICA, 2006)

No passado, as empresas claramente optavam pelos plásticos chamados de termofixos, que hoje estão QUASE esquecidos ou obsoletos (principalmente devido aos processamentos mais custosos e/ou mais lentos). (ESCOLA POLITÉCNICA, 2006)

QUASE circulares (INSTITUTO DE ASTRONOMIA, GEOFÍSICA E CIÊNCIAS ATMOSFÉRICAS, 2006)

Por se tratar de pesquisa QUASE inédita, foi necessária recorrer a artigos de jornal de periódicos, bem como as entrevistas especialmente realizadas com amadores de teatro do Estado de São Paulo em atividade no período abordado. (ESCOLA DE COMUNICAÇÃO E ARTES, 2006)

limite QUASE-unidimensional. (INSTITUTO DE FÍSICA, 2006)

de forma QUASE regular (INSTITUTO DE QUÍMICA, 2006)

e QUASE imediato declínio (FACULDADE DE EDUCAÇÃO INSTITUTO DE FÍSICA, 2006)

QUASE circulares. (INSTITUTO DE ASTRONOMIA, GEOINSTITUTO DE FÍSICA E CIÊNCIAS ATMOSFÉRICAS, 2006)

QUASE-degenerados (INSTITUTO DE FÍSICA, 2006)

QUASE-estacionárias (INSTITUTO DE MATEMÁTICA E ESTATÍSTICA, 2006)

até concordância QUASE perfeita entre o método e os especialistas, (FACULDADE DE MEDICINA, 2006)

QUASE completas (FACULDADE DE FILOSOFIA, LETRAS E CIÊNCIAS HUMANAS DE RIBEIRÃO PRETOS, 2006)

QUASE-sinóticas (INSTITUTO OCEANOGRÁFICO, 2006)

QUASE-geostrófico (INSTITUTO OCEANOGRÁFICO, 2006)

QUASE-estacionária (INSTITUTO OCEANOGRÁFICO, 2006)

dois QUASE-randomizados (INSTITUTO DE PSICOLOGIA, 2006) 
Quanto aos sindicatos, teriam papel complemen tar, em assuntos nos quais a harmonia é QUASE que inatingível, como, por exemplo, nas discussões acerca de reajustes salariais. (FACULDADE DE DIREITO, 2006)

QUASE-elástico (INSTITUTO DE FÍSICA, 2006)

QUASE-horárias (INSTITUTO OCEANOGRÁFICO, 2006)

é QUASE impossível exaurir um tema (ESCOLA DE COMUNICAÇÃO E ARTES, 2006)

o número de Strouhal permanece QUASE constante e é independente do número de Reynolds, (ESCOLA DE ENGENHARIA DE SÃO CARLOS, 2006)

forma QUASE exclusiva (FACULDADE DE FILOSOFIA, LETRAS E CIÊNCIAS HUMANAS, 2006)

QUASE inatingível (FACULDADE DE FILOSOFIA, LETRAS E CIÊNCIAS HUMANAS, 2006)

A concepção de espaço que resulta daí é de um espaço "QUASE pura lógica" que serve à reprodução do Estado e do capitalismo. (FACULDADE DE FILOSOFIA, LETRAS E CIÊNCIAS HUMANAS, 2006)

QUASE zero-dimensionais (...) QUASE zero-dimensionais (INSTITUTO DE FÍSICA, 2006)

QUASE-estática (ESCOLA POLITÉCNICA, 2006)

QUASE-estáticos (ESCOLA DE ENGENHARIA DE SÃO CARLOS, 2006)

QUASE-geostrófico (INSTITUTO OCEANOGRÁFICO, 2006)

QUASE-estacionários. (OCENOGRÁFICO, 2006)

QUASE estáticos QUASE estáticos (ESCOLA DE ENGENHARIA DE SÃO CARLOS, 2006)

QUASE-experimental (ESCOLA DE ENFERMAGEM, 2006)

Assim como auxiliar no controle de qualidade, principalmente em indústrias exportadoras que almejam expansão de mercado, onde essa prática é QUASE uma imposição no contexto do comércio internacional de produtos pecuários "in natura" e processados. (ESCOLA SUPERIOR DE AGRICULTURA "LUIZ DE QUEIROZ", 2006)

o horizonte de superfície da toposseqüência, pequeno número de poros complexos de diâmetro equivalente superior a $1000 \mathrm{~m}$ ocupou QUASE a área total da imagem, (ESCOLA SUPERIOR DE AGRICULTURA “LUIZ DE QUEIROZ”, 2006)

em uma diminuição ou QUASE ausência da presença (FACULDADE DE CIÊNCIAS FARMACÊUTICAS DE RIBEIRÃO PRETO, 2006)

a QUASE onipresença da indústria (ESCOLA DE COMUNICAÇÃO E ARTES, 2006) 
estilo do "QUASE-experimento"182 (FACULDADE DE ECONOMIA, ADMINISTRAÇÃ̃ E CONTABILIDADE, 2006)

uma relação de QUASE equivalência (FACULDADE DE SAÚDE PÚBLICA, 2006)

o seu diagnóstico QUASE nunca é de certeza. (INSTITUTO DE BIOCIÊNCIAS, 2006)

enquanto que pacientes submetidos à técnica de BELL 12 tiveram pouco ou QUASE nenhum desconforto (FACULDADE DE ODONTOLOGIA, 2006)

destaca-se o Parque Estadual da Cantareira coberto, em QUASE sua totalidade, pela floresta nativa. (FACULDADE DE FILOSOFIA, LETRAS E CIÊNCIAS HUMANAS, 2006)

uma com QUASE toda a área em estágio avançado de urbanização (FACULDADE DE FILOSOFIA, LETRAS E CIÊNCIAS HUMANAS, 2006)

QUASE sempre (FACULDADE DE CIÊNCIAS FARMACÊUTICAS DE RIBEIRÃO PRETO, 2006)

a QUASE todas as fisionomias de cerrado, (INSTITUTO DE BIOCIÊNCIAS, 2006)

De QUASE todas as espécies (FACULDADE DE MEDICINA VETERINÁRIA E ZOOTECNIA, 2006)

abrangendo QUASE toda a distribuição conhecida da espécie. (INSTITUTO DE BIOCIÊNCIAS, 2006)

em QUASE todos os mamíferos (FACULDADE DE FILOSOFIA, LETRAS E CIÊNCIAS HUMANAS DE RIBEIRÃO PRETOS, 2005)

QUASE sempre (FACULDADE DE ARQUITETURA E URBANISMO, 2005)

que toma QUASE todas as decisões estratégicas (ESCOLA SUPERIOR DE AGRICULTURA “LUIZ DE QUEIROZ”, 2005)

QUASE todos fortemente impregnados (ESCOLA DE COMUNICAÇÃO E ARTES, 2005)

QUASE sempre, (INSTITUTO DE PSICOLOGIA, 2005)

aumento de QUASE a totalidade de profissionais (FACULDADE DE FILOSOFIA, LETRAS E CIÊNCIAS HUMANAS DE RIBEIRÃO PRETOS, 2005)

QUASE todos os pacientes avaliados (FACULDADE DE ODONTOLOGIA, 2005)

em QUASE todos os corpos-de-prova (FACULDADE DE ODONTOLOGIA, 2005)

QUASE sempre (FACULDADE DE DIREITO, 2005)

em QUASE todas as situações. (ESCOLA POLITÉCNICA, 2005)

$\overline{182}$ Foram quatro ocorrências deste dado neste resumo. 
QUASE sempre (INSTITUTO DE GEOCIÊNCIAS, 2005)

em QUASE todas as regiões (ESCOLA SUPERIOR DE AGRICULTURA "LUIZ DE QUEIROZ”, 2005)

QUASE sempre; QUASE sempre (INSTITUTO DE BIOCIÊNCIAS, 2005)

durante QUASE todo CP (FACULDADE DE MEDICINA VETERINÁRIA E ZOOTECNIA, 2005)

por QUASE todos os países (ESCOLA DE COMUNICAÇÃO E ARTES, 2005)

acesso a QUASE todos os tipos (INSTITUTO DE MATEMÁTICA E ESTATÍSTICA, 2005)

QUASE sempre (FACULDADE DE DIREITO, 2005)

QUASE sempre (ESCOLA SUPERIOR DE AGRICULTURA “LUIZ DE QUEIROZ”, 2005)

em QUASE todos os valores (INSTITUTO DE QUÍMICA, 2005)

durante QUASE todo período de estudo (ESCOLA DE ENGENHARIA DE SÃO CARLOS, 2005)

a remoção QUASE total de nitrato (ESCOLA DE ENGENHARIA DE SÃO CARLOS, 2005)

Muitos projetos, senão a QUASE totalidade, são gerenciados sem que haja o adequado uso de metodologias (ESCOLA POLITÉCNICA, 2005)

conceito adotado por QUASE que a totalidade das montadoras. (ESCOLA POLITÉCNICA, 2005)

Em QUASE todas as localidades do mundo (FACULDADE DE CIÊNCIAS FARMACÊUTICAS DE RIBEIRÃO PRETO, 2005)

em QUASE todos os estados do Brasil, (FACULDADE DE MEDICINA VETERINÁRIA E ZOOTECNIA, 2005)

sendo que a QUASE totalidade dos mesmos apresentou teor médio (INSTITUTO DE GEOCIÊNCIAS, 2005)

geograficamente distribuído por QUASE todo o Brasil, (FACULDADE DE MEDICINA VETERINÁRIA E ZOOTECNIA, 2005)

QUASE sempre (ESCOLA DE ENFERMAGEM, 2005)

QUASE a totalidade $(92,8 \%)$ não era cadastrada (ESCOLA DE ENFERMAGEM, 2005)

QUASE sempre (FACULDADE DE ARQUITETURA E URBANISMO, 2005)

aumento de QUASE 100\% (FACULDADE DE FILOSOFIA, LETRAS E CIÊNCIAS HUMANAS DE RIBEIRÃO PRETO, 2005) 
QUASE 400 questionários (ESCOLA DE COMUNICAÇÃO E ARTES, 2005)

QUASE 400 projetos comunitários (ESCOLA DE COMUNICAÇÃO E ARTES, 2005)

de QUASE cinco dezenas de edições (ESCOLA DE COMUNICAÇÃO E ARTES, 2005)

Os título vacinais tenderam a baixar rapidamente nos meses subsequentes à vacinação, sendo QUASE nulos após seis meses das revacinações. (FACULDADE DE MEDICINA VETERINÁRIA E ZOOTECNIA, 2005)

a QUASE 200 mmHg. (FACULDADE DE MEDICINA, 2005)

aumentou em QUASE três vezes (INSTITUTO DE BIOCIÊNCIAS, 2005)

QUASE 1/3 da população (FACULDADE DE ODONTOLOGIA, 2005)

Afinal, a derrota de Bar Kokhva não apenas frustrou a esperança de reconquista de Jerusalém, como também acabou por selar a diáspora do povo judeu, que duraria por QUASE dois milênios. (FACULDADE DE FILOSOFIA, LETRAS E CIÊNCIAS HUMANAS, 2005)

durante QUASE 30 anos de (FACULDADE DE EDUCAÇÃO, 2005)

QUASE um século (FACULDADE DE FILOSOFIA, LETRAS E CIÊNCIAS HUMANAS, 2005)

Partindo do pressuposto que o IPHAN estabeleceu um paradigma teórico e técnico na restauração desse tipo arquitetônico, o trabalho verifica a extensão da permanência e, inversamente, do desaparecimento do paradigma naquelas seis casas, ao longo dos QUASE cinquienta anos abrangidos pelo estudo. (FACULDADE DE ARQUITETURA E URBANISMO, 2005)

há QUASE quarenta anos (FACULDADE DE DIREITO, 2005)

QUASE 50 anos (FACULDADE DE ECONOMIA, ADMINISTRAÇÃO E CONTABILIDADE, 2005)

A partir das condições especiais em que vivem os índios há QUASE uma década, numa aldeia de casas de alvenaria, com energia elétrica e água encanada, foi buscado perceber como se dá a conexão entre sua cultura primitiva e a busca por novos significados, com a inserção do grupo em uma Sociedade Industrial, Capitalista marcada pela força da Indústria Cultural e seus difusores, os Meios de Comunicação de Massa, mais especificamente a televisão como sedutor instrumento de indução ao consumo. (ESCOLA DE COMUNICAÇÃ̃ E ARTES, 2005)

Enquanto o usuário de computador tem sua atenção completamente voltada ao uso do computador, o motorista, em sua tarefa de guiar o veículo, dedica seus recursos QUASE que totalmente ao trânsito ou ao ato de dirigir. (ESCOLA POLITÉCNICA, 2005) 
Se durante a antiguidade as mudanças eram atribuídas aos desígnios divinos, a história iniciada, especialmente a partir da chamada modernidade, atendeu, QUASE que integralmente, aos ditames da vontade humana. (FACULDADE DE DIREITO, 2005)

mostrou-se QUASE inteiramente heterocromático. (INSTITUTO DE BIOCIÊNCIAS, 2005)

Dentro da literatura sobre gestão de projetos, trabalhos que estudam o uso do escritório de projetos dedicam-se, QUASE que exclusivamente, a citar modelos e exemplos bem sucedidos (ESCOLA DE ENGENHARIA DE SÃO CARLOS, 2005)

se deu a partir da venda do suco de laranja concentrado e congelado, com produção destinada QUASE que exclusivamente no mercado externo. (FACULDADE DE ECONOMIA, ADMINISTRAÇÃO E CONTABILIDADE, 2005)

No último século, tais sistemas foram QUASE que exclusivamente trotados no contexto da teoria de transporte. (INSTITUTO DE FÍSICA, 2005)

são QUASE completamente desconhecidos no litoral brasileiro (INSTITUTO DE BIOCIÊNCIAS, 2005)

O país adotou e incentivou um modelo baseado QUASE que totalmente no modal rodoviário. (ESCOLA POLITÉCNICA, 2005)

o perfil do brasileiro é QUASE totalmente diferente do perfil norte-americano, exceção feita a apenas quatro pontos (FACULDADE DE ODONTOLOGIA, 2005)

Estes dados mostram que o ensino de ciências que se apresenta hoje nas escolas, centrado QUASE que exclusivamente no livro didático (FACULDADE DE EDUCAÇÃO, 2005)

Os minérios friável e compacto consistem QUASE que totalmente de 'Fe IND.2' $\mathrm{O}$ IND.3', (INSTITUTO DE GEOCIÊNCIAS, 2005)

QUASE-experimental QUASE-experimental (ESCOLA DE ENFERMAGEM, 2005)

QUASE certa (INSTITUTO DE MATEMÁTICA E ESTATÍSTICA, 2005)

Determinam-se os chamados Modos QUASE-Normais (MQNs) (INSTITUTO DE FÍSICA, 2005)

QUASE-experimental, (ESCOLA DE ENFERMAGEM, 2005)

QUASE-periódicos. (INSTITUTO DE FÍSICA, 2005)

QUASE parada (ESCOLA POLITÉCNICA, 2005)

Publicadas QUASE diariamente (FACULDADE DE ARQUITETURA DE URBANISMO, 2005)

QUASE equivalentes (INSTITUTO DE BIOCIÊNCIAS, 2005)

do tipo QUASE experimental. (ESCOLA DE ENFERMAGEM, 2005) 
QUASE-experimental (ESCOLA DE ENFERMAGEM, 2005)

para existência de soluções QUASE e assintoticamente QUASE periódicas (INSTITUTO DE MATEMÁTICA E ESTATÍSTICA, 2005)

na forma QUASE linear (ESCOLA DE ENGENHARIA DE SÃO CARLOS, 2005)

elo QUASE perdido (ESCOLA DE COMUNICAÇÃO E ARTES, 2005)

uma relação "QUASE" linear (INSTITUTO DE FÍSICA, 2005)

É possível adotá-las de maneira QUASE que integral, ainda que sejam necessárias adaptações (FACULDADE DE ECONOMIA, ADMINISTRAÇÃO E CONTABILIDADE, 2005)

esta técnica recebe o nome de simulação QUASE Monte Carlo (FACULDADE DE ECONOMIA, ADMINISTRAÇÃO E CONTABILIDADE, 2005)

uma 'QUASE-metodologia' (FACULDADE DE EDUCAÇÃO, 2005)

do canal do QUASE-dêuteron; do canal do QUASE-dêuteron; mecanismo do QUASEdêuteron (INSTITUTO DE FÍSICA, 2005)

pela QUASE ausência de sítios (INSTITUTO DE QUÍMICA, 2005)

Embora QUASE não tenha sido mobilizado cobre para fora das colunas (ESCOLA SUPERIOR DE AGRICULTURA “LUIZ DE QUEIROZ”, 2005)

não existe QUASE nenhuma literatura sobre ela em português. (ESCOLA POLITÉCNICA, 2005)

Isto se deve especialmente a um trabalho de equipe, que vem se desenvolvendo a QUASE 30 anos (INSTITUTO DE BIOCIÊNCIAS, 2005)

Esse período QUASE coincidiu com o surgimento de cianobactérias (INSTITUTO DE BIOCIÊNCIAS, 2004)

Ao longo dos mais de 80 anos de vigência do Código Civil de 1916 (onde era expressamente previsto - artigos 1.158 e seguintes), QUASE não foi estudado, (FACULDADE DE DIREITO, 2004)

Para atingir esse objetivo, tomamos por base os conceitos teóricos de Eco (2007) sobre a tradução que afirma que quando se traduz nunca se diz a mesma coisa, mas QUASE e Berman (FACULDADE DE FILOSOFIA, LETRAS E CIÊNCIAS HUMANAS, 2002)

na expressão de QUASE todos os genes relógios (INSTITUTO DE BIOMÉDICAS, 2001)

Em um primeiro momento o documento mostra, QUASE que passo a passo, todas as angustias de um estudante universitário, (ESCOLA DE ENGENHARIA DE SÃO CARLOS, 1998) 


\section{ANEXO II: Critérios de correção para as dissertações de candidatos ao vestibular da Fuvest}

Disponíveis em: <www.fuvest.br>. Data de acesso: 25/10/2013.

\section{Tipo de texto e abordagem do tema}

Verifica-se aqui se o texto do candidato configura-se como uma dissertação e se atende ao tema proposto. Pressupõe-se, então, que o candidato demonstre a habilidade de compreender a proposta de redação e, quando esta contiver uma coletânea, que ele se revele capaz de ler e de relacionar adequadamente os trechos que a integram. A simples paráfrase da coletânea, da proposta e/ou das instruções não é, em princípio, um recurso recomendável para o desenvolvimento adequado do tema. A elaboração de um texto que não seja dissertativo ou a fuga completa ao tema proposto farão com que a redação não seja objeto de avaliação em qualquer outro de seus aspectos, recebendo, portanto, nota zero em sua totalidade. No que diz respeito ao desenvolvimento, verificar-se-á, além da efetiva progressão temática, também a capacidade crítico argumentativa que a redação revele.

\section{Estrutura}

Avaliam-se aqui, conjuntamente, os aspectos de coesão textual (nas frases, períodos e parágrafos) e de coerência das ideias. O grau de coerência reflete a capacidade do candidato para relacionar os argumentos e organizá-los de forma a deles extrair conclusões apropriadas e, também, sua habilidade para o planejamento e a construção significativa do texto. Serão considerados aspectos negativos a cópia ou a simples transposição de elementos da proposta, bem como a presença de contradições entre frases ou parágrafos, a falta de encadeamento das ideias, a circularidade ou quebra da progressão argumentativa, a falta de conclusão ou a presença de conclusões que não decorram do que foi previamente exposto. Serão tidos também como fatos negativos referentes à coesão, entre outros, o estabelecimento de relações semânticas impróprias entre palavras e expressões, assim como o uso inadequado de conectivos.

\section{Expressão}

Avaliam-se nesse item o domínio do padrão culto escrito da língua e a clareza na expressão das ideias. Serão examinados aspectos gramaticais como ortografia, morfologia, sintaxe e pontuação. Espera-se que o candidato revele competência para expor com precisão os argumentos selecionados para a defesa do ponto de vista adotado e, também, que demonstre capacidade de escolher e utilizar expressivamente o vocabulário, evitando o uso abusivo de clichês ou frases feitas. 